Nevada

Environmental

Restoration

Project

\title{
Closure Report for Corrective Action Unit 516: Septic Systems and Discharge Points Nevada Test Site, Nevada
}

Controlled Copy No.:

Revision: 0

April 2007

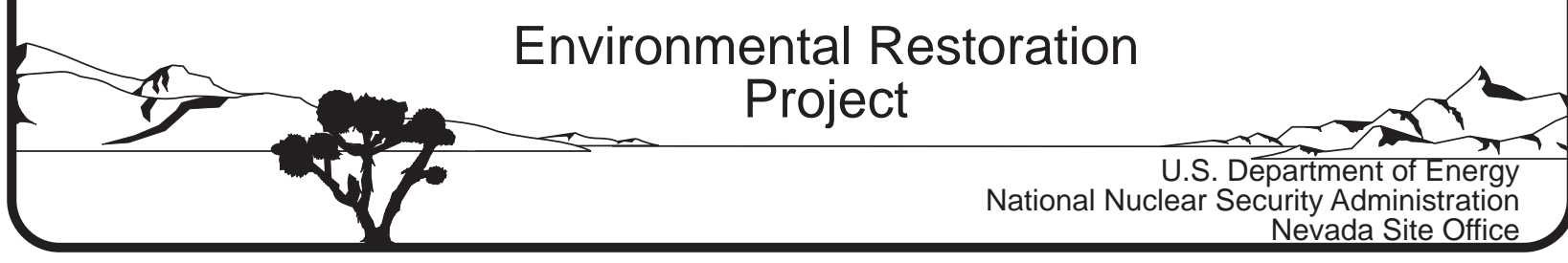




\section{DISCLAIMER}

Reference herein to any specific commercial product, process, or service by trade name, trademark, manufacturer, or otherwise, does not necessarily constitute or imply its endorsement, recommendation, or favoring by the United States Government or any agency thereof or its contractors or subcontractors.

This report has been reproduced directly from the best available copy.

Available for sale to the public from:

U.S. Department of Commerce

National Technical Information Service

5285 Port Royal Road

Springfield, VA 22161-0002

Telephone: (800) 553-6847

Fax: (703) 605-6900

E-mail: orders@ntis.gov

Online ordering: http://www.ntis.gov/ordering.htm

Available electronically at http://www.osti.gov/bridge.

Available for a processing fee to the U.S. Department of Energy and its contractors, in paper, from:

U.S. Department of Energy

Office of Scientific and Technical Information

P.O. Box 62

Oak Ridge, TN 37831-0062

Telephone: (865) 576-8401

Fax: (865) 576-5728

E-mail: reports@adonis.osti.gov 


\title{
CLOSURE REPORT FOR CORRECTIVE ACTION UNIT 516: SEPTIC SYSTEMS AND DISCHARGE POINTS NEVADA TEST SITE, NEVADA
}

\author{
U.S. Department of Energy \\ National Nuclear Security Administration \\ Nevada Site Office \\ Las Vegas, Nevada
}

Controlled Copy No.

Revision: 0

April 2007 
THIS PAGE INTENTIONALLY LEFT BLANK 


\section{CLOSURE REPORT FOR CORRECTIVE ACTION UNIT 516: SEPTIC SYSTEMS AND DISCHARGE POINTS NEVADA TEST SITE, NEVADA}

Approved By: SIGNATURE APPROVED

Date: $\underline{04 / 03 / 2007}$

Kevin J. Cabble,

Federal Sub-Project Director

Industrial Sites Sub-Project

Approved By: SIGNATURE APPROVED

Date: $\underline{04 / 03 / 2007}$

John B. Jones,

Acting Federal Project Director

Environmental Restoration Project 
THIS PAGE INTENTIONALLY LEFT BLANK 


\section{TABLE OF CONTENTS}

ACRONYMS AND ABBREVIATIONS ........................................................................ vii

EXECUTIVE SUMMARY ……………........................................................................... ix

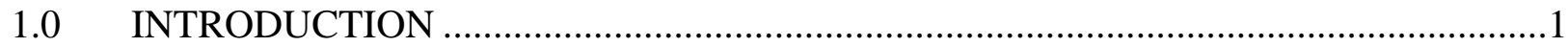

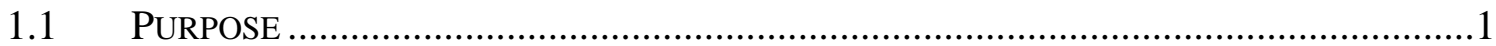

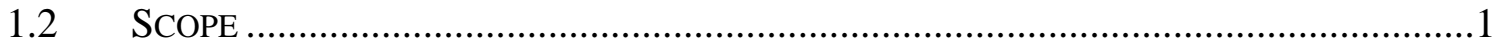

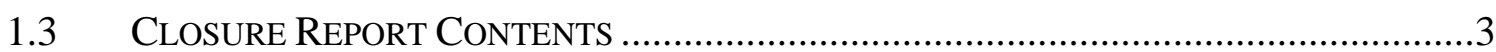

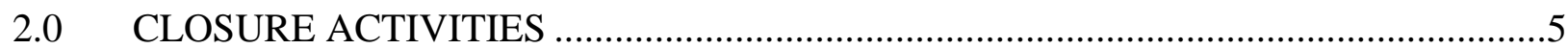

2.1 DESCRIPTION OF CORRECTIVE ACTION ACTIVITIES ...............................................

2.1.1 CAS 03-59-01, Bldg 3C-36 Septic System.................................................

2.1.2 CAS 03-59-02, Bldg 3C-45 Septic System................................................

2.1.3 CAS 06-51-01, Sump and Piping, and CAS 06-51-03, Clean Out Box and Piping .........................................................................................

2.2 Deviations From Corrective Action Plan as ApPRoved ..............................10

2.3 CoRRECTIVE Action SCHEdULE AS CoMPLETED .................................................10

2.4 SITE PLAN / SURVEY PLAT ..............................................................................10

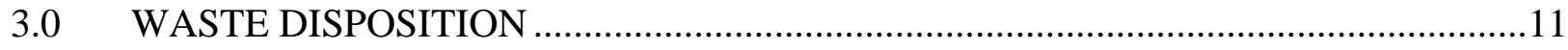

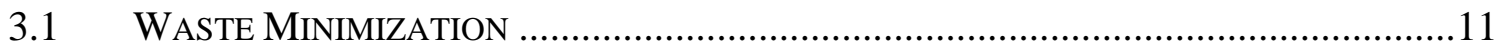

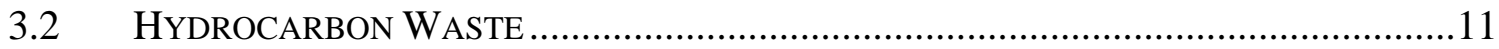

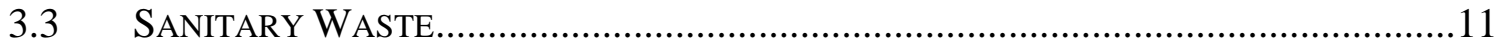

4.0 CLOSURE VERIFICATION RESULTS ...............................................................13

$4.1 \quad$ DATA QUALITY ASSESSMENT ………………..............................................15

4.1.1 Quality Assurance/Quality Control Procedures..........................................15

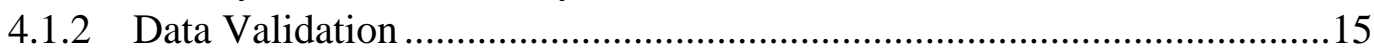

4.1.3 Conceptual Site Model.......................................................................15

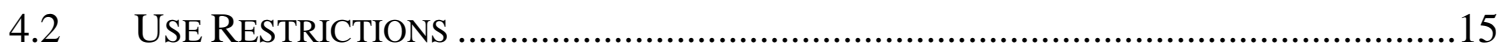

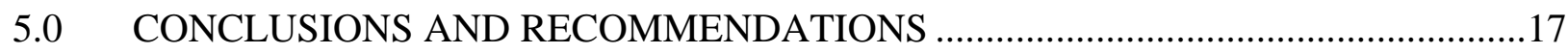

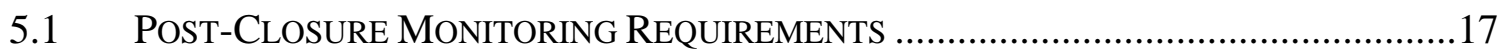

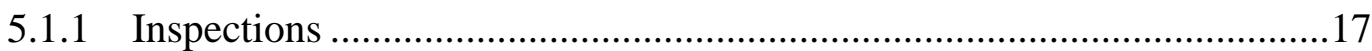

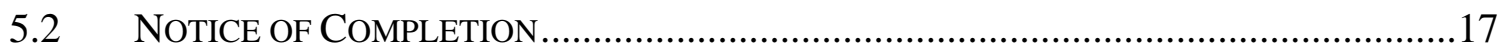

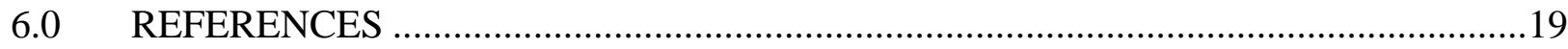

LIBRARY DISTRIBUTION LIST 


\section{FIGURES}

Figure 1. CAU 516 CORREctive Action Sites LocAtion MAP ............................................2

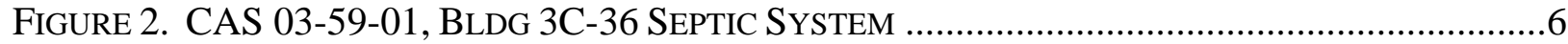

FIGURE 3. CAS 03-59-02, BLDG 3C-45 SEPTIC SYSTEM …...................................................8

Figure 4. CAS 06-51-01, SumP AND PIPING, AND CAS 06-51-03, ClEAN-OUT Box AND PIPING 9

\section{TABLES}

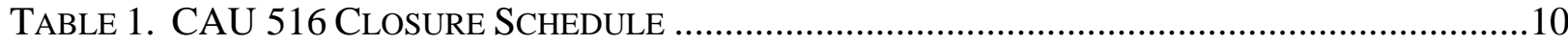

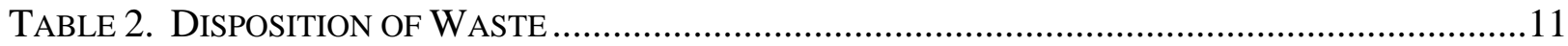

TABLE 3. VerificATION SAMPLE ANALYTICAL RESUlTS ..........................................................14

\section{APPENDICES}

ApPENDix A: $\quad$ Data Quality OBJectives

ApPendix B: $\quad$ Analytical Results

APPENDIX C: $\quad$ WASte Disposition DOCUMENTATION

APPENDIX D: $\quad$ FIELD PHOTOGRAPHS

Appendix E: $\quad$ NATional ENVIRONMENTal Policy ACt EnVIRONMENTAl EVAluation CHECKLIST 


\section{ACRONYMS AND ABBREVIATIONS}

\begin{tabular}{|c|c|}
\hline BMP & best management practice \\
\hline CADD & Corrective Action Decision Document \\
\hline CAIP & Corrective Action Investigation Plan \\
\hline CAP & Corrective Action Plan \\
\hline CAS & Corrective Action Site \\
\hline CAU & Corrective Action Unit \\
\hline $\mathrm{COC}$ & contaminant of concern \\
\hline CR & Closure Report \\
\hline DOE & U.S. Department of Energy \\
\hline DQO & data quality objective \\
\hline DRO & diesel range organics \\
\hline FFACO & Federal Facility Agreement and Consent Order \\
\hline $\mathrm{ft}$ & foot (feet) \\
\hline gal & gallon(s) \\
\hline $\mathrm{mg} / \mathrm{kg}$ & milligram(s) per kilogram \\
\hline NDEP & Nevada Division of Environmental Protection \\
\hline NEPA & National Environmental Policy Act \\
\hline NNSA/NSO & $\begin{array}{l}\text { U.S. Department of Energy, National Nuclear Security Administration Nevada } \\
\text { Site Office }\end{array}$ \\
\hline NNSA/NV & $\begin{array}{l}\text { U.S. Department of Energy, National Nuclear Security Administration Nevada } \\
\text { Operations Office }\end{array}$ \\
\hline NSTec & National Security Technologies, LLC \\
\hline NTS & Nevada Test Site \\
\hline QA/QC & Quality Assurance/Quality Control \\
\hline QAPP & Quality Assurance Project Plan \\
\hline $\mathrm{TPH}$ & total petroleum hydrocarbons \\
\hline $\mathrm{yd}^{3}$ & cubic yard(s) \\
\hline
\end{tabular}


CAU 516 Closure Report

Section: Acronyms \& Abbreviations

Revision: 0

Date: April 2007

\section{THIS PAGE INTENTIONALLY LEFT BLANK}




\section{EXECUTIVE SUMMARY}

Corrective Action Unit (CAU) 516 is located in Areas 3, 6, and 22 of the Nevada Test Site. CAU 516 is listed in the Federal Facility Agreement and Consent Order of 1996 as Septic Systems and Discharge Points, and is comprised of six Corrective Action Sites (CASs):

- CAS 03-59-01, Bldg 3C-36 Septic System

- CAS 03-59-02, Bldg 3C-45 Septic System

- $\quad$ CAS 06-51-01, Sump and Piping

- $\quad$ CAS 06-51-02, Clay Pipe and Debris

- $\quad$ CAS 06-51-03, Clean Out Box and Piping

- $\quad$ CAS 22-19-04, Vehicle Decontamination Area

The Nevada Division of Environmental Protection (NDEP)-approved corrective action alternative for CASs 06-51-02 and 22-19-04 is no further action.

The NDEP-approved corrective action alternative for CASs 03-59-01, 03-59-02, 06-51-01, and 06-51-03 is clean closure. Closure activities included removing and disposing of total petroleum hydrocarbon (TPH)-impacted septic tank contents, septic tanks, distribution/clean out boxes, and piping.

CAU 516 was closed in accordance with the NDEP-approved CAU 516 Corrective Action Plan (CAP). The closure activities specified in the CAP were based on the recommendations presented in the CAU 516 Corrective Action Decision Document (U.S. Department of Energy, National Nuclear Security Administration Nevada Site Office, 2004). This Closure Report documents CAU 516 closure activities.

During closure activities, approximately 186 tons of hydrocarbon waste in the form of TPHimpacted soil and debris, as well as 89 tons of construction debris, were generated and managed and disposed of appropriately. Waste minimization techniques, such as field screening of soil samples and the utilization of laboratory analysis to characterize and classify waste streams, were employed during the performance of closure work. 
CAU 516 Closure Report

Section: Executive Summary

Revision: 0

Date: April 2007

THIS PAGE INTENTIONALLY LEFT BLANK 


\subsection{INTRODUCTION}

Corrective Action Unit (CAU) 516 is listed in Appendix III of the Federal Facility Agreement and Consent Order (FFACO) of 1996, an agreement between the U.S. Department of Energy (DOE), the U.S. Department of Defense, and the state of Nevada, as Septic Systems and Discharge Points. CAU 516 consists of six Corrective Action Sites (CASs) located in Areas 3, 6, and 22 of the Nevada Test Site (NTS), which is located approximately 65 miles northwest of Las Vegas, Nevada. Figure 1 depicts the approximate CAS locations within the NTS. Specifically, CAU 516 includes:

- $\quad$ CAS 03-59-01, Bldg 3C-36 Septic System

- $\quad$ CAS 03-59-02, Bldg 3C-45 Septic System

- $\quad$ CAS 06-51-01, Sump and Piping

- $\quad$ CAS 06-51-02, Clay Pipe and Debris

- $\quad$ CAS 06-51-03, Clean Out Box and Piping

- $\quad$ CAS 22-19-04, Vehicle Decontamination Area

The six sites reportedly included soil, liquid, and/or debris that exceeded clean-up criteria for total petroleum hydrocarbons (TPH). Historical details of the CASs are provided in the CAU 516 Corrective Action Investigation Plan (CAIP) (U.S. Department of Energy, National Nuclear Security Administration Nevada Site Office [NNSA/NSO], 2003) and the CAU 516 Corrective Action Decision Document (CADD) (NNSA/NSO, 2004).

The corrective actions described in the CAU 516 Corrective Action Plan (CAP) (NNSA/NSO, 2005) were implemented from August 2006 through December 2006. This Closure Report (CR) has been prepared for CAU 516 in accordance with the FFACO and the Nevada Division of Environmental Protection (NDEP)-approved CAP.

\subsection{PuRPose}

The purpose of this CR is to document that the closure of CAU 516 complied with the NDEP-approved CAP closure requirements (NNSA/NSO, 2005). The closure activities specified in the CAP were based on the approved corrective action alternatives presented in the CAU 516 CADD (NNSA/NSO, 2004).

\subsection{SCOPE}

The approved closure strategy for CAU 516 was specified in the CAU 516 CADD (NNSA/NSO, 2004). The approved closure alternative for CASs 06-51-02 and 22-19-04 was no further action. The approved alternative for CASs 03-59-01, 03-59-02, 06-51-01, and 06-51-03 was clean closure. The strategy for implementing this closure was presented in the CAU 516 CAP (NNSA/NSO, 2005). 


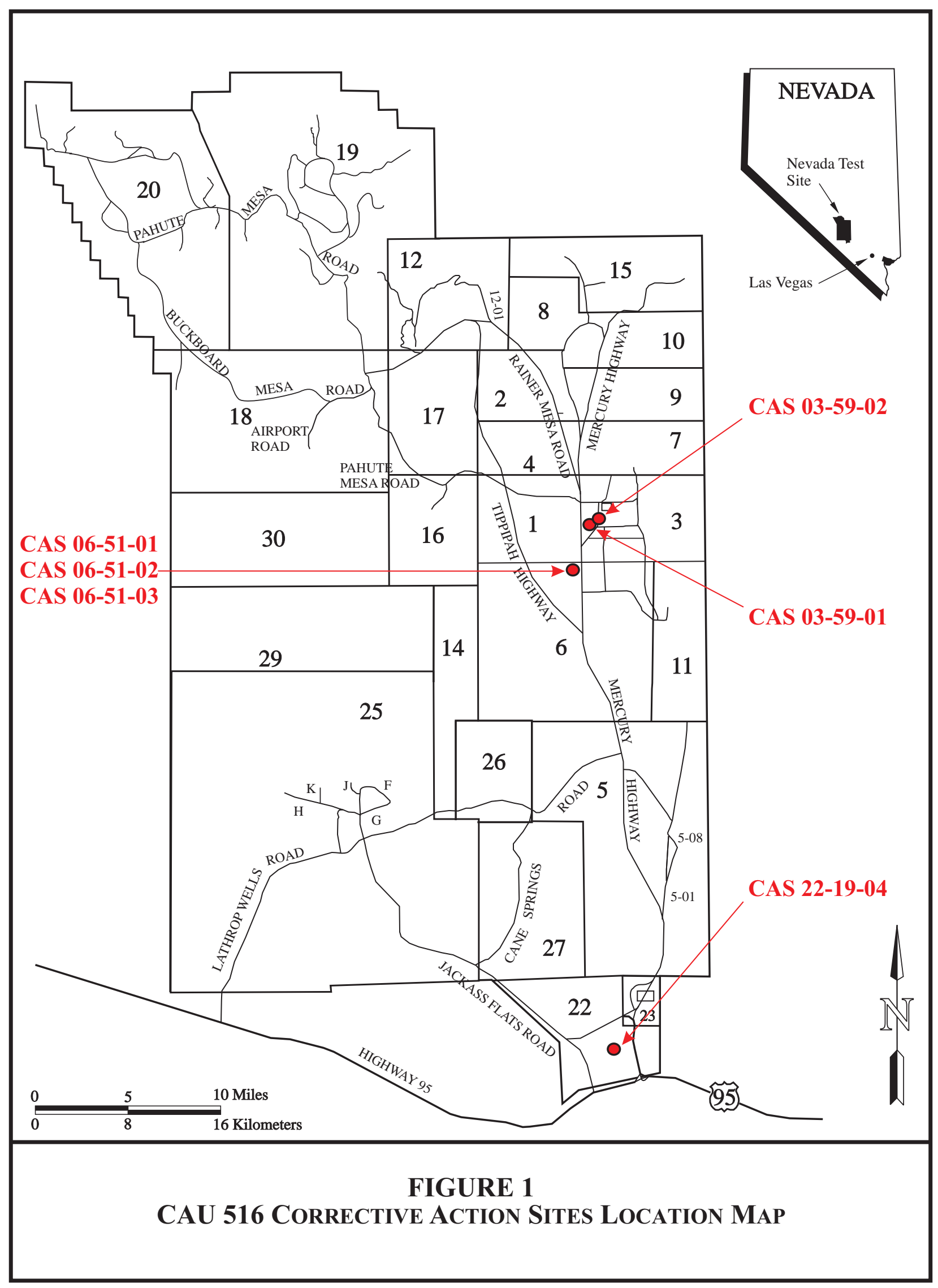


Closure activities included:

- $\quad$ Removing, solidifying, and disposing of TPH-impacted septic tank contents, and removing and disposing of the septic tank, at CAS 03-59-01

- Removing and disposing of a distribution box and 10 feet (ft) of piping at CAS 03-59-01 as a best management practice (BMP)

- Removing, solidifying, and disposing of TPH-impacted septic tank contents, and removing and disposing of the septic tank, at CAS 03-59-02

- $\quad$ Excavating and removing two dry wells at CAS 03-59-02 as a BMP

- $\quad$ Removing and disposing of TPH-impacted piping at CAS 06-51-01

- Removing and disposing of a clean out box, TPH-impacted clean out box contents, and associated piping at CAS 06-51-03

- Characterizing, excavating, and removing a 55-gallon (gal) sump discovered during fieldwork at CAS 06-51-03 as a BMP

- $\quad$ Collecting verification samples to verify clean-up criteria

- Backfilling and grading excavations to surrounding topographic contours

Detailed site-specific closure activities are presented in Section 2.0 of this report.

Data quality objectives (DQOs) were developed for the CAU 516 site characterization (NNSA/NSO, 2003) and are included in Appendix A of this report. Site closure was verified through inspections, sampling, observations, and documentation of waste disposal.

\subsection{Closure Report Contents}

This CR includes the following sections:

- $\quad$ Section 1.0, “Introduction,” presents the purpose, general scope, and an overview of report contents.

- $\quad$ Section 2.0, “Closure Activities,” describes the corrective actions completed, any deviations from the CAP, and the general closure schedule.

- $\quad$ Section 3.0, "Waste Disposition,” describes the wastes generated and documents waste disposition.

- $\quad$ Section 4.0, “Closure Verification Results,” describes the testing, inspections, and other measures used to confirm the completion of the corrective actions and the quality of results.

- $\quad$ Section 5.0, "Conclusions and Recommendations," describes the results, completion of implementation of the CAP, and the post-closure monitoring requirements.

- $\quad$ Section 6.0, "References," lists the supporting documents. 
The appendices include relevant supporting documents:

- Appendix A, “Data Quality Objectives,” presents the DQOs developed in the CAU 516 CAIP (NNSA/NSO, 2003).

- Appendix B, “Analytical Results,” presents the summary analytical results for the soil verification samples collected at CASs 03-59-01, 03-59-02, 06-51-01, and 06-51-03.

- Appendix C, "Waste Disposition Documentation,” contains copies of the load verification forms and recycling forms.

- Appendix D, "Field Photographs," contains photographs of the CASs taken prior to, during, and after closure activities.

- $\quad$ Appendix E, "National Environmental Policy Act (NEPA) Environmental Evaluation Checklist," includes the checklist evaluating the environmental impact of site closure activities. 


\subsection{CLOSURE ACTIVITIES}

This section of the CR details the specific activities involved in the closure of CAU 516.

\subsection{Description of Corrective Action Activities}

Closure of CAU 516 was completed by the National Security Technologies, LLC (NSTec) Environmental Restoration Project using the approved CAP for CAU 516 (NNSA/NSO, 2005). The CAP was based on the recommendations presented in the CAU 516 CADD (NNSA/NSO, 2004).

Prior to beginning closure activities, the following pre-field activities were completed:

- $\quad$ Preparation of a NEPA Checklist

- $\quad$ Preparation of a Field Management Plan for CAU 516 (NSTec, 2006a)

- $\quad$ Preparation of a Site-Specific Health And Safety Plan for closure activities at CAU 516, (NSTec, 2006b)

- $\quad$ Preparation of the work packages to control work

- $\quad$ Preparation of Real Estate/Operations Permits to authorize the work

- Utility surveys to ensure that all fieldwork would be conducted safely and without disruption of NTS infrastructure

Closure activities began on August 4, 2006, and were completed on December 14, 2006. The following sections detail the closure activities implemented for CAU 516.

\subsubsection{CAS 03-59-01, Bldg 3C-36 Septic System}

Figure 2 shows the site plan for CAS 03-59-01, which is located in the former Area 3 Camp south of the 3-01 Road and west of the Blowout Preventer Shop bay structure. The site consisted of a septic tank, distribution box, leachfield, and associated piping that supported the operation of Building 3C-36. Results of the site characterization reported TPH diesel range organics (DRO) as the only contaminant of concern (COC), which were present in the material contained within the septic tank (NNSA/NSO, 2004). In total, the influent and effluent chambers of the septic tank contained approximately 1,500 gal of liquid and solid waste.

The CAS was clean closed by removing and solidifying the septic tank contents, removing the concrete septic tank, and disposing of the tank and tank contents at the Area 6 Hydrocarbon Landfill. As a BMP, the distribution box and $10 \mathrm{ft}$ of associated piping were also removed and disposed of at the Area 9 U10c Sanitary Landfill as construction debris. Field screening was performed on samples taken from the bottom and base of the sidewalls of the excavation. Additional material was removed accordingly. Upon the receipt of verification sample analytical results below action levels (see Section 4.0), the excavation was backfilled with native material from an approved borrow source and graded to the approximate surrounding topographic contours. 


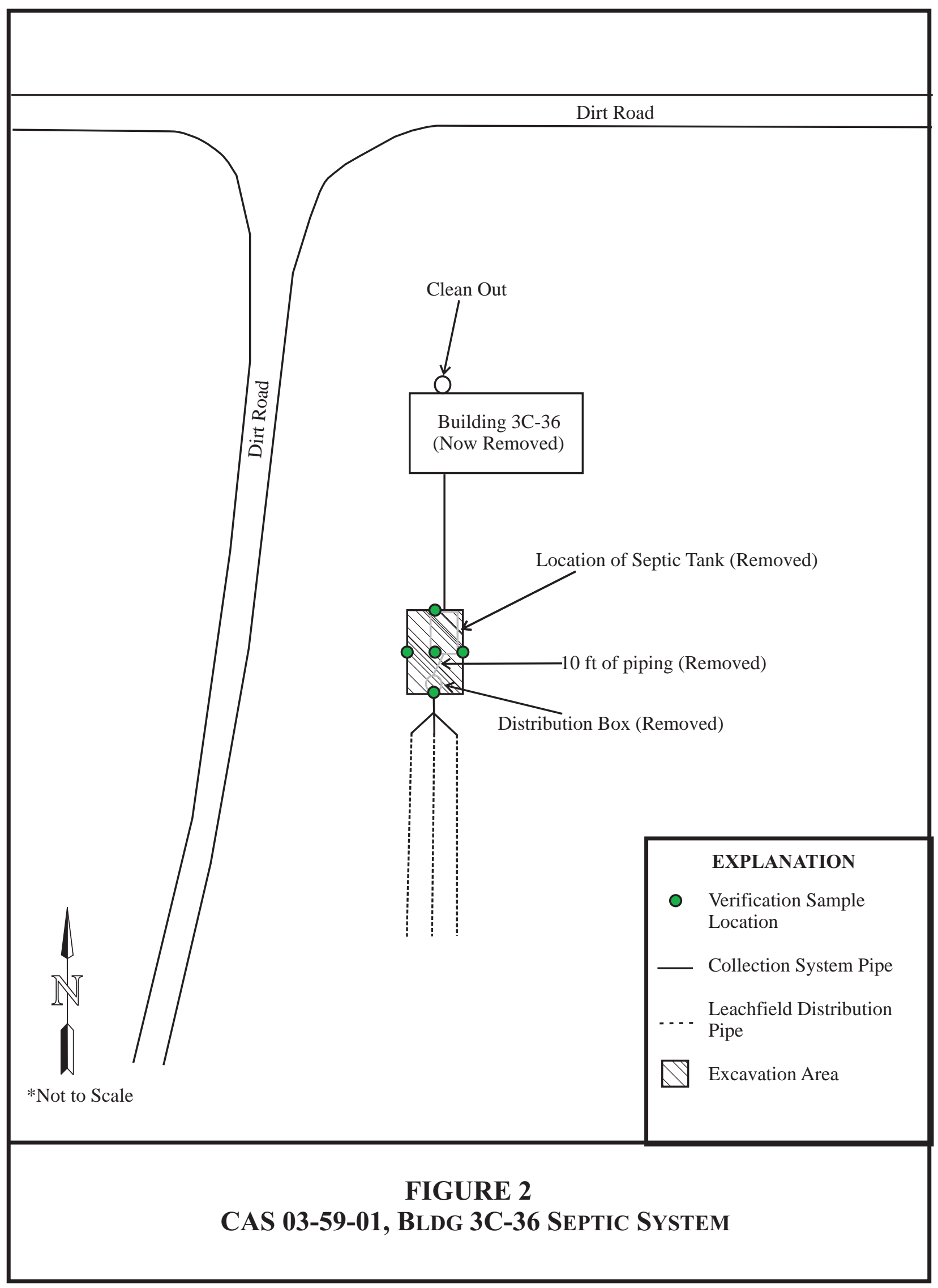




\subsubsection{CAS 03-59-02, Bldg 3C-45 Septic System}

Figure 3 shows the site plan for CAS 03-59-02, which is located in the former Area 3 Camp north of Road 3-01 and west of Angle Road. The site consisted of a septic tank, distribution box, leachfield, two dry wells, and associated piping that serviced the former Building 3C-45 and adjacent photo processing laboratory. The influent and effluent portions of the septic tank together contained approximately 700 gal of liquid and solid waste. Characterization results reported TPH-DRO contamination above the action level in the solid and liquid phases of the material contained within the septic tank, as well as gross alpha and beta radiation exceeding the recommended levels for sewage lagoon disposal within the liquid phase (NNSA/NSO, 2004). Additional characterization sampling performed prior to the onset of fieldwork confirmed that the solid and liquid material within the septic tank did not constitute a radiological or hazardous waste. Analytical results are available in Appendix B of this report.

This CAS was clean closed by solidifying and removing the septic tank contents, removing the concrete septic tank, and disposing of the tank and tank contents at the NTS Area 6 Hydrocarbon Landfill. As a BMP, the two dry wells were excavated and disposed of at the Area 9 U10c Sanitary Landfill. Prior to disposal, additional waste characterization sampling was performed to verify the absence of silver from the drywell associated with the photo processing plant. Field screening was performed on samples from the bottom and base of the sidewalls of the septic tank excavation, and additional material was excavated as necessary. Upon the return of verification sample analytical results below action levels (see Section 4.0), the excavated area was backfilled with native material from an approved borrow source and graded to the approximate surrounding topographic contours.

\subsubsection{CAS 06-51-01, Sump and Piping, and CAS 06-51-03, Clean Out Box and Piping}

Figure 4 shows the site plan for CASs 06-51-01 and 06-51-03. These sites, which were separate portions of the underground waste disposal infrastructure adjacent to and in support of Building 660 , included an 82-ft pipe segment running north of the former location of the Building 660 septic tank and a clean out box and associated piping adjacent to the Building 660 foundation. Both the pipe segment and the clean out box and associated piping were reportedly impacted with TPH-DRO. Prior to disposal, additional waste characterization sampling was performed on the CAS 06-51-01 pipe to verify the absence of mercury above action levels. Analytical results are available in Appendix B of this report.

These CASs were clean closed by exposing and removing the 82-ft pipe segment, the clean out box, 0.5 cubic yards $\left(\mathrm{yd}^{3}\right)$ of TPH-impacted soil from the clean out box, and associated piping and disposing of the material at the Area 6 Hydrocarbon Landfill. Additionally, a 55-gal sump

was encountered during the removal of the clean out box piping. As a BMP, the sump and $1 \mathrm{yd}^{3}$ of soil was characterized and disposed of as hydrocarbon waste at the Area 6 Hydrocarbon Landfill. Clean closure of the BMP sump excavation was verified by field screening. Field screening was performed on samples from the bottom and base of the sidewalls of the sump, pipe, and clean out box excavations, and additional material was excavated as necessary. Verification samples were taken from the pipe and clean out box excavations (see Section 4.0), and upon the receipt of analytical results below action levels, the areas were backfilled with clean soil from an approved borrow source and contoured to the surrounding topographic grade. 


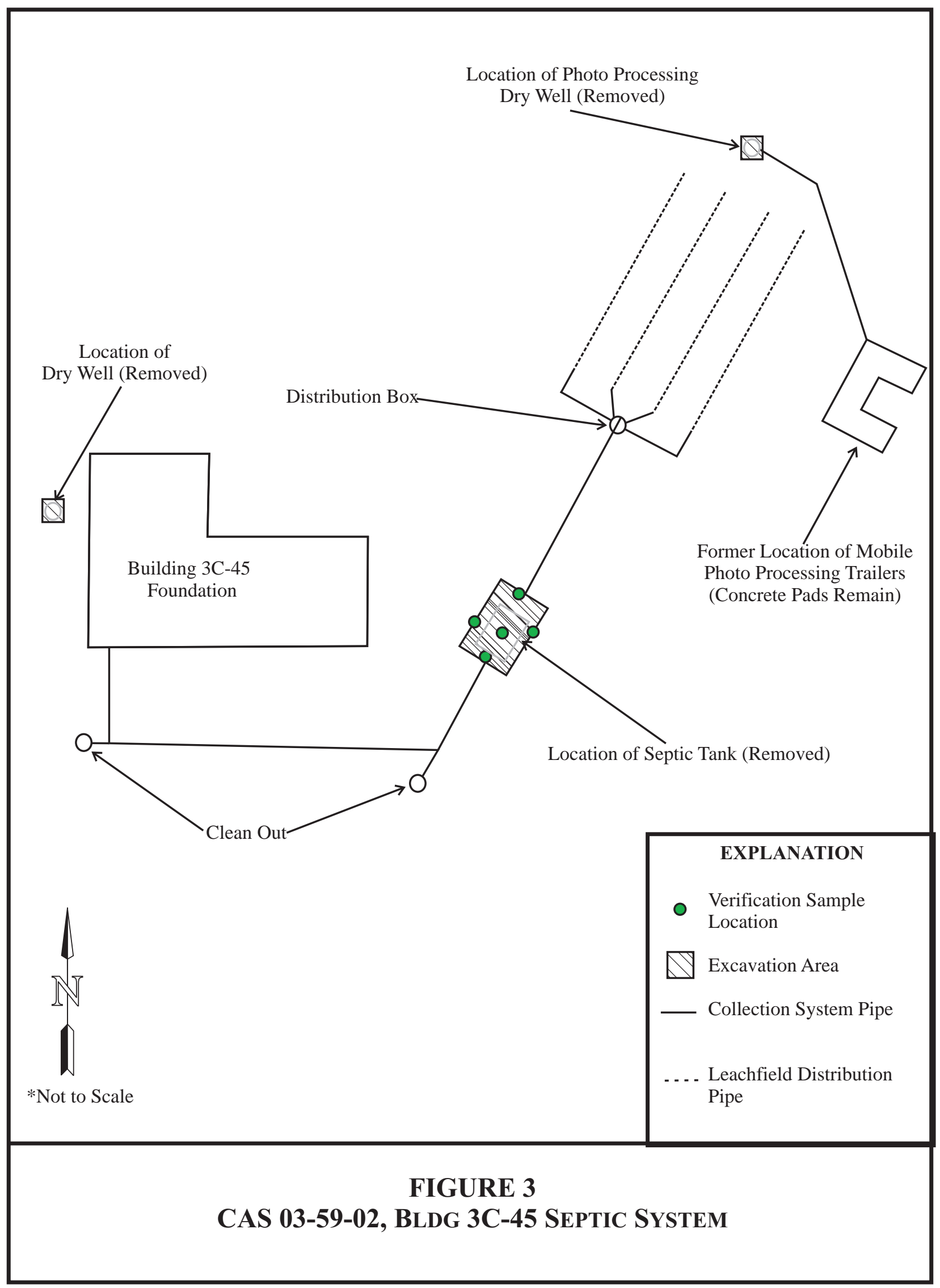




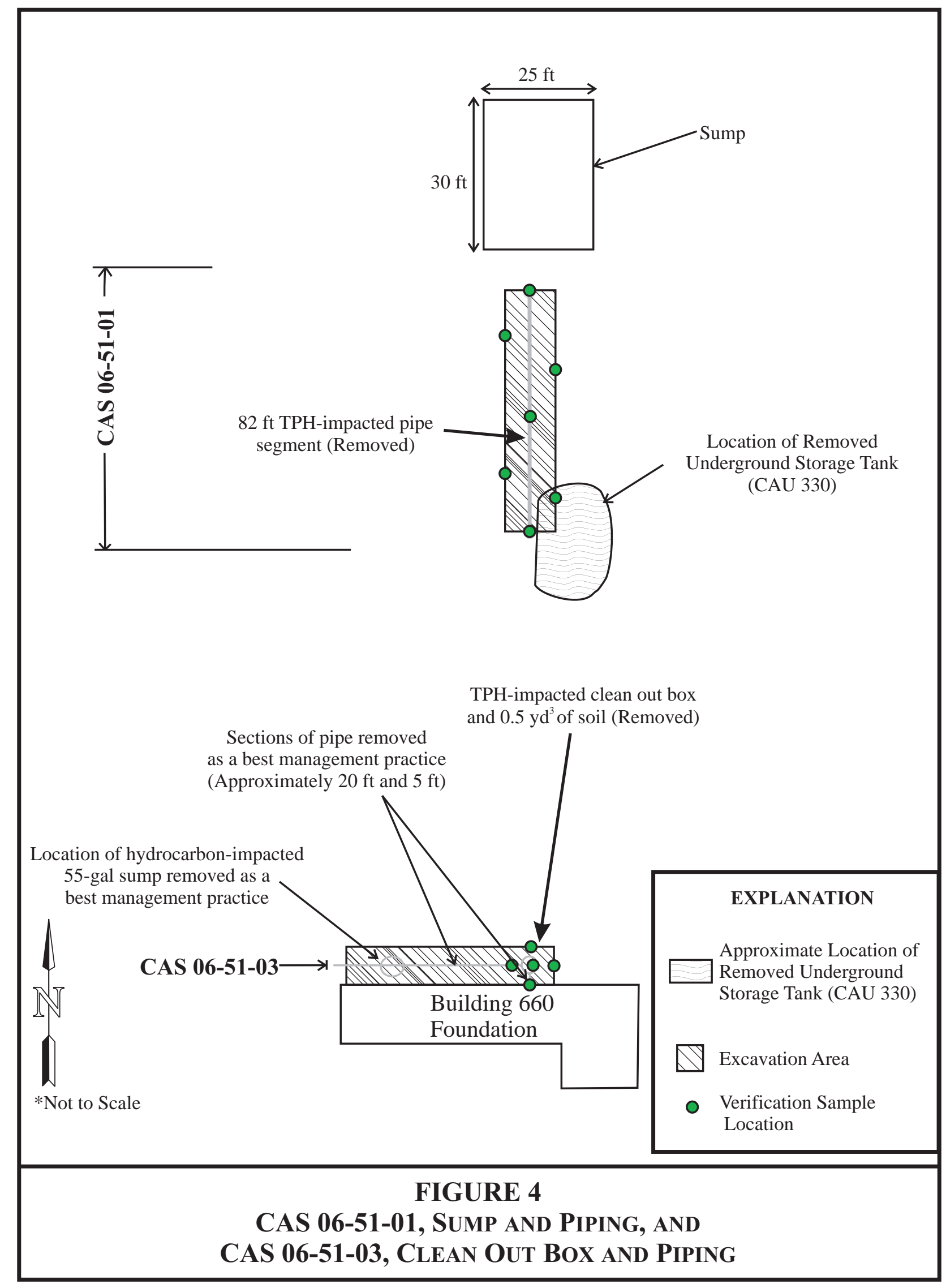




\subsection{Deviations From Corrective Action Plan as Approved}

A previously unidentified 55-gal sump was uncovered during excavation activities at CAS 06-51-03. Deviations from the approved CAP performed during the implementation of the CAU 516 CAP include the characterization, excavation, and disposal of approximately $1 \mathrm{yd}^{3}$ of soil around the sump and the 55-gal sump itself as a BMP. Sampling results confirmed that the sump was TPH-impacted, and field screening results obtained from the base and sidewalls of the excavation confirmed complete removal of TPH contamination and verified clean closure prior to backfilling.

No other deviations from the approved CAP were necessary during field activities.

\subsection{CoRrective Action ScHEdule As COMPLETED}

The completed closure field activities schedule is presented in Table 1.

Table 1. CAU 516 Closure Schedule

\begin{tabular}{|l|l|}
\hline \multicolumn{1}{|c|}{ SITE } & DATE CORRECTIVE ACTIONS COMPLETED* \\
\hline CAS 03-59-01 & December 10, 2006 \\
\hline CAS 03-59-02 & December 10, 2006 \\
\hline CAS 06-51-01 & December 13, 2006 \\
\hline CAS 06-51-03 & December 14, 2006 \\
\hline $\begin{array}{l}\text { Notes: * Corrective action activities do not include post-closure photo documentation } \\
\text { site visits. Post-closure site visits were completed December 14, 2006. }\end{array}$ \\
\hline
\end{tabular}

\subsection{Site Plan / Survey Plat}

No engineering “as-built” drawings were required for closure activities conducted at CAU 516. 


\subsection{WASTE DISPOSITION}

Waste generated during CAU 516 closure activities included hydrocarbon waste and sanitary waste/construction debris. All waste was managed according to federal and state regulations, DOE orders, and NSTec procedures. Some waste required sampling to verify the appropriate waste disposition. All waste was containerized, as needed, for proper disposal in an approved landfill. Table 2 summarizes disposition of each waste stream by CAS. Waste disposition documentation is included in Appendix $\mathrm{C}$ of this report.

TABLE 2. Disposition OF WASTE

\begin{tabular}{|c|l|c|l|}
\hline CAS & \multicolumn{1}{|c|}{ MATERIAL } & WEIGHT ESTIMATE & \multicolumn{1}{c|}{ DISPOSITION } \\
\hline \hline \multirow{2}{*}{ 03-59-01 } & TPH-impacted soil/debris & 84 tons & $\begin{array}{l}\text { NTS Area 6 } \\
\text { Hydrocarbon Landfill }\end{array}$ \\
\cline { 2 - 4 } & $\begin{array}{l}\text { Miscellaneous sanitary waste/ } \\
\text { construction debris }\end{array}$ & 10 tons & $\begin{array}{l}\text { NTS Area 9 U10c } \\
\text { Sanitary Landfill }\end{array}$ \\
\hline \multirow{2}{*}{ 03-59-02 } & TPH-impacted soil/debris & 101 tons & $\begin{array}{l}\text { NTS Area 6 } \\
\text { Hydrocarbon Landfill }\end{array}$ \\
\cline { 2 - 4 } & $\begin{array}{l}\text { Miscellaneous sanitary waste/ } \\
\text { construction debris }\end{array}$ & 79 tons & $\begin{array}{l}\text { NTS Area 9 U10c } \\
\text { Sanitary Landfill }\end{array}$ \\
\hline $\begin{array}{l}\text { 06-51-01/ } \\
06-51-03\end{array}$ & TPH-impacted soil/debris & 1 ton & $\begin{array}{l}\text { NTS Area 6 } \\
\text { Hydrocarbon Landfill }\end{array}$ \\
\hline
\end{tabular}

\subsection{WASTE Minimization}

Industry standard waste minimization practices were applied throughout the course of field activities. These practices included:

- Using TPH field test kits to field screen for TPH contamination and allow for a better delineation of the extent of TPH contamination

- Using laboratory analysis to characterize and classify waste streams

\subsection{HYDROCARBON WASTE}

Approximately 186 tons of TPH-DRO-impacted soil and solidified liquid were removed and/or excavated from CASs 03-59-01, 03-59-02, 06-51-01, and 06-51-03 and were disposed of at the Area 6 Hydrocarbon Landfill. Waste disposal documentation is included in Appendix C of this report.

\subsection{SANITARY WASTE}

Approximately 89 tons of sanitary waste, such as sanitary trash, personal protective equipment, and construction debris, was disposed of at the Area 9 U10c Sanitary Landfill. Waste disposal documentation is included in Appendix $\mathrm{C}$ of this report. 
CAU 516 Closure Report

Section: Waste Disposition

Revision: 0

Date: April 2007

\section{THIS PAGE INTENTIONALLY LEFT BLANK}




\subsection{CLOSURE VERIFICATION RESULTS}

Site closure was verified by the collection and analysis of verification samples, photographic documentation, and visual inspections.

At CAS 03-59-01, five verification samples and one blind duplicate sample were collected from the bottom and base of the sidewalls of the excavation (see Figure 2). Samples were collected on October 2, 2006, and were analyzed for TPH. Results were below action levels, verifying that the site was clean closed.

At CAS 03-59-02, five verification samples and one blind duplicate were collected from the bottom and base of the sidewalls of the excavation (see Figure 3). Samples were collected on September 27, 2006, and were analyzed for TPH. Results were below action levels, and the site was clean closed.

At CAS 06-51-01, seven verification samples were collected from the bottom and base of the sidewalls of the pipe excavation (see Figure 4). Samples were collected on November 28, 2006, and were analyzed for TPH. All results were below action levels, verifying that the excavated area is free of TPH contamination, and the site was clean closed.

At CAS 06-51-03, five verification samples were collected from the bottom and base of the sidewalls of the clean out box excavation on Novermber 28, 2006, and were analyzed for TPH to verify clean closure of the site. As a BMP, field screening was performed on soil taken from the sidewalls and base of the BMP 55-gal sump excavation (see Figure 4) to verify clean closure. All results were below action levels, verifying that the excavated area is free of TPH contamination, and the site was clean closed.

All samples were handled according to the Industrial Sites Quality Assurance Project Plan (QAPP) (U.S. Department of Energy, National Nuclear Security Administration Nevada Operations Office [NNSA/NV, 2002]). The samples were shipped under chain of custody to an approved offsite laboratory for analysis of TPH. Table 3 and Appendix B summarize the results. The analytical results for soil verification samples collected from the excavations at all CAU 516 CASs were below the action levels.

Critera for verification sampling and backfilling were provided in the approved CAU 516 CAP (NNSA/NSO, 2005). 


\section{Table 3. Verification Sample Analytical Results}

\begin{tabular}{|c|c|c|}
\hline \multirow{3}{*}{ SAMPLE ID } & \multirow{3}{*}{ DATE COLLECTED } & RESUlts \\
\hline & & $\begin{array}{c}\text { TPH-DRO } \\
\text { (mg/kg) }\end{array}$ \\
\hline & & Action Level $=\mathbf{1 0 0 . 0}$ \\
\hline 035901-V1 & $10 / 02 / 2006$ & 13.1 \\
\hline 035901-V2 & $10 / 02 / 2006$ & 7.3 \\
\hline 035901-V3 & $10 / 02 / 2006$ & 7.6 \\
\hline 035901-V4 & 10/02/2006 & 6.8 \\
\hline 035901-V5 & $10 / 02 / 2006$ & 7.5 \\
\hline $\begin{array}{c}\text { 035901-V6 } \\
\text { (Blind duplicate of } \\
\text { 035901-V1) }\end{array}$ & $10 / 02 / 2006$ & 12.2 \\
\hline 035902-V1 & 09/27/2006 & 12.9 \\
\hline 035902-V2 & 09/27/2006 & 12 \\
\hline 035902-V3 & 09/27/2006 & 7.1 \\
\hline 035902-V4 & 09/27/2006 & 11.8 \\
\hline 035902-V5 & $09 / 27 / 2006$ & 5.8 \\
\hline $\begin{array}{c}\text { 035902-V6 } \\
\text { (Blind duplicate of } \\
\text { 035902-V2) }\end{array}$ & 09/27/2006 & 12.6 \\
\hline 065101-V1 & $11 / 28 / 2006$ & 5.9 \\
\hline 065101-V2 & $11 / 28 / 2006$ & 5.1 \\
\hline 065101-V3 & 11/28/2006 & 6.0 \\
\hline 065101-V4 & $11 / 28 / 2006$ & 50 \\
\hline 065101-V5 & $11 / 28 / 2006$ & 5.9 \\
\hline 065101-V6 & $11 / 28 / 2006$ & 5.5 \\
\hline 065101-V7 & $11 / 28 / 2006$ & 5.4 \\
\hline 065103-V1 & $11 / 28 / 2006$ & 12.8 \\
\hline 065103-V2 & $11 / 28 / 2006$ & 5.4 \\
\hline 065103-V3 & $11 / 28 / 2006$ & 9.4 \\
\hline 065103-V4 & $11 / 28 / 2006$ & 12 \\
\hline 065103-V5 & $11 / 28 / 2006$ & 18.5 \\
\hline $\begin{array}{l}\text { Notes: } \\
\mathrm{mg} / \mathrm{kg}=\end{array}$ & & \\
\hline
\end{tabular}




\subsection{Data Quality Assessment}

Accurate and defensible analytical data were collected to verify that wastes were properly characterized, managed, and disposed, and to verify that clean-up criteria were met. The following sections describe the quality assurance/quality control (QA/QC) procedures, data validation process, and reconciliation of the conceptual site model with the observations and findings during the closure activities.

\subsubsection{Quality Assurance/Quality Control Procedures}

Detailed information about the QA/QC program can be found in the Industrial Sites QAPP (NNSA/NV, 2002). One blind duplicate verification sample per twenty samples or one blind duplicate sample per sampling event was collected and submitted blind to the laboratory for analysis. In addition, one equipment rinsate sample was collected per sampling event and submitted for analysis. Results showed no contamination resulted from the decontaminated sampling equipment. Analytical results for waste characterization samples were validated by the laboratory with respect to the data quality indicators. Matrix spikes, matrix spike duplicates, recoveries, and other standard QA/QC procedures were followed. The laboratory reports and validation reports indicate no problems with the usability of the data.

\subsubsection{Data Validation}

Data validation was performed according to the Industrial Sites QAPP (NNSA/NV, 2002). All sample data were internally validated using Tier I criteria. No anomalies were discovered in the data that would discredit any of the waste classification or verification samples collected and analyzed for CAU 516. Summary laboratory QA/QC data for verification samples are presented in Appendix B of this report. The complete data set and verification reports are available on request. These data are maintained in NSTec project files located in the Environmental Restoration project offices at the NTS.

\subsubsection{Conceptual Site Model}

There were no discrepancies between the conceptual site model presented in the DQOs (Appendix A of this report) and that observed in the field.

\subsection{USE RESTRICTIONS}

The preferred closure alternatives for all CASs requiring remediation activities were no further action or clean closure, and as a result, no Use Restrictions were required or implemented during the closure of CAU 516. 
CAU 516 Closure Report

Section: Closure Verification Results

Revision: 0

Date: April 2007

\section{THIS PAGE INTENTIONALLY LEFT BLANK}




\subsection{CONCLUSIONS AND RECOMMENDATIONS}

CAU 516 was closed according to the FFACO and the NDEP-approved CAP for CAU 516 (NNSA/NSO, 2005). Closure of CAU 516 was accomplished by completing the following tasks:

- $\quad$ Removing, solidifying, and disposing of TPH-impacted septic tank contents, and removing and disposing of the septic tank, at CAS 03-59-01

- $\quad$ Removing and disposing of a distribution box and $10 \mathrm{ft}$ of piping at CAS 03-59-01 as a BMP

- $\quad$ Removing, solidifying, and disposing of TPH-impacted septic tank contents, and removing and disposing of the septic tank, at CAS 03-59-02

- $\quad$ Excavating and removing two dry wells at CAS 03-59-02 as a BMP

- $\quad$ Removing and disposing of TPH-impacted piping at CAS 06-51-01

- Removing and disposing of a clean out box, TPH-impacted clean out box contents, and associated piping at CAS 06-51-03

- Characterizing, excavating, and removing a TPH-impacted 55-gal sump and surrounding soil discovered during fieldwork at CAS 06-51-03, which was clean closed as a BMP

- Collecting verification samples to verify clean-up criteria

- $\quad$ Backfilling and grading excavations to surrounding topographic contours

According to the CAU 516 CADD, no COCs were reported and no further action was taken at the following CASs (NNSA/NSO, 2004):

- CAS 06-51-02, Clay Pipe and Debris

- CAS 22-19-04, Vehicle Decontamination Area

\subsection{Post-Closure Monitoring Requirements}

\subsubsection{Inspections}

Since no Use Restrictions were implemented, no post-closure inspections are required for any CAU 516 CASs.

\subsection{NOTICE OF COMPLETION}

Based upon the completion of site activities, it is requested that a "Notice of Completion" be provided by NDEP for CAU 516. Upon closure approval, CAU 516 will be moved from Appendix III to Appendix IV, "Closed Corrective Action Units,” of the FFACO. 
CAU 516 Closure Report

Section: Conclusions/Recommendations

Revision: 0

Date: April 2007

THIS PAGE INTENTIONALLY LEFT BLANK 


\subsection{REFERENCES}

FFACO, see Federal Facility Agreement and Consent Order.

Federal Facility Agreement and Consent Order, 1996 (as amended). Agreed to by the State of Nevada, the U.S. Department of Energy, and the U.S. Department of Defense.

National Security Technologies. LLC, 2006a. Field Management Plan for Corrective Action Unit 516: Septic Systems and Discharge Points, Nevada Test Site, Nevada. Las Vegas, NV.

National Security Technologies. LLC, 2006b. Site-Specific Site Health and Safety Plan for Corrective Action Unit 516: Septic Systems and Discharge Points, Nevada Test Site, Nevada. Las Vegas, NV.

NNSA/NSO, see U.S. Department of Energy, National Nuclear Security Administration Nevada Site Office.

NNSA/NV, see U.S. Department of Energy, National Nuclear Security Administration Nevada Operations Office.

NSTec, see National Security Technologies, LLC.

U.S. Department of Energy, National Nuclear Security Administration Nevada Operations Office, 2002. Industrial Sites Quality Assurance Project Plan, Nevada Test Site, Nevada, Rev. 3. DOE/NV--372. Las Vegas, NV.

U.S. Department of Energy, National Nuclear Security Administration Nevada Site Office, 2003. Corrective Action Investigation Plan for Corrective Action Unit 516: Septic Systems and Discharge Points, Nevada Test Site, Nevada, Rev. 0. DOE/NV--889. Las Vegas, NV.

U.S. Department of Energy, National Nuclear Security Administration Nevada Site Office, 2004. Corrective Action Decision Document for Corrective Action Unit 516: Septic Systems and Discharge Points, Nevada Test Site, Nevada, Rev. 1. DOE/NV--957. Las Vegas, NV.

U.S. Department of Energy, National Nuclear Security Administration Nevada Site Office, 2005. Corrective Action Plan for Corrective Action Unit 516: Septic Systems and Discharge Points, Nevada Test Site, Nevada, Rev. 0. DOE/NV--1071. Las Vegas, NV. 
CAU 516 Closure Report

Section: References

Revision: 0

Date: April 2007

THIS PAGE INTENTIONALLY LEFT BLANK 


\section{APPENDIX A}

\section{DATA QUALITY OBJECTIVES*}

* As previously published in the approved Corrective Action Investigation Plan for Corrective Action Unit 516: Septic Systems and Discharge Points, Nevada Test Site, Nevada, Rev. 0. DOE/NV--889. Las Vegas, NV. 
CAU 516 Closure Report Section: Appendix A

Revision: 0

Date: April 2007

THIS PAGE INTENTIONALLY LEFT BLANK 
Revision: 0

Date: 05/02/2003

Page A- 1 of A-55

\section{Appendix A.1}

\section{Data Quality Objectives}




\section{A.1 Data Quality Objectives Process}

The DQO process is a seven-step strategic planning approach based on the scientific method that is used to prepare for site characterization data collection. The DQOs are designed to ensure that the data collected will provide sufficient and reliable information to identify, evaluate, and technically defend potentially viable corrective actions (i.e., no further action, closure in place, or clean closure). With the exception of CAS 06-51-02, existing information about the nature and extent of contamination at the CASs in CAU 516 is insufficient to evaluate and select preferred corrective actions; therefore, a corrective action investigation will be conducted.

The CAU 516 investigation will be based on DQOs developed by representatives of the NNSA/NSO. Corrective Action Site 06-51-02, Clay Pipe and Debris, does not require characterization, so the debris will be removed from the site during the field investigation. Therefore, this DQO process will not apply to CAS 06-51-02. The seven steps of the DQO process developed for the remaining CASs in CAU 516 and presented in Sections A.1.2 through A.1.8 were developed based on the CAS-specific information presented in Section A.1.1.

\section{A.1.1 CAS-Specific Information}

The five CASs addressed herein are located in Areas 3, 6, and 22 of the NTS as shown in Figure A.1-1. Two CASs are in Area 3, two CASs are in Area 6, and one CAS is in Area 22. The five CASs are:

- 03-59-01, Building 3C-36 Septic System

- 03-59-02, Building 3C-45 Septic System

- 06-51-01, Sump and Piping

- 06-51-03, Clean Out Box and Piping

- 22-19-04, Vehicle Decontamination Area

The COPCs specific to each CAS are described in the following CAS descriptions and listed in Table A.1-1. Critical COPCs are defined as those contaminants that are known or expected to be present within a CAS. Noncritical COPCs are defined as classes of contaminants (e.g., VOCs) that include all the analytes reported from the respective analytical methods that have PALs listed in Section A.1.4.2. If a COPC is detected in any sample at a concentration above a PAL, the COPCs 


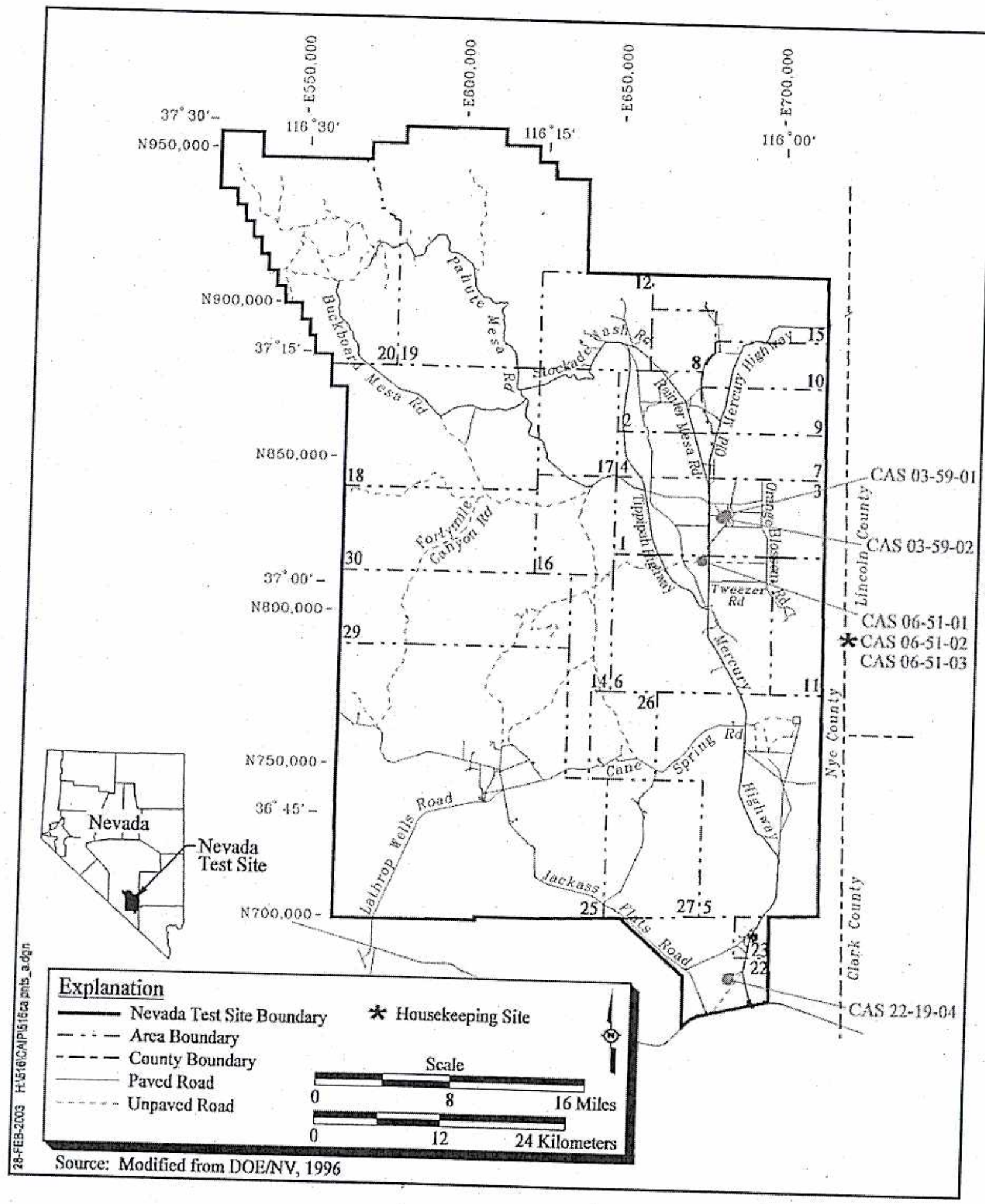

Figure A.1-1 
Table A.1-1

Phase I Contaminants of Potential Concern Per CAS

\begin{tabular}{|c|c|c|c|c|c|c|}
\hline \multirow[b]{2}{*}{ COPC } & \multirow[b]{2}{*}{ 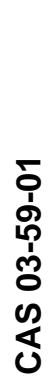 } & \multicolumn{2}{|c|}{ CAS 03-59-02 } & \multirow[b]{2}{*}{$\begin{array}{l}5 \\
1 \\
10 \\
0 \\
0 \\
0 \\
0\end{array}$} & \multirow[b]{2}{*}{$\begin{array}{l}n \\
\frac{1}{0} \\
0 \\
0 \\
0 \\
0\end{array}$} & \multirow[b]{2}{*}{ 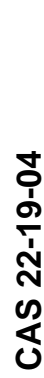 } \\
\hline & & 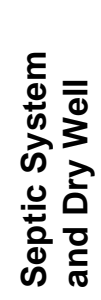 & 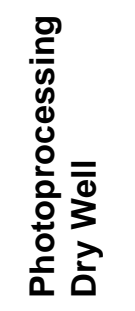 & & & \\
\hline \multicolumn{7}{|c|}{ Organics } \\
\hline VOCs & $\mathrm{X}$ & $X$ & $\mathrm{X}$ & $X$ & $\mathrm{X}$ & $\mathrm{X}$ \\
\hline SVOCs & $\mathrm{X}$ & $\mathrm{X}$ & $X$ & $X$ & $X$ & $\mathrm{X}$ \\
\hline Hydroquinone & -- & -- & $\mathrm{C}$ & -- & -- & -- \\
\hline PCBs & $\mathrm{X}$ & $x$ & $X$ & $\mathrm{X}$ & $\mathrm{X}$ & $\mathrm{X}$ \\
\hline \multirow{2}{*}{ 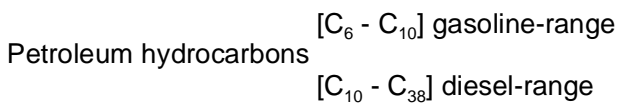 } & $x$ & $x$ & $x$ & $X$ & $x$ & $X$ \\
\hline & $X$ & $x$ & $x$ & $X$ & $x$ & $X$ \\
\hline \multicolumn{7}{|c|}{ Metals } \\
\hline RCRA metals & $\mathrm{X}$ & $\mathrm{X}$ & $\begin{array}{l}\mathrm{C} \text { - silver } \\
\mathrm{X} \text { - others }\end{array}$ & $\mathrm{X}$ & $\mathrm{X}$ & $\mathrm{X}$ \\
\hline Beryllium & $X$ & $x$ & $x$ & $X$ & $X$ & X \\
\hline Aluminum & -- & -- & C & -- & -- & -- \\
\hline \multicolumn{7}{|c|}{ Radionuclides } \\
\hline Americium-241 & -- & -- & -- & $\mathrm{C}$ & C & -- \\
\hline Cesium-137 & -- & $x$ & -- & C & $\mathrm{C}$ & X \\
\hline Strontium-90 & -- & $\mathrm{X}$ & -- & C & C & $\mathrm{X}$ \\
\hline Plutonium-238 and $-239 / 240$ & -- & $\mathrm{X}$ & -- & C & C & $\mathrm{X}$ \\
\hline Uranium-234, -235, -238 & -- & -- & -- & -- & -- & $X$ \\
\hline
\end{tabular}

*Footnote:

-For those COPCs identified that include multiple parameters, the parameters with PALs will be evaluated.

$\mathrm{C}=$ Critical COPCs $\mathrm{X}=$ Noncritical COPCs $\quad--=$ Not Applicable 
will be identified as a COC. If a COC is identified, the CAS containing that $\mathrm{COC}$ will be further investigated to determine the extent of the contamination.

As discussed above, CAU 516 also includes CAS 06-51-02 located in Area 6. However, this site is not included in the DQO process because characterization data are not required to support the housekeeping action.

\section{A.1.1.1 CAS 03-59-01, Building 3C-36 Septic System}

Physical Setting and Operational History - This CAS is located in the former Area 3 Camp south of Road 3-01 and consists of a septic tank, leachfield, distribution box, and septic system piping (see Figure A.1-2). The septic tank has a volume of 1,200 gal and is believed to have been pumped and filled with concrete. The leachfield is located approximately $76 \mathrm{ft}$ south of Building $3 \mathrm{C}-36$ leachfield. The leachfield is approximately 60 by $30 \mathrm{ft}$ and consists of three perforated 4-in. pipes. This septic system was connected to Building 3C-36, which contained seven offices, one blueprint room, one secretarial area, and one rest room that included one shower stall, one toilet, one sink, and one floor drain. The septic system was constructed in 1985 and most likely used until Building 3C-36 was abandoned in 1992.

Sources of Potential Contamination - According to three interviewees, the septic system for Building 3C-36 received only sewage from one rest room within the building (Marshall, 2002; Boyd, 2002; and Dalson, 2002a).

Previous Investigation Results - A radiological survey was conducted at various exterior points within the leachfield. Based on this survey and historical documentation, there is little likelihood of any radiological concerns at this site. (Adams, 2001)

Contaminants of Potential Concern - No critical COPCs were identified for this CAS. The following noncritical COPCs identified for this CAS are based on interviews, common NTS concerns, and process knowledge:

- VOCs, SVOCs, petroleum hydrocarbons, and RCRA metals are representative of general characteristics of sewage (Boyd, 2002; Dalson, 2002a; Marshall, 2002; and People for Puget Sound, 2001). 


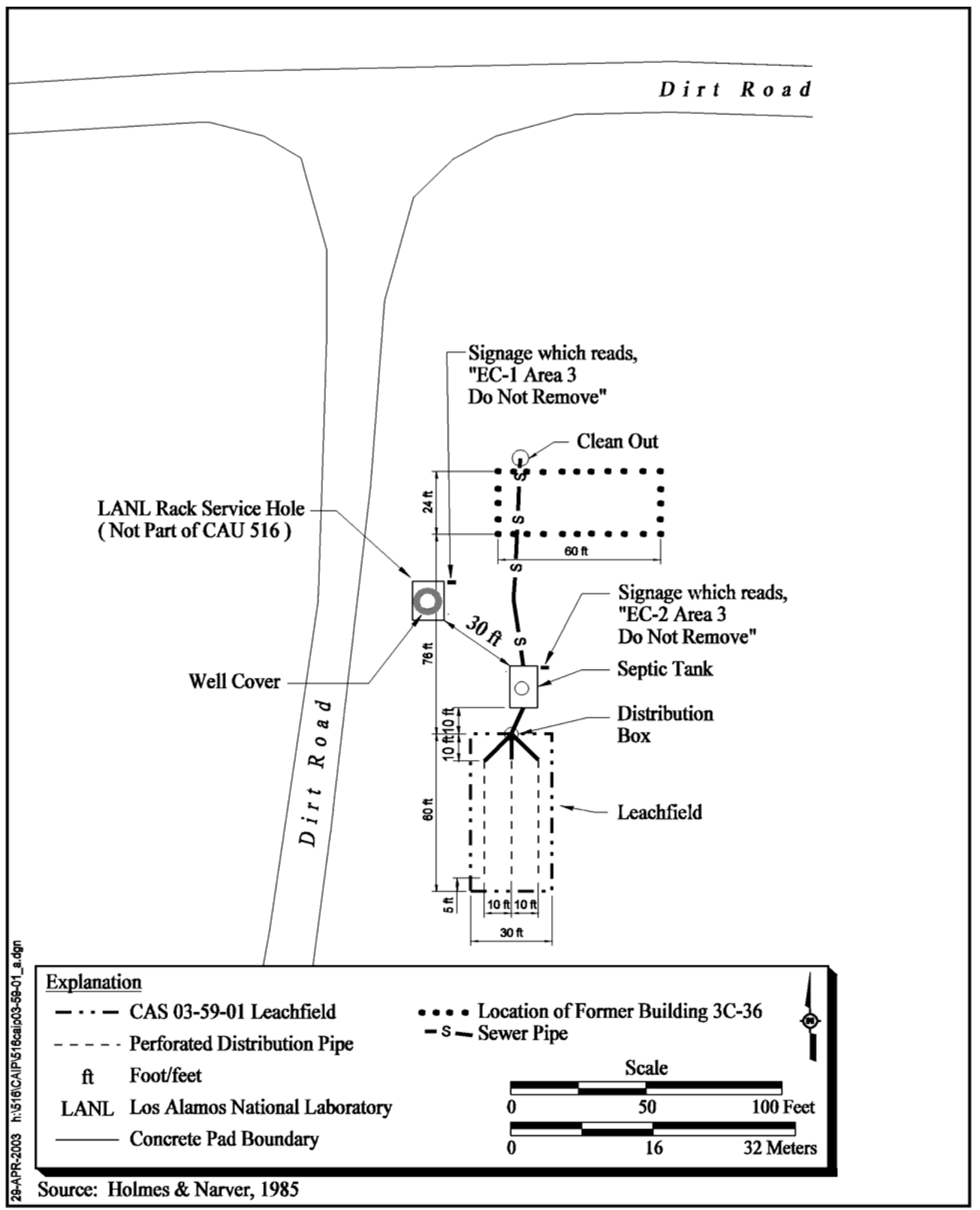

Figure A.1-2

CAS 03-59-01, Building 3C-36 Septic System 
- Beryllium and PCBs are common concerns at the NTS and have not been ruled out at this CAS based upon process knowledge.

\section{A.1.1.2 CAS 03-59-02, Building 3C-45 Septic System}

Physical Setting and Operational History - This CAS is located north of Road 3-01 and west of Angle Road in Area 3 and consists of a septic tank, leachfield, distribution box, and associated piping that serviced Building 3C-45 (see Figure A.1-3). Also included in the CAS is a dry well used for the disposal of photoprocessing chemicals. Engineering drawings indicate that the 1,200-gal septic tank is constructed of precast concrete and located northeast of Building 3C-45 at a depth of approximately $2 \mathrm{ft}$ bgs. The leachfield is approximately $77 \mathrm{ft}$ northeast of the Building $3 \mathrm{C}-45$ and has dimensions of about 98 by $59 \mathrm{ft}$ (IT, 2001). The dry well is located about $8 \mathrm{ft}$ northeast of the leachfield, is $4 \mathrm{ft}$ in diameter, has a total depth of approximately $12 \mathrm{ft}$ bgs (Holmes \& Narver, 1978), and a volume estimated at $151 \mathrm{ft}^{3}$ (IT, 2001). Building 3C-45 was in operation from 1974 until 1990 or 1991, had one rest room, and was used for electrical component fabrication, storage, and as a support facility for the neighboring Diode Facility. One interviewee reported the storage of nuclear racks within Building 3C-45 (Dalson, 2002b). Another interviewee commented on the fabrication, use, and storage of electrical components within Building 3C-45 (Marshall, 2002).

In addition to the aforementioned CAS components, a borehole located approximately $10 \mathrm{ft}$ west of Building 3C-45 will also be investigated. Historical documentation refers to this borehole as a dry well belonging to LANL. The borehole was drilled on August 24, 1976, to a total depth of $44 \mathrm{ft}$ bgs. The borehole has no casing and has a 72 -in. diameter to $15.5 \mathrm{ft}$ bgs and a 48 -in. diameter to $44 \mathrm{ft}$ bgs (DOE/NV, 1990). An engineering drawing shows a 2-in. acid-resistant polypropylene sewer pipe near the base of the borehole and the borehole backfilled to grade (Holmes \& Narver, 1985). The purpose of the borehole is unknown.

Sources of Potential Contamination - The septic system was designed to receive domestic sewage from Building 3C-45. One interviewee stated that nuclear racks associated with electronic diagnostic activities were stored in Building 3C-45 (Dalson, 2000b). Photoprocessing took place in the mobile photoprocessing trailers and the waste chemicals from this process were reportedly disposed of in the dry well. 


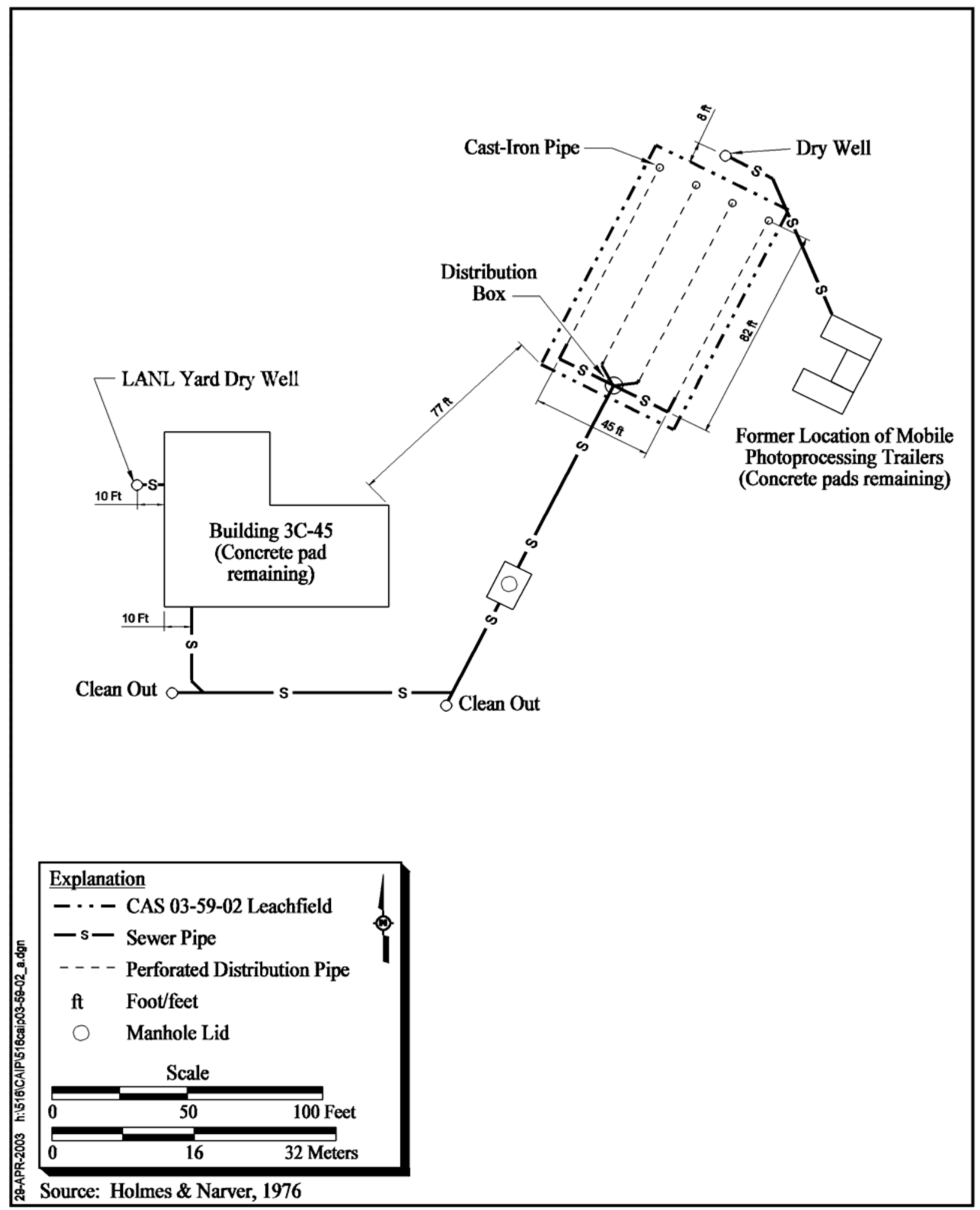

Figure A.1-3

CAS 03-59-02, Building 3C-45 Septic System 
Previous Investigation Results - Although documentation was found with a characterization plan for the Building 3C-45 septic tank (REECo, 1995), it is unknown as to whether or not this was done. A radiological survey (IT, 2002) conducted at various points of the leachfield showed radiological readings did not exceed the background readings of the general area (Adams, 2001).

Contaminants of Potential Concern - The following critical COPCs identified for this CAS are based on an interview, product documentation, and process knowledge:

- Silver is released from the film during photograph developing (Phellan, 2002; and Sunspot Productions, 2002).

- Hydroquinone is in the developing agent used in photoprocessing (Kodak, 1998a; and Sunspot Productions, 2002).

- Aluminum is a component of a rapid fixer used in photoprocessing (Kodak, 1998b).

The noncritical COPCs identified below are based on interviews, common NTS concerns, and process knowledge:

- VOCs, SVOCs, petroleum hydrocarbons, and RCRA metals are representative of general characteristics of sewage (People for Puget Sound, 2001).

- Beryllium and PCBs are common concerns at the NTS and have not been ruled out based upon process knowledge.

- Cs-137, Sr-90, and Pu-238, -239/240 based on nuclear racks used for nuclear tests diagnostics stored in Building 3C-45 (Dalson, 2002b). There is insufficient information as to what capacity the nuclear racks were used; therefore, these radioisotopes will be analyzed to verify their absence.

\section{A.1.1.3 CAS 06-51-01, Sump and Piping; and CAS 06-51-03, Clean Out Box and Piping}

Physical Setting and Operational History - The CAS 06-51-01 is located in the Well 3 Yard in Area 6 and consists of a 4-in. vitreous clay pipe which trends north from Building 660 approximately $300 \mathrm{ft}$ into a sump (see Figure A.1-4). Four floor drains and two sink drains within Building 660 connect into this pipe. The sump is approximately 25 by $30 \mathrm{ft}$ and is located north of Building 660 . An UST and associated piping located north of Building 660 is assigned to CAS 06-02-04 in 


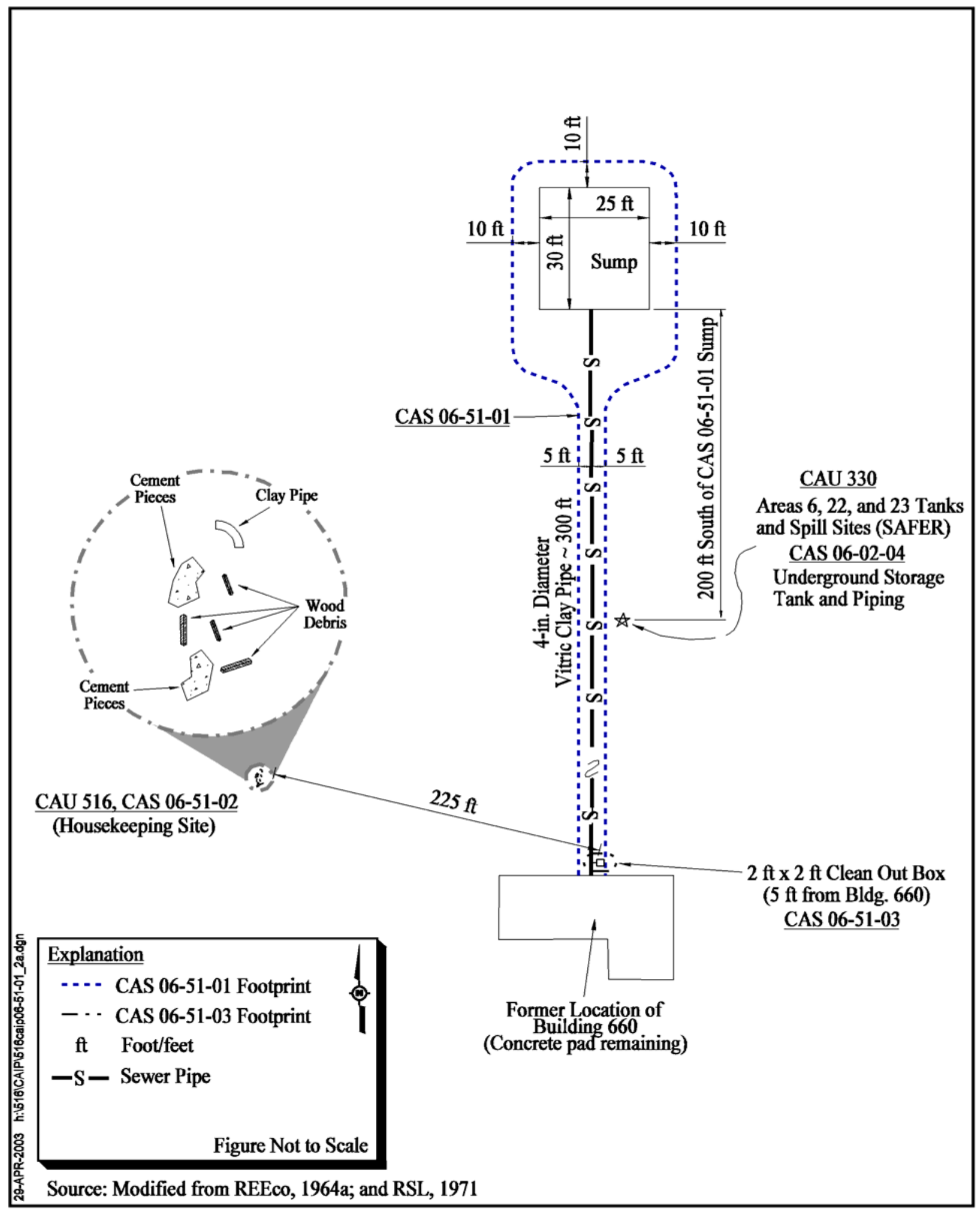

Figure A.1-4

CAS 06-51-01, Sump and Piping; CAS 06-51-02, Clay Pipe and Debris; and CAS 06-51-03, Clean Out Box and Piping 
CAU 330 and is not associated with CAU 516. One interviewee recalled the UST resembling a settling tank rather than a septic tank constructed out of concrete and clay piping (Laub, 2001).

The associated clean out box and piping resides within CAS 06-51-03 (see Figure A.1-4). This CAS consists of a clean out box made of wood and concrete that measures $2 \times 2 \times 3 \mathrm{ft}$ with a 6-in. cast-iron pipe with an end cap projecting into it from the west. The cast-iron pipe is believed to serve as an access pipe to the main 4-in. vitric clay pipe that extends north from Building 660 into the CAS 06-51-01 sump.

Building 660 was constructed in 1964 and was used until 1972 as a feed barn, dairy barn, slaughterhouse, and for the preparation of animal tissues for radiological monitoring and animal studies. After that the building was used to store tools, parts, and special pipe fittings until 1989. The building was reported to have also been used as a calibration laboratory (Madsen, 2001). In 1993, the sinks inside Building 660 were designated for hand washing only (Azhikakath, 1994).

Sources of Potential Contamination - According to historical documentation, Building 660 was discharging wastewater directly into the sump (REECo, 1994). An interviewee reported being told that radioactive animal feed was buried north of Building 660 and that all waste was discharged to the sump (Madsen, 2001). No evidence of buried material has been found. A document requesting closure of the CAU 330 UST stated that the use of Building WY-42 (also known as Building 660) was a cow barn, where cows were fed plutonium and americium contaminated hay and then slaughtered for study (Madsen, 2001; Sygitowicz, 1995). Drain lines connecting to the UST could not be verified. The document also indicates that wastewater generated within this building was directed through one sink and drain; however, the types of solvents or cleaners that might have been introduced into the sink and drain was undetermined (Sygitowicz, 1995). The engineering drawing RE-788 (REECo, 1964b) shows four floor drains and two sink drains in Building 660. The UST is not shown on any engineering drawings identified during this investigation. An engineering drawing shows transformers in the vicinity of Building 660 (REECo,1964a); although no report of PCB contamination or leaks were found during the preliminary assessment. During a 1994 investigation of Building 660, a Stop Work Order was issued for an unpermitted wastewater discharge as a result of wastewater discharging into a sump/leach pit rather than the UST for which it was intended. Water 
service was terminated and the sinks and drains were sealed inside and outside the building (REECo,1994).

Previous Investigation Results - No previous investigation results are identified for these CASs, but analytical results exist for a liquid sample collected in 1994 from the nearby UST in CAU 330 and submitted for analysis. The CAU 330 UST is located within $10 \mathrm{ft}$ of CASs 05-51-01 and 05-51-02 and is designated 06-02-04. The sample collected in 1994 was analyzed for the following analytical parameters: VOCs, SVOCs, TCLP metals, TPH (gasoline/diesel/oil-ranges), pH, Clor-d-tect 4000, gamma spectrometry, isotopic $\mathrm{Pu}$, and tritium. The analytical results reported the detection of chlorine, barium, caustics, corrosives, acids (Cowley, 1994); Pu-238, Pu-239, and tritium at concentrations below PALs (Latham, 1995). The pH of the sample was 7.94 (Cowley, 1994). Further investigation of the CAU 330 UST conducted in December 2002 verified that the drain lines connected to the UST are not connected to either CAS 06-51-01 or CAS 06-51-03 (Urbon, 2003). Additional liquid and sludge samples were collected from the UST in March 2003 and analyzed for TCLP VOCs, TCLP SVOCs, TCLP RCRA metals, TPH, PCBs, tritium, and alpha, beta and gamma-emitting radionuclides. Total petroleum hydrocarbons were detected at $191 \mathrm{mg} / \mathrm{kg}$ (Urbon, 2003).

Contaminants of Potential Concern - The following critical COPCs identified for this CAS are based on process knowledge and previous analytical results:

- $\mathrm{Pu}-238$ and -239/240 (Latham, 1995) were detected below the MDLs in the UST liquid sample collected from CAU 330, CAS 06-04-02, and were used in the animal feed used in animal investigation studies (Madsen, 2001; Sygitowiciz, 1995)

- Am-241, and Pu-238 and -239/240 from animal feed used in animal investigation studies (Madsen, 2001; Sygitowicz, 1995)

- Cs-137 and Sr-90 based on historical documentation regarding the Animal Investigation Program (EPA, 1984). Analyses will be performed to verify their absence. 
The noncritical COPCs identified below are based on process knowledge, common NTS concerns, and historical documentation:

- VOCs, SVOCs, petroleum hydrocarbons, and RCRA metals are representative of general characteristics of sewage (People for Puget Sound, 2001).

- Beryllium and PCBs are common concerns at the NTS and have not been ruled out based upon process knowledge.

\section{A.1.1.4 CAS 22-19-04, Vehicle Decontamination Area}

Physical Setting and Operational History - This CAS, 06-51-03, is a former vehicle decontamination area located approximately $800 \mathrm{ft}$ southwest of the Weather Station in Area 22 (see Figure A.1-5). The vehicle decontamination site consists of a decontamination pad, a drainage trench, and a sump. The decontamination pad is rectangular, measures 32-ft long and 15-ft wide, and is topped with gravel ranging from approximately 5 to $10 \mathrm{in}$. in diameter. The drainage trench measures 30-ft long, 3-ft wide, and 2-ft deep and runs between the decontamination pad and sump. The sump consists of a depression in the soil measuring 11-ft long, 9-ft wide, and 4-ft deep.

Review of Defense Nuclear Agency historical documents report that a series of atmospheric tests named Buster-Jangle were conducted in the 1950s. Camp Desert Rock was activated in 1951 for the Buster-Jangle tests. Operations at Camp Desert Rock took place from 1951 until 1964. Military personnel at Camp Desert Rock were trained in personnel and equipment monitoring, in decontamination procedures, and established and operated a decontamination station near the exercise location. Immediately after the test was conducted, the decontamination personnel monitored all participants who had exceeded the prescribed distance from ground zero. If gamma intensities exceeded 0.02 Roentgen per hour $(\mathrm{R} / \mathrm{h})$, the personnel and vehicles were directed to a nearby decontamination facility. Vehicles were decontaminated with detergent and water. Vehicles or equipment requiring further decontamination were often decontaminated at the Area 22 vehicle decontamination pad. (DNA, 1982)

Sources of Potential Contamination - Radioactive fallout from atmospheric detonations contaminated personnel and vehicles with alpha-, beta-, and gamma-emitting radionuclides. Long-lived radionuclides possibly remaining at this CAS are Cs-137, Sr-90, Pu-238, Pu-239/240, 


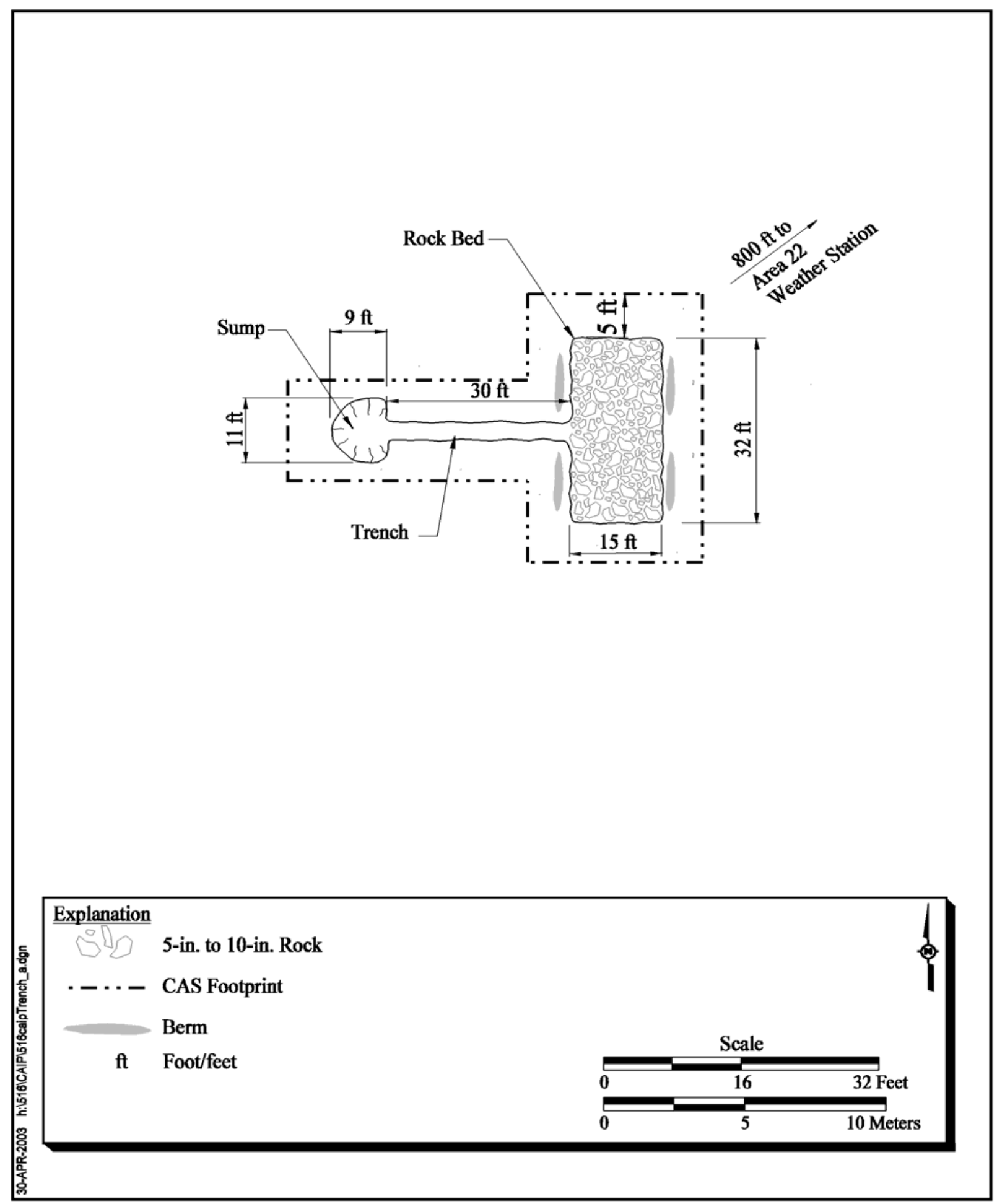

Figure A.1-5

CAS 22-19-04, Vehicle Decontamination Area 
U-234, U-235, and U-238. Vehicles were subsequently decontaminated using high-pressure water and detergents, releasing rinsate potentially contaminated with VOCs, SVOCs, RCRA metals, and petroleum hydrocarbons, along with radionuclides, into the washdown pad, trench, and sump, which may have resulted in the transport of the contaminants below surface.

Previous Investigation Results - An EM-31-DL terrain conductivity survey was completed in 2001 over a 60 - by 100 -ft rectangular area. The survey confirmed that no metallic debris was buried within the surveyed area (SAIC, 2001).

Radiological surveys were conducted in 1998 (IT, 1998) and 2002 (IT, 2002). All radiological survey readings were below or within background levels.

Gamma spectroscopy was conducted on a soil sample taken underneath the vehicle washdown pad in 2001. Cesium-137 was noted at $0.5 \mathrm{pCi} / \mathrm{g}$ and is within the environmental fallout range for atmospheric tests. It is unknown if Cs-137 was introduced into the soil from runoff during decontamination activities or from nuclear fallout activity. All other radionuclides detected are naturally occurring potassium-40, as well as U and thorium decay chains. (Emer, 2001)

Contaminants of Potential Concern - No critical COPCs were identified for this CAS. The following noncritical COPCs identified for this CAS are based on process knowledge and historical documentation:

- VOCs and SVOCs used for the decontamination process

- RCRA metals and TPH from the decontamination of equipment and vehicles fueled by and maintained with petroleum hydrocarbon products

- Cs-137, Sr-90, Pu-238, -239/240; and U-234, -235, -238 from atmospheric testing fallout or from the decontamination of vehicles and equipment

- Because beryllium and PCBs are common concerns at the NTS, they have not been ruled out based upon process knowledge 


\section{A.1.2 Seven-Step DQO Process}

This following section presents the seven-step DQO process for an investigation as applied to CAU 516.

\section{A.1.2.1 Step 1 - State the Problem}

This step identifies the DQO planning team members, describes the problem that has initiated the CAU 516 investigation, and develops CSMs.

\section{A.1.2.2 Planning Team Members}

The DQO planning team consists of representatives from NDEP, NNSA/NSO, Shaw Environmental, Inc. (Shaw), and Bechtel Nevada (BN). The primary decision makers include NDEP and NNSA/NSO representatives. Table A.1-2 lists representatives from each organization in attendance for the January 9, 2003, DQO meeting.

\section{A.1.2.3 Describe the Problem}

Corrective Action Unit 516 is being investigated because effluent contaminated with hazardous and/or radioactive constituents may have been discharged into the septic systems and/or discharge points at CASs 03-59-01, 03-59-02, 06-51-01, and 06-51-03, potentially contaminating the native soil underlying the leachfields. In addition, contaminated effluent may have escaped into the surrounding soil as a result of failures in the septic system design (e.g., uncapped terminating pipes) and/or in the structural integrity (e.g., breaches) in one or more components of the septic system (e.g., septic tank, distribution box, piping).

Wastewater contaminated with hazardous and/or radioactive constituents produced from decontamination activities at CAS 22-19-04 was released to the underlying and surrounding native soil as it washed onto an unlined gravel pad constructed to direct the wastewater to a sump via a gravel-lined trench.

As a result of the above activities, hazardous and/or radioactive constituents may be present at these CASs at concentrations that could potentially pose a threat to human health and/or the environment. 
Table A.1-2

DQO Meeting Participants

\begin{tabular}{|c|c|c|}
\hline Participant & Affiliation & Function \\
\hline Stacey Alderson & Shaw & Radiation Physics Lead \\
\hline Kevin Cabble & NNSA/NSO & $\begin{array}{l}\text { Environmental Restoration Division } \\
\text { Task Manager }\end{array}$ \\
\hline Jack Ellis & Shaw & Health and Safety Manager \\
\hline Grant Evenson & SAIC & Industrial Sites Field Coordinator \\
\hline Joe Hutchinson & SAIC & Radiological Data Validator \\
\hline Syl Hersh & Shaw & Quality Processes Technical Staff \\
\hline Robert Irwin & GRAM & Industrial Sites Technical Staff \\
\hline Bridget Iverson & GeoTrans & Preliminary Assessments Liaison \\
\hline Brad Jackson & $\mathrm{BN}$ & BN Task Manager \\
\hline Linda Linden & SAIC & Industrial Sites CAU Lead \\
\hline Joe Peters & SAIC & Chemical Data Validator \\
\hline George Petersen & SAIC & Industrial Sites Technical Staff \\
\hline Bill Nicosia & Shaw & Radiation Physics Technical Staff \\
\hline Barbara Quinn & SAIC & $\begin{array}{l}\text { Environmental Compliance and Waste } \\
\text { Management Lead }\end{array}$ \\
\hline James Traynor & $\mathrm{BN}$ & BN Task Manager \\
\hline Al Wickline & SAIC & Industrial Sites Technical Staff \\
\hline Jeanne Wightman & Shaw & Quality Processes Representative \\
\hline Dustin Wilson & SAIC & Industrial Sites Task Manager \\
\hline Ted Zaferatos & NDEP & Oversight/Representative \\
\hline
\end{tabular}

BN - Bechtel Nevada

NDEP - Nevada Division of Environmental Protection

NNSA/NSO - U.S. Department of Energy, National Nuclear Security Administration Nevada Site Office

SAIC - Science Applications International Corporation

Shaw - Shaw Environmental, Inc. 


\section{A.1.2.4 Develop Conceptual Site Models}

Five CSMs have been developed for CAU 516 using assumptions formulated from the physical setting, historical background, and potential contaminant sources and release information. The applicability of the CSMs to each CAS is summarized in Table A.1-3 and discussed in the following subsections. The CSMs are termed:

- Septic System

- Leachfield

- Clean Out Box

- Dry Well

- $\quad$ Sump

Conceptual site models describe the most probable scenarios for current conditions at specific sites and define the assumptions that are the basis for identifying appropriate sampling strategy and data collection methods. They set the stage for assessing how contaminants could reach receptors both in the present and future by addressing contaminant nature and location, transport mechanisms, and pathways, potential receptors, and potential exposures to those receptors. Accurate CSMs are important as they serve as the basis for all subsequent inputs and decisions throughout the DQO process.

Table A.1-3

Conceptual Site Models and Applicable CASs

\begin{tabular}{|c|c|c|c|c|c|}
\hline $\begin{array}{c}\text { Conceptual Site } \\
\text { Models }\end{array}$ & 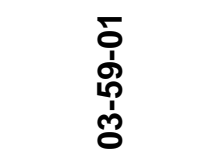 & 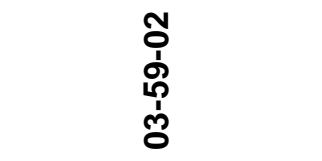 & $\begin{array}{l}\bar{\phi} \\
\frac{1}{10} \\
0 \\
0\end{array}$ & $\begin{array}{l}0 \\
0 \\
1 \\
10 \\
\dot{0} \\
0\end{array}$ & 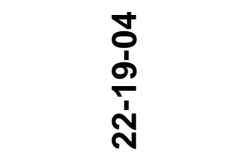 \\
\hline Septic System & $\begin{array}{l}\text { Septic Tank, } \\
\text { Distribution Box, } \\
\text { and Piping }\end{array}$ & $\begin{array}{l}\text { Septic Tank, Distribution } \\
\text { Box, and Piping }\end{array}$ & Sump Piping & $\begin{array}{l}\text { Clean Out Box } \\
\text { Piping }\end{array}$ & --- \\
\hline Leachfield & Leachfield & Leachfield & --- & ---- & --- \\
\hline Clean Out Box & --- & --- & --- & Clean Out Box & \\
\hline Dry Well & --- & $\begin{array}{l}\text { Photographic Dry Well, } \\
\text { LANL Yard Dry Well }\end{array}$ & --- & --- & --- \\
\hline Sump & --- & --- & Sump & --- & $\begin{array}{l}\text { Decontamination } \\
\text { Pad, Drainage } \\
\text { Trench, and Sump }\end{array}$ \\
\hline
\end{tabular}


An important element of a CSM is the expected fate and transport of contaminants, which infer how contaminants move through site media and where they can be expected in the environment. The expected fate and transport is based on distinguishing physical characteristics of the contaminants and media. Contaminant characteristics include solubility, density, and particle size. Media characteristics include permeability, saturation, sorting, chemical composition, and adsorption coefficients. In general, contaminants with low solubility and high density can be expected to be found relatively close to release points. Contaminants with high solubility and low density can be expected to be found further from release points or in areas where settling may occur.

Contaminants migrating to regional aquifers are not considered a likely scenario at CAU 516 based on the average depth to groundwater, the low annual average precipitation rates, the high potential for evapotranspiration, and the low mobility of expected COPCs (e.g., SVOCs, PCBs, petroleum hydrocarbons, and RCRA metals).

The five conceptual site models developed for CAU 516 and the CASs to which they are applicable are summarized in Table A.1-3 and discussed in the following subsections.

\section{A.1.2.4.1 Septic System Conceptual Site Model}

The Septic System CSM applies to the septic tanks, distribution boxes, and associated piping in CASs 03-59-01 and 03-59-02; the discharge pipe leading to the sump in CAS 06-51-01; and the tie-in to the CAS 06-51-03 clean out box. Upon release from the source, the effluent traveled through discharge lines and was routed into the various septic system components. Figure A.1-6 shows a generalized representation of the Septic System CSM. The following discussion of the CSM parameters provides additional details to supplement this model.

Exposure Scenario - The land-use designation for CASs 03-59-01 and 03-59-02 is within the Nuclear and High Explosives Test Zone for additional underground nuclear weapons tests and outdoor high explosive tests. The land-use designation for CASs 06-51-01 and 06-51-03 is within the Nuclear Test Zone reserved for dynamic experiments, hydrodynamic tests, and underground nuclear weapons and weapons effects tests (DOE/NV, 1998). Based on these land-use designations, the potential for exposure to contaminants is limited to construction and industrial workers who may be 

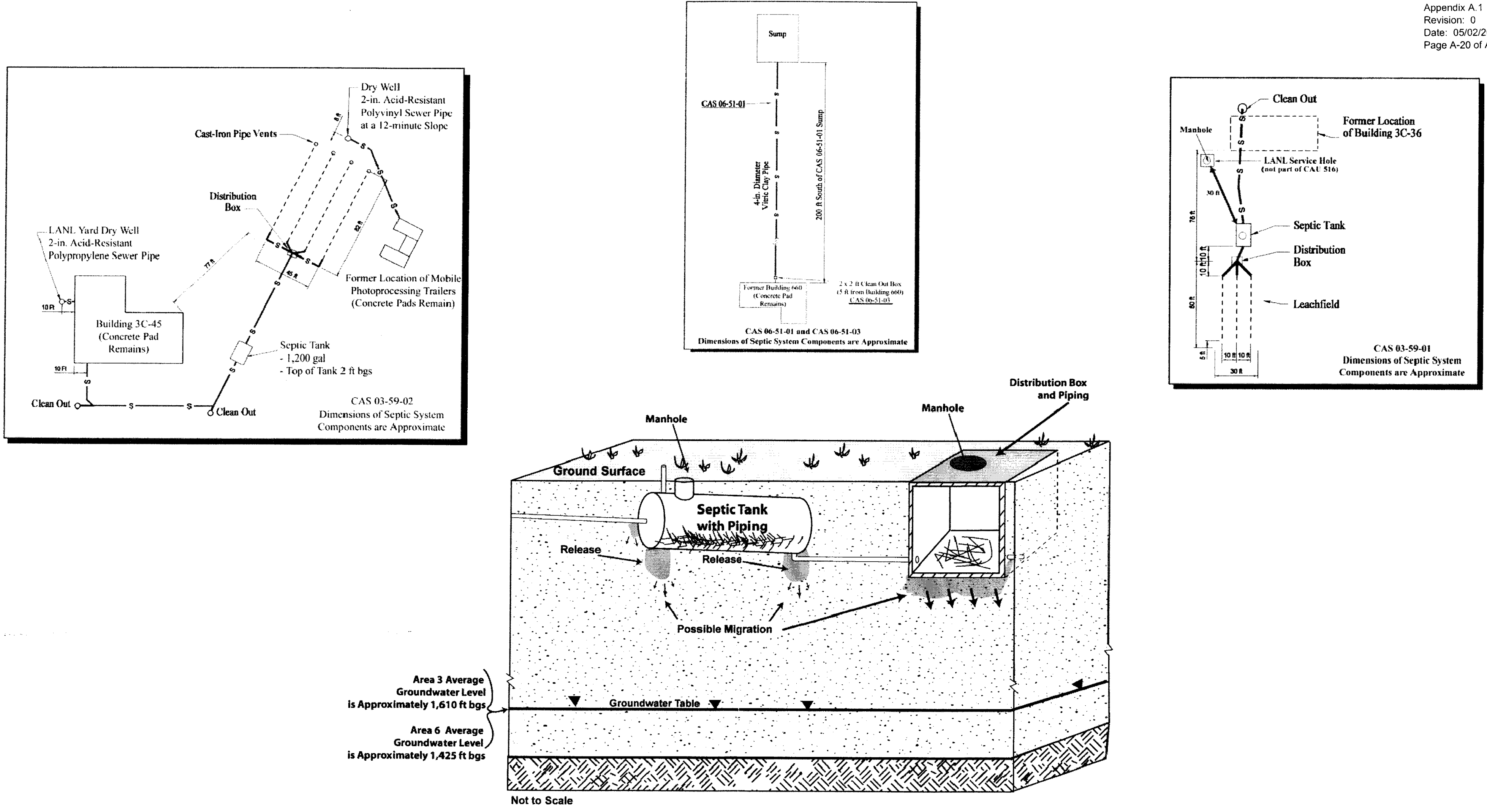

Figure A.1-6

Septic System Conceptual Site Model

Applicable to CAS 03-59-01, CAS 03-59-02, CAS 06-51-01, and CAS 06-51-03 
exposed to COPCs through inadvertent oral ingestion, inhalation, or dermal contact (absorption) of soils and/or debris due to disturbance of these sites.

Affected Media - The affected media are subsurface soils beneath the base of the septic tank, distribution box, and associated piping.

Location of Contamination/Release Points - Beneath the outlet and inlet pipe ends and the base of the septic tanks, beneath the outlet end pipe and the base of the distribution boxes, and beneath any breaches in the associated piping. Migration of contamination would be expected to be primarily downward with horizontal migration to a lesser extent.

CAS 03-59-01 - Release from Building 3C-36 was through one drain leading to a distribution box and exiting into the leachfield.

CAS 03-59-02 - Release from Building 3C-45 was through a discharge pipe exiting the south side of the building. Another release from Building 3C-45 was through a discharge pipe exiting to the west side and leading to a dry well. Also, a release from the mobile photoprocessing trailers to a separate dry well located north of the leachfield.

CAS 06-51-01 - Release from Building 660 was through a 4-in. vitric clay pipe running north and exiting into the sump.

CAS 06-51-03 - Release into the clean out box was through a 6-in. diameter cast-iron pipe entering from the west side of the clean out box. The pipe served as an access point to the discharge pipe that serviced Building 660 and exited into the sump in CAS 06-51-01.

Transport Mechanisms - Injection of effluent and the infiltration and percolation of precipitation through soil serve as driving forces for downward migration.

Preferential Pathways - Preferential pathways for contaminant migration are not expected for this CSM.

Lateral and Vertical Extent of Contamination - The degree of contaminant migration, if any, at these sites is unknown, but it is assumed to be minimal based on the ambient and environmental 
conditions at the NTS such as low precipitation (i.e., 3 to 10 in.), high evapotranspiration (USGS, 1975), and the mobility of COPCs. Any contamination at these sites is expected to be contiguous with the source and decrease with distance and depth from the site. It is not believed that groundwater has been, or would be, impacted because of the significant depths of groundwater levels and local environmental conditions. The average groundwater level in Area 3 is reported at 1,610 ft bgs (Wuellner, 1994), and 1,425 ft in Area 6 (DRI, 1993).

\section{A.1.2.5 Leachfield Conceptual Site Model}

The Leachfield CSM applies to CASs 03-59-01 and 03-59-02. Effluent was dispersed throughout the leachfield by way of perforated distribution pipes. Figure A.1-7 shows a generalized representation of the Leachfield CSM. The following discussion of the CSM parameters provides additional details to supplement this model.

Exposure Scenario - The land-use designation for CASs 03-59-01 and 03-59-02 is within the Nuclear and High Explosives Test Zone for additional underground nuclear weapons tests and outdoor high explosive tests (DOE/NV, 1998). Based on this land-use designation, the potential for exposure to contaminants is limited to construction and industrial workers who may be exposed to COPCs through inadvertent oral ingestion, inhalation, or dermal contact (absorption) of soils and/or debris due to disturbance of these materials.

Affected Media - The affected medium is soil beneath the leachrock/native soil interface.

Location of Contamination/Release Points - The leachfields have multiple distribution lines. If present, soluble contaminants are expected in distal areas of the leachfield; insoluble and large-particle contaminants are expected in the proximal ends.

Transport Mechanisms - Injection of effluent and infiltration and percolation of precipitation through soil serve as driving forces for downward migration.

Preferential Pathways - Preferential pathways for contaminant migration are not expected for this CSM. 


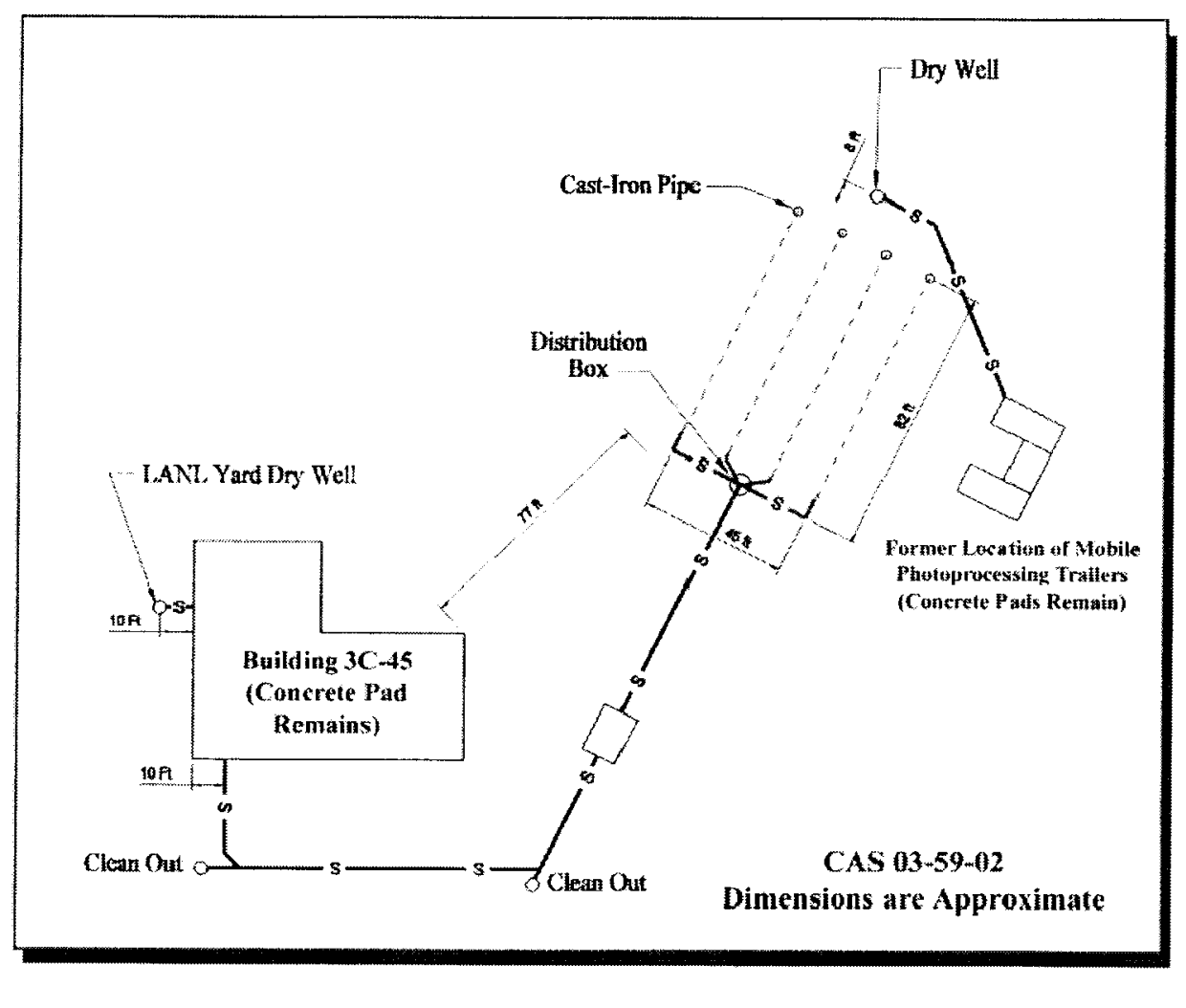

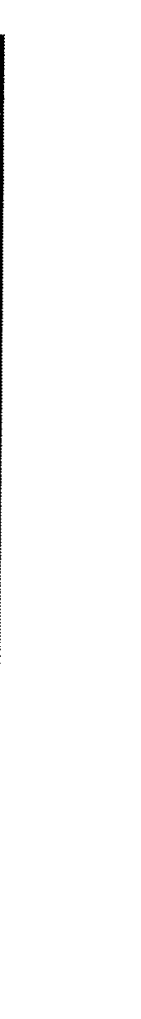
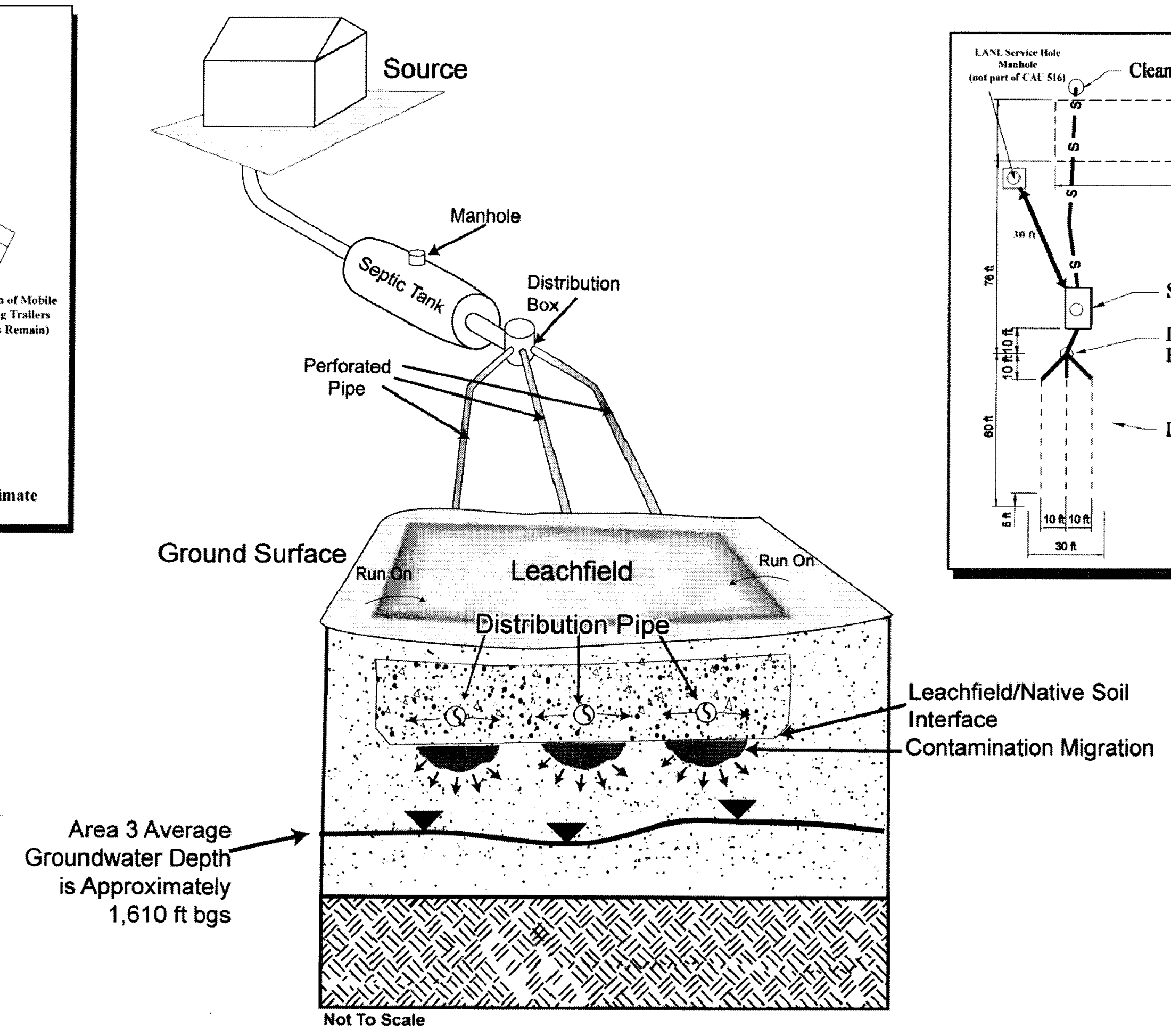

Figure A.1-7

Leachfield Conceptual Site Model

Applicable to CAS 03-59-01 and CAS 03-59-02 
Lateral and Vertical Extent of Contamination - The degree of contaminant migration, if any, at these sites is unknown, but it is assumed to be minimal based on the ambient and environmental conditions at the NTS such as low precipitation (i.e., 3 to 10 in.), high evapotranspiration (USGS, 1975), and the mobility of COPCs. Any contamination at these sites is expected to be contiguous with the source and decrease with distance and depth from the site.

It is not believed that groundwater has been, or would be, impacted because of the significant depths of groundwater levels and local environmental conditions. The average groundwater level in Area 3 is reported at 1,610 ft bgs (Wuellner, 1994).

\section{A.1.2.6 Clean Out Box Conceptual Site Model}

The Clean Out Box CSM applies to CAS 06-51-03. The clean out box provides a single-point access to the main discharge pipe connecting Building 660 to the sump. Figure A.1-8 shows a generalized representation of the Clean Out Box CSM. The following discussion of the CSM parameters provides additional details to supplement this model.

Exposure Scenario - Land-use designation for CAS 06-51-03 is within the Nuclear Test Zone reserved for dynamic experiments, hydrodynamic tests, and underground nuclear weapons and weapons effects tests (DOE/NV, 1998). Based on this land-use designation, the potential for exposure to contaminants is limited to construction and industrial workers who may be exposed to COPCs through inadvertent oral ingestion, inhalation, or dermal contact (absorption) of soils and/or debris due to disturbance of these materials.

Affected Media - The affected medium is subsurface soil beneath the base of the clean out box.

Location of Contamination/Release Points - Contaminants would be expected to be more concentrated beneath the clean out box as a result of one direct release point and subsequent percolation from gravity. Any contamination would be attributable to the release of contaminants through direct release from the outlet pipe into the clean out box.

Transport Mechanisms - Injection of effluent through direct release from the access pipe into the clean out box and the infiltration and percolation of precipitation through soil serve as driving forces for downward migration. 

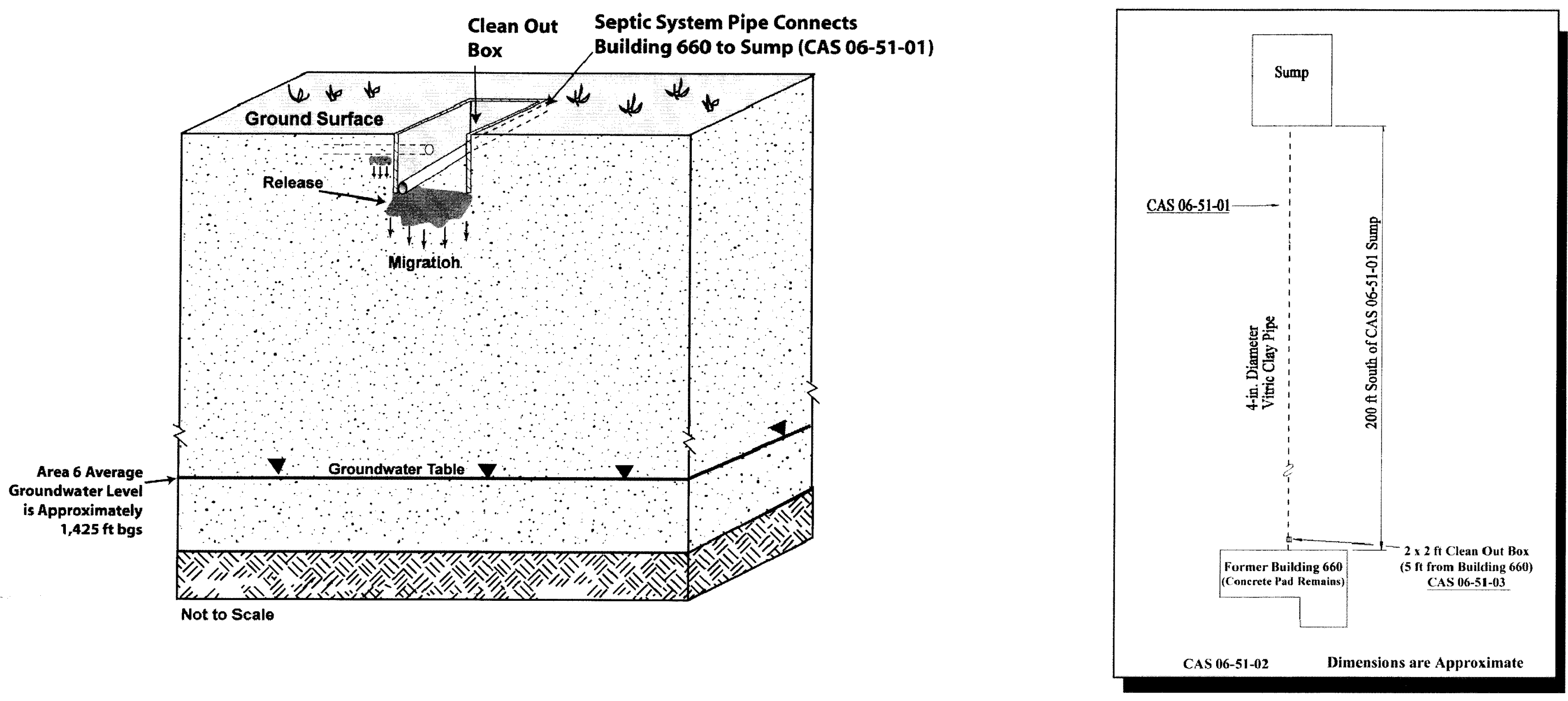

Figure A.1-8

Clean Out Box Conceptual Site Model Applicable to CAS 06-51-03 
Preferential Pathways - Preferential pathways for contaminant migration are not expected for this CSM.

Lateral and Vertical Extent of Contamination - The degree of contaminant migration, if any, at these sites is unknown, but it is assumed to be minimal based on the ambient and environmental conditions at the NTS such as low precipitation (i.e., 3 to $10 \mathrm{in}$.) and high evapotranspiration (USGS, 1975), and the mobility of COPCs. Any contamination at these sites is expected to be contiguous with the source and decrease with distance and depth from the site. It is not believed that groundwater has been or would be impacted because of the significant depths of groundwater levels and local environmental conditions. The average groundwater level in Area 6 is reported at 1,425 ft bgs (Wuellner, 1994).

\section{A.1.2.7 Dry Well Conceptual Site Model}

The Dry Well CSM applies to the dry wells at CAS 03-59-02. Effluent was released through a distribution pipe directly into the dry wells. Figure A.1-9 shows a generalized representation of the Dry Well CSM. The following discussion of the CSM parameters provide additional details to supplement this model.

Exposure Scenario - The CAS 03-59-02 land-use designation is within the Nuclear and High Explosives Test Zone for additional underground nuclear weapons tests and outdoor high explosive tests (DOE/NV, 1998). Based on this land-use designation, the potential for exposure to contaminants is limited to construction and industrial workers who may be exposed to COPCs through inadvertent oral ingestion, inhalation, or dermal contact (absorption) of soils and/or debris due to disturbance of these materials.

Affected Media - The affected medium is subsurface soil beneath the base of the dry wells.

Location of Contamination/Release Points - The dry wells are a single-point source release. Any contaminants at this CAS are expected to beneath the dry wells.

Transport Mechanisms - The injection of wastewater to the dry wells was the primary transport mechanism. Infiltration and percolation through soil is a secondary mechanism that moves contaminants deeper into the soil. 

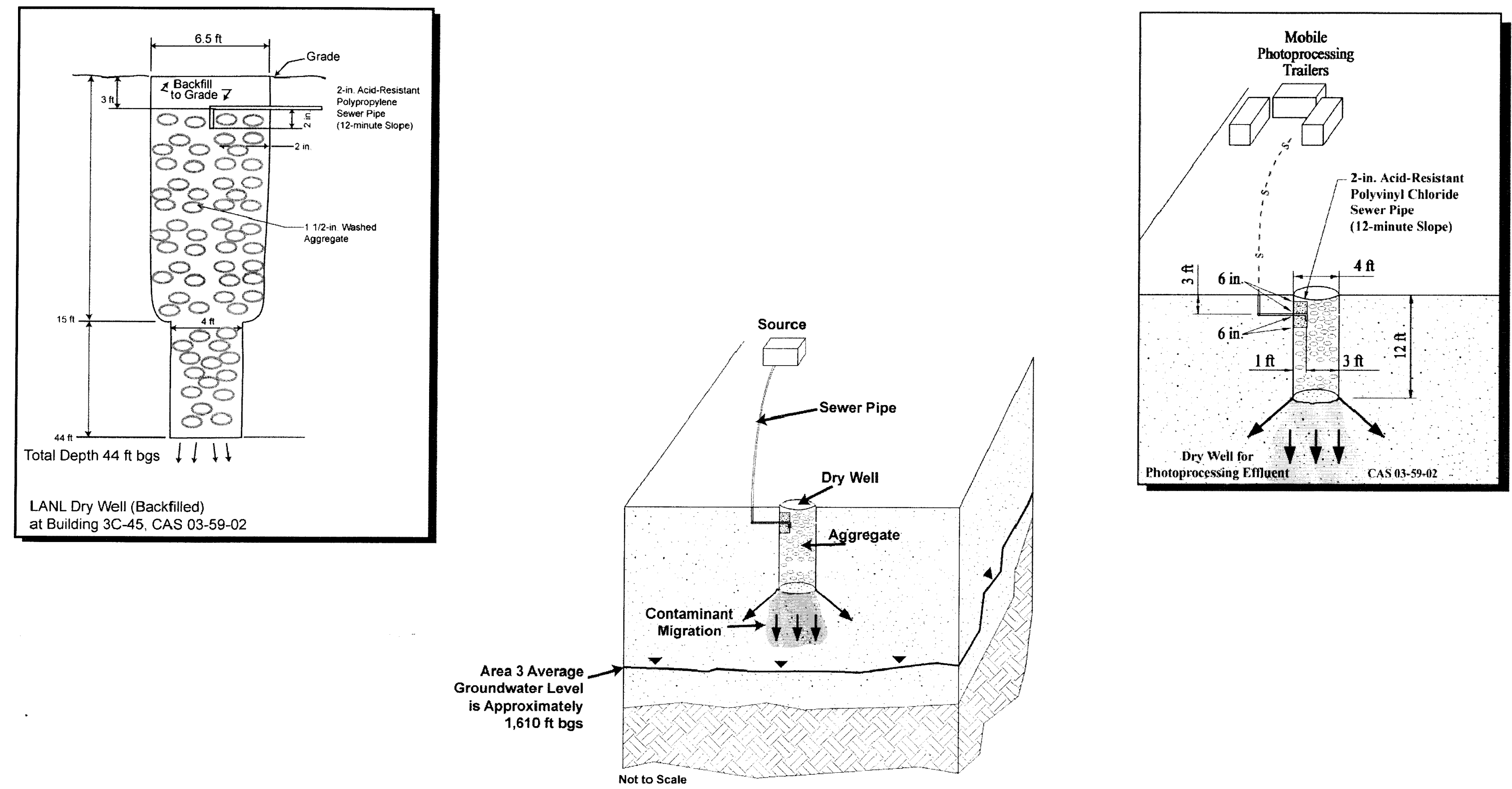

Figure A.1-9

Dry Well Conceptual Site Model

Applicable to CAS 03-59-01 and CAS 03-59-02 
Preferential Pathways - Preferential pathways for contaminant migration are not expected for this CSM.

Lateral and Vertical Extent of Contamination - The degree of contaminant migration at the dry wells are unknown, but it is assumed to be minimal based on the ambient and environmental conditions at the NTS such as low precipitation (i.e., 3 to 10 in.), high evapotranspiration (USGS, 1975), and the mobility of COPCs. Any contamination in the dry wells is expected to be contiguous with the source and decrease with depth and lateral distance from a dry well.

The average groundwater level in Area 3 is 1,610 (Wuellner, 1994); therefore, it is not believed that the groundwater has been or would be impacted by any contamination in the dry wells.

\section{A.1.2.7.1 Sump Conceptual Site Model}

The Sump CSM applies to CASs 06-51-01 and 22-19-04. Figure A.1-10 shows a generalized representation of the Sump CSM. The following discussion of the CSM parameters provides additional details to supplement this model.

Exposure Scenario - The land-use designation for CAS 06-51-01 is within the Nuclear Test Zone reserved for dynamic experiments, hydrodynamic tests, and underground nuclear weapons and weapons effects tests. The land-use designation for CAS 22-19-04 is within the Solar Enterprise Zone (DOE/NV, 1998). This area is designated for the development of a solar power generation facility, and light industrial equipment and commercial manufacturing capability. Based on these land-use designations, the potential for exposure to contaminants are limited to construction and industrial workers in CAS 06-51-01, and to construction, industrial, and commercial workers in CAS 22-19-04 who may be exposed to COPCs through inadvertent oral ingestion, inhalation, or dermal contact (absorption) of soils and/or debris due to disturbance of these materials.

Affected Media - The affected media are soil beneath the sumps and possibly the surrounding surface soil. The sump in CAS 22-19-04 also includes the soil beneath the decontamination pad and trench.

Location of Contamination/Release Points - Contaminants, if present, would be concentrated at the sump material/native soil interface, within low points in the sump, and would be expected to be found at decreasing concentrations along the flow direction of the trench and surface discharge area. 

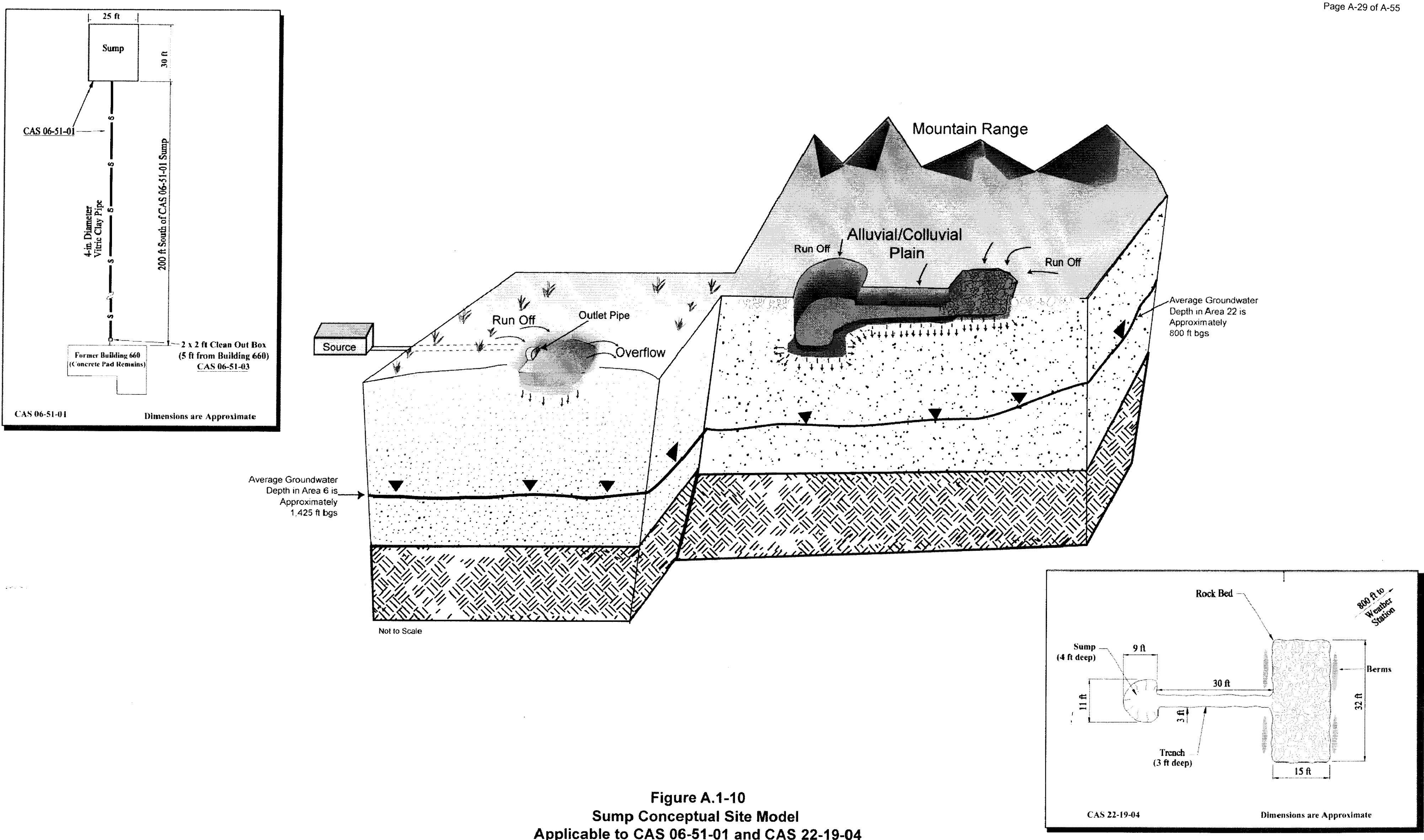
Surface runoff and erosion (e.g., flash flooding) would move contaminated soil laterally, with the concentration decreasing with distance.

Transport Mechanisms - The discharge of wastewater directly onto the surface of the decontamination area components (e.g., decontamination pad, trench, sump) at CAS 22-19-04 and directly into the sump at CAS 06-51-03, and the infiltration and percolating of precipitation into the soil are driving forces for downward migration; however, in the case of CAS 22-19-04, runoff from flash flooding also serves as a transport mechanism moving contamination to low-lying areas adjacent to the sump.

Preferential Pathways - The preferential pathway for contamination migration from the sump at CAS 22-19-04 would be erosion by surface water flow resulting from the perpendicular orientation of the sump on the alluvial/colluvial plain sloping to the south. No preferential pathways for contaminant migration at CAS 06-51-01 were identified.

Lateral and Vertical Extent of Contamination - The degree of contaminant migration at the sumps is unknown, but it is assumed to be minimal based on the ambient and environmental conditions at the NTS such as low precipitation (i.e., 3 to 10 in.), high evapotranspiration (USGS, 1975), and the mobility of COPCs. The average groundwater level in Area 22 is $787 \mathrm{ft}$ (DRI, 1993); therefore, it is not believed that the groundwater has been or would be impacted by any contamination in the sumps.

\section{A.1.3 Step 2 - Identify the Decision}

This step develops a decision statement and defines alternative actions. The following subsections identify decisions and alternative actions appropriate for the investigation.

\section{A.1.3.1 Develop a Decision Statement}

Problem Statement, "There is an insufficient amount of information to characterize the nature and extent of contamination released to these sites to determine if there is a risk to human health and the environment."

The Decision I statement is, "Determine if a COC is present."

The Decision II statement is, "Determine the lateral and vertical extent of a COC." 


\section{A.1.3.2 Alternative Actions to the Decision}

If a COC is not present, further assessment of the CAS is not required. If a COC is present, resolve Decision II.

If the extent of a COC is defined in both the lateral and vertical directions, further assessment of the CAS is not required. If the extent of a COC is not defined, reevaluate site conditions and collect additional samples.

\section{A.1.4 Step 3 - Identify the Inputs to the Decision}

This step identifies the information needed, determines sources for information, determines the basis for establishing the action level, and identifies sampling and analysis methods that can meet the data requirements. To determine if a COC is present, each sample result or population parameter (Section A.1.6.1) is compared to the PAL (Section A.1.4.2). If any sample result or population parameter is greater than the PAL, then the CAS is advanced to Decision II for that analyte. This approach does not use a statistical mean/average for comparison to the PAL, but rather the individual result to identify COCs.

\section{A.1.4.1 Information Needs and Information Sources}

In order to determine if a COC is present at the CAS, sample data must be collected and analyzed following these two criteria: (1) samples must be collected in areas most likely to contain a COC and (2) the analytical suite selected must be sufficient to detect any COCs present in the samples. Biasing factors to support these criteria include:

- Documented process knowledge on source and location of release

- Field observations

- Field-screening results

- Historical sample results

- Experience and data from investigations of similar sites

- Professional judgement

In order to determine the extent of a COC for Decision II, sample data must be collected and analyzed at locations to bound the lateral and vertical extent of COCs. The data required to satisfy the information needed for each COC is a sample result that is below the PAL. Step-out locations will be selected. Samples will only be analyzed for those parameters that exceeded PALs (i.e., COCs) in 
prior samples. Biasing factors to support these information needs may include the factors previously listed and Phase I analytical results.

Table A.1-4 lists the information needs, the source of information for each need, and the proposed methods to collect the data. The last column addresses the QA/QC data type and associated metric. The data type is determined by the intended use of the resulting data in decision making.

Data types are discussed in the following text. All data to be collected are classified into one of three measurement quality categories: quantitative, semiquantitative, and qualitative. The categories for measurement quality are defined below.

\section{Quantitative Data}

Quantitative data results from direct measurement of a characteristic or component within the population of interest. These data require the highest level of QA/QC in collection and measurement systems because the intended use of the data is to resolve the primary decision (i.e., rejecting or accepting the null hypothesis) and/or verifying closure standards have been met. Laboratory analytical data are usually assigned as quantitative data.

\section{Semiquantitative Data}

Semiquantitative data is generated from a measurement system that indirectly measures the quantity or amount of a characteristic or component of interest. Inferences are drawn about the quantity or amount of a characteristic or component because a correlation has been shown to exist between results from the indirect measurement and the quantitative measurement. The QA/QC requirements on semiquantitative collection and measurement systems are high, but may not be as rigorous as a quantitative measurement system. Semiquantitative data contribute to decision making, but are not generally used alone to resolve primary decisions. The data are often used to guide investigations toward quantitative data collection.

\section{Qualitative Data}

Qualitative data identifies or describes the characteristics or components of the population of interest. The QA/QC requirements for qualitative data are the least rigorous on data collection methods and measurement systems. Professional judgement is often used to generate qualitative data. The 
Table A.1-4

Information Needs to Resolve the Phase I and Phase II Decisions

\begin{tabular}{|c|c|c|c|}
\hline $\begin{array}{l}\text { Information } \\
\text { Need }\end{array}$ & Information Source & Collection Method & Data Type/Metric \\
\hline \multicolumn{4}{|c|}{$\begin{array}{l}\text { Decision I: Determine if a COC is present. } \\
\text { Criteria I: Samples must be collected in areas most likely to contain a COC. }\end{array}$} \\
\hline \multirow[t]{5}{*}{$\begin{array}{l}\text { Source and location } \\
\text { of release points }\end{array}$} & $\begin{array}{l}\text { Process knowledge compiled } \\
\text { during the preliminary assessment } \\
\text { process and previous } \\
\text { investigations of similar sites }\end{array}$ & $\begin{array}{l}\text { Information documented in CSM } \\
\text { and public reports - no } \\
\text { additional data needed }\end{array}$ & $\begin{array}{l}\text { Qualitative - CSM has not been } \\
\text { shown to be inaccurate }\end{array}$ \\
\hline & Site visit and field observations & $\begin{array}{l}\text { Conduct site visits and } \\
\text { document field observations }\end{array}$ & $\begin{array}{l}\text { Qualitative - CSM has not been } \\
\text { shown to be inaccurate }\end{array}$ \\
\hline & Aerial photographs & $\begin{array}{l}\text { Review and interpret aerial } \\
\text { photographs }\end{array}$ & $\begin{array}{l}\text { Semiquantitative - Sampling based } \\
\text { on biasing criteria stipulated in } \\
\text { DQO Step } 3\end{array}$ \\
\hline & Radiological surveys & $\begin{array}{l}\text { Review and interpret } \\
\text { radiological surveys }\end{array}$ & $\begin{array}{l}\text { Semiquantitative - Sampling based } \\
\text { on biasing criteria stipulated in } \\
\text { DQO Step } 3\end{array}$ \\
\hline & Field screening & $\begin{array}{l}\text { Review and interpret } \\
\text { field-screening results }\end{array}$ & $\begin{array}{l}\text { Semiquantitative - Sampling based } \\
\text { on biasing criteria stipulated in } \\
\text { DQO Step } 3\end{array}$ \\
\hline \multicolumn{4}{|c|}{$\begin{array}{l}\text { Decision I: Determine if a COC is present. } \\
\text { Criteria 2: Analyses must be sufficient to detect any COCs in samples. }\end{array}$} \\
\hline $\begin{array}{l}\text { Identification of all } \\
\text { potential } \\
\text { contaminants }\end{array}$ & $\begin{array}{l}\text { Process knowledge compiled } \\
\text { during the preliminary assessment } \\
\text { process and previous } \\
\text { investigations of similar sites }\end{array}$ & $\begin{array}{l}\text { Information reported in CSM } \\
\text { and public reports - no } \\
\text { additional data needed }\end{array}$ & $\begin{array}{l}\text { Qualitative - CSM has not been } \\
\text { shown to be inaccurate }\end{array}$ \\
\hline Analytical results & Data packages of biased samples & $\begin{array}{l}\text { Appropriate sampling } \\
\text { techniques and approved } \\
\text { analytical methods will be used }\end{array}$ & $\begin{array}{l}\text { Quantitative - Detection limits will } \\
\text { be less than or equal to PALs }\end{array}$ \\
\hline \multicolumn{4}{|c|}{ Decision II: Determine the lateral and vertical extent of a COC. } \\
\hline $\begin{array}{l}\text { Identification of } \\
\text { applicable COCs }\end{array}$ & Data packages of prior samples & $\begin{array}{l}\text { Review analytical results to } \\
\text { select COCs }\end{array}$ & $\begin{array}{l}\text { Quantitative - Only COCs } \\
\text { identified will be analyzed in future } \\
\text { sampling events }\end{array}$ \\
\hline \multirow[t]{3}{*}{$\begin{array}{l}\text { Extent of } \\
\text { Contamination }\end{array}$} & Field observations & Document field observations & $\begin{array}{l}\text { Qualitative - CSM has not been } \\
\text { shown to be inaccurate }\end{array}$ \\
\hline & Field screening & $\begin{array}{l}\text { Conduct field screening with } \\
\text { appropriate instrumentation }\end{array}$ & $\begin{array}{l}\text { Semiquantitative - FSRs will be } \\
\text { compared to FSLs }\end{array}$ \\
\hline & Phase I analytical results & $\begin{array}{l}\text { Appropriate sampling } \\
\text { techniques and approved } \\
\text { analytical methods will be used } \\
\text { to bound COCs }\end{array}$ & $\begin{array}{l}\text { Quantitative - Validated analytical } \\
\text { results will be compared to PALs } \\
\text { to determine COC extent }\end{array}$ \\
\hline
\end{tabular}


intended use of the data is for information purposes, to refine conceptual models, and to guide investigations rather than resolve primary decisions. This measurement of quality is typically associated with historical information and data where QA/QC may be highly variable or not known. Metrics provide a tool to determine if the collected data support decision making as intended. Metrics tend to be numerical for quantitative and semiquantitative data, and descriptive for qualitative data.

\section{A.1.4.2 Determine the Basis for the Preliminary Action Levels}

Industrial site workers and construction/remediation workers may be exposed to contaminants through oral ingestion, inhalation, external (radiological), or dermal contact (absorption) of soil during disturbance of this media. Laboratory analytical results for soils will be compared to the following PALs to evaluate if COPCs are present at levels that may pose an unacceptable risk to human health and/or the environment:

- EPA Region IX Risk-Based Preliminary Remediation Goals for Industrial Soils (EPA, 2002).

- Background concentrations for metals are considered when natural background exceeds the PRG, as is often the case with arsenic. Background is considered the mean plus two times the standard deviation of the mean for sediment samples collected by the Nevada Bureau of Mines and Geology throughout the Nevada Test and Training Range (formerly the Nellis Air Force Range) (NBMG, 1998; Moore, 1999).

- TPH action level of $100 \mathrm{mg} / \mathrm{kg}$ per the NAC 445A.2272 (NAC, 2002).

- The PALs for radionuclides are isotope-specific and defined as the maximum concentration for the isotope found in samples from undisturbed background locations in the vicinity of the NTS (McArthur and Miller, 1989; US Ecology and Atlan-Tech, 1991; and DOE/NV, 1996).

\section{A.1.4.3 Potential Sampling Techniques and Appropriate Analytical Methods}

\section{Field Screening}

Field-screening activities may be conducted for the following analytes and/or parameters:

- Silver - X-ray fluorescence, or equivalent method, may be used at the CAS 03-59-02 dry well where photoprocessing chemicals were disposed.

- Alpha and Beta/Gamma Radiation - Handheld radiological survey equipment may be used at CAS 03-59-02 based on nuclear racks used for nuclear tests diagnostics that were stored at Building C3-45, CASs 06-51-01 and 06-51-03, because radiological contaminants were 
detected in the CAU 330 UST and in the decontamination rinsate decontamination activities conducted at CAS 22-19-04. Field screening using handheld radiological survey equipment may also be used at CAS 03-59-01 due to its location in a forward area and uncertainty regarding activities that occurred there.

- Gamma Radiation - Gamma spectrometry, or an equivalent instrument or method, may be used at CAS 03-59-01 and CAS 03-59-02 based on previous radiological surveys and analytical results that detected radiological activity at concentrations less than PALs. Gamma radiation may also be field screened at CAS 22-19-04 based on the exposure of vehicles and personnel to gamma radiation during near-field observations of nuclear tests.

- VOCs - A photoionization detector, or an equivalent instrument or method, may be used to conduct headspace analysis at all CASs because VOCs are representative of general characteristics of sewage and may have been released by decontamination activities once conducted at CAS 22-19-04.

- $T P H$ - A gas chromatograph, or equivalent equipment or method, may be used at all the CASs because TPH is representative of general characteristics of sewage and may have been in the decontamination rinsate from decontamination activities conducted at CAS 22-19-04. Total petroleum hydrocarbons were detected at $191 \mathrm{mg} / \mathrm{kg}$ in the CAS 06-04-02 UST located within the boundaries of CAS 06-51-01 and CAS 06-51-03.

Based on the results of previous CAU investigations and common NTS practices, the aforementioned field-screening techniques may be applied to all the CASs with the exception of silver field screening. These field-screening techniques will provide semiquantitative data that can be used to guide soil sampling activities.

\section{Soil Sampling}

Auguring, direct-push, excavation, drilling, grab sampling by hand, or other appropriate sampling methods will be used to collect soil samples for laboratory analysis. Sample collection and handling activities will be conducted in accordance with the contractor's approved procedures.

The CAIP provides the analytical methods and laboratory performance requirements (e.g., detection limits, precision, and accuracy) to be followed in Section 3.0 and Section 6.0, respectively. Sample volumes are laboratory- and method-specific and will be determined in accordance with laboratory requirements. Specific analyses required for the disposal of IDW are identified in Section 4.2.5 of this CAIP. 
The analyses to be conducted for samples collected for this CAU are listed in Table A.1-5. The analyses reports VOCs, SVOCs, petroleum hydrocarbons, PCBs, metal compounds, and radionuclides included in Table A.1-6.

Table A.1-5

Analytical Methods for Laboratory Analysis

\begin{tabular}{|c|c|c|}
\hline \multirow{2}{*}{ Analytical Parameter } & \multicolumn{2}{|c|}{ Analytical Method } \\
\hline & Liquid & Soil/Sediment/Sludge \\
\hline Total Volatile Organic Compounds & SW-846 8260B ${ }^{a}$ & $S W-8468260 B^{a}$ \\
\hline $\begin{array}{l}\text { Total Semivolatile Organic Compounds (including } \\
\text { Hydroquinone at CAS 03-59-02 photoprocessing dry well) }\end{array}$ & SW-846 $8270 C^{a}$ & SW-846 $8270 C^{a}$ \\
\hline Total RCRA Metals, plus beryllium and aluminum & $\begin{array}{l}\mathrm{SW}-8466010 \mathrm{~B}^{\mathrm{a}} \\
\left(\text { mercury }-7470 \mathrm{~A}^{\mathrm{a}}\right)\end{array}$ & $\begin{array}{l}\text { SW-846 6010B } \\
\left(\text { mercury }-7471 A^{a}\right)\end{array}$ \\
\hline Polychlorinated Biphenyls & SW-846 $8082^{\mathrm{a}}$ & SW-846 $8082^{a}$ \\
\hline Total Petroleum Hydrocarbons $\left(\mathrm{C}_{6}-\mathrm{C}_{38}\right)$ & SW-846 8015B ${ }^{\mathrm{a}}$ (modified) & SW-846 8015B ${ }^{\mathrm{a}}$ (modified) \\
\hline $\begin{array}{l}\text { Gamma Spectrometry (to include Cesium-137 and } \\
\text { Americium-241) }\end{array}$ & EPA Procedure $901.1^{\mathrm{b}}$ & HASL-300 ${ }^{c}$ \\
\hline Strontium-90 & ASTM D5811-00 ${ }^{d}$ & HASL-300 ${ }^{c}$ \\
\hline Isotopic Plutonium & ASTM D3865-02 & ASTM C1001-00 \\
\hline Isotopic Uranium & ASTM D3972-02 ${ }^{g}$ & ASTM C1000-02h \\
\hline
\end{tabular}

ASTM $=$ American Society of Testing and Materials

RCRA = Resource Conservation and Recovery Act

$\mathrm{SW}=$ Solid Waste

${ }^{a}$ EPA Test Methods for Evaluating Solid Waste, Physical/Chemical Methods, 3rd Edition, Parts 1-4, SW-846 (EPA, 1996)

${ }^{\mathrm{b}}$ Prescribed Procedure for Measurements of Radioactivity in Drinking Water (EPA, 1980)

${ }^{\mathrm{c}}$ The Procedures Manual of the Environmental Measurements Laboratory, HASL-300 (DOE, 1997)

${ }^{d}$ Standard Test Method for Strontium-90 in Water (ASTM, 2000b)

${ }^{\mathrm{e}}$ Standard Test Method for Plutonium in Water (ASTM, 2002b)

${ }^{\dagger}$ Standard Test Method for Radiochemical Determination of Plutonium in Soil by Alpha Spectroscopy (ASTM, 2000a)

${ }^{9}$ Standard Test Method for Isotopic Uranium in Water by Radiochemistry (ASTM, 2002a)

${ }^{\mathrm{h}}$ Standard Test Method for Radiochemical Determination of Uranium Isotopes in Soil by Alpha Spectrometry (ASTM, 2002c)

\section{A.1.5 Step 4 - Define the Boundaries of the Study}

The purpose of this step is to define the target population of interest, specify the spatial and temporal features of the population that are pertinent for decision making, determine practical constraints on data collection, and define the scale of decision making relevant to target populations for Phase I and Phase II decisions. 
Table A.1-6

Analytes for CAU 516

\begin{tabular}{|c|c|c|c|c|c|}
\hline $\begin{array}{l}\text { Volatile Organic } \\
\text { Compounds }\end{array}$ & $\begin{array}{c}\text { Semi-Volatile Organic } \\
\text { Compounds }\end{array}$ & $\begin{array}{c}\text { Total } \\
\text { Petroleum } \\
\text { Hydrocarbons }\end{array}$ & $\begin{array}{l}\text { Polychlorinated } \\
\text { Biphenyls }\end{array}$ & Metals & Radionuclides \\
\hline $\begin{array}{l}\text { 1,1,1-Trichloroethane } \\
\text { 1,1,2,2-Tetrachloroethane } \\
\text { 1,1,2-Trichloroethane } \\
\text { 1,1-Dichloroethane } \\
\text { 1,1-Dichloroethene } \\
\text { cis-1,2-Dichloroethene } \\
\text { cis-1,3-Dichloropropene } \\
\text { trans-1,2-Dichloroethene } \\
\text { 1,2-Dichloroethane } \\
\text { 1,2-Dichloropropane } \\
\text { 2-Butanone } \\
\text { 2-Hexanone } \\
\text { 4-Methyl-2-pentanone } \\
\text { Acetone } \\
\text { Benzene } \\
\text { Bromochloromethane } \\
\text { Bromodichloromethane } \\
\text { Bromoform } \\
\text { Bromomethane } \\
\text { Carbon disulfide } \\
\text { Carbon tetrachloride } \\
\text { Chlorobenzene } \\
\text { Chloroethane } \\
\text { Chloroform } \\
\text { Chloromethane } \\
\text { Dibromochloromethane } \\
\text { Ethylbenzene } \\
\text { Methyl tertiary butyl ether } \\
\text { Methylene chloride } \\
\text { Styrene } \\
\text { Tetrachloroethene } \\
\text { Toluene } \\
\text { trans 1,3-Dichloropropene } \\
\text { Trichloroethene } \\
\text { Vinyl acetate } \\
\text { Vinyl chloride } \\
\text { Xylene }\end{array}$ & 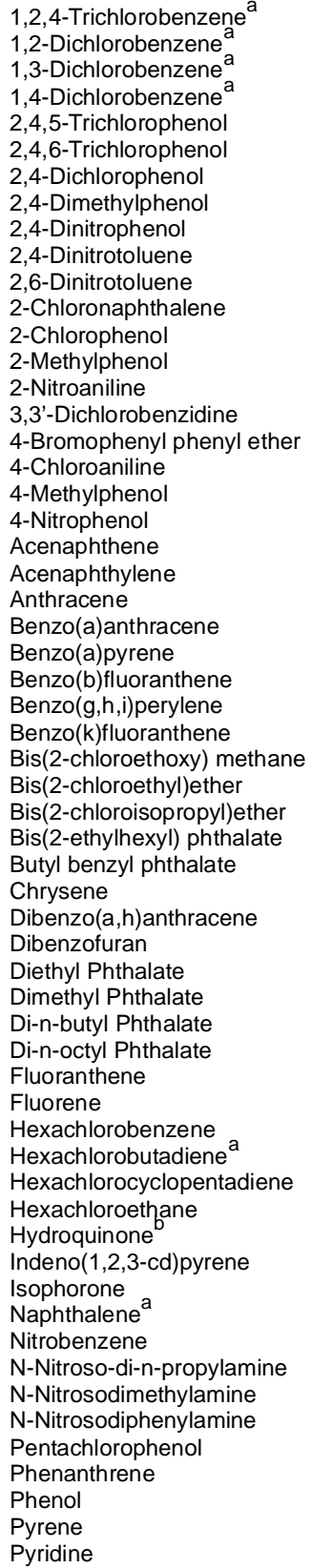 & $\begin{array}{l}\text { Total Petroleum } \\
\text { Hydrocarbons } \\
{\left[\mathrm{C}^{6}-\mathrm{C}^{38}\right]}\end{array}$ & $\begin{array}{l}\text { Aroclor-1016 } \\
\text { Aroclor-1221 } \\
\text { Aroclor-1232 } \\
\text { Aroclor-1242 } \\
\text { Aroclor-1248 } \\
\text { Aroclor-1254 } \\
\text { Aroclor-1260 }\end{array}$ & $\begin{array}{l}\text { Arsenic } \\
\text { Barium } \\
\text { Cadmium } \\
\text { Chromium } \\
\text { Lead } \\
\text { Mercury } \\
\text { Selenium } \\
\text { Silver } \\
\text { Plus: } \\
\text { Aluminum } \\
\text { Beryllium }\end{array}$ & $\begin{array}{l}\text { Americum-241 } \\
\text { Cesium-137 } \\
\text { Plutonium-238 } \\
\text { Plutonium-239/240 } \\
\text { Strontium-90 } \\
\text { Uranium-234 } \\
\text { Uranium-235 } \\
\text { Uranium-238 }\end{array}$ \\
\hline
\end{tabular}

${ }^{\mathrm{a}}$ May be reported with VOCs

${ }^{\mathrm{b}} \mathrm{A}$ study is currently being conducted by the laboratory to determine the minimum detection limit. 


\section{A.1.5.1 Define the Target Population}

Decision I target populations represent locations within the CAS that contain COCs, if present. Decision II target populations are locations adjacent to the COC plume where COC concentrations are less than PALs.

\section{A.1.5.2 Identify the Spatial and Temporal Boundaries}

The spatial boundaries that apply to the CASs in Phase I are the sample locations selected for Phase I. In general, geographic boundaries are defined by the impacted soil. Intrusive activities are not intended to extend into the boundaries of neighboring areas of environmental concern (e.g., other CASs). With the exception of CASs 06-51-01 and 06-51-03, the spatial boundaries that apply to Phase II activities will be $100 \mathrm{ft}$ laterally and $50 \mathrm{ft}$ bgs vertically. The spatial boundary of the sump piping in CAS 06-51-01 is reduced laterally and vertically by the UST that comprises CAU 330, CAS 06-51-01, located directly west of the sump piping and midway between Building 660 and the sump. The spatial boundary of the clean out box and pipe that comprises CAS 06-51-03 is also reduced laterally and vertically by the same UST located approximately $50 \mathrm{ft}$ directly north.

Temporal boundaries are those time constraints set up by weather conditions and project schedules. Significant temporal constraints due to weather conditions are not expected. Moist weather may place constraints on sampling and field screening contaminated soils because of the attenuating effect of moisture in samples (e.g., alpha-emitting radionuclides). There are no time constraints on collecting samples as environmental conditions at all sites will not significantly change in the near future and conditions would have stabilized over the years since the sites were last used.

\section{A.1.5.3 Identify Practical Constraints}

Practical constraints include underground and overhead utilities, rough terrain, access restrictions such as scheduling conflicts at the NTS, posted contamination area requirements, physical barriers (e.g., fences, steep slopes), and areas requiring authorized access. Underground utilities surveys will be conducted at each CAS prior to the start of investigation activities to determine if utilities exist, and, if so, determine the limit of spatial boundaries for intrusive activities. No other practical constraints have been identified. 


\section{A.1.5.4 Define the Scale of Decision Making}

The scale of decision making in Phase I is defined as each CAS. The scale of decision making in Phase II is defined as a contiguous area contaminated with any COC.

\section{A.1.6 Step 5 - Develop a Decision Rule}

This step integrates outputs from the previous step with the inputs developed in this step into a decision rule ("If..., then...") statement. This rule describes the conditions under which possible alternative actions would be chosen.

\section{A.1.6.1 Specify the Population Parameter}

The population parameter for Phase I data collected from biased sample locations is the maximum observed concentration of each COC within the target population.

The population parameter for Phase II will be the observed concentration of each unbounded COC in any sample.

\section{A.1.6.2 Choose an Action Level}

Action levels are defined as those PALs listed in Section A.1.4.2.

\section{A.1.6.3 Decision Rule}

If the population parameter of any COPC in a target population exceeds the PAL for the COPC during Phase I, then that COPC is identified as a COC and Phase II sampling will be conducted. If the Site Supervisor determines that sufficient indicators (e.g., staining) are present, then Phase II sampling will also be conducted. If all COPC concentrations are less than the corresponding PALs, then the decision will be no further action.

Sample analyses conducted during this investigation will be sufficient to characterize the contents, if any, of a septic tank for clean closure according to the NAC.

If the observed population parameter of any COC in a sample exceeds the PALs during Phase II, then additional samples will be collected to define the extent. If all observed COC population parameters 
are less than PALs, then the decision will be that the extent of contamination has been defined in the lateral and/or vertical direction(s).

If contamination is inconsistent with the CSM or extends beyond the spacial boundaries, then work will be suspended and the investigation strategy will be reevaluated. If contamination is consistent with the CSM and is within spatial boundaries, then the decision will be to continue sampling to define the extent.

\section{A.1.7 Step 6 - Specify the Tolerable Limits on Decision Errors}

The sampling approach for Phases I and II relies on biased sampling locations; therefore, statistical analysis is not appropriate. Only validated analytical results (quantitative data) will be used to determine if COCs are present (Phase I) or the extent of a COC (Phase II), unless otherwise stated. The baseline condition (i.e., null hypothesis) and alternative condition for Phase I are:

- $\quad$ Baseline condition - A COC is present.

- Alternative condition - A COC is not present.

The baseline condition (i.e., null hypothesis) and alternative condition for Phase II are:

- Baseline condition - The extent of a COC has not been defined.

- Alternative condition - The extent of a COC has been defined.

Decisions and/or criteria have an alpha (false rejection) or beta (false acceptance) error associated with their determination (discussed in the following subsections). Since quantitative data are individually compared to action levels, statistical evaluations of the data such as averages or confidence intervals are not appropriate.

\section{A.1.7.1 False Rejection Decision Error}

The false rejection (alpha) decision error would mean:

- Deciding in Phase I that a COC is not present when it is, or

- Deciding in Phase II that the extent of a COC has been defined when it has not.

In both cases, the consequence is the increased risk to human health and the environment. 
In Phase I, a false rejection decision error (where consequences are more severe) is controlled by meeting these criteria: (1) having a high degree of confidence that the sample locations selected will identify COCs if present anywhere within the CAS, and (2) having a high degree of confidence that analyses conducted will be sufficient to detect any COCs present in the samples. This error is reduced in Phase II by: (1) having a high degree of confidence that the sample locations selected will identify the extent of COCs; (2) having a high degree of confidence that analyses conducted will be sufficient to detect any COCs present in the samples; and (3) having a high degree of confidence that the dataset is of sufficient quality and completeness.

To satisfy the first criterion, Phase I data and samples will be collected in areas most likely to be contaminated by any COCs. In Phase II, data collection will sample areas that represent the lateral and vertical extent of contamination. The following characteristics are considered during both phases to accomplish the first criterion:

- Source and location of release

- Chemical nature and fate properties

- Physical transport pathways and properties

- Hydrologic drivers

These characteristics were considered during the development of the CSMs and selection of sampling locations. The biasing factors listed in Section A.1.4.1 will be used to further ensure that these criteria are met.

To satisfy the second criterion, all Phase I samples will be analyzed for the chemical and radiological parameters listed in Table A.1-1. Phase II samples will be analyzed for those chemical and radiological parameters that identified unbounded COCs.

To satisfy the third criterion, the entire dataset, as well as individual sample results, will be assessed against the DQIs of precision, accuracy, comparability, completeness, and representativeness defined in the Industrial Sites QAPP (NNSA/NV, 2002). The goal for the DQI of completeness is that 90 percent of the critical COPC results are valid for every sample. Critical COPCs are defined as those contaminants that are known or expected to be present within a CAS. In addition, sensitivity has been included as a DQI for laboratory analyses. Site-specific DQIs are discussed in more detail in 
Section 6.0 of the CAIP. Strict adherence to established procedures and QA/QC protocol also protects against false negatives.

\section{A.1.7.2 False Acceptance Decision Error}

The false acceptance (beta) decision error would mean deciding that a COC is present when it is not or a COC is unbounded when it is, resulting in increased costs for unnecessary characterization.

The false acceptance decision error is controlled by protecting against false positive analytical results. False positive results are typically attributed to laboratory and/or sampling/handling errors. Quality assurance/quality control samples such as field blanks, trip blanks, laboratory control samples, and method blanks are used to determine if a false positive analytical result may have occurred. Other measures include proper decontamination of sampling equipment and using certified clean sample containers to avoid cross contamination.

\section{A.1.7.3 Quality Assurance/Quality Control}

Radiological survey instruments and field-screening equipment will be calibrated and checked in accordance with the manufacturer's instructions or approved procedures.

Quality control samples will be collected as required by the Industrial Sites QAPP (NNSA/NV, 2002) and in accordance with established procedures. The required QC samples include:

- Trip blanks (1 per sample cooler containing VOC environmental samples)

- Equipment blanks (1 per sampling event for each type of decontamination procedure)

- Source blanks (1 per source lot per sampling event)

- Field duplicates (minimum of 1 per matrix per 20 environmental samples)

- Field blanks (minimum of 1 per 20 environmental samples)

- MS/MSD (minimum of 1 each per matrix per 20 environmental samples), as required by the analytical method

Additional QC samples may be submitted based on site conditions. 


\section{A.1.8 Step 7 - Optimize the Design for Obtaining Data}

Intrusive soil sampling for field screening and laboratory analysis will be conducted at CAU 516. Biased locations are determined based on biasing factors listed in Section A.1.4.1. The Site Supervisor has the discretion to modify the biased locations, but only if the modified locations meet the decision needs and criteria stipulated in Section A.1.3. The following sections provide the general approach for obtaining the information necessary to resolve Phase I and Phase II decisions.

\section{A.1.8.1 Intrusive Investigation}

Intrusive investigations will be conducted at CAU 516 to resolve the decision statements discussed in Section A.1.3. Drilling, direct-push, excavation, or other appropriate soil collection techniques will be used at select sample locations to collect soil samples for laboratory analysis. Biased locations for these activities are determined based on the biasing factors listed in Section A.1.4.1.

Phase II step-out locations at each CAS will be selected based on the outer boundary sample locations where COCs were detected, other biasing factors listed in Section A.1.4.1, and ambient and site conditions. If biasing factors indicate COCs extend beyond Phase II sample locations, further step-out locations may be necessary. If the step-out locations from different original locations approach each other, then the Site Supervisor may consider this as one area and collect samples only in an outward direction. In general, samples submitted for off-site laboratory analysis would be those that define the lateral and vertical extent of COCs.

The Site Supervisor has the discretion of modifying or replacing the biased sample locations based on biasing factors or Phase I analytical results. The proposed sample locations are discussed in the following sections.

Some of the CASs have vegetation and miscellaneous debris that will need to be moved and/or staged during site preparation activities to facilitate the investigation. Details for preparing sites for investigation will be provided by the A-E contractor to the $\mathrm{M} \& \mathrm{O}$ contractor prior to the start of the investigation. 


\section{A.1.8.1.1 Septic System}

Piping is a septic system component in all the CASs with the exception of CASs 06-51-02 and 22-19-04. Phase I activities at these CASs will consist of excavating to locate the discharge pipes, visually inspecting the pipes for residual material, and collecting biased samples related to the operation of the septic system. Samples will be submitted for laboratory analysis from the following target population:

- COC concentrations in residual material in the septic system piping, if present

- COC concentrations in the soil beneath any detectable breaches in the septic system piping

The CASs 03-59-01 and 03-59-02 each have a septic tank. Phase I activities at these CASs will consist of excavating to locate the septic tank, inspecting inside the septic tank, and collecting biased samples for laboratory analysis from the following target populations:

- COC concentrations in the content of the septic tanks, if present

- COC concentrations in the soil underneath the inlet and outlet end pipes of the septic tanks

- COC concentrations in the soil horizon underlying the base of the septic tank ends

The CASs 03-59-01 and 03-59-02 each have one distribution box where the effluent is directed to a leachfield. Phase I activities at these CASs will consist of excavating to locate the distribution boxes, inspecting inside the distribution boxes, and collecting biased samples for laboratory analysis from the following target populations:

- COC concentrations in the content of the distribution boxes, if present

- COC concentrations in the soil horizon underlying the base of the distribution boxes

\section{A.1.8.1.2 Leachfield}

The CASs 03-59-01 and 03-59-02 each have a leachfield. Phase I activities at these CASs will consist of excavating to locate the boundaries of each leachfield, exposing the midpoint, and the proximal and distal ends of the associated perforated distribution pipes, and collecting biased samples for laboratory analysis from the following target populations:

- COC concentrations in the soil beneath the leachrock/native soil interface at the midpoint, and proximal and distal ends of the distribution pipes. If the interface cannot be identified, then samples will be collected directly beneath the distribution pipes. 


\section{A.1.8.1.3 Clean Out Box}

The clean out box in CAS 06-51-03 is located directly east of the discharge pipe in CAS 06-51-01. Phase I activities at this CAS will consist of using excavation and/or hand tools to determine the relationship of the clean out box and access pipe to the discharge pipe in CAS 06-51-01, and to collect biased samples for laboratory analysis from the following target populations:

- COC concentrations in the residual material in the clean out box, if present

- COC concentrations in soil underneath the access pipe into the clean out box

- COC concentrations in the soil horizon underlying the base of the clean out box

\section{A.1.8.1.4 Dry Well}

Corrective Action Site 03-59-02 has a dry well located $8 \mathrm{ft}$ northeast of the leachfield for disposal of photographic waste and a dry well connected to Building 3C-45 by a sewer line. Phase I activities will consist of confirming the presence of the dry wells and collecting samples for laboratory analysis from the following target populations:

- COC concentrations of residual material in the dry wells, if present

- COC concentrations in the soil at the leachrock/native soil interface of the dry wells

If the interface is not distinguishable, a sample will be collected at the base as shown in as-built engineering drawings, if available.

\section{A.1.8.1.5 Sump}

The CAS 22-19-04 consists of a vehicle decontamination pad, trench, and sump. Phase I activities at this CAS will consist of locating the base of the sump via excavation and collecting biased samples for laboratory analysis from the following target populations:

- COC concentrations at the rock bed/native soil interface at the center and northwest and southwest ends of the decontamination pad

- Soil at midpoint of trench between pad and sump

- COC concentrations in the soil at the lowest point in the sump 
The CAS 06-51-03 includes a sump. Phase I activities will consist of collecting a biased soil sample from the lowest point in the sump and other locations, if appropriate, based on biasing factors.

\section{A.1.8.2 Analytical Program}

All samples will be submitted for off-site analysis that are collected from within the septic system piping, septic tanks, distribution boxes, and clean out boxes with a solid, impermeable base (e.g., concrete). If contamination is detected by field screening, the sample with the highest contamination concentration will be submitted. Any samples exceeding FSLs will have at least one additional sample (i.e., confirmatory sample) submitted to confirm contamination is less than PALs.

\section{A.1.8.3 Additional Sample Collection}

Additional samples may be collected and analyzed to obtain data for the purpose of managing and disposing IDW, protecting the health and ensuring the safety of field and laboratory personnel, and developing corrective action alternatives (e.g., risk assessments, remediation potential) for contaminated sites. Details of these sample collection activities are provided in Section 4.2.6.

\section{A.1.9 References}

ASTM, see American Society for Testing and Materials.

Adams, S., IT Corporation. 2001. Radiological Survey Form, 14 March. Las Vegas, NV.

American Society for Testing and Materials. 2000a. Standard Test Method for Radiochemical Determination of Plutonium in Soil by Alpha Spectroscopy, C1001-2000. Philadelphia, PA.

American Society for Testing and Materials. 2000b. Standard Test Method for Strontium-90 in Water, D5811-2000. Philadelphia, PA.

American Society for Testing and Materials. 2002a. Standard Test Method for Isotopic Uranium in Water by Radiochemistry, D-3972-2002. Philadelphia, PA.

American Society for Testing and Materials. 2002b. Standard Test Method for Plutonium in Water, D-3865-02. Philadelphia, PA.

American Society for Testing and Materials. 2002c. Standard Test Method for Radiochemical Determination of Uranium Isotopes in Soil by Alpha Spectroscopy, E1000-2000.

Philadelphia, PA. 
Azhikakath, M.M., Reynolds Electrical \& Engineering Co., Inc. 1994. Memorandum to J.P. Bielawski (REECo) entitled, "History of Building WY-42, Area 6," 24 August. Las Vegas, NV.

BN, see Bechtel Nevada.

Bechtel Nevada. 1995. Nevada Test Site Performance Objective Criteria for Certification of Nonradioactive Hazardous Waste, Rev. 0, G-E11/96.01. Las Vegas, NV.

Boyd, G., Bechtel Nevada. 2002. Record of teleconference with B. Bordelois (Science Applications International Corporation) concerning materials discarded in the Building 36 septic system, 12 February. Las Vegas, NV.

Cowley, J.L., Reynolds Electrical \& Engineering Co., Inc. 1994. Memorandum to C. Neagle (REECo) entitled, "Sample Analytical Results," 3 November. Las Vegas, NV.

DOE, see U.S. Department of Energy.

DOE/NV, see U.S. Department of Energy, Nevada Operations Office.

DNA, see Defense Nuclear Agency.

DRI, see Desert Research Institute.

Dalson, D., Bechtel Nevada (Retired). 2002a. Record of teleconference with B. Bordelois (Science Applications International Corporation) concerning operations and naming of Building 36, 13 February. Las Vegas, NV.

Dalson, D., Bechtel Nevada (Retired). 2002b. Record of teleconference with B. Bordelois (Science Applications International Corporation) concerning operations and naming of Building 45, 13 February. Las Vegas, NV.

Defense Nuclear Agency. 1982. Shorts Sugar and Uncle - The Final Tests of the Buster-Jangle Series 19 November - 29 November 1951, 23 June; DNA 6025F. Washington DC.

Desert Research Institute. 1993. Data Report: ER-6-1 Hydrologic Testing and Geochemical Sampling Results. Prepared by D.R. Gillespie. Las Vegas, NV: Water Resources Center.

EPA, see U.S. Environmental Protection Agency.

Emer, D., Bechtel Nevada. 2001. Personal communication to R. Jackson (Bechtel Nevada) entitled, "CAU 140 and 516 ISOCS Gamma Spectroscopy Results," 10 October. Las Vegas, NV. 
Holmes \& Narver, Inc. 1976. Engineering drawing JS-003-3C-45-C2.1 entitled, "Nevada Test Site Area 3 LASL Building 3C-45 Rack and Compensator Fac. Addition Surface Treatment," 19 January. Mercury, NV: Archives and Records Center.

Holmes \& Narver, Inc. 1978. Engineering drawing JS-003-3C-45-C1.4, "Nevada Test Site Area LASL Building 3C-45 Rack and Compensator Facility Addition Plot Plan \& Details," 10 November. Mercury, NV: Archives and Records Center.

Holmes \& Narver, Inc. 1985. Engineering drawing JS-003-3C-36-C1.1, "Nevada Test Site Area 3 - Los Alamos Building No. 3C-36 WX-9 Office Complex Plot \& Grading Plan Details," 23 January. Mercury, NV: Archives and Records Center.

Kodak. 1998a. Material Safety Data Sheets for Product Name: Kodak Developer D-76, 200000233/F/USA, February.

Kodak. 1998b. Material Safety Data Sheets for Product Name: Kodak Indicator Stop Bath, 200001041/F/USA, February.

IT, see IT Corporation.

IT Corporation. 1998. Radiological Survey, April. Las Vegas, NV.

IT Corporation. 2001. Digital Photographs for CAU 516, CAS 22-19-04. Las Vegas, NV.

IT Corporation. 2002. Radiological Soil Survey of Selected Sites for Preliminary Assessments Geophysical Sites Fall 2001, 19 January. Las Vegas, NV.

Latham, A.R., Reynolds Electrical \& Engineering Co., Inc. 1995. Memorandum to S.C. Okosisi (Reynolds Electrical \& Engineering Co., Inc.) entitled, "Sample Radioanalytical Results," 7 December. Las Vegas, NV.

Laub, M., Bechtel Nevada. 2001. Record of teleconference with M. Swearingen (IT Corporation) concerning Building 660, 10 April. Las Vegas, NV.

Madsen, D., Bechtel Nevada. 2001. Record of teleconference with M. Swearingen (IT Corporation) concerning Building 660, 10 April. Las Vegas, NV.

Marshall, D., Bechtel Nevada. 2002. Record of teleconference with B. Bordelois (Science Applications International Corporation) concerning activities associated with Building 36, 7 February. Las Vegas, NV.

McArthur, R.D., and R.L. Miller, Jr. 1989. Off-Site Radiation Exposure Review Project, Phase II Soil Program, DOE/NV/10384-23. Las Vegas, NV: Desert Research Institute. 
Moore, J., Science Applications International Corporation. 1999. Memorandum to M. Todd (Science Applications International Corporation), "Background Concentrations for NTS and TTR Soil Samples," 3 February. Las Vegas, NV.

NAC, see Nevada Administrative Code.

NBMG, see Nevada Bureau of Mines and Geology.

NNSA/NV, see U.S. Department of Energy, National Nuclear Security Administration Nevada Operations Office.

Nevada Administrative Code. 2002. NAC 445A.2272, "Contamination of Soil: Establishment of Action Levels." Carson City, NV.

Nevada Bureau of Mines and Geology. 1998. Mineral and Energy Resource Assessment of the Nellis Air Force Range, Open-File Report 98-1. Reno, NV.

Phellan, M., Bechtel Nevada. 2002. Record of teleconference with L. Linden (Science Applications International Corporation) concerning chemicals used in photoprocessing, 9 December. Las Vegas, NV.

People for Pugent Sound. 2001. "What is Sewage.” As accessed at http://www.pugetsound.org/ sewage/report/sewage.html on 9 October.

REECo, see Reynolds Electrical \& Engineering Co., Inc.

RSL, see Remote Sensing Laboratory.

Remote Sensing Laboratory. 1966. Aerial photographs of CAU 516, CAS 22-19-04. Nellis Air Force Base, NV: Photo Archives Library.

Remote Sensing Laboratory. 1971. Aerial Photograph of Well 3 Yard. Nellis Air Force Base, NV: Photo Archives Library.

Reynolds Electrical \& Engineering Co., Inc. 1964a. Engineering drawing RE-791 entitled, "U.S. Public Health Service Facilities for Milk Cows Plot Plan," 1 December. Las Vegas, NV.

Reynolds Electrical \& Engineering Co., Inc. 1964b. Engineering drawing RE-788 entitled, "U.S. Public Health Service Facilities for Milk Cows Mechanical Plan," 7 February. Las Vegas, NV.

Reynolds Electrical \& Engineering Co., Inc. 1994. Individual Investigation TKDE-001RW-06, 7 December. Las Vegas, NV. 
Reynolds Electrical \& Engineering Co., Inc. 1995. Area 3 Base Camp Closure Demolition and Environmental Total Estimated Cost, August. Las Vegas, NV.

SAIC, see Science Applications International Corporation.

Science Applications International Corporation. 2001. Surface Geophysical Survey Report Preliminary Assessments Sites Nevada Test Site, December. Harrisburg, PA.

Sunspot Productions. 2002. Photographic Chemicals. As accessed at Sunspotphoto.com on 5 June.

Sygitowicz, L.S., Reynolds Electrical \& Engineering Co., Inc. 1995. Letter to D.R. Elle (U.S. Department of Energy, Nevada Operations Office) entitled, "Closure Notification for Holding Tank Servicing Building WY-42, Well 3 Yard Calibration Laboratory, Area 6," 20 December. Las Vegas, NV.

USGS, see U.S. Geological Survey.

Urbon, A., Bechtel Nevada. 2003. Teleconference with L. Linden (Science Applications International Corporation) regarding the analytical results (attached to teleconference form) for samples collected from the underground storage tank at CAS 06-02-04 in CAU 330, 1 April. Las Vegas, NV.

U.S. Department of Energy. 1997. Procedures Manual of the Environmental Measurements Laboratory Procedures Manual, HASL-300, 28th Ed., Vol. I. New York, NY.

U.S. Department of Energy, National Nuclear Security Administration Nevada Operations Office. 2002. Industrial Sites Quality Assurance Project Plan, Nevada Test Site, Nevada, DOE/NV--371--REV. 3. Las Vegas, NV.

U.S. Department of Energy, Nevada Operations Office. 1990. NTS Drilling and Mining Summary. Prepared by Raytheon Services Nevada. Las Vegas, NV.

U.S. Department of Energy, Nevada Operations Office. 1996. U.S. Department of Energy Nevada Operations Office Environmental Data Report for the Nevada Test Site -- 1994. Prepared by S.C. Black and Y.E. Townsend of Bechtel Nevada. Las Vegas, NV.

U.S. Department of Energy, Nevada Operations Office. 1998. Nevada Test Site Resource Management Plan, DOE/NV--518. Las Vegas, NV.

US Ecology and Atlan-Tech, Inc. 1991. Environmental Monitoring Report for the Proposed Ward Valley, California, Low-Level Radioactive Waste (LLRW) Facility, Volumes 1 and 2. Rosewell, GA.

U.S. Environmental Protection Agency. 1980. Prescribed Procedures for Measurements of Radioactivity in Drinking Water, EPA-600/4-80-032. Washington, DC. 
U.S. Environmental Protection Agency. 1984. Animal Investigation Program for the Nevada Test Site: 1957 - 1981, EPA 600/6-84, January. Las Vegas, NV.

U.S. Environmental Protection Agency. 1996. Test Methods for Evaluating Solid Waste, Physical/Chemical Methods, SW-846, CD-ROM PB97-50192GEI which contains updates for 1986, 1992, 1994, and 1996. Washington, DC.

U.S. Environmental Protection Agency. 2002. Memorandum from S. J. Smucker to PRG Table Mailing List regarding Region 9 Preliminary Remediation Goals (PRGs), 1 October.

San Francisco, CA.

U.S. Geological Survey. 1975. Hydrogeologic and Hydrochemical Framework, South-Central Great Basin, Nevada-California, with Special Reference to the Nevada Test Site, USGS Professional Paper 712-C. Prepared by I.J. Winograd and W. Thordarson. Washington, DC.

Wuellner, J.W., Reynolds Electrical \& Engineering Co., Inc. 1994. Memorandum to J.R. Bielawski (Reynolds Electrical and Engineering Co., Inc.) entitled, "Historical Information, Area 3 Waste Mud Impoundment," 2 May. Las Vegas, NV. 
CAU 516 Closure Report Section: Appendix A

Revision: 0

Date: April 2007

THIS PAGE INTENTIONALLY LEFT BLANK 


\section{APPENDIX B}

\section{ANALYTICAL RESULTS}


THIS PAGE INTENTIONALLY LEFT BLANK 


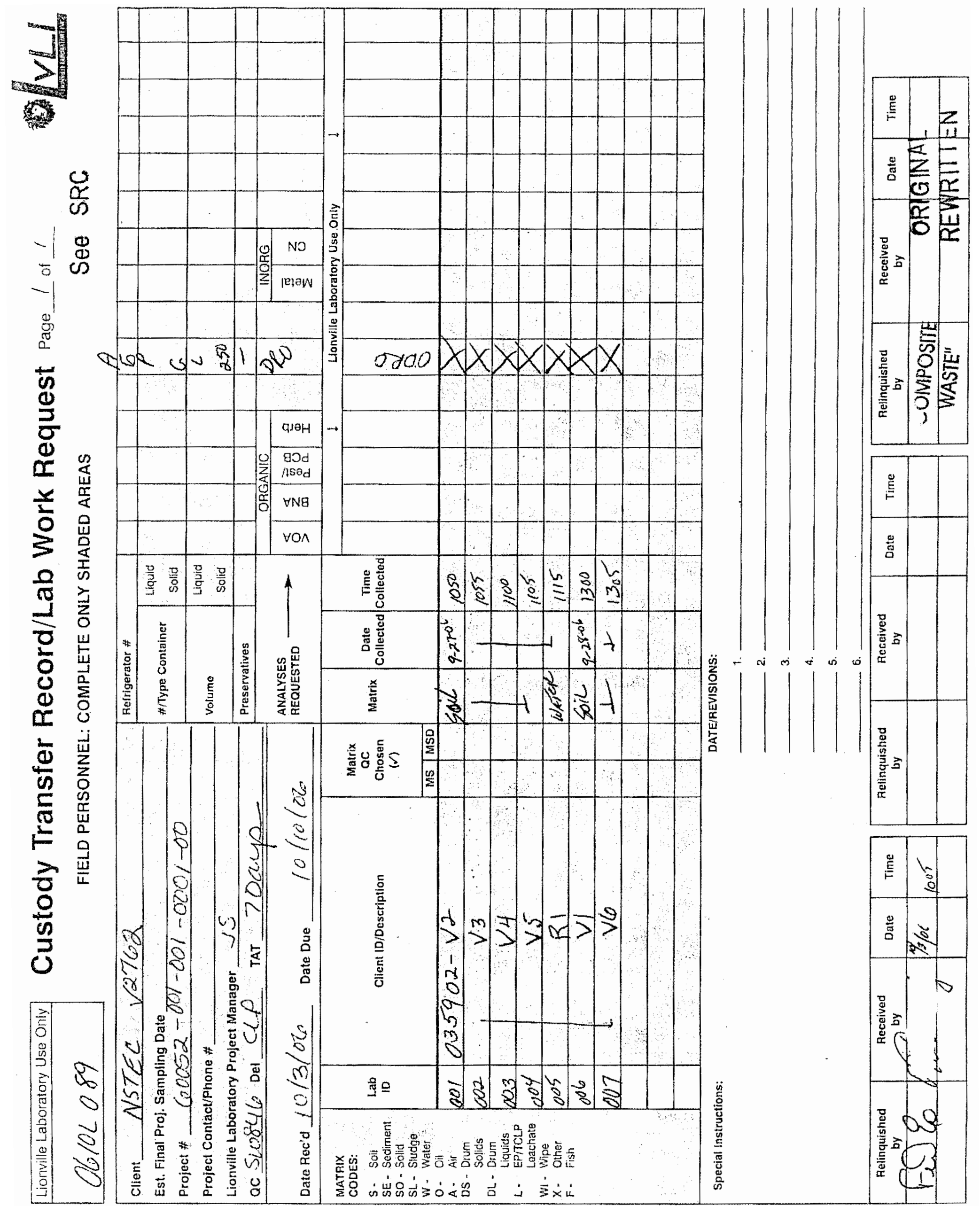




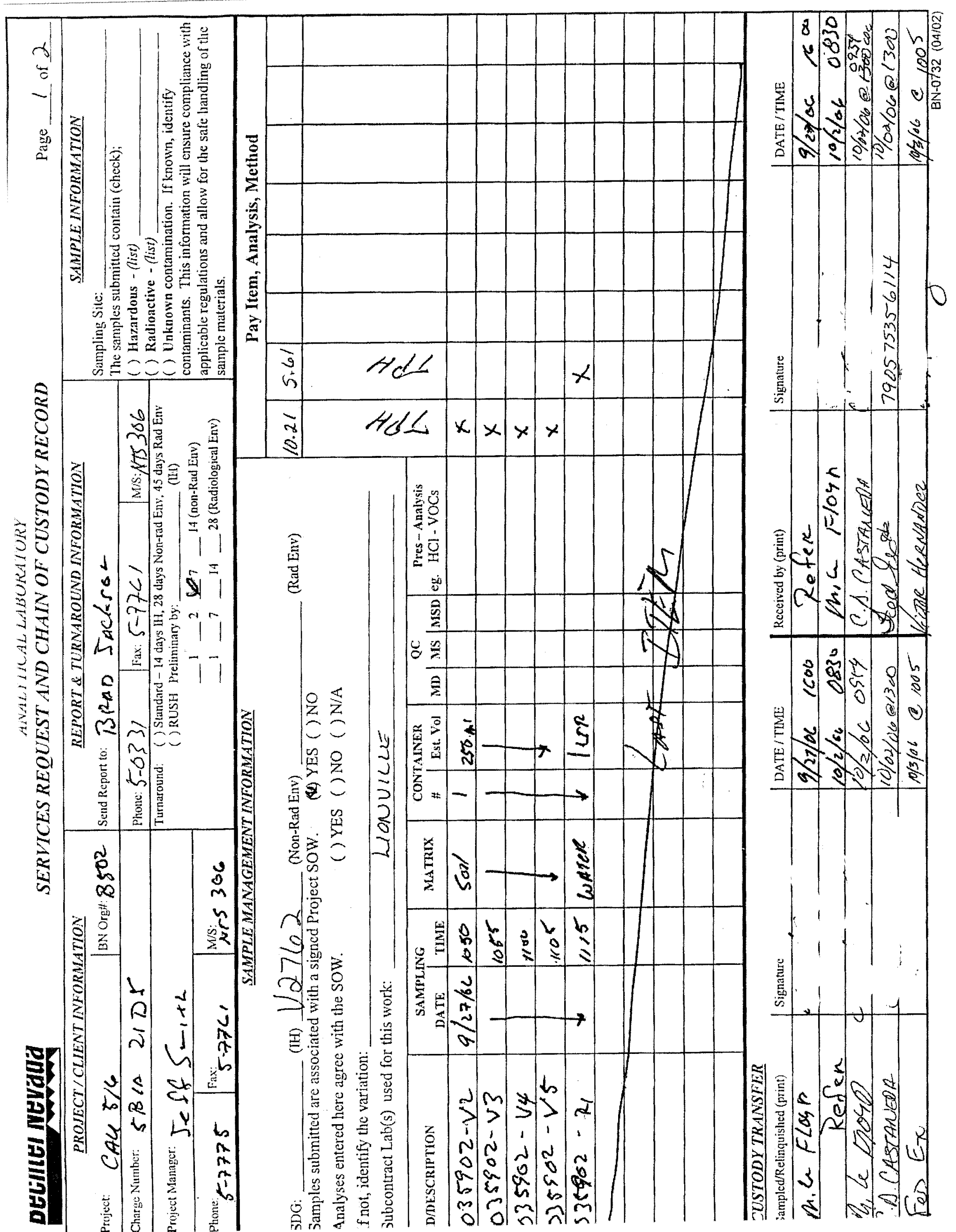




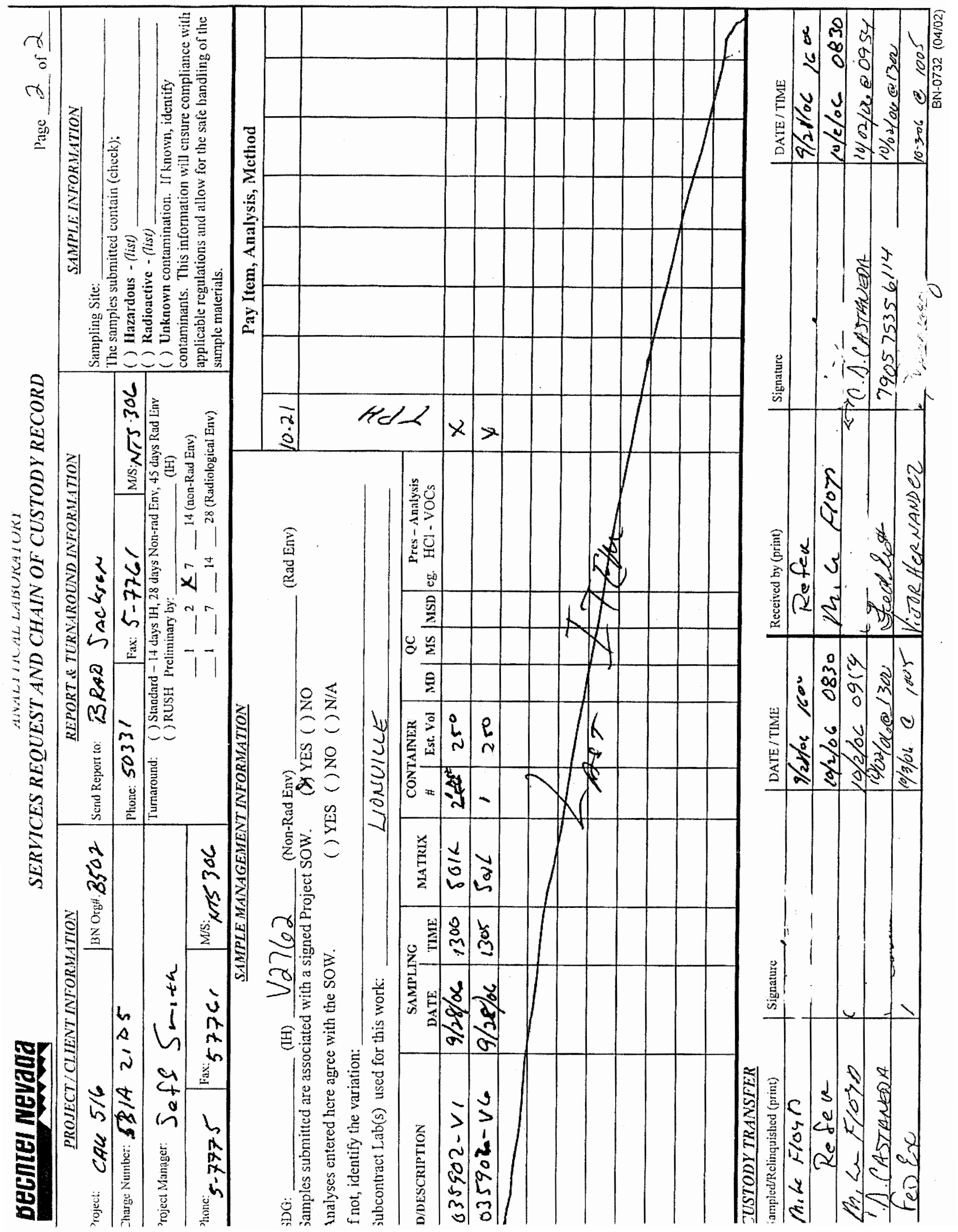




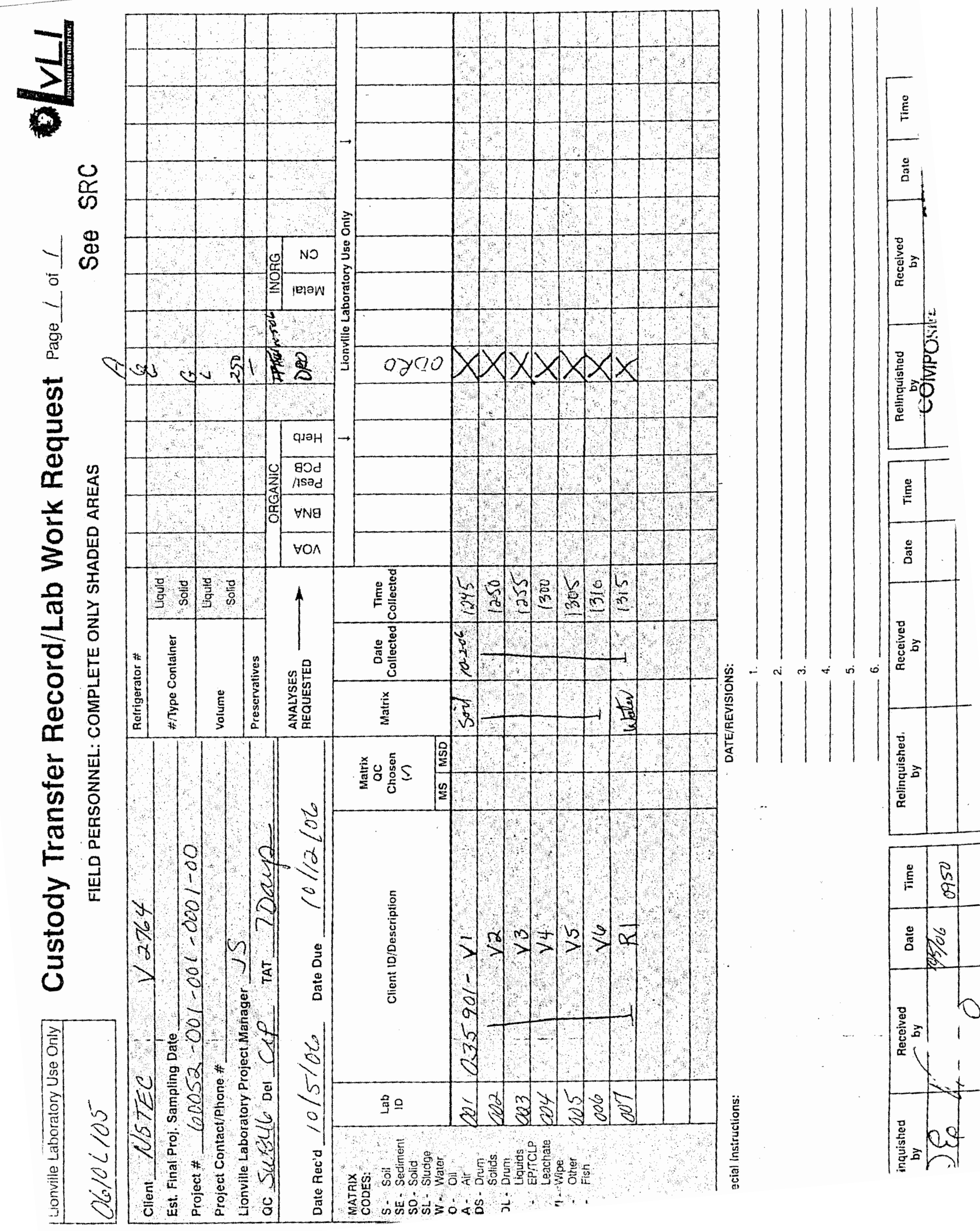




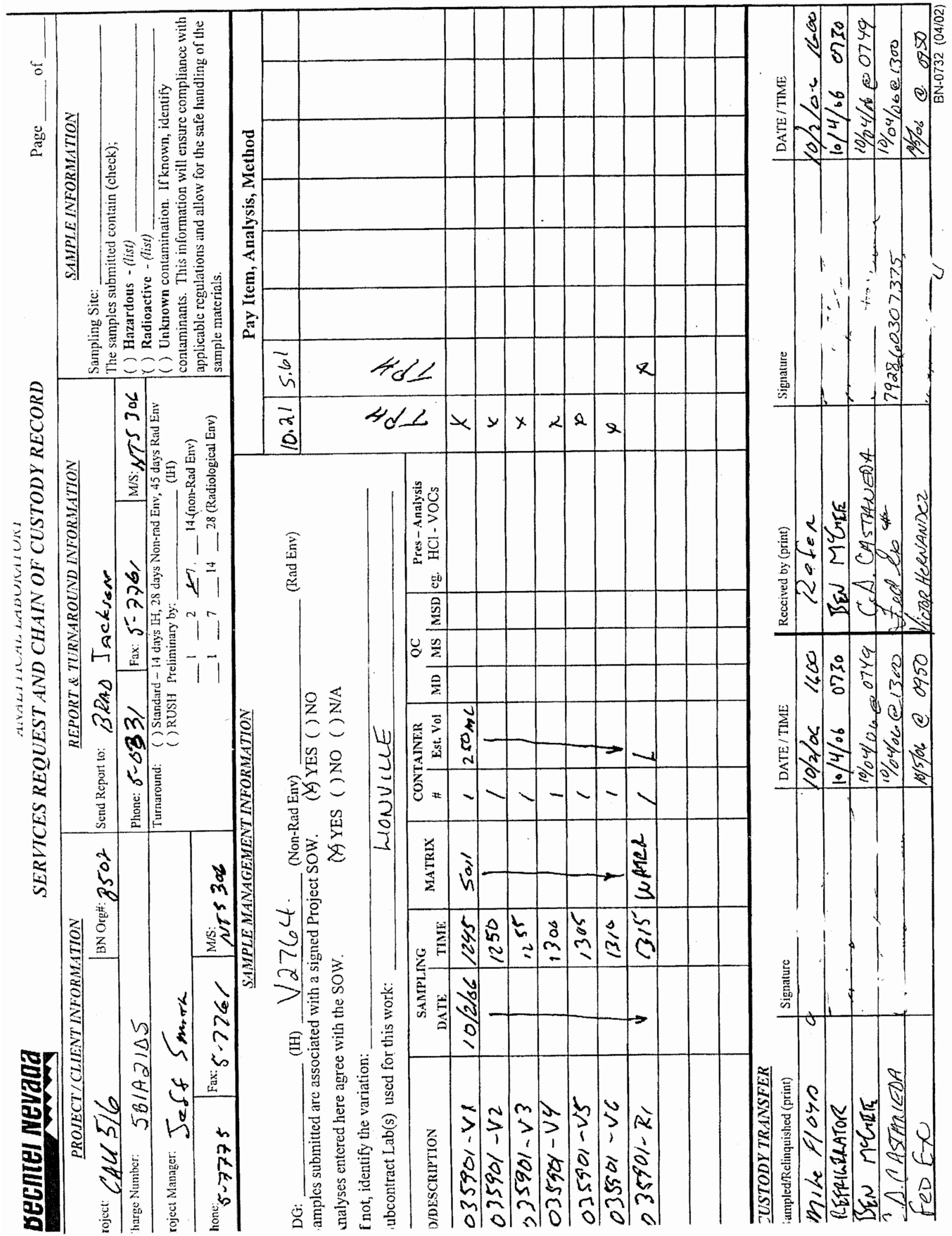




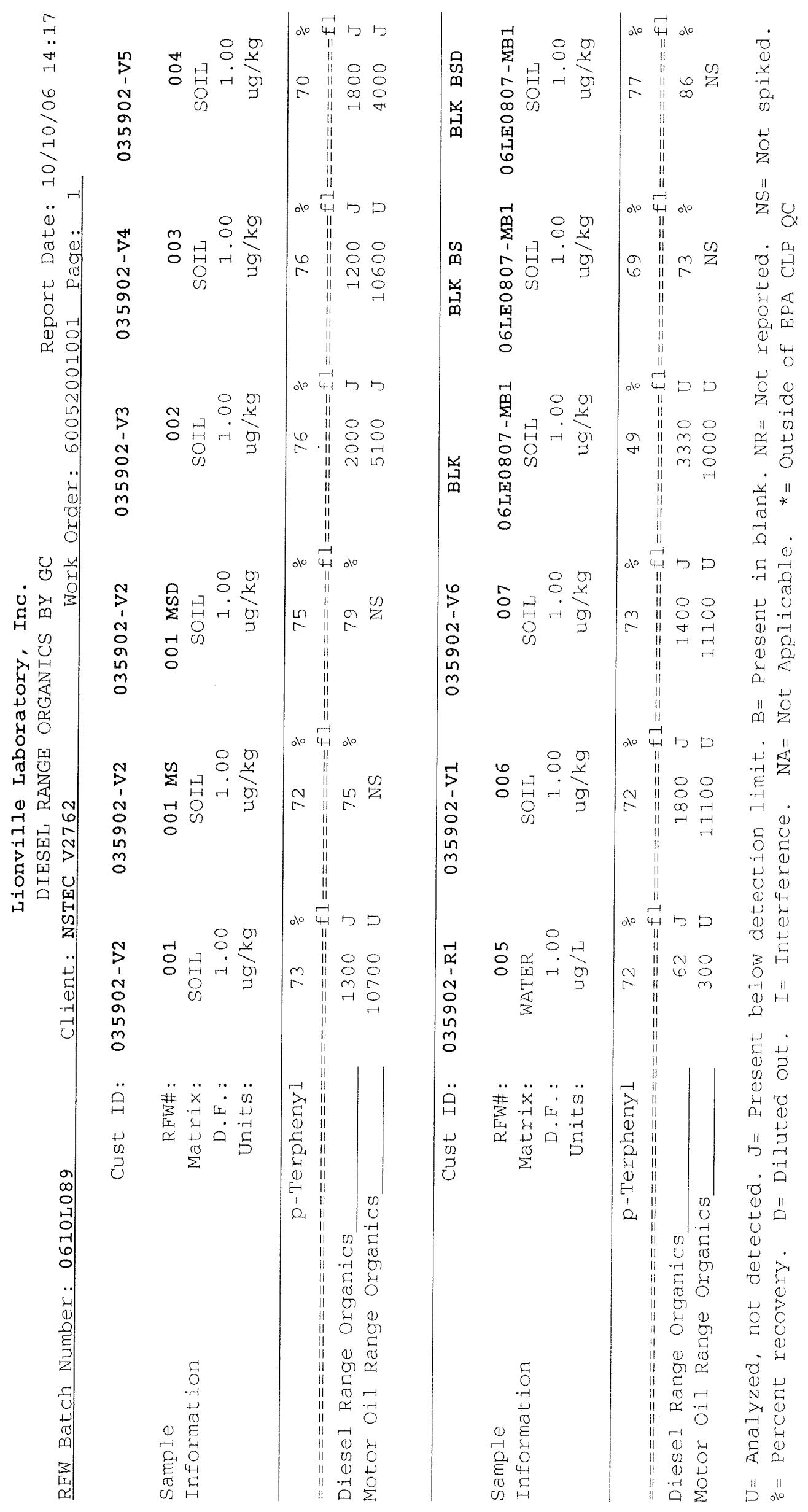




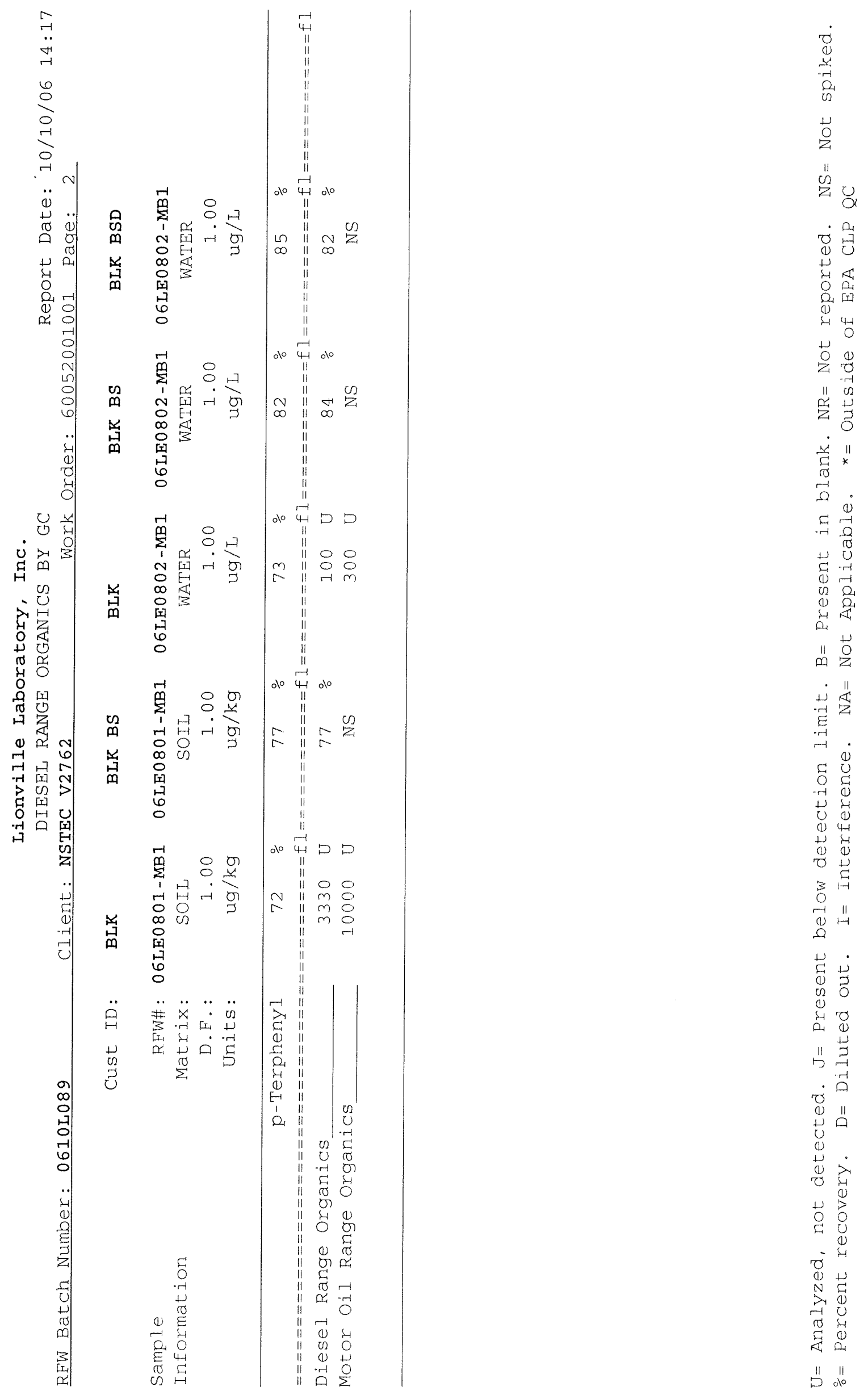




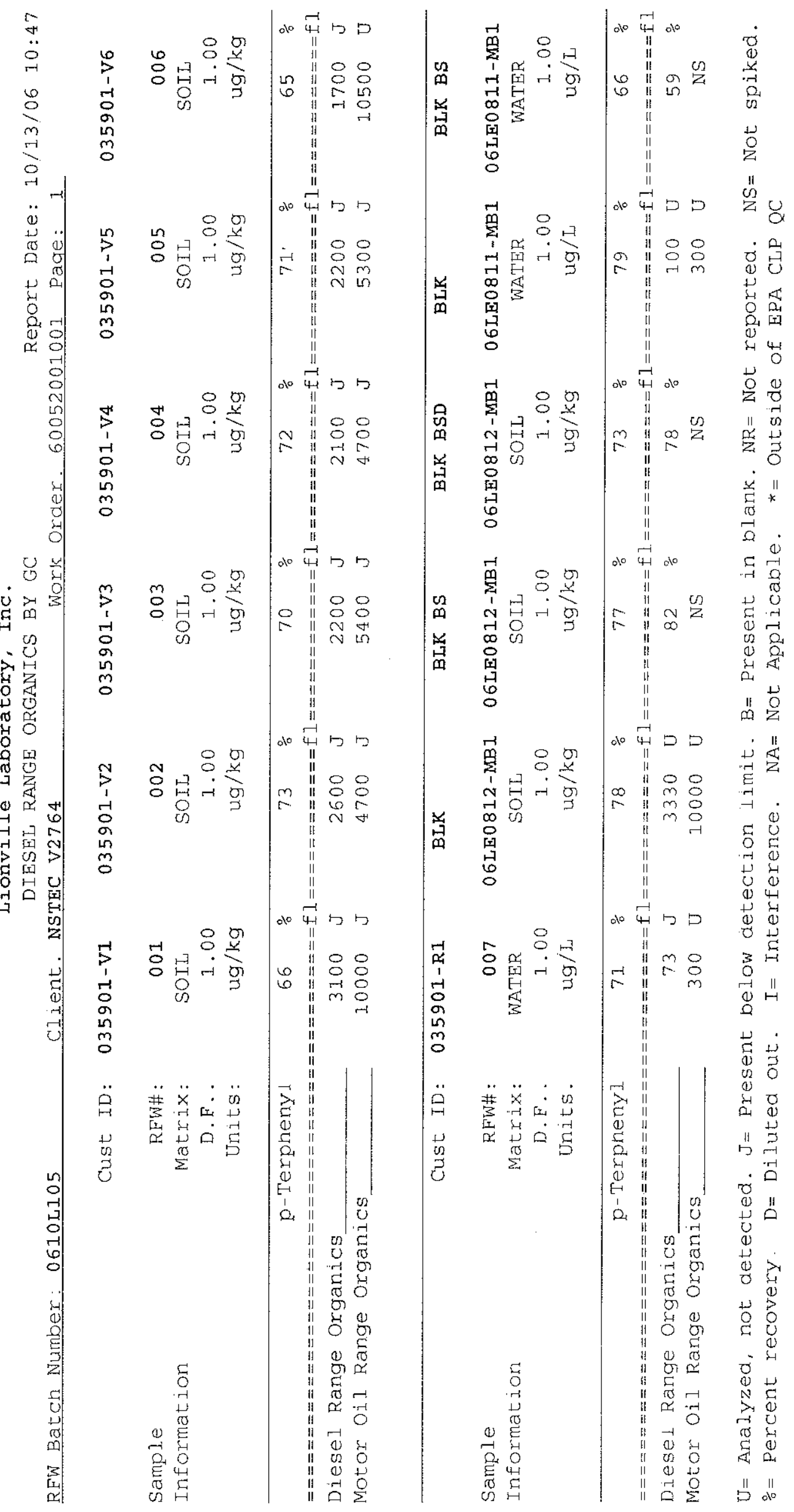




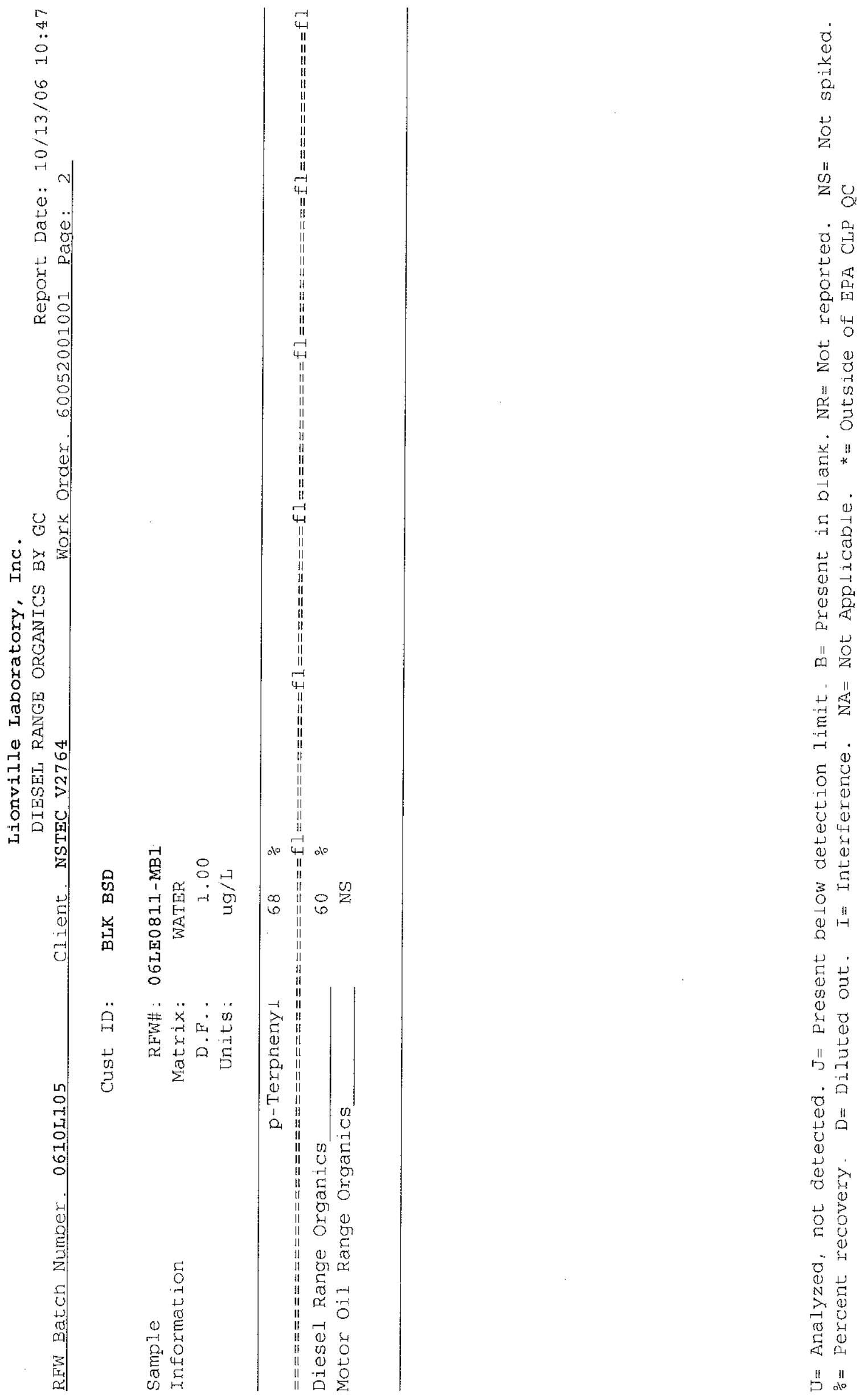


Southwest Analytical, Inc.

Date: 04-Aug-06

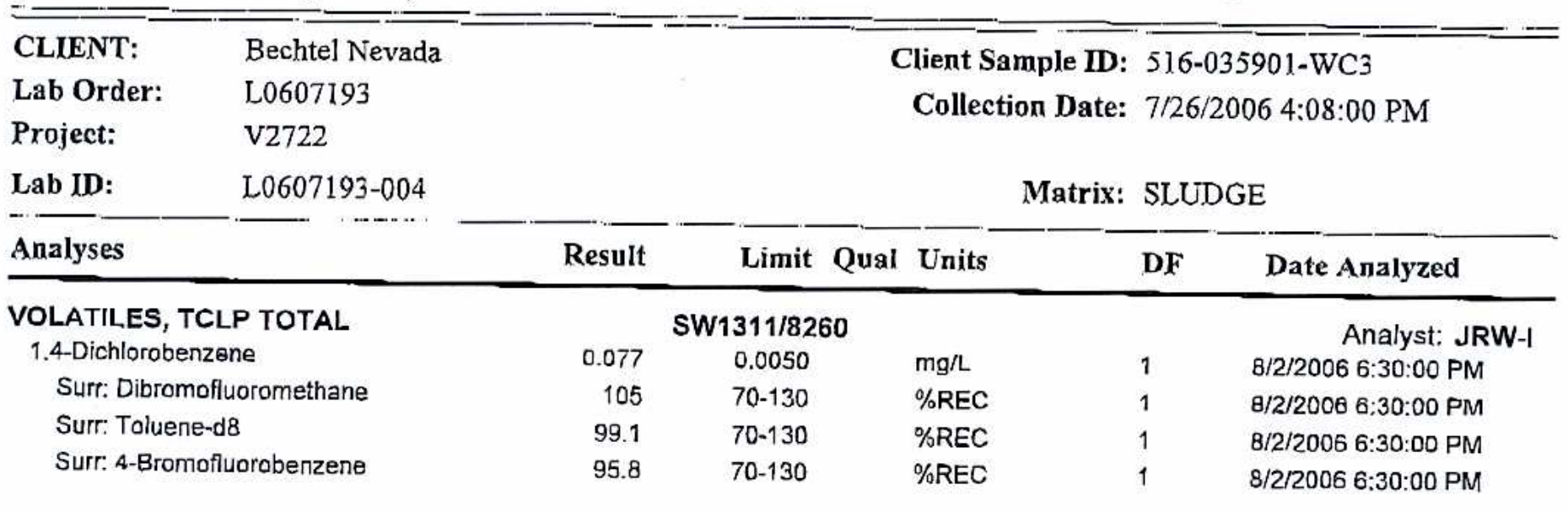


Southwest Analytical, Inc.

Date: 04-Aug-06

\section{CLIENT: Bechtel Nevada}

Lab Order: L L607193

Project: V2722

Lab ID: L0607193-003

-. -....

Analyses

VOLATILES, TCLP TOTAL

1,4-Dichlorobenzene

Surr: Dibromofluoromethane

Surr: Toluene-d8

Surr: 4-Bromofluorobenzene

$+-1$

Client Sample ID: 516-035901-WC2

Collection Date: 7/26/2006 4:12:00 PM

Matrix: WATER

\begin{tabular}{rcccc}
\hline Result & Limit Qual Units & DF & Date Analyzed \\
ND & SW1311/8260 & & & Analyst: JRW-I \\
104 & 0.0050 & mg/L & 1 & $7 / 28 / 20064: 49: 00 \mathrm{PM}$ \\
97.8 & $70-130$ & \%REC & 1 & $7 / 28 / 20064: 49: 00 \mathrm{PM}$ \\
97.1 & $70-130$ & \%REC & 1 & $7 / 28 / 20064: 49: 00 \mathrm{PM}$ \\
& & \%REC & 1 & $7 / 28 / 20064: 49: 00 \mathrm{PM}$
\end{tabular}


Southwest Analytical, Inc.

Date: 04-Aug-06

\begin{tabular}{|c|c|c|c|c|c|c|c|c|}
\hline $\begin{array}{l}\text { CLIENT: } \\
\text { Lab Order: }\end{array}$ & $\begin{array}{l}\text { Bechtel Nevada } \\
\text { L0607193 }\end{array}$ & & \multicolumn{6}{|c|}{ Client Sample ID: 516-035901-WC1 } \\
\hline Project: & V2722 & & \multicolumn{4}{|c|}{ Collection Date: } & \multicolumn{2}{|c|}{ 7/26/2006 3:51:00 PM } \\
\hline Lab ID: & L06071.93-002 & & \multicolumn{4}{|r|}{ Matrix: } & \multicolumn{2}{|c|}{ WATER } \\
\hline \multicolumn{2}{|l|}{ Analyses } & Result & Limit & Qual & Units & & DF & Date Analyzed \\
\hline \multicolumn{2}{|c|}{$\begin{array}{l}\text { VOLATILES, TCLP TOTAL } \\
\text { 1,4-Dichlorobenzene }\end{array}$} & \multicolumn{4}{|c|}{ SW1311/8260 } & & & $\begin{array}{l}\text { Analyst: JRW-I } \\
\text { 7/28/2006 } 4 \cdot 11.00 \text { PM }\end{array}$ \\
\hline \multicolumn{2}{|c|}{ Surr: Dibromofluoromethane } & 103 & $\begin{array}{l}0.0050 \\
70-130\end{array}$ & & $\begin{array}{l}\mathrm{mg} / \mathrm{L} \\
\% R E C\end{array}$ & & $\begin{array}{l}1 \\
1\end{array}$ & $\begin{array}{l}\text { 7/28/2006 4:11:00 PM } \\
\text { 7/28/2006 4:11:00 PM }\end{array}$ \\
\hline \multirow{2}{*}{\multicolumn{2}{|c|}{$\begin{array}{l}\text { Surr: Toluene-dB } \\
\text { Surr: 4-Bromofluorobenzene }\end{array}$}} & 98.1 & $70-130$ & & \%REC & & 1 & 7/28/2006 4:11:00 PM \\
\hline & uorobenzene & 94.6 & $70-130$ & & $\%$ REC & & 1 & 7/28/2006 4:11:00 PM \\
\hline
\end{tabular}


Southwest Analytical, Inc.

Date: 04-Aug-06

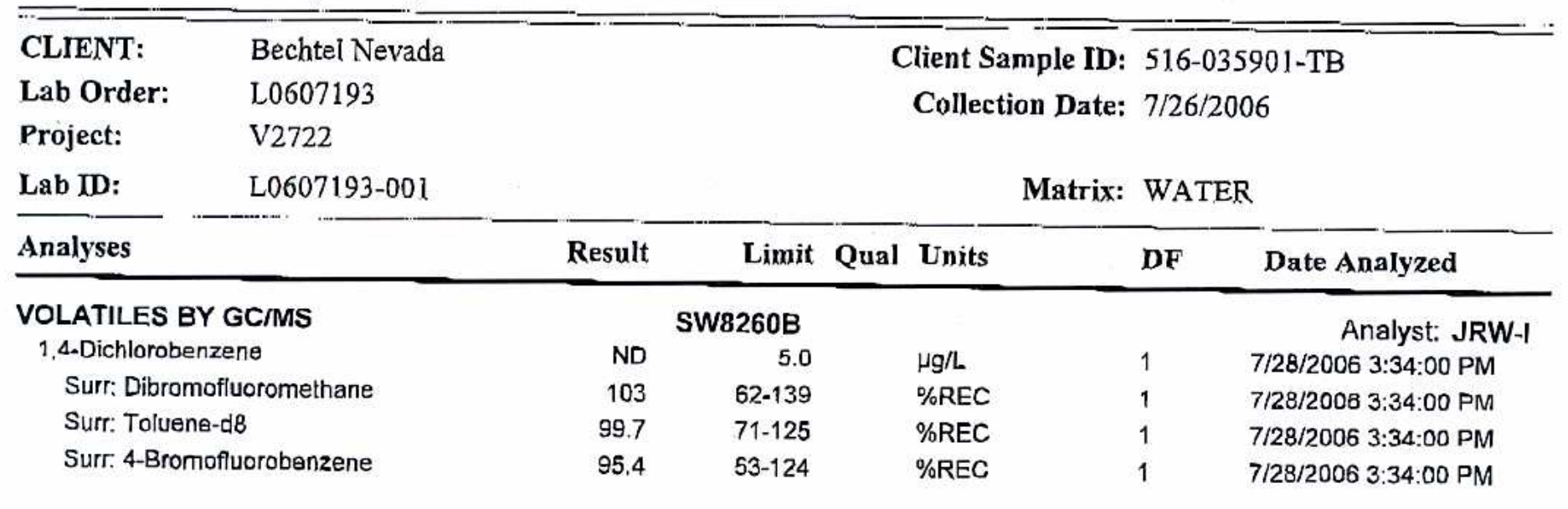



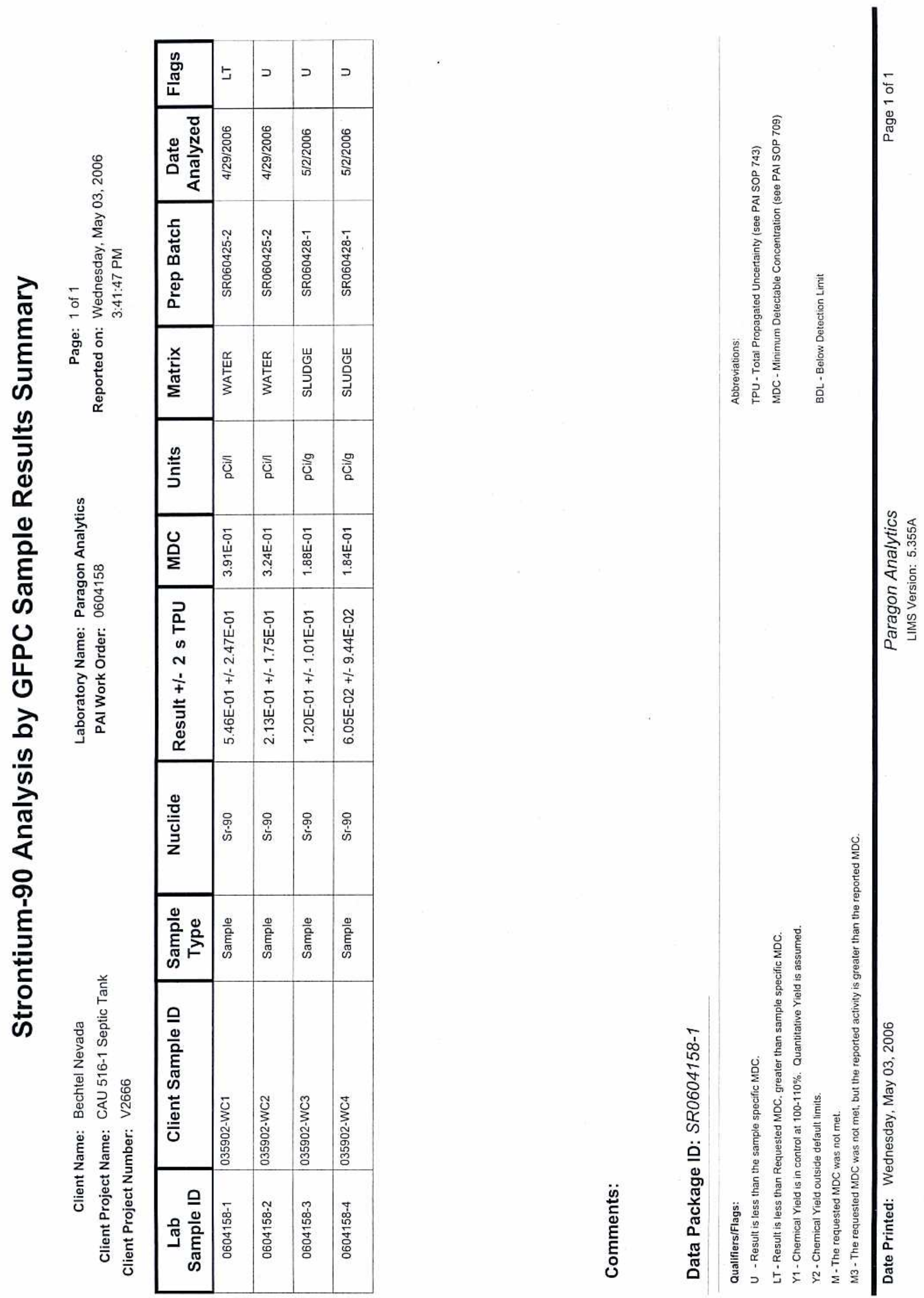


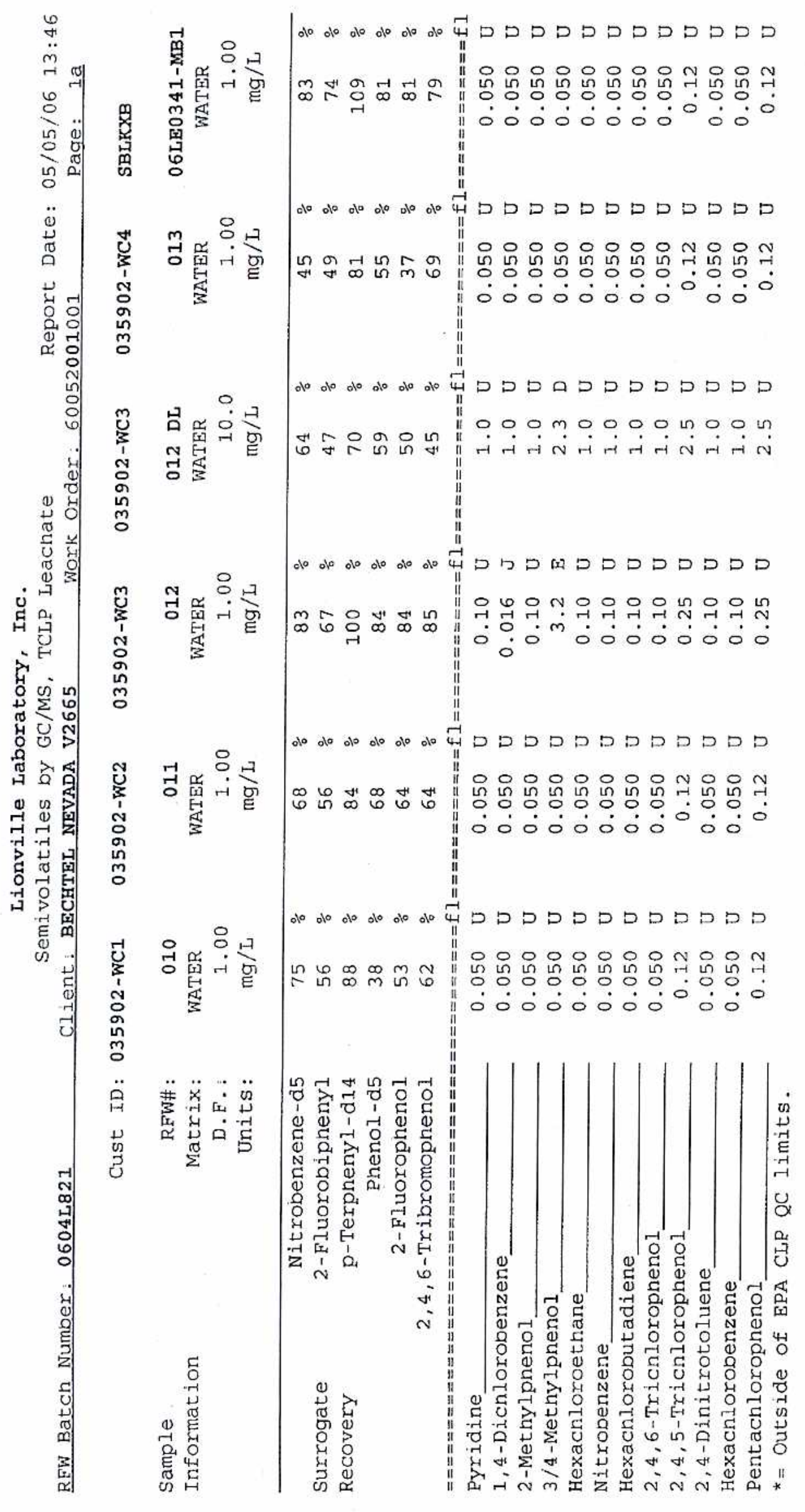




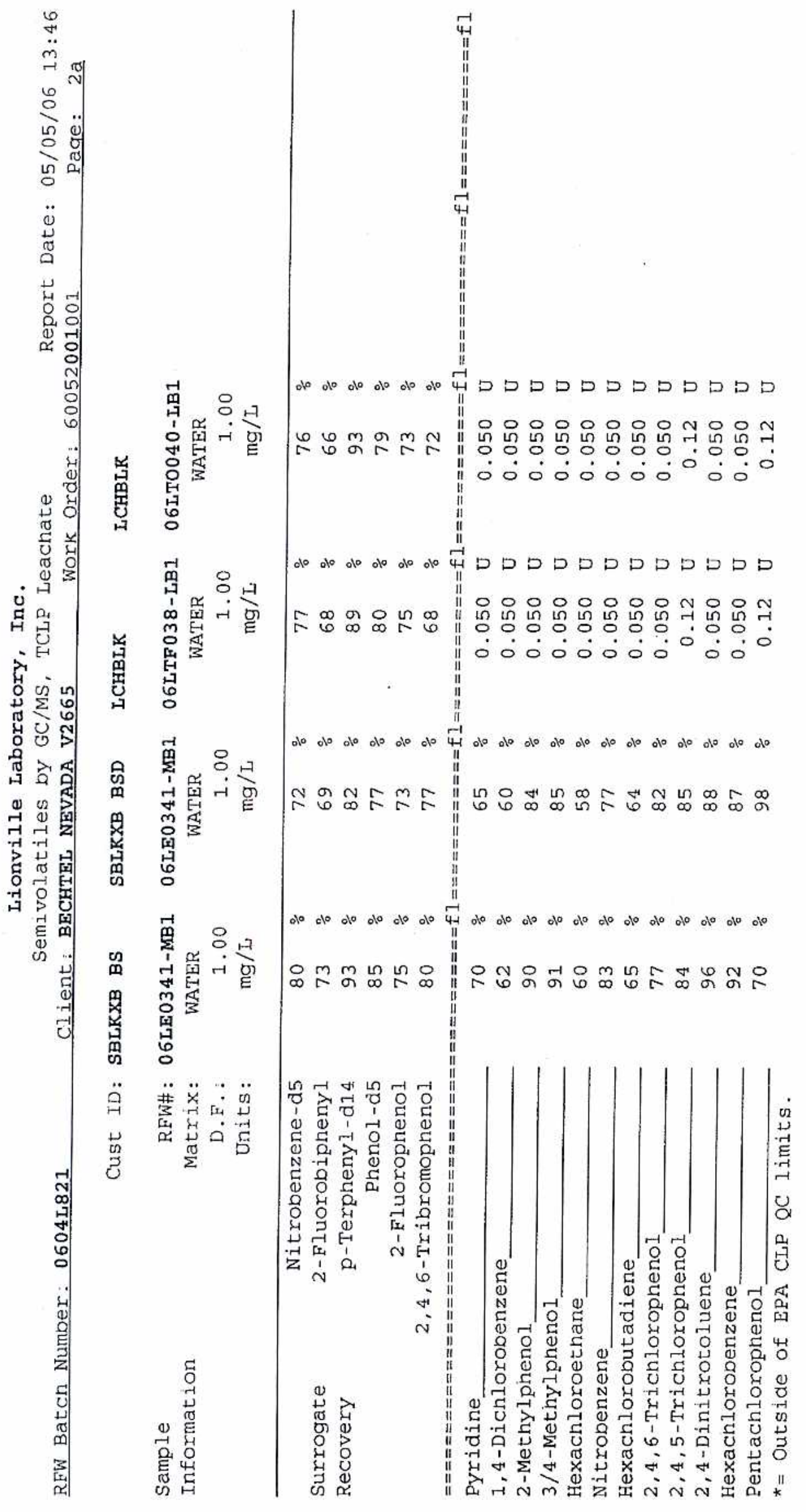


Southwest Analytical, Inc.

Date: $04-A u g-06$

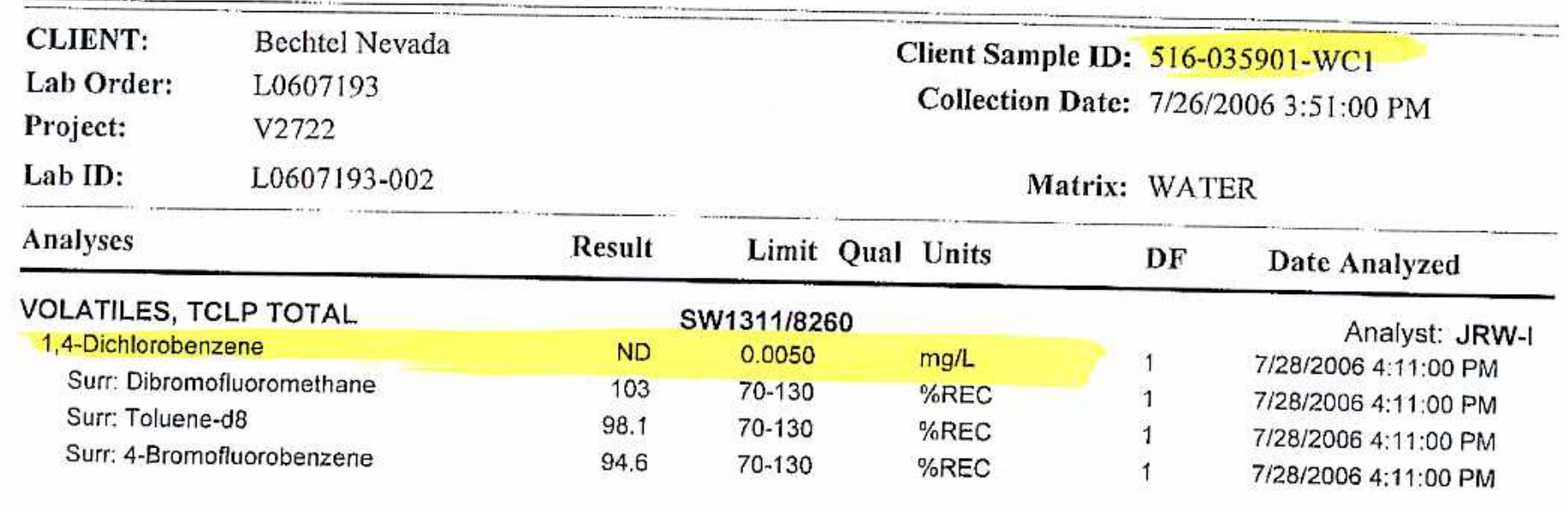


Southwest Analytical, Inc.

Date: 04-Aug-06

\begin{tabular}{|c|c|c|c|c|c|c|c|}
\hline CLIENT: & Bechtel Nevada & & \multirow{2}{*}{\multicolumn{3}{|c|}{$\begin{array}{r}\text { Client Sample ID: } \\
\text { Collection Date: }\end{array}$}} & \multicolumn{2}{|c|}{$\begin{array}{l}516-035901-W C 2 \\
7 / 26 / 20064: 12: 00 \text { PM }\end{array}$} \\
\hline Project: & V2722 & & & & & & \\
\hline Lab ID: & L.0607193-003 & & \multicolumn{3}{|r|}{ Matrix: } & \multicolumn{2}{|c|}{ WATER } \\
\hline \multicolumn{2}{|l|}{ Analyses } & Result & Limit Qual & Units & & DF & Date Analyzed \\
\hline \multirow{2}{*}{\multicolumn{2}{|c|}{$\begin{array}{l}\text { VOLATILES, TCLP TOTAL } \\
\text { 1,4-Dichlorobenzene }\end{array}$}} & \multicolumn{3}{|c|}{$\mathrm{SW} 1311 / 8260$} & \multicolumn{3}{|r|}{ Analyst: JRW-I } \\
\hline & & ND & 0.0050 & $\mathrm{mg} / \mathrm{L}$ & & 1 & 7/28/2006 4:49:00 PM \\
\hline \multicolumn{2}{|c|}{ Surr: Dibromofluoromethane } & 104 & $70-130$ & \%REC & & 1 & 7/28/2006 4:49:00 PM \\
\hline \multirow{2}{*}{\multicolumn{2}{|c|}{$\begin{array}{l}\text { Surr: Toluene-d8 } \\
\text { Surr: 4-Bromofluorobenzene }\end{array}$}} & 97.8 & $70-130$ & $\%$ REC & & 1 & 7/28/2006 4:49:00 PM \\
\hline & Iuorobenzene & 97.1 & $70-130$ & $\%$ REC & & 1 & 7/28/2006 4:49:00 PM \\
\hline
\end{tabular}


Southwest Analytical, Inc.

Date: 04-Aug-06

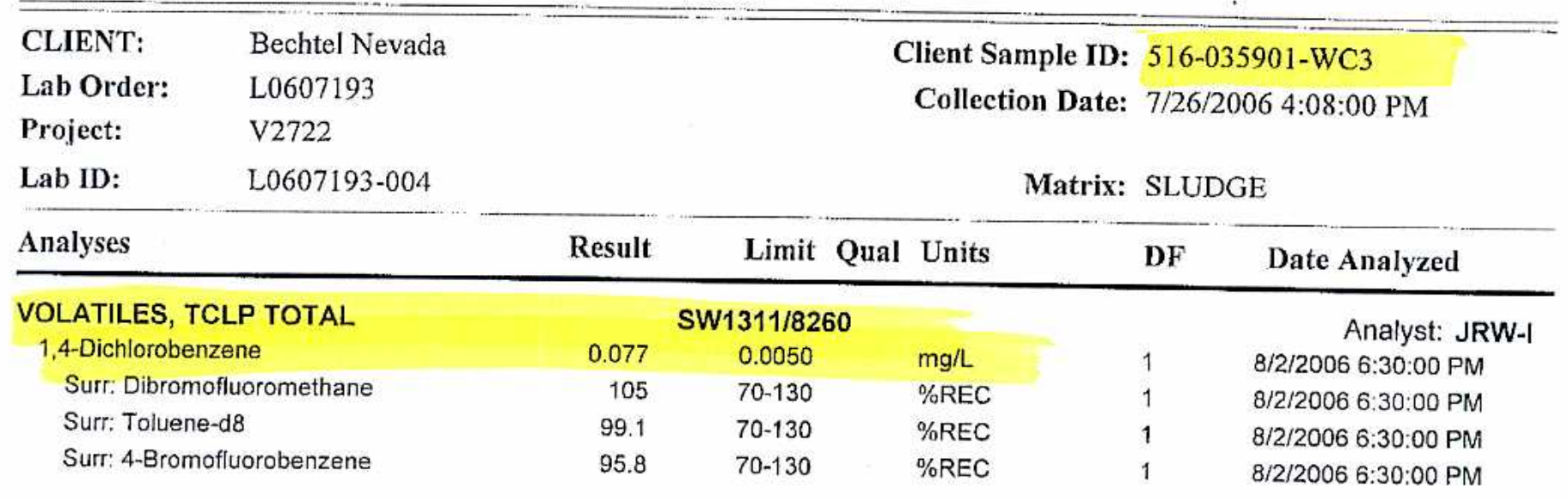


Southwest Analytical, Inc.

Date: 04-Aug-06

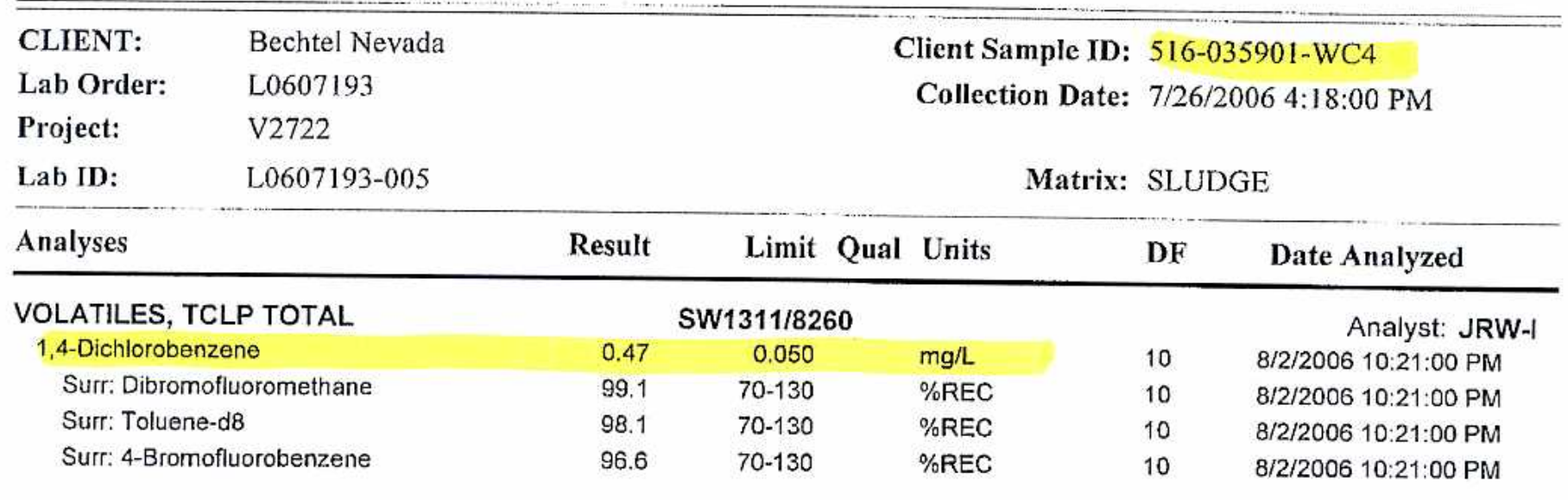




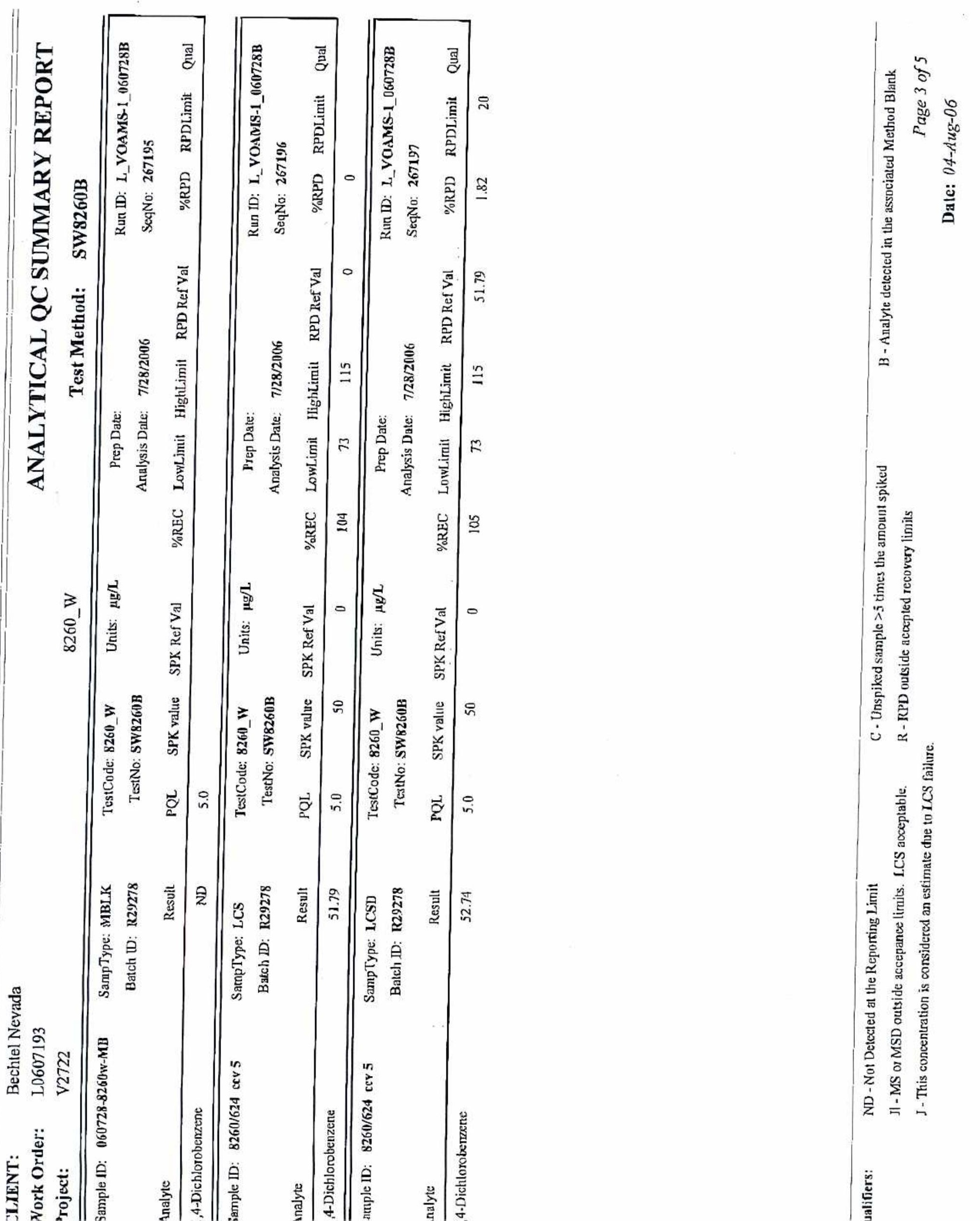




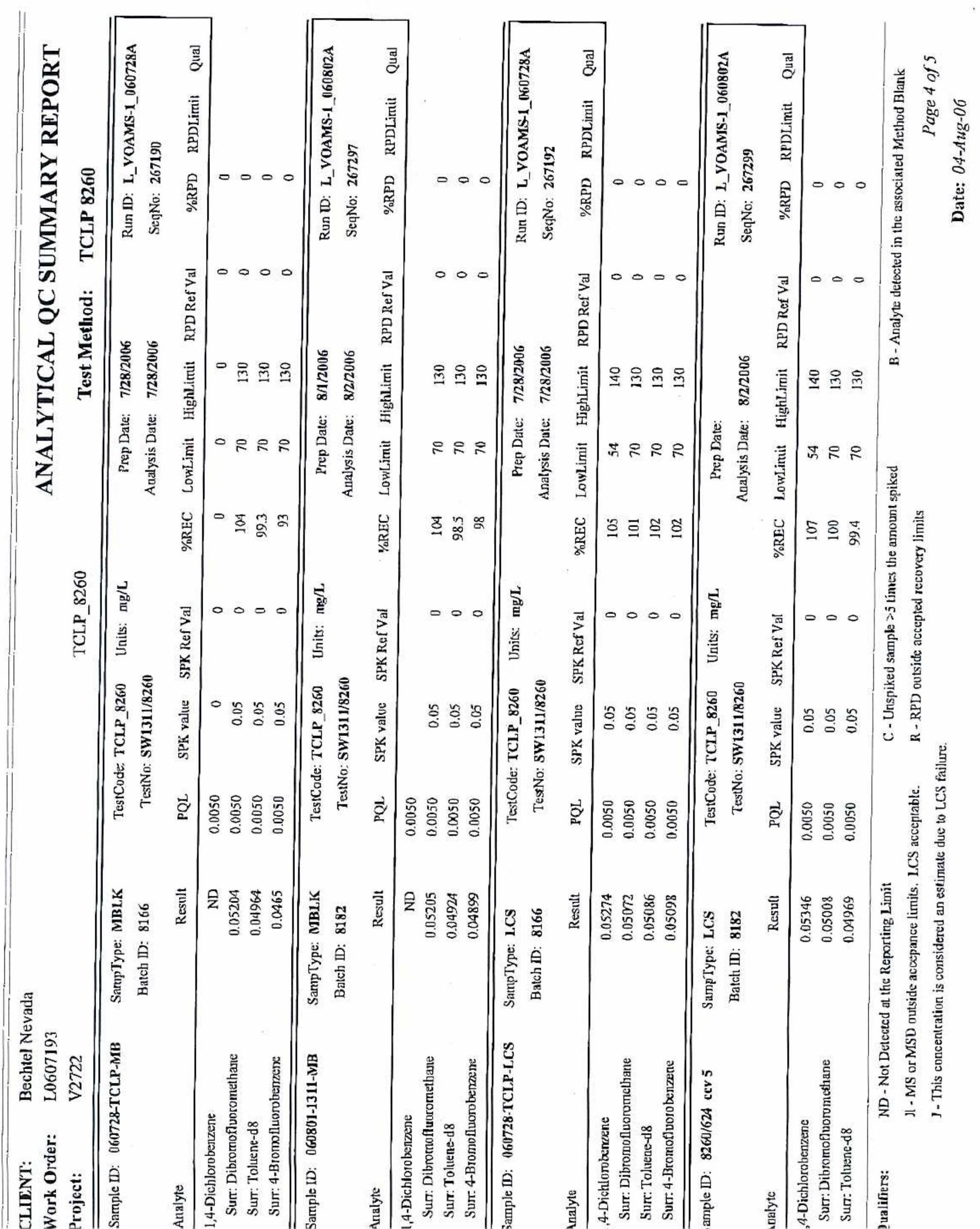




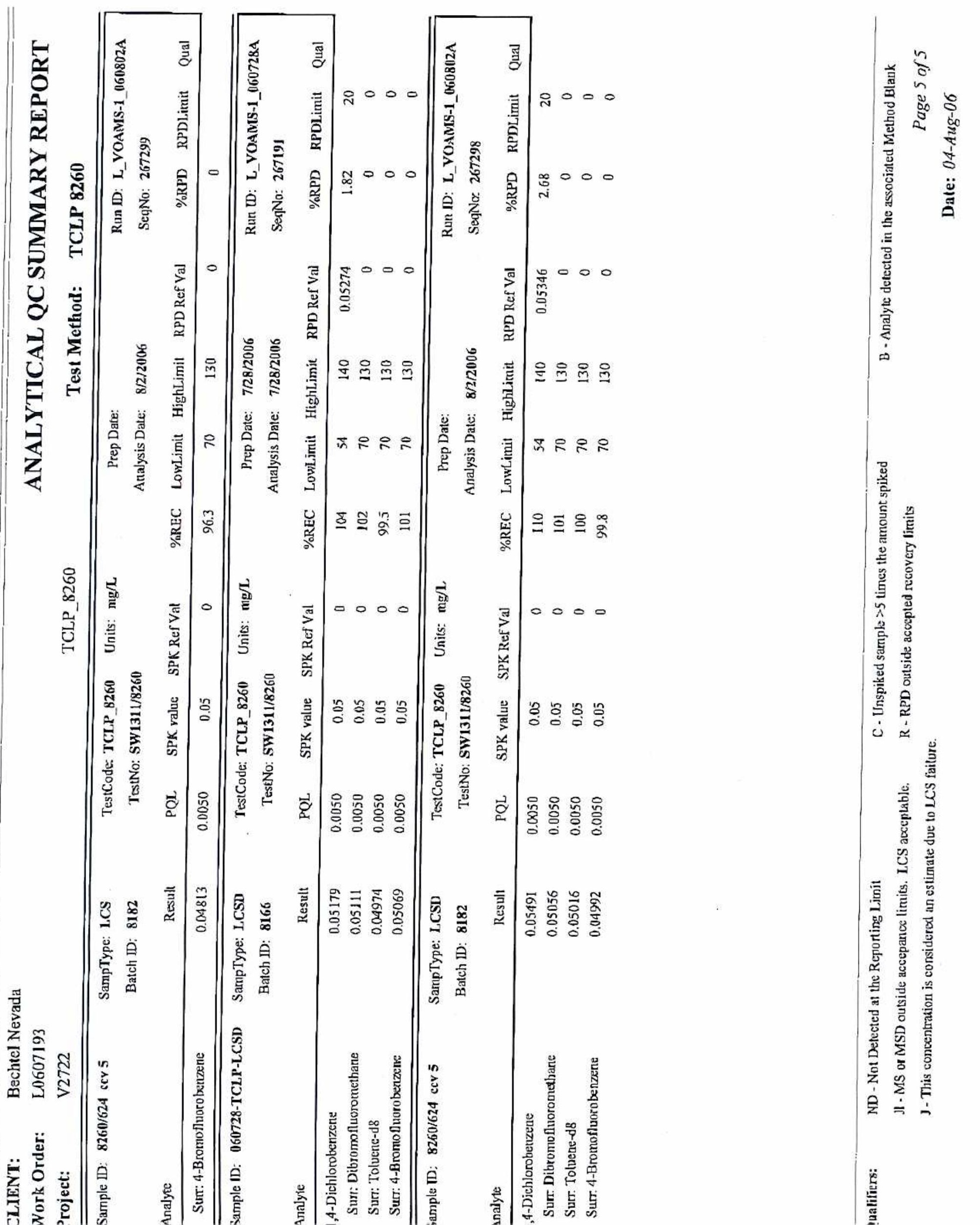




\section{Southwest Analytical, Inc.}

\section{Sample Receipt Checklist}

\section{Client Name BECNEV}

Work Order NumbQ L0607193

Checklist completed b

Matrix

Shipping container/cooler in good condition?

Custody seals intact on shippping container/cooler?

Custody seals intact on sample bottles?

Chain of custody present?

Chain of custody signed when rellnquished and received?

Chain of custody agrees with sample labels?

Samples in proper container/bottle?

Sample containers intact?

Sufficient sampla volume for indicated test?

All samples received within holding time?

Container/Temp Blank temperature in compliance?

Water - VOA vials have zero headspace?

Water - $\mathrm{pH}$ acceptable upon receipt?
Date and Time Receive

Received by CS.LV

Reviewed by
7/27/08 3:00:00 PM

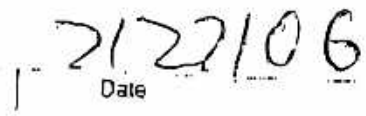

Carrier name Courier

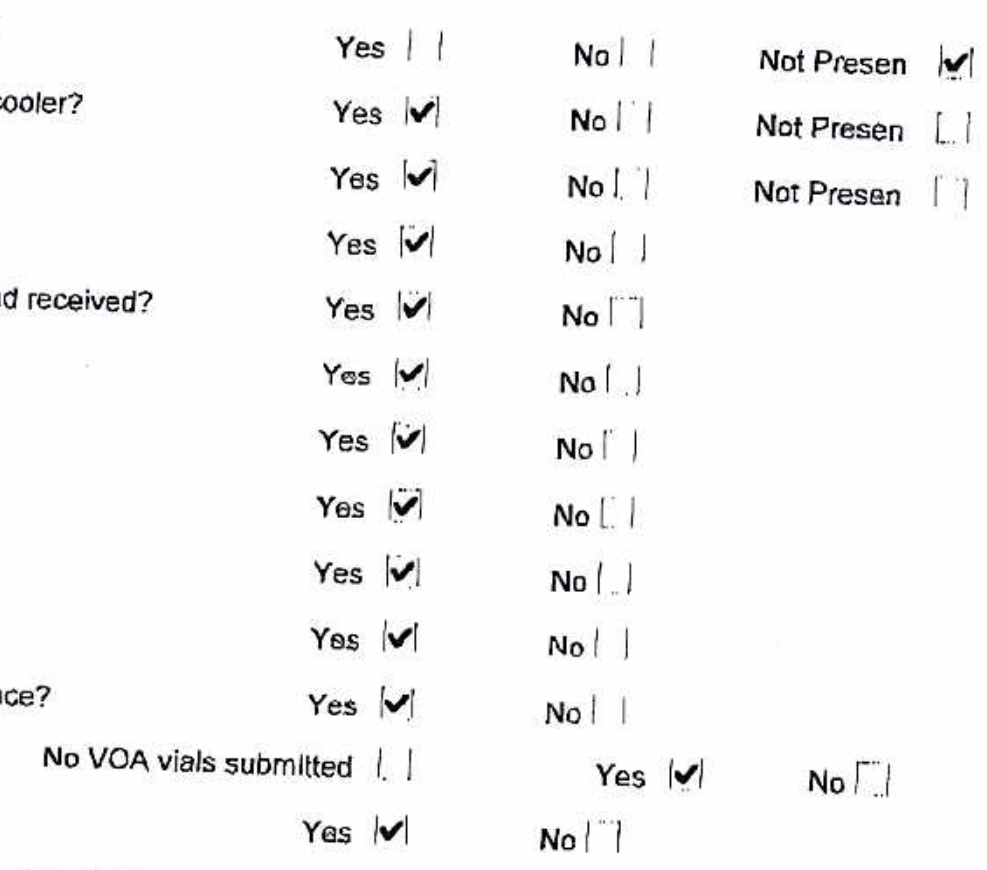

Adjusted?

Checked b

Any No and/or NA (not applicable) response must be detailed in the comments seclion b

Client contacted

Contacted by:

Comments:
Date contacted:

Regarding
Person contacted 


\section{Southwest Analytical, Inc. Earth Water A Air}

Remit To: Southwest Analytical, Inc Accounts Receivable 4208 Arcata Way, Suite A

N. Las Vegas, NV 89030

Phone- (702) 657-1010

Bill To: Bechtel Nevada P.O. Box 98521, M/S NSF025 Las Vegas, NV 89193-8521

Attn- Cathy Carey

Phone- (702) 295-1317

Project Name: V2722

Project Number:

Customer PO:

Report To: Bechtel Nevada

P.O. Box 98521, M/S NTS273

Las Vegas, NV 89193-8521

Attn- Kevin Campbell/Brad Jackson

Phons- (702) 295-5577

Fax- (702) 295-7761

\section{Invoice: $L 0607193$}

Invoice Date: August 04, 2006

Date Received: July 27, 2006

Sales Rapresentatlve: Word, Wayne

Quote Number: 200

Client ID: BECNEV

State Code:

\begin{tabular}{c|l|cc}
\hline Quanity & Description & Unit Prlce \\
\hline 4 & TCLP 8260 & $\$ 212.50$ & Extension \\
1 & TCLP RCRA 7 Metals (Soil) & $\$ 82.00$ & $\$ 850.00$ \\
2 & TCLP RCRA 8 (Soll) & $\$ 82.00$ & $\$ 180.25$ \\
1 & Volatile Organic Compounds by EPA 8260 (Aqueous) & $\$ 150.00$ & $\$ 150.00$
\end{tabular}

Thank You for Your Businesg.

\begin{tabular}{rr} 
Subtotal: & $\mathbf{\$ 1 , 4 4 2 . 5 0}$ \\
Discount: & $0.00 \%$ \\
Surcharge: & $0.00 \%$ \\
Misc Charges: & $\$ 0.00$ \\
\hline Payment Received: & $\$ 0.00$ \\
INvOICE Total: & $\$ 1, \mathbf{4 4 2 . 5 0}$
\end{tabular}
Net 30 days from Invoice Date. We accept Visa and Mastercard. Past due balances are subject to a finance Charge of $1.5 \%$ per month ( $18 \%$ per
year). Any adjustments to this invoice must be submitted within 30 days of Invoice Date. 


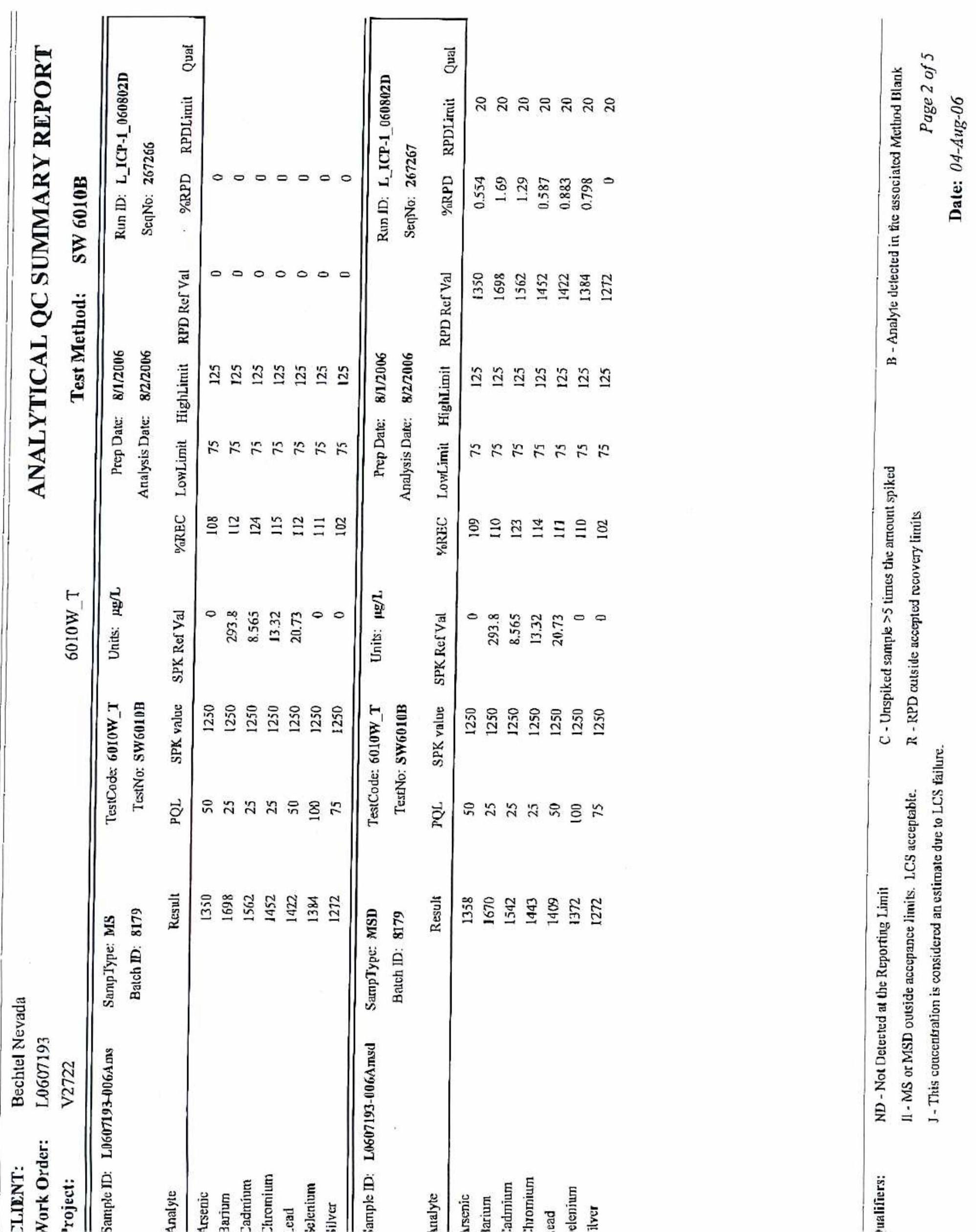




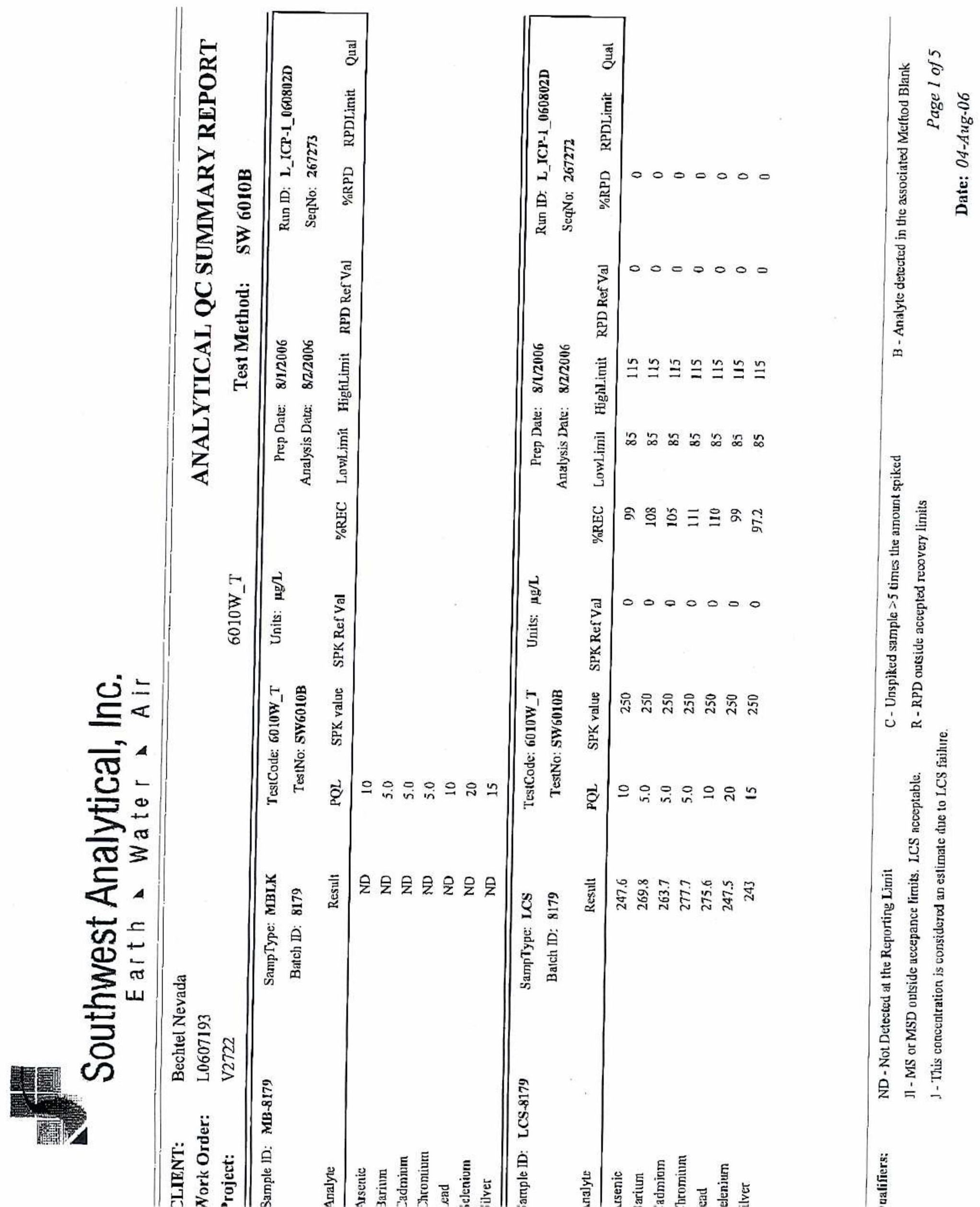


Southwest Analytical, Inc.

Date: $04-A u g-06$

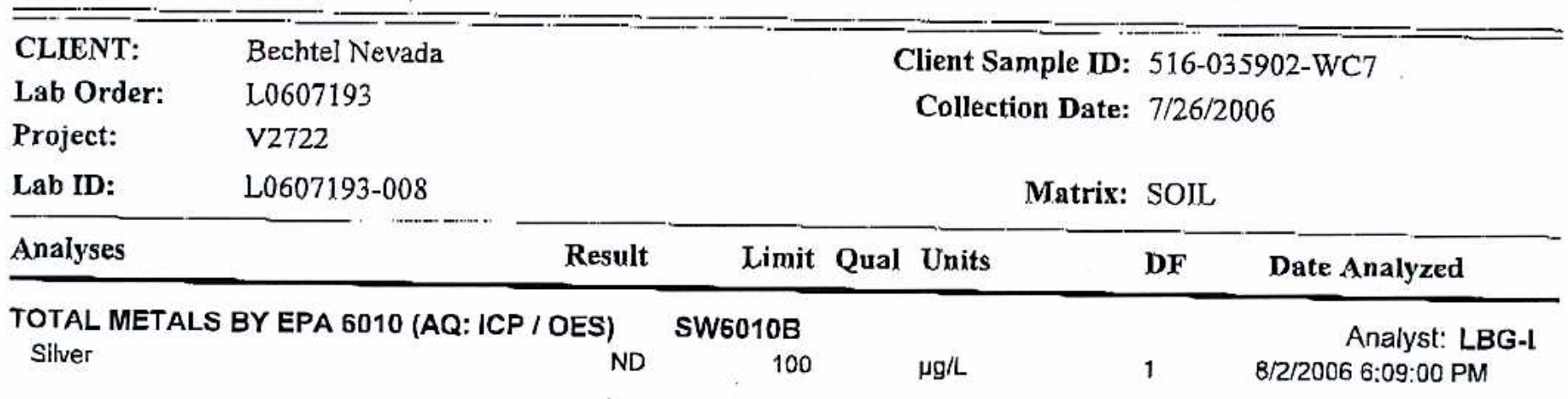


Southwest Analytical, Inc.

Date: $04-A u g-06$

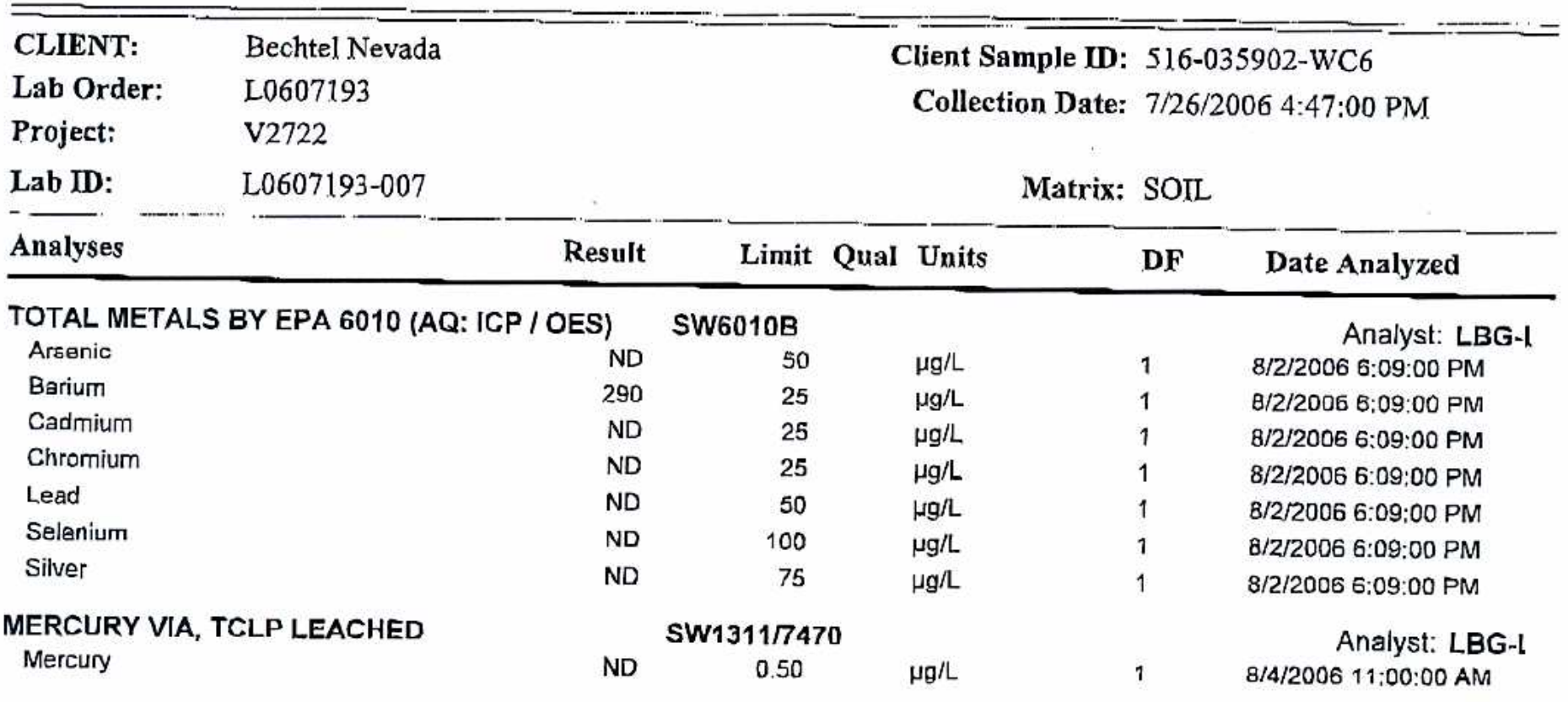


Southwest Analytical, Inc.

Date: 04-Aug-06

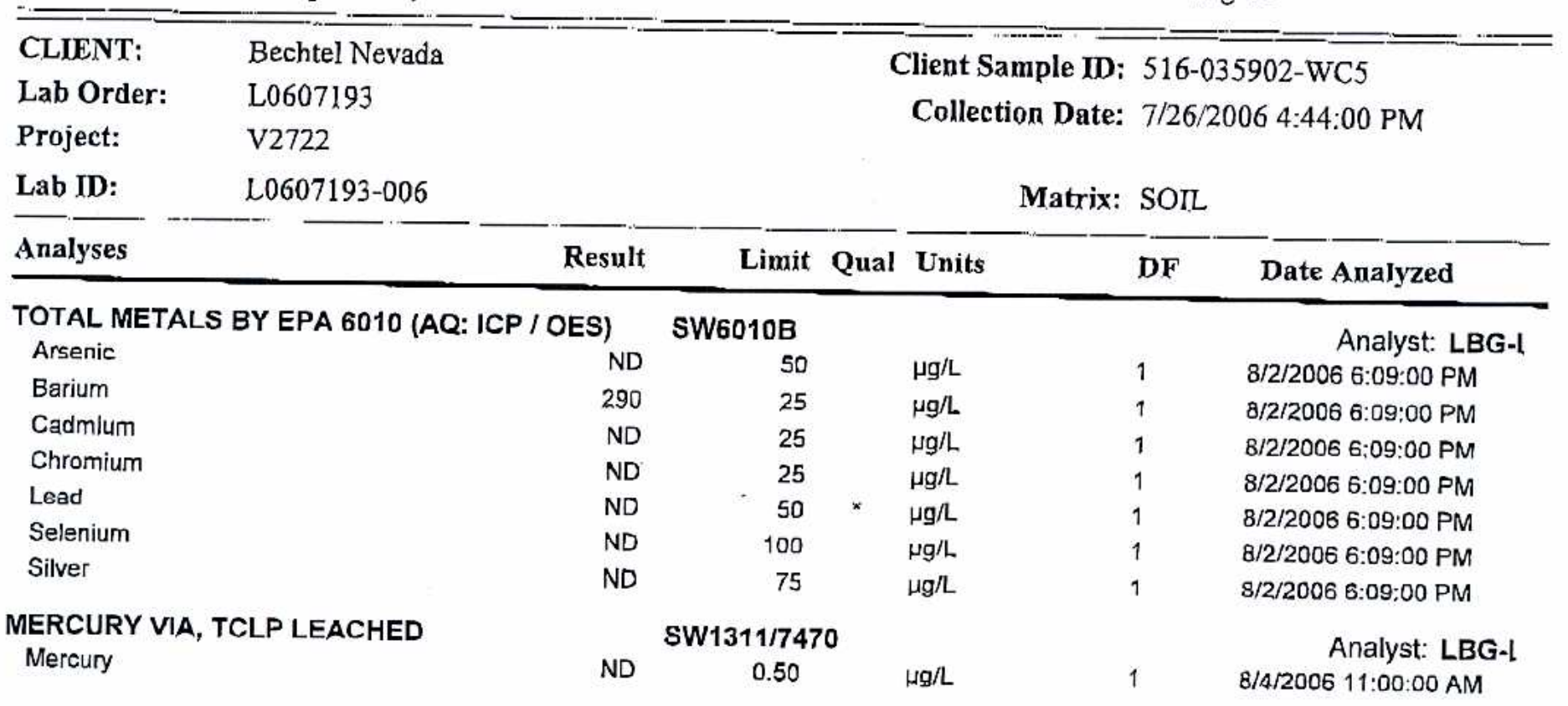


Southwest Analytical, Inc.

Date: 04-Aug-06

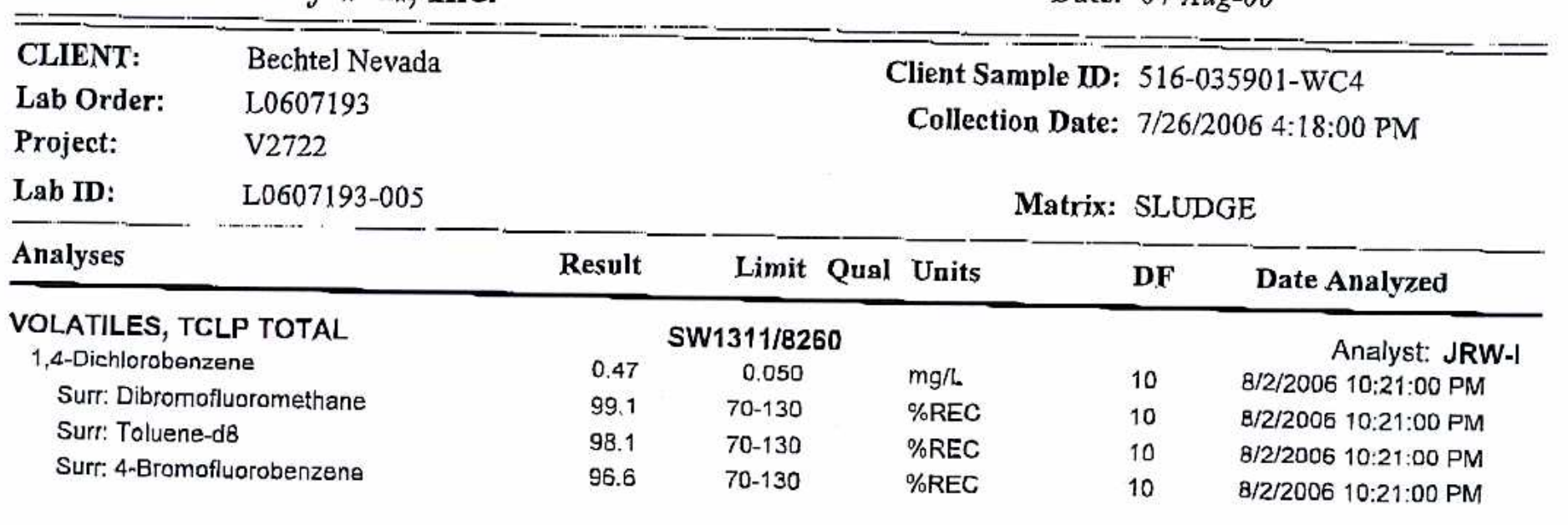




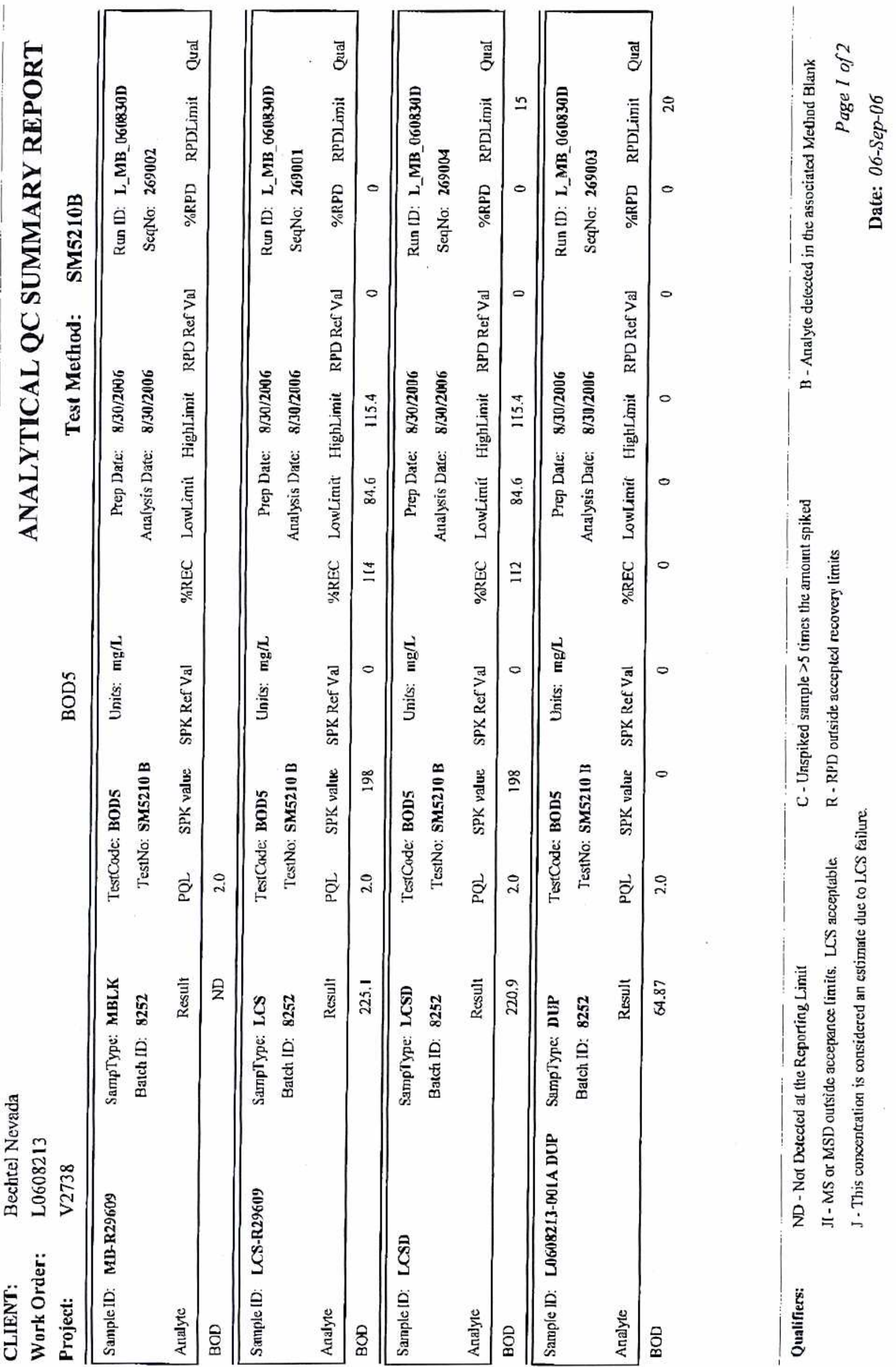



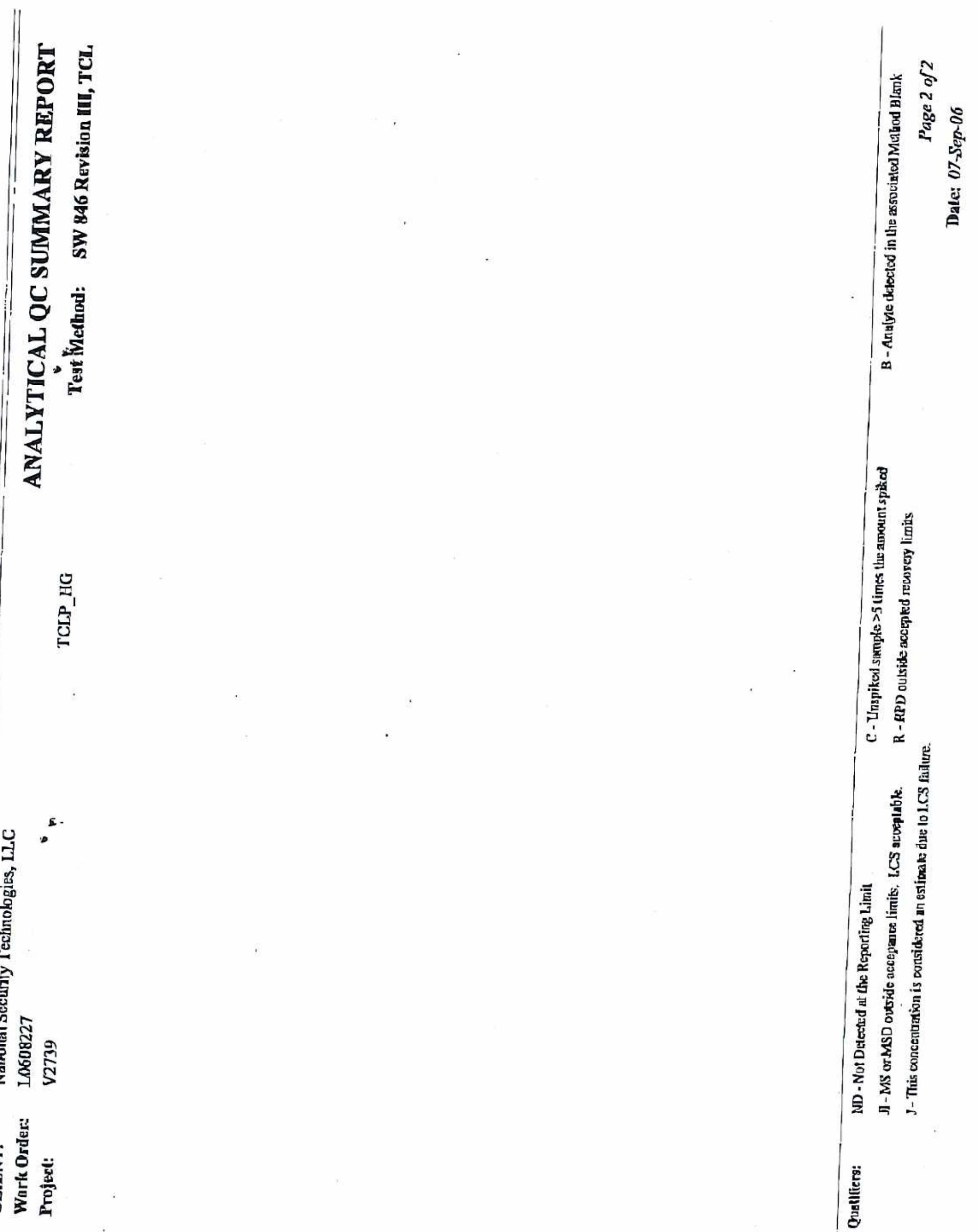


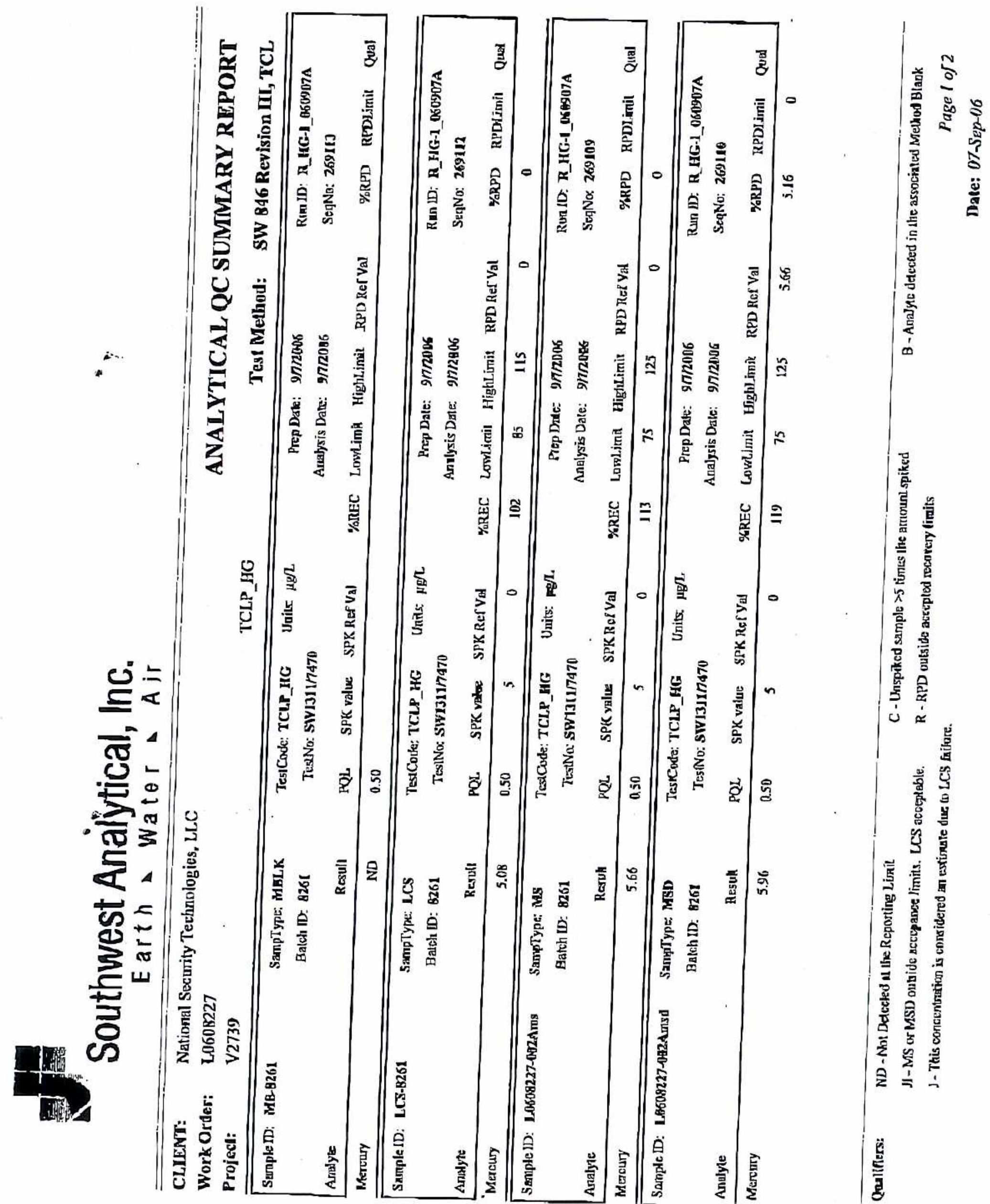


Southwest Analytical, Inc.

CLIENT: Narional Securicy Technologies, LLC

Lab Order: L0608227

Project: V2739

Lab ID: L0608227-002

Analyses

MERCURY VIA, TCLP LEACHED

Meroury

.
Date: 07-Sep-06

Client Sample ID: 065101-R1

Collection Date: 8/23/2006 11:40:00 AM

Matrix: AQUEOUS

$\begin{array}{ccccc}\text { Result } & \text { Limit Qual Units } & \text { DF } & \text { Date Analyzed } \\ \text { ND } \begin{array}{c}\text { SW1311/7470 } \\ 0.50\end{array} \quad \text { HglL. } & 1 & \text { Anglyst; LBG-L }\end{array}$


Southwest Analytical, Inc.

\section{CLIENT:}

Lab Order:

Project:

Lab TD:

National Security Technologies, LLC

L0608227

V2739

L0608227-001

$\frac{\text { Analyses }}{\substack{\text { MERCURY VIA, TCLP LEACHED } \\ \text { MerCUIY }}}$

Date: 07-Sep-06

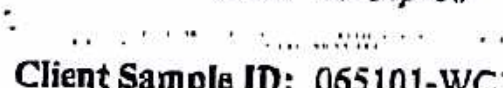

Client Sample [D: 065101-WC]

Collection Date: 8/23/2006 11:30:00 AM

Matrix: SOIL

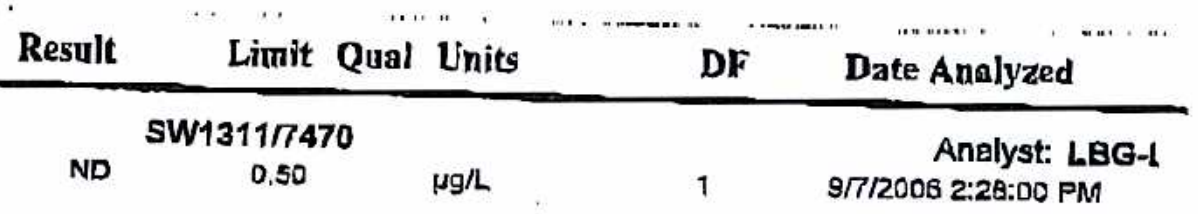

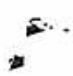


$2-$

Southwest Analytical, Inc.

Date: 07-Sep-06

.......

CLIENT: $\quad$ National Security Technologies, LLC

Project:

V2739

Lab Order: L0608227

\section{Work Order Sample Summary}

Lab Sample ID Client Sample ID

L0608227-001A 065101-WC1

L0608227-002A 065101-R1
Tag Number

Collection Date

8/23/2006 11:30:00 AM

$8 / 23 / 200611: 40: 00 \mathrm{AM}$
Date Roceived

$8 / 30 / 2006$

$8 / 30 / 2006$

2 
THIS PAGE INTENTIONALLY LEFT BLANK 


\section{APPENDIX C}

\section{WASTE DISPOSITION DOCUMENTATION}


THIS PAGE INTENTIONALLY LEFT BLANK 


\section{Bechtel Neradg NTSLandfiltogad}

Bechtel Nevada NTS Landfill Load Verification

(Waste definitions are available on page 2)

SWO USE (Circle One Area) AREA

For waste characterization, approval, andlor assistance, contact Șolid Was

REQUIRED: WASTE GENERATOR INFORMATION

(This form is for rolloffs,

Waste Generator: SHALGHiN BuRNisON

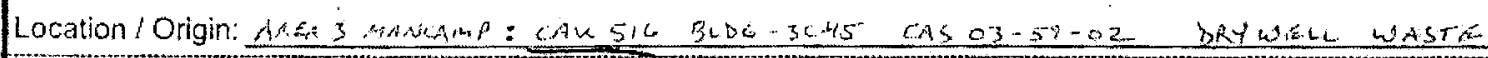

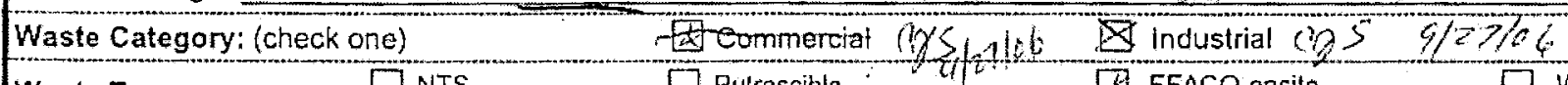

$\begin{array}{lllll}\text { Waste Type: } & \square \text { NTS } & \square \text { Putrescible } & \square \text { FFACO-onsite } & \square \text { WAC Exception } \\ \text { (check one) } & \square \text { Non-Putrescible } & \square \text { Asbestos Containing Material } & \square \text { FFACO-offsite } & \square \text { Historic DOEINV }\end{array}$

Pollution Prevention Category: (check one) $\quad \backslash$ Environmental management $\square$ Defense Projects

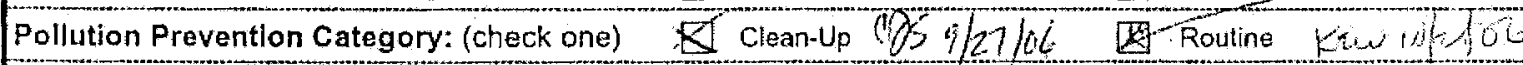

Method of Characterization: (check one) $\quad D$ Sampling \& Analysis $\square$ Process Knowiedge $\square$ Contents

Prohibited Waste Radioactive waste; RCRA waste; Hazardous waste; Free liquids, PCBs above TSCA regulatory levels-, and Medical at all three NTS landfills: wastes (needles, sharps, bloody clothing).

Additional Prohibited Waste Sewage Sludge; Animal carcasses-, Wot garbage (food waste); and Friable asbestos at the Area 9 U10c Landfill:

\section{REQUIRED: WASTE CONTENTS ALLOWABLE WASTES}

Check all allowable wastes that are contained within this load:

NOTE: Waste disposed at the Area 6 Hydrocarbon Landfill must have come into contact with petroleum hydrocarbons or coolants such as: gasoline (no benzene, lead): jet fuel; diesel fuel; lubricants and hydraulics; kerosene; asphaltic petroleum hydrocarbon; and ethylene glycol.
Acceptable waste at any NTS landfill:
$\square$ Asphalt $\square$ Metal
$\square$ Wood
$\square$ Paper
ه Rocks / unaltered geologic materials
$\square$ Empty containers
$\square$ Plastic
$\square$ Wire
[Cable
(x) Soil
$\square$ Cloth
$\square$ Rubber (excluding tires)
$\square$ Insulation (non-Asbestosform)
$\square$ Demolition debris
$\square$ Cement $\&$ concrete

Manufactured items: (swamp coolers, furniture, rugs, carpet, electronic components, PPE, etc.)

Additional waste accepted at the Area 23 Mercury Landfill: $\square$ Office waste $\square$ Food Waste $\square$ Animal Carcasses

$\square$ Asbestos: $\square$ Friable $\square$ Non-Friable (contact $S$ WO if regulated load) Quantity:

Additional waste accepted at the Area 9 บ10c Landfill:

$\square$ Non-friable asbestos $\quad \square$ Drained automobiles and military vehicles
$\square$ Light ballasts (contact SWO) $\square$ Drained fuel filters (gas \& diesel)

Hydrocarbons (contact SWO)

Additional waste accepted at the Area 6 Hydrocarbon Landfill:

$\square$ septic sludge $\square$ Rags

$\square$ Plants

$\square$ Drained fuel filters (gas \& diesel)

$\square$ Sludge from sand/oil/water separators

\section{Kaw w i \& \& \&}

Initials: (If initialed, no radiological clearance is necessary.)

The above mentioned waste was generated outside of a Controlled Waste Management Area (CWMA) and to the best of mv knowledge, does not contain radiological materials.

To the best of my knowledge, the waste described above contains only those mate site. / have verified this through the waste characterization method identified abov prohibited and allowable waste items.

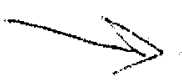

Print Name: SHaUgha BuRn,S Signature: Date: $\frac{7 / 26 / 2006}{7}$ Radjological Survey Release for Waste Disposal
RCT Inltials
This containerlload meets the criteria for no
added man-made radioactive material
This container/load meots the criteria for
Radcon Manual Table 4.2 rolease limits.
This container/loag'is exempt from survey
due to process kpowledge and origin. SIGNATURE: OATE: $(1,3) x$ BN-064E (10105)

Note: Food waste, office trash andior animal carcasses are considered not to contain adoed radioactivity, and therefore do not require a radiological clearance. 
For waste characterization, approval, andlor assistance, contact Solid. Waste Operation (SWO) at 5-7898.

\section{REQUIRED: WASTE GENERATOR INFORMATION}

(This form is for rolloffs, dump trucks, and other onsite disposal of materials.)

Waste Generator: Sifaugan Buanisan Phone Number: $5-7328$

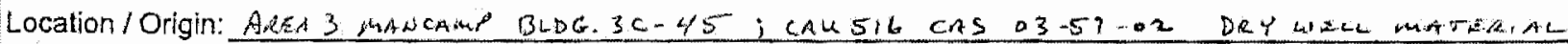

Waste Category: (check one)

Waste Type:

(check one)

ए NTS

$\square$ Non-Putrescible

$\square$ Commercial

[a] industrial

Pollution Prevention Category: (check one)

$\square$ Putrescible

Q FFACO-onsite

WAC Exception

Pollution Prevention Category: (check one)

$\square$ Asbestos Containing Material

D FFACO-otisite Hisloric DOE/NV

Method of Characterization: (check one)

A. Environmental management

D. Defense Projects

Prohibited Waste

[a] Clean- Up

(b) Sampling \& Analysis

[ Routine

at all three NTS landfills: wasles (needies, sharps, bloody clothing).

Additional Prohibited Waste Sewage Sludge: Animal carcasses-, Wet garbage (food waste); and Friable asbestos at the Area 9 U $10 \mathrm{c}$ Landfill:

REQUIRED: WASTE CONTENTS ALLOWABLE WASTES

Check all allowable wastes that are contained within this load:

NorE: Waste disposed at the Area 6 Hydrocarbon Landfill must have come inlo contact with pelroleum hydrocarbons or coolants such as: gasoline (no benzene, lead); jel fuel; diesel fuel; lubricants and hydraulics; kerosene; asphaltic petroleum hydrocarbon; and ethylene glycol

Acceptable waste at any NTS landfill: $\square$ Paper $\square$ Rocks / unaltered geologic materials
$\square$ Asphalt
Metal
$\square$ Wood
a soil
$\square$ Rubber (excluding tires)
$\square$ Plastic
$\square$ Wire
$\square$ Cable
[] Cloth
$\square$ Insulation (non-Asbestosform)
$\square$ Demolition debris

Empty containers

$\square$ Manufactured items: (swamp coolers, furniture, rugs, carpet, electronic components, PPE, etc.)

Additional waste accepted at the Area 23 Mercury Landfill: $\square$ Office waste $\square$ Food Waste $\square$ Animal Carcasses

$\square$ Asbestos: $\square$ Friable $\square$ Non-Friable (confact $S W O$ if regulated load) Quantity:

Additional waste accepted at the Area 9 U10c Landfill:
Won-friable asbestos
$\square$ Drained automobiles and military vehicles
Solid fractions from sand/oil/water separators
$\square$ Light ballasts (contact SWO)
$\square$ Drained fuel filters (gas \& diesel)
Deconned Underground and Above Ground
$\square$ Hydrocarbons (contact SWO)
Tanks

Additional waste accepted at the Area 6 Hydrocarbon Landfill:
$\square$ Septic sludge $\square$ Rags
$\square$ Drained fuel filters (gas \& diesel)
Crushed non-terne plated oil filters
Delants

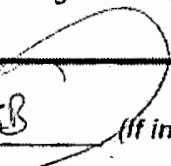
Initials: $S B$ (f) initialed, no radiological clearance is necessary.)
$\square$ sludge from sand/oil/water separators
$\square$ PCBs below 50 parts per million

The above mentioned waste was generated outside of a Controlled Waste Management Area (CWMA) and to the best of my knowledge, does not contain radlologlcal materials.

To the best of my knowledge, the waste described above contains only those mi. site. I have verified this through the waste characterization method identified ab. prohibited and allowable waste items.

Print Name: SHALGHA Burnison

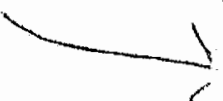

Signature: Date: $5 / 12 / 06$

Radiological Survey Release for Waste Disposal RCT Initials

This container/load meots the criterla for no added man-made radloactive material

(1) This containerload meets the criteria for Radcon Manual Tab i 4.2 release limits. This contalnerliofd is exempt from survey due to propess knowedge and arigin.

SIGNATURE: DATE $\angle 0.3 . C$ 3N-0646(1005)

Note: Food waste, office trash and/or animal carcasses are considered not to contain acded radioactivity, and thererore do not require a radiological clearance.

SWO USE ONLY

Load Weight (net from scale on estimate): 30550

githet

Signature of Certifier. 
For waste characterization, approval; andlor assistance, contact Solid Waste Operation (SWO) at 5-7898.

$$
\text { REQUIRED: WASTE GENERATOR INFORMATION }
$$

(This form is for rolloffs, dump trucks, and other onsite disposal of materials.)

Waste Generator: SHAUGHO BuRNISON Phone Number: $5-9328$

Location/Origin: ARCA 3 MANCAMP BLDK 3C-45; CAK 516 CAS O3-59-02 DRYWELL MAAERML

\begin{tabular}{llll} 
Waste Category: (check one) & $\square$ Commercial & $\square$ Industrial \\
$\begin{array}{llll}\text { Waste Type: } \\
\text { (check one) }\end{array}$ & $\square$ NTS & $\square$ Putrescible & $\square$ FFACO-onsite \\
\hline
\end{tabular}

Pollution Prevention Category: (check one) $\quad$ Q Environmental management $\square$ Defense Projecls

Pollution Prevention Category: (check one) $\square$ Clean- $U_{p} \quad \square$ Routine

Method of Characterization: (check one) $\square$ Sampling \& Analysis $\square$ Process Knowledge $\square$ Conlents
$\begin{array}{ll}\begin{array}{l}\text { Prohibited Waste } \\ \text { at all three NTS landfills: }\end{array} & \begin{array}{l}\text { Radioactive waste: RCRA waste; Hazardous waste; Free liquids, PCBs above TSCA regulatory levels-, and Medica } \\ \text { wasles (needles, sharps, bloody clothing). }\end{array}\end{array}$

Additional Prohibited Waste Sewage Sludge; Animal carcasses-, Wet garbage (food waste); and Friable asbeslos at the Area 9 U10c Landfill:

\section{REQUIRED: WASTE CONTENTS ALLOWABLE WASTES}

Check all allowable wastes that are contained within this load:

NOTE: Waste disposed at the Area 6 Hydrocarbon Landfil must have come into contact with patroleum hydrocarbons or coolants such as: gasoline (no benzene, lead); jet fuel; diesel fuel; fubricants and hydraulics; kerosene; asphaltic pelroleum hydrocarbon; and ethylene glycol.

Acceptable waste at any NTS landfill: $\square$ Paper $\quad \propto$ Rocks/ unaltered geologic materials $\square$ Empty containers
$\square$ Asphalt
$\square$ Metal
$\square$ Wood
[x] Soil
$\square$ Rubber (excluding tires)
Demolition debris
$\square$ Plastic
$\square$ Wire
$\square$ Cable $\square$ Cloth
$\square$ Insulation (non-Asbestosform)
Cement \& concrete
$\square$ Manufactured items: (swamp coolers, furniture, rugs, carpet, electronic components, PPE, etc.)

Additional waste accepted at the Area 23 Mercury Landfill: $\square$ Office waste $\square$ Food Waste $\square$ Animal carcasses

$\square$ Asbestos: $\square$ Friable $\square$ Non-Friable (contact $\$$ WO if regulated load) Quantity:

Additional waste accepted at the Area 9 ע10c Landfill:
$\square$ Non-friable asbestos
$\square$ Drained aulomobiles and military vehicles
$\square$ Light ballasts (contact SWO)
$\square$ Drained fuel filters (gas \& diesel)
$\square$ Hydrocarbons (contact SWO)

Additional waste accepted at the Area 6 Hydrocarbon Landfill:
$\square$ Septic sludge $\square$ Rags
$\square$ Drained fuel filters (gas \& diesel)
$\square$ Sludge from sand/oil/water separators

Solid fractions from sand/oil/water separators Deconned Underground and Above Ground Tanks KCW $10 / 3 / 6$ REQUIRED: WASTE GENERATOR SIGNATURE

Initials: $\$ B$ IIf

The abbve mentioned waste was generated outside of a Controlled Waste Management Area (CWMA) and to the best of my knowledge, does not contain radiological materials.

To the best of my knowledge, the waste described above contains only those $m$ site. I have verlfied this through the waste characterization method identified ab prohibited and allowable waste items.

Print Name: Stakchin Buratison

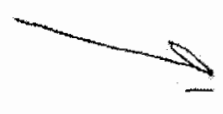

Signature:

Date: $9 / 12 / 06$

Radiological Survey Release for Wasto Disposal RCT Initials

- This contaneriload meets the criteria for no

added man-made radioactive material

QU. This containeifload meets the criterla for

Radcon Manua/Table 4.2 release IImits.

This contahinglioad is exempt from survey

due to procoss knowledge and origin. SIGNATURE: DATE: 0.26 BN-0646 (10;05)

Note: Food waste, office trash and/or animal carcasses are considered not to contain added radioactivity, and therefore do not require a radiological clearance.

SWO USE ONLY

Load Weight (net from scale dr estimate)

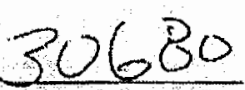

Signature of Certifier. 


\section{SWO USE (Circle One Area) AREA \\ 23 \\ 6 \\ $9 \longdiv { \text { LANDFI } }$ \\ For waste characterization, approval, and/or assistance, contact Solid Waste Operatton (SWO) at 5-7898.}

\section{REQUIRED: WASTE GENERATOR INFORMATION}

(This form is for rolloffs, dump trucks, and other onsite disposal of materials.)

Waste Generator: SHALGHN BuRNISON

Phone Number: $5-9328$

Location/Origin: CAW 516 CAS 03-57-02 AKEA 3 MANCAMP BLDG 3C-45 DRY WELL MATERIAL

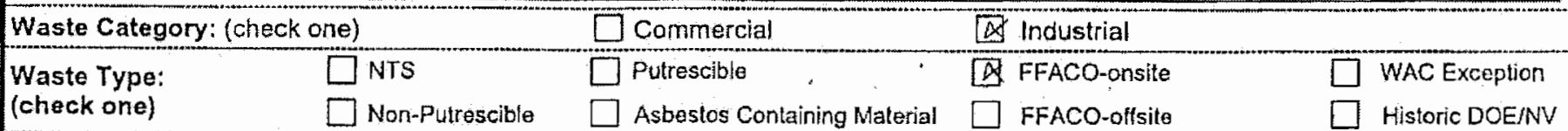

Pollution Prevention Category: (check one) $\triangle$ Environmental management $\square$ Defense Projects

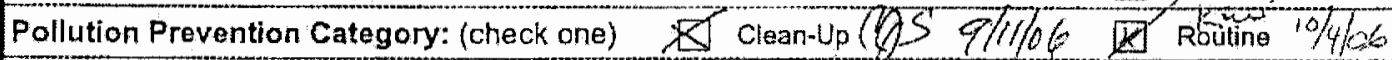

Method of Characterization: (check one) $\quad$ ) Sampling \& Analysis $\square$ Process Knowledge $\square$ Contents

Prohibited Waste Radioactive waste; RCRA waste; Hazardous wasle; Free liquids, PCBs above TSCA regulatory levels-, and Medical at all three NTS landfills: wastes (needles, sharps, bloody clothing).

Additional Prohibited Waste Sewage Sludge; Animal carcasses-, Wet garbage (food waste); and Friable asbeslos at the Area 9 U10c Landfill:

\section{REQUIRED: WASTE CONTENTS ALLOWABLE WASTES}

Check all allowable wastes that are contained within this load:

NOTE: Waste disposed at the Area 5 Hydrocarbon Landfill must have come into contact with petroleum hydrocarbons or coolants such as: gasoline (no benzene, lead); jet fuel; diesel fuel; lubricants and hydraulics; kerosene; asphallic pelroleum hydrocarbon; and ethylene glycol.

Acceptable waste at any NTS landfill:

$\square$ Paper

X. Rocks/unaltered geologic materials

$\square$ Empty containers
$\square$ Asphalt
$\square$ Metal
$\square$ Wood
Q Soll
$\square$ Rubber (excluding tires)
$\square$ Plastic
$\square$ Wire
$\square$ Cable $\square$ Cloth
$\square$ Insulation (non-Asbestosform)
$\square$ Demolition debris

$\square$ Manufactured items: (swamp coolers, furniture, rugs, carpet, electronic components, PPE, etc.)

Additional waste accepted at the Area 23 Mercury Landfill: $\square$ Office waste $\square$ Food Waste $\square$ Animal Carcasses

Asbestos: $\square$ Friable $\square$ Non-Friable (contact SWO if regulated load) Quantity:

Additional waste accepted at the Area 9 U10c Landfill:
$\square$ Non-friable asbestos
Drained automobiles and military vehicles
Solid fractions from sand/oil/water separators
$\square$ Light ballasts (contact SWO)
Drained fuel filters (gas \& diesel)
Deconned Underground and Above Ground
Hydrocarbons (contact SWO)
Tanks

Additional waste accepted at the Area 6 Hydrocarbon Landfill:
$\square$ Septic sludge $\square$ Rags
$\square$ Drained fuel filters (gas \& diesel)
Crushed non-terne plated oil filters
QPlants
$\square$ Sludge from sand/ail/water separators
PCBs below 50 parts per million

Initials: $8 \%$ (If initialed, no radiological clearance is necessary.)

The above mentioned waste was generated outside of a Controlled Waste Manag knowledge, does not contain radiological materials.

To the best of my knowledge, the waste described above contains only those ma site. I have verified this through the waste characterization method identified abs prohibited and allowable waste items.

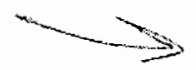

Print Name: Shaughn Burnison

Signature

Date: $9 / 7 / 06$

Radiological Survay Release for Waste Disposal RCT Initials

This containerload meats the criteria for no added man-mado radioactivo materlal

cal This containeriload meets the criteria for Radcon Manual Jable 4,2 release limits. This contalneribad is exempt from survey due lo progess knowledge and origin SIGNATURE: DATE: $10 \cdot 3 \cdot 04$ BN-0.0646(10/05)

Note: Food waste, office trash and/or animal carcasses are considered not to contain added radioactivity, and therefore do not require a radiological clearance.

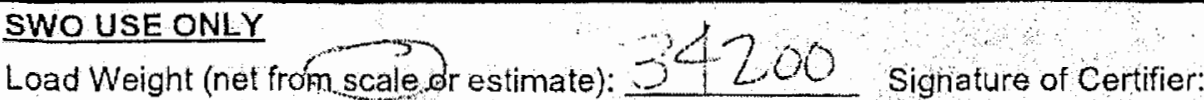




\section{Bechtel Nevada NTS Landfill Load Verification}

(Waste definitions are avallable on page 2)

\section{SWO USE (Circle One Area) AREA 23}

For waste characterization, approval, andlor assistance, contact Solid Waste Operation (SWO) at 5-7898.

\section{REQUIRED: WASTE GENERATOR INFORMATION}

(This form is for rolloffs, dump trucks, and other onsite disposal of materials.)

Waste Generator: Straugtin Buinison

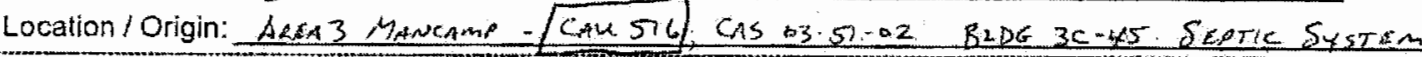

\begin{tabular}{|c|c|c|c|c|}
\hline \multicolumn{2}{|c|}{ Waste Category: (check one) } & \multicolumn{3}{|c|}{ Commercial $\quad$ Industrial } \\
\hline \multirow{2}{*}{$\begin{array}{l}\text { Waste Type: } \\
\text { (check one) }\end{array}$} & $\square$ NTS $/ 0 S$ & Putrescible & GDEFACO-onsite & WAC Exception \\
\hline & ano-Pundescihlo & Asbestos Containing Material & $\square$ FFACO-offsite & Historic DOE/NV \\
\hline
\end{tabular}

Pollution Prevention Category: (check one)

Pollution Prevention Category: (check one)

Q Environmental management

$\square$ Defense Projects

Method of Characterization: (check one)

$\triangle$ Clean-up $(05.9 / 5 / 66$

(ג) Routine

Prohibited Waste Radioactive waste; RCRA waste; Hazardous waste; Free liquids, PCBs above TSCA regulalory levels-, and Medical at all three NTS landfills: wastes (needles, sharps, bloody clothing).

Additional Prohibited Waste Sewage Sludge; Animal carcasses-, Wet garbage (food waste); and Friable asbestos at the Area 9 U10c Landfill:

\section{REQUIRED: WASTE CONTENTS ALLOWABLE WASTES}

Check all allowable wastes that are contained within this load;

NOTE: Waste disposed at the Area 6 Hydrocarbon Landfill must have come into contact with petroleum hydrocarbons or coolants such as: gasoline (no benzene, lead); jet fuel; diesel fuel; lubicants and hydraulics; kerosene; asphaltic petroleum hydrocarbon; and ethylene glycol.

Acceptable waste at any NTS landfill: $\square$ Paper $\square$ Rocks / unaltered geologic materials

$\square$ Asphalt $\square$ Metal $\square$ Wood $\square$ soil $\square$ Rubber (excluding lires)

Q Plastic $\square$ Wire $\square$ Cable $\square$ cloth $\square$ Insulation (non-Asbestosform)

$\square$ Emply containers

$\square$ Manufaclured items: (swamp coolers, furniture, rugs, carpet, electronic components, PPE, etc.)

Additional waste accepted at the Area 23 Mercury Landflil: $\square$ Office waste $\square$ Food Waste $\square$ Animal Carcasses

$\square$ Asbestos: $\square$ Friable $\square$ Non-Friable (contact SWO if regulated load) Quantity:

Additional waste accepted at the Area 9 U10c Landfill:

$\square$ Non-friable asbestos

Light ballasts (contact SWO)

Hydrocarbons (contact SWO)

Additional waste accepted at the Area 6 Hydrocarbon Landfill:
$\square$ Septic sludge $\square$ Rags
$\square$ Drained fuel filters (gas \& diesel)
$\square$ Sludge from sand/oil/water separators
$\square$ Plants

Drained automobiles and military vehicles

Solid fractions from sand/oil/water separators Drained fuel filters (gas \& diesel)

$\square$ Deconned Underground and Above Ground Tanks Initials: $\$ 3$ REQUIRED: WASTE GENERATOR SIGNATURE (If initialed, no radiological clearance is necessary.)

The above mentioned waste was generated outside of a Controlled Waste Management Area (CWMA) and to the best of my knowledge, does not contain radiological materials.

To the best of my knowledge, the waste described above contains only those materials that are allowed for disposal at this site. I have verified this through the waste characterization method identifled above and a review of the above-mentioned prohibited and allowable waste items.

Print Name: SHaughN BupN,Son

Signature: Date: $8 / 3) / 06$

If applicable, place BN-0646,

"Radiological Release Sticker" here. Onsite use only.

Note: Food waste, office trash and/or animal carcasses are considered not to contain added radioactivity, and therefore do not require a radiological clearance.

\section{SWO USE ONLY}

Load Weight (net from scale or estimate)
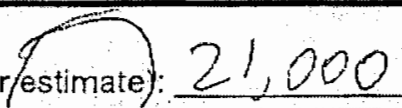

$\$|3| / 06$

Signature of Certifier

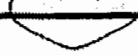


For waste characterization, approval, andlor assistance, contact Solid Waste Operation (SWO) at 5-7898.

\section{REQUIRED: WASTE GENERATOR INFORMATION}

Waste Generator: SHAverin RuRnison (This form is for rolloffs, dimp trucks, and other onsite disposal of materials.)

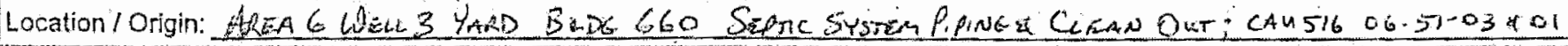

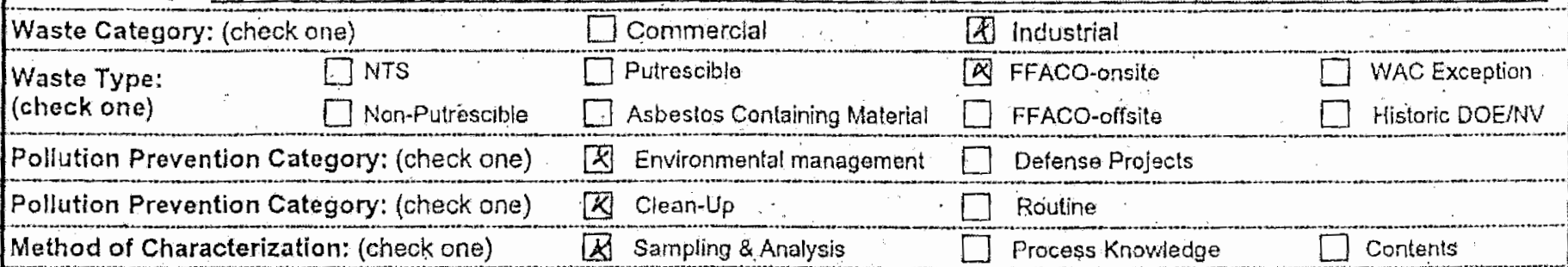
Prohibited Waste Radioactive waste; RCRA waste; Hazardous waste; Free liquids, PCBs above TSCA regulatory levels-, and Medical at all thre NTS landfills: wastes (needles, sharps, bloody ciothing).

Additional Prohibited Waste Sewage Sludge; Animal carcasses., Wel garbage (Tood waste); and Friable asbestos at the Area 9 U10c Landfill:

REQUIRED; WASTE CONTENTS ALLOWABLEWASTES

Check all allowable wastes that are contained within this load:

NOTE: Waste disposed at the Area 6 Hydrocarbon Landill must have come into contact with petroleum hydrocarbons or coolants such as: gasoline (no benzene, lead) jel fuel; diesel fuel; fubricants and hydraulics; kerosene; asphaltic petroleum hydrocarbon: and ethylene glycol, Acceptable waste at any NTS landfill:
$\square$ Paper
Da Rocks/unaltered geologio materials
[. Emply containers
Asphalt $\quad \square$ Metal $\square$ Wood $\square$ Soll.
$\square$ Plastic
[Wire
$\square$ Cable $\square$ Cloth.
$\square$ Rubber (excluding tires)
$\square$ insulation (nori-Asbestosform)
[] Demolition debris
Q Cement \& concrete

G Manufactured items: (swarnp coolers, furniture, rugs, carpel, electronic components, PPE, etc.)

Additional waste accepted at the Area 23 Mercury Landfill: $\square$ Office weste $\square$ Food Waste $\square$ Animal Carcasses

$\square$ Asbestos: $\square$ Friable $\square$ Non-Friable (contact Swo if regulated load) Quantity:

Additional waste accepted at the Area 9 Utoc Landfill:
Z Non-friable asbestos
$\square$ Drained automobiles and milltary vehicles
Solid fractions from sand/oll/water separators
I] Light ballasts (contact SWO)
$\square$ Drained fuel filters (gas \& diesel)
[Deconned Underground and Above Ground
DHydrocaibons (contact SWO)
[.] Tanks

Additional waste accepted at the Area 6 Hydrocarbon Landfill:
$\square$ septic sludge $\square$ Rags.
$\square$ Drained fuel filters (gas $\&$ dieseil)
IPlants
$\square$ Sludge from sand/oilwater separators
Crushed mon-terne plated oil filters
PCBs below 50 parts per million

nitials: $S B \quad$ (if intia/ad, no radiological clearance /s necessary.)

he above mentloned waste was generated outside of a Controlied Waste Management Area (CWMA) and to the best of my nowledge, does not contain radiological materiais.

o the best of my knowledge, the waste described above contains only those materials that are allowed for disposal at this te. I have veriffed this through the waste characterlzation method identiffed above and a review of the above-mentioned. ohibited and allowable waste items.

int Name: SHAugin BuRNison

If applicable, place BN-0646,

"Radiological Release Sticker" here: Onsite use only.

mature: Date: $19-4-06$

te: Food waste, office trash andior animal carcasses are considered not to contain added radioactivity, and therefore do not require a radiological clearance.

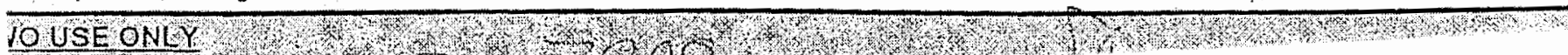

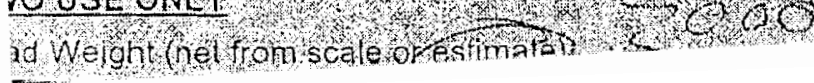




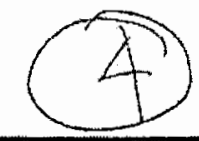

\section{Bechtel Nevada NTS Landfill Load Verification}

(Waste definitions are available on page 2)

\section{SWO USE (Circle One Area) AREA $23 \quad 6 \quad(19)$ LANDFILL}

For waste characterization, approval, andlor assistance, contact Solid Waste Operation (SWO) at 5-7898.

\section{REQUIRED: WASTE GENERATOR INFORMATION}

(This form is for rolloffs, dump trucks, and other onsite disposal of materials.)

Waste Generator: SHA TuCHN BuRNISON

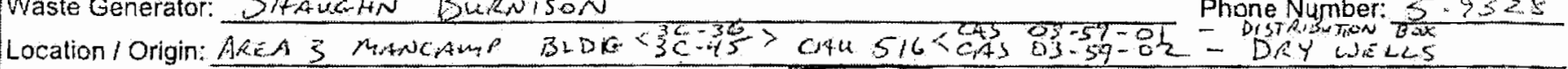

Waste Category: (check one) प Commercial DA Industrial

Waste Type: $\square$ NTS $\square$ Putrescible $\triangle$ FFACO-onsite $\square$ WAC Exception

Pollution Prevention Category: (check one) E Environmental management $\square$ Defense Projects

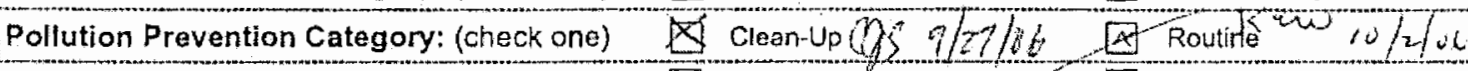

Method of Characterization: (check one) $\square$ Sampling \& Analysis $\square \square$ Process Knowledge $\square$ Contents

Prohibited Waste Radioactive waste; RCRA waste; Hazardous waste; Frea liquids, PCBs above TSCA regulatory levels-, and Medical

at all three NTS landfills: wastes (needles, sharps, bloody clolhing).

Additional Prohibited Waste Sewage Sludge: Animal carcasses-, Wet garbage (food waste); and Friable asbestos at the Area 9 U10e Landfill:

\section{REQUIRED: WASTE CONTENTS ALLOWABLE WASTES}

Check all allowable wastes that are contained within this load:

NOTE: Wasle disposed at the Area 6 Hydrocarbon Landfill nust have come into contact with petroleum hydrocarbons or coclants such as: gasoline (no benzene, lead); jel fuel; diesel fuel; lubricants and hydraulics; kerosene; asphaltic peltoleum hydrocarbon; and ethylene glycol

Acceptable waste at any NTS landfill: $\square$ Paper $\square$ Rocks / unaltered geologic materials $\square$ Empty containers
$\square$ Asphalt
$\square$ Metal
$\square$ Wood
Soil
$\square$ Rubber (excluding tires)
$\square$ Demolition debris

$\square$ Plastic

$\square$ Wire

$\square$ Cable $\square$ Cloth

$\square$ Insulation (non-Asbestosiorm)

E Cement \& concrete

Manufactured items: (swamp coolers, furniture, rugs, carpet, electronic components, PPE, etc.)

Additional waste accepted at the Area 23 Mercury Landfill: $\square$ Office waste $\square$ Food Waste $\square$ Animal Carcasses

Asbesios: $\square$ Friable $\square$ Non-Friable (contact SWO if regulated load) Quantity:

Additional waste accepted at the Area 9 U10c Landfill:
$\square$ Non-friable asbestos
$\square$ Drained automobiles and military vehicles
Light ballasts (contact SWO)
Drained fuel filters (gas $\&$ diesel)
Solid fractions from sand/oil/water separators
$\square$ Hydrocarbons (contact SWO)
Deconned Underground and Above Ground
Tanks

Additional waste accepted at the Area $\mathbf{6}$ Hydrocarbon Landfill:
$\square$ Septic sludge $\square$ Rags
$\square$ Drained fuel filters (gas \& diesel)
$\square$ Septic
$\square$ sludge from sand/oil/water separators
Crushed non-terne plated oil filters
PCBs below 50 parts per million

Initials: REQUIRED: WASTE GENERATOR SIGNATURE

The above mentioned waste was generated outside of a Controlled Waste Management Area (CWMA) and to the best of my knowledge, does not contain radiological materials.

To the best of my knowledge, the waste described above contains only those mal site. I have verified this through the waste characterization method identified abo: prohibited and allowable waste items.

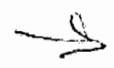

Print Name: Suancitn Bu, Enisan

Signature:___.... Date: $7 / 26 / 06$

Radiological Survey Release for Waste Disposal RCT Initials

This conteinerfload meats the criteria for no added man-made radioactive material

Cin This containerlload meets the criteria for Radcon Manual Tablo 4,2 release limits. This containeriload is oxempt from survey due to proces $/$ knowledge and origin.

SIGNATURE DATE: $10 ; \& 4$

Note: Food waste, office trash and/or animal carcasses are considered not to contain added radioactivity, and therefore do not require a radiological clearance.

SWO USE ONLY

Load Weight (net from scale dr estimate): 39500 signature of Certifier: 8 N.0646 (10105) 


\section{Bechtel Nevada NTS Landfill Load Verification}

(Waste definitions are available on page 2)

SWO USE (Circle One Area) AREA $23 \quad$ (6) 9 LANDFILL

For waste characterization, approval, and/or assistance, contact Solid Waste Operation (SWO) at 5-7898.

REQUIRED: WASTE GENERATOR INFORMATION

(This form is for rolloffs, dump trucks, and other onsite disposal of materials.)

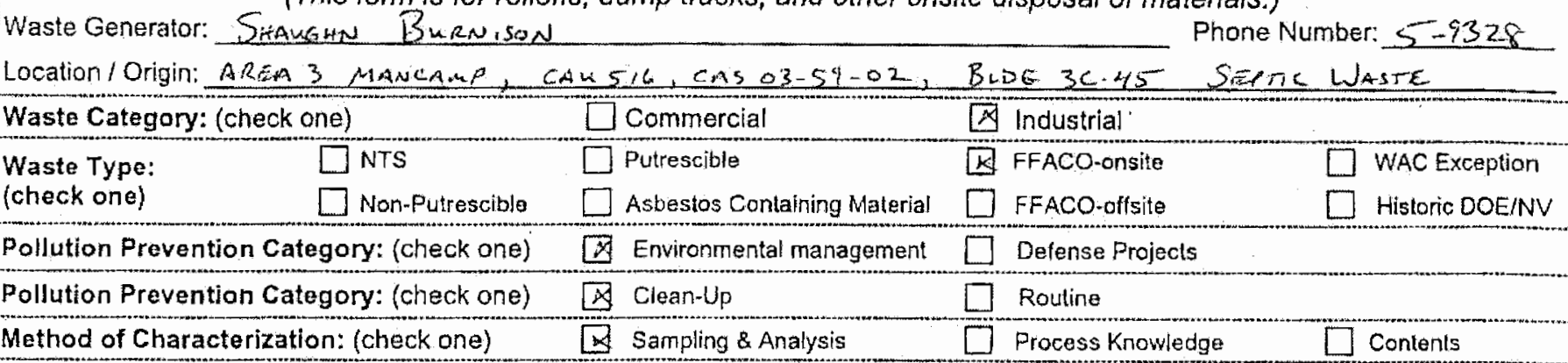

Prohibited Waste Radioactive waste; RCRA waste; Hazardous waste; Free liquids, PCBs above TSCA regulatory levels-, and Medical at all three NTS landfills: wastes (needles, sharps, bloody clothing).

Additional Prohibited Waste Sewage Sludge; Animal carcasses-, Wet garbage (food waste); and Friable asbeslos at the Area 9 U10c Landfill:

\section{REQUIRED: WASTE CONTENTS ALLOWABLE WASTES}

Check all allowable wastes that are contained within this load:

NOTE: Waste disposed al the Area 6 Hydrocarbon Landfill must have come into conlact with petroleum hydrocarbons or coolants such as: gasoline (no benzene, lead); jet fuel; diesel fuel; lubrican's and hydraulics; kerosene; asphaltic petroleum hydrocarbon; and ethyiene glycol

Acceptable waste at any NTS landfill: $\square$ Paper $\square$ Rocks / unaltered geologic materials $\square$ Empty containers
$\square$ Asphalt
$\square$ Metal
$\square$ Wood
Soil
$\square$ Rubber (excluding tires)
Demolition debris
Plastic
$\square$ Wire
$\square$ Cable
$\square$ Cloth
Insulation (non-Asbestosform)
[X Cement \& concrete

Manufactured items: (swamp coolers, furniture, rugs, carpet, electronic components, PPE, etc.)

Additional waste accepted at the Area 23 Mercury Landfill: $\square$ Office waste $\square$ Food Waste $\square$ Animal Carcasses

Asbestos: $\square$ Friable $\square$ Non-Friable (contact SWO if regulated load) Quantity:

Additional waste accepted at the Area 9 U10c Landfill:
$\square$ Non-friable asbestos
$\square$ Drained automobiles and military vehicles
Light ballasts (contact SWO)
$\square$ Drained fuel filters (gas \& diesel)
Solid fractions from sand/oll/water separators
$\square$ Hydrocarbons (contact SWO)
Deconned Underground and Above Ground Tanks

Additional waste accepted at the Area 6 Hydrocarbon Landfill:
$[x$ Septic sludge $\square$ Rags
$\square$ Drained fuel fiters (gas $\&$ diesel)
Crushed non-terne plated oil filters
$\square$ Plants Lo Dest, sorisirico
Sludge from sand/oil/water separators
D PCBs below 50 parts per million

REQUIRED: WASTE GEN
Initials: $S B$ (If initialed, no radiological clearance is necessary.)

The above mentioned waste was generated outside of a Controlled Waste Managamant Area /CWMal and fo tha haet at mu, krowledge, does not contain radiological materials.

To the best of my knowledge, the waste described above contains only those ma site. I have verlfied this through the waste characterization method identified abo prohibited and allowable waste items.

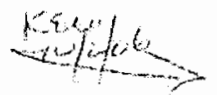

Print Name: SHAWGHN Burnison

Signature:

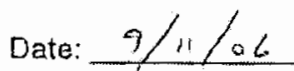

Radiological Survey Release for Waste Disposal RCT Initials

Thls containerlload meets the criterla for no Thls contalnerlload meets the criterlo for Cis This containerlload meets the criteria for Radcon Manual Tob́le 4.2 release Ilmits. Thls container/lod is exempt from survey due to propess knowledge and origin. SIGNATURE: DATE: $Q 0 \cdot 3 \cdot Q$

Note: Food waste, office trash and/or animal carcasses are considered not to contain added radioactivity, and therefore do not require a radiological clearance.

\section{SWO USE ONLY}

Load Weight (net from scale or estimate): $22^{\prime} A_{0}, 00$ Signature of Certifier: 


Waste Category: (check one) $\square$ commercial $\square$, $\square$ industrial

Waste Type: $\square$ NTS $\square$ Putrescible $\square$ FFACO-Onsile $\square$ WAC Exception

(check one)

$\square$ Non-Putrescible

$\square$ Asbestos Containing Material

$\square$ FFACO-olfsite Hisioric DOENN

Pollution Prevention Category: (check one)

Pollution Prevention Category: (check one) Method of Characterization: (check one)

A Environmental management

$\triangle$ Clean-Up

Q Sampling 8 Analysis

$\square$ Defense Projects

Prohibited Waste

Radioactive waste; RCRA waste; Hazardous waste; Free liquids, PCBs above TSCA regulatory levels-, and Medical at all three NTS landfills:

wastes (needles, sharps, bloody clothing).

Additional Prohibited Waste Sewage Sludge; Animal carcasses-, Wet garbage.(food waste); and Friablo asbestos at the Area 9 U10c Landfill:

\section{REQUIRED: WASTE CONTENTS ALLOWABLE WASTES}

Check all allowable wastes that are contained within this load:

NOTE: Waste disposed at the Area 6 Hydrocarbon Landfill must have come inlo contact with petroleum hydrocarbons or coolants such as: gasoline (ro benzene, lead); jet fuel; diesel fuel; lubricants and hydraulics; kerosene; asphattic petroleum hydrocarbon; and ethylene glycol.
Acceptable waste at any NTS landfill:
$\square$ Asphalt
$\square$ Metal
$\square$ Wood
$\square$ Paper
[A] Rocks / unaltered geologic materials
$\square$ Rubber (excluding tires)
$\square$. Empty containers
(E) Plastic
$\square$ Wire
$\square$ Cable $\square$ Cloth
$\square$ Demolition debris
[2. Cement \& concrete

$\square$ Insulation (non-Asbestosform)

$\square$ Manufactured items: (swamp coolers, fumiture, rugs, carpet; electronic components, PPE, etc.)

Additional waste accepted at the Area 23 Mercury Landfill: $\square$ Office Waste $\square$ Food Waste $\square$ Animal Carcasses

$\square$ Asbestos: $\square$ Friable $\square$ Non-Friable (contact SWO if regulated load) Quantity:

Additional waste accepted at the Area 9 U10c Landfill:
$\square$ Non-friable asbestos
$\square$ Drained automobiles and military vehicles
Light baliasts (contact SWO)
Drained fuel filters (gas \& diesel)
Solid fractions from sand/oil/water separators
Hydrocarbons (contact SWO)
Deconned Underground and Above Ground
Tanks

Additional waste accepted at the Area 6 Hydrocarbon Landfill:

$\begin{array}{lll}\square \text { septic sludge } \square \text { Rags } & \square \text {. Drained fuel filters (gas \& diesel) } & \square \text { Crushed non-terne plated oil filters } \\ \square \text { plants } & \square \text { sludge from sand/ollwater separators } & \square \text { PCBs below } 50 \text { parts per million }\end{array}$

Initials

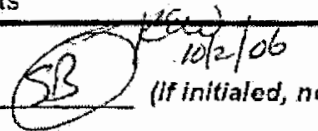

REQUIRED: WASTE GENERATOR SIGNATURE

The above mentloned waste was generated outside of a Controlled Waste Manageman knowledge, does not contain radiological materlais.

To the best of my knowledge, the waste described above contains only those mat site. I have verified this through the waste characterization method identified abou prohibited and allowable waste items.

Print Name: SHAwGitas Burneson

Signature:__._. Date: $9 / 27 / 04$

Radiological Survey Release for Waste Disposal RCT Initials

This container/load meets the criteria for no

This container/load meets the criteria for

Cw This contalnerlload meets the criteria for Radcon Manual Table 4.2 release limits. This containerlogt is exompt from survey due to processs browledge and origin.

SIGNATURE: DATE:, $2+06$

Note: Food waste, ofice trash and/or animal carcasses are considered not to contain added radioactivity, and therefore do not require a radiological clearance.

\section{SWO USE ONLY}




\section{Bechtel Nevada NTS Landfill Load Verification

\author{
(Waste definitions are avallable on page 2)
}

SWO USE (Circle One Area) AREA $\quad 23,(6) .9 \%$ LANDFILL

For waste characterization, approval, andlor assistance, contact Solid Waste Operation (SWO) at 5-7898.

REQUIRED: WASTE GENERATOR INFORMATION

(This form is for rolloffs, dump trucks, and other onsite disposal of materials.)

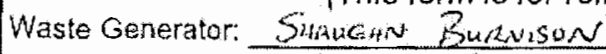

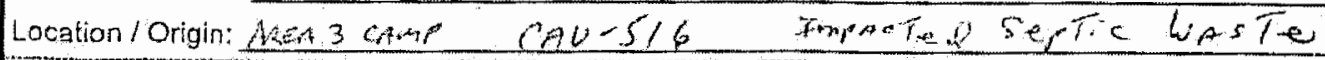

Waste Category: (check one) $\square$ Commercial D Industrial

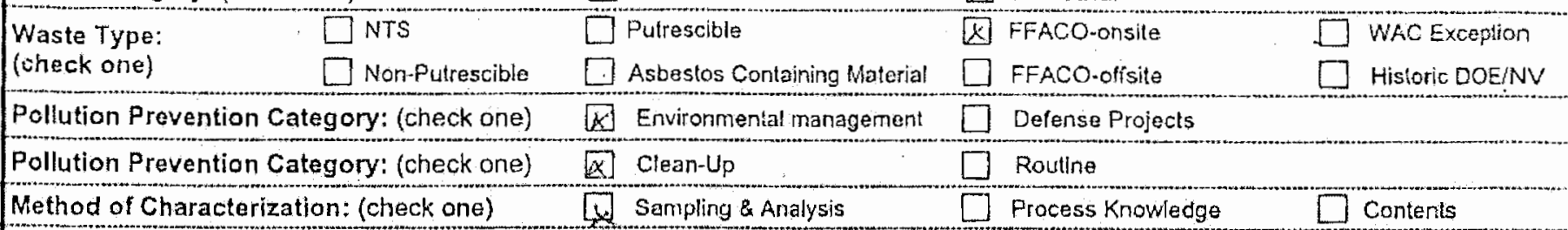

Prohibited Waste Radioactive waste; RCRA waste; Hazardous waste; Free liquids, PCBs above TSCA regulatory levels-, and Medical

at all three NTS landfills: wastes (needles, sharps, bloody clothing).

Additional Prohibited Waste Sewage Sludge: Animal carcasses-, Wet garbage (food waste); and Friable asbestos at the Area 9 U10c Landfill:

\section{REQUIRED: WASTE CONTENTS ALLOWABLE WASTES}

Check all allowable wastes that are contained within this load:

NOTE: Wasto disposed at the Area 6 Hydrocarbon Landfill must have come into contact with petroleum hydrocarbons or coolants such as: gasoline (no benzene, lead) jet fuel; diesel fuel; lubricants and hydraulics; kerosene; asphaltic petroleum hydrocarbon; and ethylene glycol.

Acceptable waste at any NTS landfill: $\square$ Paper $\quad$ Q Rocks/unaltered geologic materials $\square$. Empty containers
T Asphalt
[Metal
$\square$ Wood
$\triangle$ Soil
$\square$ Rubber (excluding tires).
[E] Pastic
$\square$ Wire
$\square$ Cable $\square$ Cloth
[] Insulation (non-Asbestosform)
[] Demolition debris
\& Cement \& concrete

Divanuiactured items: (swamp coolers, furnilure, rugs, carpet, elzctronic components, PPE, etc.)

Additional waste accepted at the Area 23 Mercury Landfill: $\square$ Office waste [] Food Waste $\square$ Animal Carcasses

$\square$ Asbestos: $\square$ Friable $\square$ Non-Friable (contact SWO if regulated load) Quantity:

Additional waste accepted at the Area 9 U10 c Landfill:
$\square$ Non-friable asbestos
$\square$ Drained automobiles and military vehicles
Solid fractions from send/oil/water separators
[L Light ballasts (contact SWO)
Drained fuel filters (gas \& diesel)
[] Deconned Underground and Above Ground
Hydrocarbons (contact SWO) Tanks

Additional wasto accepted at the Area 6 Hydrocarbon Landfill:

\begin{tabular}{ll}
$\square$ septic sludge $\square$ Rags & $\square$ Drained fuel filters (gas \& diesel) \\
$\square$ Plants & $\square$ sludge from sand/oil/water separators $\square$ Crushed non-terne plated oil filters \\
\hline Initials: 53 & $\square$ REQURED: WASTE GENERATOR SIGNATURE
\end{tabular}

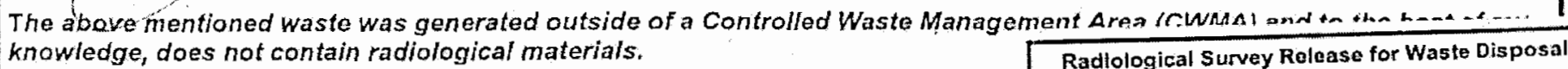

To the best of my knowledge, the waste described above contains only those mat site. I have verified this through the waste characterization method identified aboi prohibited and allowable waste items.

Radlological Survey Release for Waste Disposal
RCT Initlals This container/load meets the criteria for (a) Thls containarlload meets the criteria for Radcon Manual Table 4.2 release limits. This containerload is exempt from survey due to process knowledge and origin.

Print Name: Shatughe Bunnison! Signature: Date: $9 / 23 / 06$ DATE: 20.20 SIGNATURE: BN.DE46 (10105)

Note: Food waste, office trash and/or animal carcasses are considered not to contain added radioactivity, and therefore do not require a radiological clearance. 


\section{Bechtel Nevada NTS Landfill Load Verification}

(Waste definitlons are avallable on page 2)

SWO USE (Circle One Area) AREA $23 \quad(6) ; 9$ LANDFILL

For waste characterization, approval, andlor assistance, contact Solid Waste Operation (SWO) at 5-7898.

\section{REQUIRED: WASTE GENERATOR INFORMATION}

(This form is for rolloffs, dump trucks, and other onsite disposal of materials.)

Waste Generator: Sutaueste Burnison Phone Number: $5-9328$

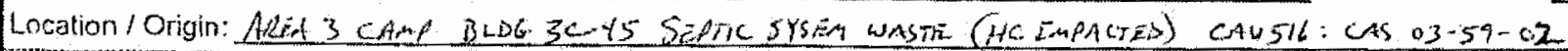

\begin{tabular}{|c|c|c|c|}
\hline Waste Category: (check one) & Commercial & $\triangle$ Industrial & \\
\hline \multirow{2}{*}{$\begin{array}{l}\text { Waste Type: } \\
\text { (check one) }\end{array}$} & $\square$ Putrescible & FFACO-onsite & [I WAC Exception \\
\hline & [ Asbestos Containing Material & [] FFACO-offsite & rlistoric DCEINV \\
\hline Pollution Prevention Category: (Check one) & 2 Clean-Up & Routine & \\
\hline Method of Characterization: (check one). & D Sampling \& Analysis & Procass Knowledge & Contents \\
\hline
\end{tabular}

Prohibited Waste Radioactive waste; RCRA waste; Hazardous waste; free liquids, PCBs above TSCA regulalory levels-, and Medical at all three NTS landfills: wastes (needles, sharps, bloody clothing).

Additional Prohibited Waste Sewage Sludge; Animal carcasses, Wel garbage (food Waste); and Friable asbestos at the Area 9 U10c Landfjll:

\section{REQUIRED: WASTE CONTENTS ALLOWABLE WASTES \\ Check all allowable wastes that are contained within this load:}

NOTE: Waste disposed at the Area 6 Hydrocartion Landfill must have come into contact with petroleum hydrocarbons or coolants such as: gasoline (no benzene, lead); jel fuel; diesel fuel; lubricants and hydraulics; kerosene; asphaltic petrule uri hydrocarbon; and ethylene glycol.

Acceptable waste at any NTS landfill: $\square$ Paper $\square$ Rocks / unaltered geologic materials $\square$ Empty containers
$\square$ Asphatt
$\square$ Metal
$\square$ Wood
[t] Soll
$\square$ Rubber (excluding tires)
[] Demolition debris
E) Plastic
$\square$ Wire
Cable $\square$ Cloth
[ Insulation (non-Asbestosforn)
[x] Cement \& concrete

[Wanuiactured items: (swarnp cooiers, rurniture, rugs, carpet, electronic components, PPE, elc.)

Additional waste arcepted at the Area 23 Mercury Landfill: $\square$ Office waste $\square$ Food Waste $\square$ Arimal Carcasses

[.] Asóstos: $\square$ Friable $\square$ Non-Friable (contact $S$ wo if regulated load) Quantity:

Additional waste accepted at the Area 9 U10c Landfill:
[-] Non-friable asbestos
Drained automobiles and military vehicles
Solid fractions from sand/oil/water separators
1] Light bellasts (contact SwO)
Drained fuel filters (gas \& diesel)
Deconned Underground and Above Ground
[ Hydrocaroons (contact SWO) Tanks
Additional waste accepted at the Area 6 Hydrocarbon Landfill:
U Septic sludge $\square$ Rags
$\square$ Drained fuel filters (gas \& diesel)
Crushed non-terne plated oil filters
Q Plants
Sludge from sand/oil/water separators
PCBs below 50 parts per million

initials $\left(\frac{S O}{2}\right.$ (If initialed, no radiological clearance is necessary.)

The above mentioned wasto was generated outside of a Controlled Waste Managemont 4 ros inWhaA sond fn the host nim.

knowledge, does not contaln radiological materials.

To the best of my knowledge, the waste described above contains only those mat site. I have verified this through the waste characterization method identified aboi prohibited and allowable waste items.

Radiologica! Survey Rolease for Waste Disposal ReT Initials

This contalnerlload meets the criteria for no added man-made radioactive material

S This container/load meets the criteria for Radcon Manual Tablo-32.2 release limits. This containetfoad is exempt from survey due to prgcosy frowledge and origin.

Print Name: Stauctin Buzvison

Signature. Date: $4 \cdot 28-2 \%$

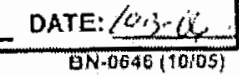

Note: Food waste, office trash andior animal carcasses are considered not to contain added radioactivity, and therefore do not require a radiological clearance. 


\section{Bechtel Nevada NTS Landfill Load Verification \\ (Waste definitions are avallable on page 2)

SWO USE (Circle One Area) AREA
For waste characterization, approval, andlor assistance, contact Solid Waste Operation (SWO) at 5.7898.

For waste characterization, approval, andlor assistance, contact Solid Waste Operation (SWO) at 5-7898.

REQUIRED: WASTE GENERATOR INFORMATION

(This form is for rolloffs, dump trucks, and other onsite disposal of materials.)

Waste Generator: H, ElOSD

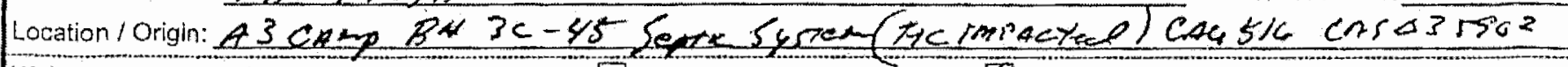

Waste Category: (check one)

Waste Type:

(check one)

$\square$ NTS

$\square$ Commercial

8 Industrial

$\square$ Putrescible

¿ FFACO-onsite

WAC Exception

Pollution Prevention Category: (check one)

[] Asbestos Conlaining Material

$\square$ FFACO-offsite

Historic DOE/NV

Pollution Prevention Category: (check one)

Method of Characterization: (check one)

$\forall$ Environmental management

$\square$ Defense Projects

$\triangle$ Clean-Up

(x) Sampling \& Analysis

$\square$ Routine

Prohibited Waste Radioactive waste; RCRA waste; Hazardous waste; Free liquids, PCBs above TSCA reguiatory levels-, and Medical at all three NTS landfills: $\quad$ wastes (needles, sharps, bloody clothing).

Additional Prohibited Waste Sewage Sludge: Animal carcasses-, Wet garbage (food waste); and Friable asbeslos at the Area 9 U10c Landfill:

\section{REQUIRED: WASTE CONTENTS ALLOWABLE WASTES}

Check all allowable wastes that are contained within this load:

NOTE: Wasle disposed at the Area 6 Hydrocarbon Landfill must have come into contacl with petroleum hydrocarbons or coolants such as: gasoline (no benzene, lead); jet fuel; diesel fuel; lubricants and hydraulics; kerosene: asphaltic petroleum hydrocarbon; and ethylene glycol.

Acceptable waste at any NTS landfill: $\square$ Paper $\square$ Rocks / unaltered geologic materials
$\square$ Asphalt
$\square$ Meta!
$\square$ Wood
[X] Soil :
$\square$ Cable
[] Cloth
$\square$ Rubber (excluding itres)
$\square$ Insulation (non-Asbestosform)
C) Plastic
$\square$ Wire

$\square$ Empty containers

Costers firnitur

electronic components, PPE, efc.)

Additional waste accepted at the Area 23 Mercury Landfill: $\square$ Office waste $\square$ Food Waste $\square$ Animal Carcasses

$\square$ Asbestos: $\square$ Friable $\square$ Non-Friable (conlact $S$ WO if regulated load) Quantity:

Additional waste accepted at the Area 9 U10c Landfill:
D Non-friable asbestos
$\square$ Drained automobiles and military vehicles
Solid fractions from sand/oil/water separators
$\square$ Light ballasts (contact SWO)
$\square$ Drained fuel filters (gas \& diesel)
Deconned Underground and Above Ground Tanks
$\square$ Hydrocarbons (contact SwO)

Additional waste accepted at the Area 6 Hydrocarbon Landfill:
$\square$ septic siudge $\square$ Rags
$\square$ Drained fuel filters (gas $\&$ diesel)
Crushed mon-ierne plated oil filters
$\square$ Plants
$\square$ Sludge from sand/oil/water separators
$\square$ PCBs below 50 parts per million

Initials: REQUIRED: WASTE GENERATOR SIGNATURE

The abov

(- If initialed, no radiological clearance is necessary.)

The abovementioned waste was generated outside of a Controlled Waste Manage knowledge, does not contain radiological materials.

To the best of my know/edge, the waste described above contains only thase mat site. I have verified this through the waste characterization method identified abov prohibited and allowable waste iterns.

Print Name: HoL L/OSO

Signature:
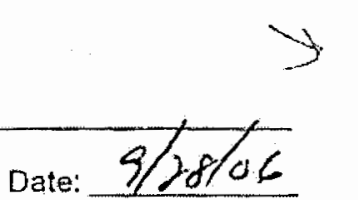

Note: Food waste, office trash andior animal carcasses are considered not to contain added radioactivity, and therefore do not require a radiological clearance.

\section{SWO USE ONLY}

Load Weight (net from scale or estimate) $=-20,52$

Signature of Certifier.
Radiologlcal Survey Release for Waste Disposal RCT Initials

This containerfload meets the criteria for no added man-mado radiloactive material

This containorlload meots the criterla for Radicon Manual Tabre 4.2 release limits. This contalndrllogl is exempt from survey due to procofss, hrowledge and origin.

SIGNATURE: DATE: 10.304 


\section{Bechtel Nevada NTS Landfill Load Verification}

(Waste definitions are availabje on page 2)

SWO USE (Circle One Area) AREA 23,6 LANDFILL

For waste characterization, approval, andlor assistance, contact Solid Waste Operation (SWO) at 5-7898.

REQUIRED: WASTE GENERATOR INFORMATION

(This form is for rolloffs, dump trucks, and other onsite disposal of materials.)

Waste Generator: $M, Z$ L Z 200

Phone Number: $\frac{5-2<13}{44^{2}}$

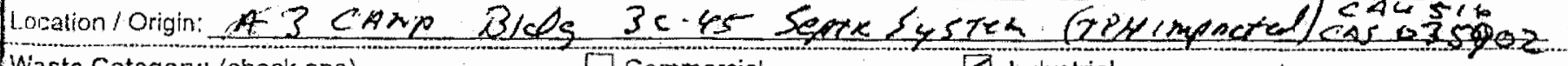

Waste Category: (check one)

Waste Type: $\square$ NTS

(check one) $\square$ Nan-Putrescible

$\begin{array}{ll}\square \text { Commercial } & \square \text { Industrial } \\ \square \text { Putrescible } & \triangle \text { FFACO-onsite } \\ \square \text { Asbestos Conlaining Material } \square \text { FFACO-offsite }\end{array}$

WAC Exception

Poliution Prevention Category: (check one) $Q$ Environmental management $\square$ Defense Projects

Pollution Prevention Category: (check one) $\quad \square$ Clean-Up Routine

Method of Characterization: (check one) Q Lampling \& Analysis $\square$ Process Knowledge $\square]$ Contents

Prohibited Waste Radioactive waste; RCRA waste; Hazardous waste; Free liquids, PCBs above TSCA regulatory levels-, and wedical at all three NTS landfills: wastes (needles; sharps, bloody clothing).

Additional Prohibited Waste Sewage Sludge; Animal carcasses. Wet garbegs (food waste); and Friable asbestos at the Area 9 U10c Landfill:

\section{REQUIRED: WASTE CONTENTS ALLOWABLE WASTES}

Check all allowable wastes that are contained within this load:

NOTE: Waste disposed al the Area 6 Hydrocarbon Landfill must heve come into contact with petroleum hydrocarbons or coolants such as: gasoline (no benzene, lead); jet fuel; diesel fuel; lubricants and hydraulics; kerosene; asphaltic petroleum bydrocarbon; and ethylene glyco:

Acceptable waste at any NTS landfili: $\square$ Paper $\square$ Rocks/unaltered geologic materials $\square$ Empty containers
Asphalt
$\square$ Metal
$\square$ Wood
Q
$\square$ Rubber (excluding tires)
$\square$ Demolition debis
D Plastic
[ Wire
$\square$ Cable $\square$ cloth
$\square$ Insulation (non-Asbestosform)
4 Cement \& concreie

[ Manufactured items: (swamp coolers, furniture, rugs, carpet, electronir components. PPE, etc.)

Additional waste accepted at the Area 22 Mercury Landfill: $\square$ Office waste $[$ Food Waste $\square$ Animal Carcasses

[] Asbestos: $\square$ Friable $\square$ Non-Friable (contact Swo if regulated load) Ouantity"

Additional waste accepted at the Area 9 U10c Landfill:
i] Non friable asbestos
$\square$ Drained automobiles and military vehicles
Solid fractions from sandioll/water separators
[] Light ballasts (contacl SWO)
$\square$ Drained fuel fifters (gas \& diesel)
$\square$ Deconned Underground and Above Ground
Jydrocarbons (contact SWO)
[] Tanks

Additional waste accepted at the Area 6 Hydrocarbon Landfill:
$\square$ Septic sludge $\square$ Rags
$\square$ Drained fuel filters (gas \& diesel)
Crushed non-terne plated oil filters
$\square$ Plants
$\square$ sludge from sand/oil/water separalors
$\square$ PCBs below 50 parts per million

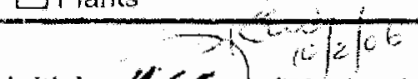

Initials: LSS (if Initialed, no radiological clearance is necessary.)

The above mentioned waste was generated outside of a Controlled Waste Management Area (CWMA) and to the best of my knowledge, does not contain radiological materials.

To the best of my knowledge, the waste described above contains only those matt site. I have verified this through the waste characterization method identlfied abov prohibited and allowable waste items.

Radiological Survey Release for Waste Disposal RCT Initials

Thls containerfload mests the eriterla far no

- added man-mado radioactive material

(1) This contalner/load meets the criteria for Radcon Manual Table $4 / 2$ release IImits. This containerflogo is texempt from survey

Print Name: $4,6, \quad$ To, $4 \%$

Signature. Date: $9 / 28 / 6 \mathrm{C}$ due to process kfoukedge and origin. SIGNATURE: $\Longrightarrow=$

Note: Food waste, office trash and/or animal carcasses are considered not to contain adueo raoloactivty, and therefore do not require a radiological clearance. 


\section{Bechtel Nevada NTS Landfill Load Verification \\ (Waste definitions are availabie on page 2)}

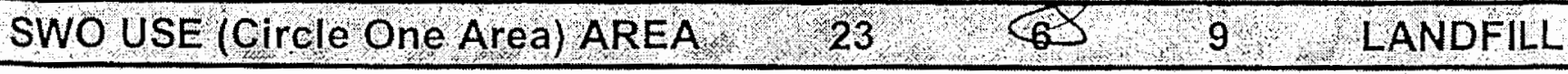

For waste characterization, approval, and/or assistance, contact Solid Waste Operation (SWO) at 5-7898.

\section{REQUIRED: WASTE GENERATOR INFORMATION}

(This form is for rolloffs, dump trucks, and other onsite disposal of materials.)

\begin{tabular}{|c|c|c|c|c|}
\hline \multicolumn{5}{|c|}{ 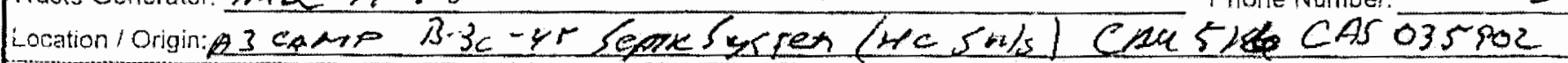 } \\
\hline \multicolumn{2}{|c|}{ Waste Category: (check one) } & $\square$ Commercial & Findusirial & \\
\hline \multirow{2}{*}{$\begin{array}{l}\text { Waste Type: } \\
\text { (check one) }\end{array}$} & $\square$ NTS & $\square$ Putrescible & {$[7$ FACO-onsite } & [] WAC Exception \\
\hline & $\square$ Non-Putrescible & $\square$ Asbestos Containing Material & $\square$ FFACO-offsite & $\square$ Historic DOEINV \\
\hline \multicolumn{2}{|c|}{ Pollution Prevention Category: (check one) } & 2 Environmental management & $\square$ Defense Projects & \\
\hline \multicolumn{2}{|c|}{ Pollution Prevention Category: (check one) } & $\notin$ Clean-Up & Routine & \\
\hline \multicolumn{2}{|c|}{ Method of Characterization: (check one) } & Q Sampling \& Analysis & 口 Process Knowledge & $\square$ Contents \\
\hline
\end{tabular}

Prohibited Waste Radioactive waste: RCRA waste; Hazardous waste; Froe liquids, PCBs above TSCA regulatory levels-, and Medical at all three NTS landfills: wastes (needles, sharps, bloody clothing).

Additional Prohibited Waste Sewgge Sludge: Animal carcasses-, Wet garbage (food waste), and Friable asbestos at the Area 9 U10c Landfill:

\section{REQUIRED: WASTE CONTENTS ALLOWABLE WASTES}

Check all allowable wastes that are contained within this load:

NOTE: Wasle disposed at the Area 6 Hydrocarbon Landfill must have come into conlact with petroleum hydrocarbons or coolants such as: gasoline (no benzene, lead); jel fuel; diesel fuel; lubricants and hydraulics; kerosene; asphaitic petroleum nydrocarbon; and elhylene glycol.

Acceptable waste at any NTS landfill: $\square$ Paper $\square$ Rocks / unaltered geologic materials $\square$ Empty containers
$\square$ Asphalt
$\square$ Melal
$\square$ Wood
B] Soll
$\square$ Rubber (excluding tires)
$\square$ Demolition debris
If Plastic
$\square$ Wire
$\square$ Cable $\square$ cloth
[I Insulation (non-Asbestosform)
D Cemen! \& conerete

[ Manufactured items: (swamp coolers, furniture, rugs, carpel, electronic components, PPE, etc.)

Additional waste accepted at the Area 23 Mercury Landfill: $\square$ office waste $\square$ Food Waste $\square$ Animal Carcasses

$\square$ Asbestos: $\square$ Friable $\square$ Non-Friable (contact SWO if regulated load) Quantity:

Additional waste accepted at the Area 9 U10c Landfill:
ENon-friable asbestos
$\square$ Drained automobiles and military vehicles
Solid fractions from sand/oil/water separators
I Light ballasts (contact SWO)
Drained fuel filters (gas \& diesel)
$\square$ Deconned Underground and Above Ground
$D$ Hydrocarbons (contact SWO)
Tanks

Additional waste accepted at the Area 6 Hydrocarbon Landfill:
$\square$ Septic sludge $\square$ Rags
$\square$ Drained fuel filters (gas \& diesel)
Crushed non-terne plated oil filters
$\square$ Plants a. 60.6
Sludge from sand/oil/water separators
PCBs below 50 parts per million
Initials

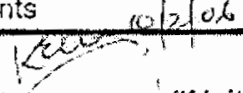
REQUIRED: WASTE GENERATOR SIGNATURE
(If initialed, no radiological clearance is necessary.)

The above mentioned waste was generated outside of a Controlled Waste Manage knowledge, does not contain radiological materials.

To the best of my knowledge, the waste described above contains onily those matk site. I have verifjed this through the waste characterization method identified abov prohibited and allowable waste items.

Print Name:

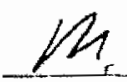

Signature:
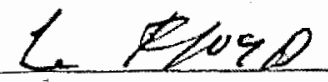

Note: Food waste, office trash andior an
require a radiological clearance.

SWO USE ONLY

Load Weight (net from scale or estimate) $/ f, \geq 12$ Signature of Certifier

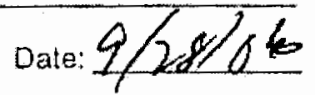

Radiological Survey Release for Waste Disposal RCT Inltials

This contalnerload meets the criteria for no added man-made radloactive material

(l) Thls containerlload meets the criteria for Radcon Manual Táfie 4.2 release limits. This containgerligad is exempt from survey duo to arodess knowledge and origin. SIGNATURE. DATE:/ $14-6$

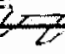

BN.D64G 


\section{Bechtel Nevada}

NTS Landfill Load Verification

(Waste definitions are available on page 2)

SWO USE (Circle One Area) AREA $23 \quad$ (6) 9 . LANDFILL

For waste characterization, approval, andlor assistance, contact Solid Waste Operation (SWO) at 5-7898.

REQUIRED: WASTE GENERATOR INFORMATION

(This form is for rolloffs, dump trucks, and other onsite disposal of materials.)

Waste Generator: Mh $\mathcal{L}_{\text {Eis }}$ Therm

Phone Number:

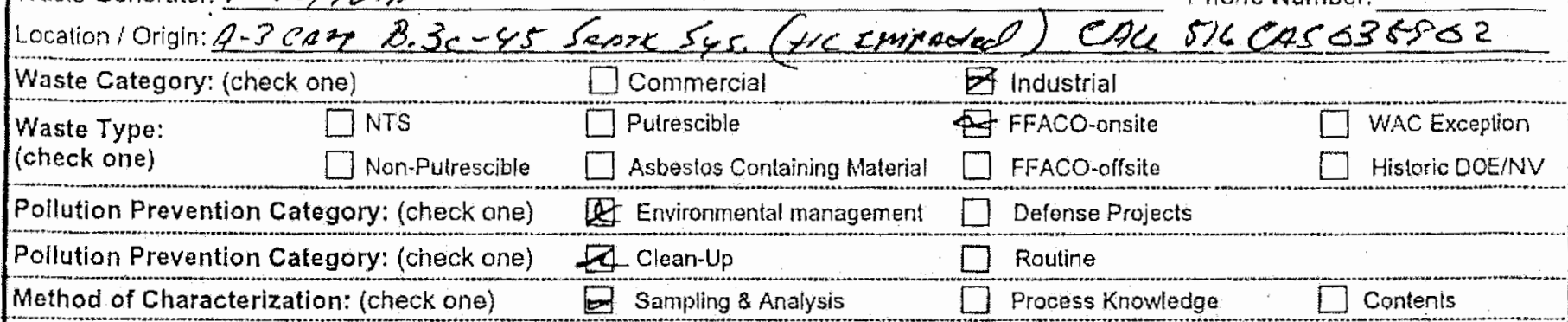

Method of Characterization: (check one) $\quad$ a Sampling \& Analysis $\square$ Process Knowledge $\square$ Contents

at all three NTS landfills: wastes (needles, sharps, bloody clothing).

Additional Prohibited Waste Sewage Sludge; Animal carcasses-, Wet garbage (food waste); and Friable asbestos

at the Area 9 U10c Landfill:

REQUIRED: WASTE CONTENTS ALLOWABLE WASTES
Check all allowable wastes that are contained within this load:

NOTE: Waste disposed at the Area 6 Hydrocarbon Landfill must have come inlo contact with petroleum hydrocarbons or coolants such as:
gasoline (no benzene, lead); jet fuel: diesel fuel; lubricants and hydraulics; Kerosene; asphattic pelroleum hydrocarbon; and elhylene glycol.
Acceptable waste at any NTS landfill:
$\square$ Paper
[Rocks / unaltered geologic materials
[] Emply containers
$\square$ Asphait $\square$ Metal $\square$ wood $\square$ soil
7fPlastic
[ Wire
D.] Cable
Cloth
$\square$ Rubber (excluding tires)
$\square$ insulation (non-Asbestosform)
Demolition debris
[3) Cement \& concrete

D Manufactured items: (swanp coolers, furniture, rugs, carpel, electronic components, PPE, etc.)

Additional waste accepted at the Area 23 Mercury Landfill: $\square$ Office waste $\square$ Food Waste $\square$ Animal Carcasses

[.] Asbestos: $\square$ Friable $\square$ Non-Friable (cuntact Swo if regulated load) Quantity:

Additional waste accepted at the Area 9 U10c Landfill:

$\begin{array}{ll}\square \text { Non-friable asbestos } & \square \text { Drained automobiles and military vehicles } \\ \square \text { Light ballasts (contact SWO) } \square \text { Drained fuel filters (gas \& diesel) } & \square \text { Deconned Underground and Above Ground } \\ \square \text { Hydrocarbons (contact SWO) } & \square \text { Tanks }\end{array}$

Additional waste accepted at the Area 6 Hydrocarbon Landfill:

\begin{tabular}{ll}
$\square$ Septic sludge $\square$ Rags & $\square$ Drained fuel filters (gas \& diesel) \\
$\square$ plants & $\square$ Sludge from sand/oil/water separators $\quad \square$ PCBshed non-terne plated oil filters \\
\hline REQUIRED: WASTE GENERATOR SIGNATURE & $\square 0$ parts per million
\end{tabular}

Initials: (If initialed, no radiological clearance is necessary.)

The above mentioned waste was generated outside of a Controlled Waste Management Area (CWMA) and to the best of my knowledge, does not contain radiological materials.

To the best of my knowledge, the waste described above contains only those mai site. I have verified this through the waste characterization method identified abo! prohibited and allowable waste items.

Print Name: 1 L L L L

Signature: fivis

Note: Food waste, office trash and/or animal carcasses aro considered not to contain added radioactivity, and therefore do not require a radiological clearance.

SWOUSE ONLY

Load Weight (net from scale or estimate) $/, /, 000$ signalure of certifier

Radiological Survey Release for Waste Disposal RCT Initlals

This containeriload moets the criteria for no

addod man-made radioactive material

$\mathrm{C} W$ This container/load meets the criteria for Radcon Manual Table 4.2 reloaso 1 imlts. This containeriload is exempt from survey due to protess knowledge and origin.

SIGNATURE: DATE: $\frac{1320}{\text { BN-0646(10\%5) }}$ 


\section{SWO USE (Circle One Area) AREA

For waste characterization, approval, andlor assistance, contact Solid Waste Operation (SWO) at 5-7898.

\section{REQUIRED: WASTE GENERATOR INFORMATION}

(This form is for rolloffs, dump trucks, and other onsite disposal of materials.)

Waste Generator: MiL ELOYO

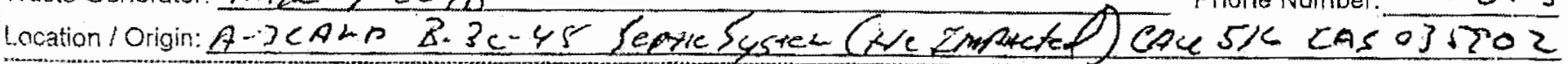

Waste Category: (check one)

Waste Type: $\quad$ LTS

$\square$ Commercial

$\square$ Putrescible

E. Industral

(check one)

$\square$ Non-Putrescible

$\square$ Asbestos Containing Material

2 FFACO-Onsile

WAC Exception

Pollution Prevention Category: (check one)

E- Environmental management

$\square$ FFACO-offsite

Historic DOE/NV

Pollution Prevention Category: (check one) Method of Characterization: (check one)

$\triangle$ Clean-Up

$\square$ Defense Projects

E) Sampling \& Aralysis

$\square$ Routine

\section{Prohibited Waste}

at all three NTS landfills:

$\square$ Process Knowledge

Contents

Additional Prohibited Waste Sewage Sludge; Animal carcasses., Wet garbage (food waste); and Friable asbestos at the Area 9 U10c Landfill:

\section{REQUIRED: WASTE CONTENTS ALLOWABLE WASTES}

Check all allowable wastes that are contained within this load:

NOTE; Waste disposed at the Area 6 Hydrocarbon Landfill must have come into contact with petroleum hydrocertions or coolants such as: gasoline (no benzene, lead): jel fuel; diesel fuel; lubricants and hydraulics; kerosene; asphallic petroleun hydrocarbon; and ethylene glyol
Acceptable waste at any NTS landfill:
[Asphat
DNetal
$\square$ Wood
$\square$ Paper
$\square$ Rocks / unaltered geologic materials
$\square$ Empty containers
E Piastic
[.] Wire
$\square$ Cable $\square$ Cloth
$\square$ Rubber (excluding tires)
$\square$ Insulation (non-Asbestosform)
$\square$ Demolition debris

L] Manufactured itens: (swarnp coolers, furniture, rugs, carpet, electronic components, PPE, etc.)

Additional waste accepted at the Area 23 Mercury Landfill: $\square$ Office waste $\square$ Food Waste $\square$ Animal Carcasses

I] Asbestos: $\square$ Friable $\square$ Non-Friable (contact SWO if regulated load) Quantity:

Addiclonal waste accepted at the Area 9 U10c Landfill:

$\square$ Non-frizble asbestos $\square$ Drained automobiles and military vehicles

Solid fractions from sand/oil/water separators

L Light ballasts (contact SWO)

D Drained fuel fitters (gas \& diesel)

Deconned Uncerground and Above Ground

1] Hydrocarbons (contact SWO)

Tanks

Additional waste accepted at the Area 6 Hydrocarbon Landfill:
$\square$ septic sludge $\square$ Rags
$\square$ Drained fuel filters (gas \& diesel)
$\square$ plan's
$\square$ Sludge from sandioil/water separators
Crushed non-terne plated oil fitters

REQUIRED: WASTE GENERATOR SIGNATURE

Initials:

(If inilialed, no radiological clearance is necessary.)

The above mentioned waste was generated outside of a Controlled Waste Manago knowledge, does not contain radiological materials.

To the best of my knowledge, the waste described above contains anly those ma site. I have verified this through the waste characterization method identified abo prohibited and allowable waste items.

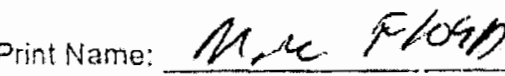

Signature:

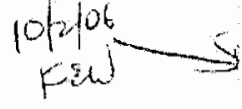

Date: $9 / 29 / 6 C$ Radiological Survey Relcase for Waste Disposal RCT Initials

This container/load meets the criterla for no added man-made radioactive materia!

(1) This contalnerlioad poets the criteria for Radcon Manual Tpffo 4.2 release limits. This container/lod is axampt from survoy due to process knowledge and origin.

\section{SIGNATURE} DATE: $0.3 .4 \%$ BN.0645:(10;05)

Note: Food waste, office trash andfor animal carcasses are considered not to contain added radioactivity, and therefore do not require a radiological clearance. 


\section{Bechtel Nevada NTS Landfill Load Verification \\ (Waste definitions are available on page 2)}

\section{SWO USE (Circle One Area) AREA 23 (6) 9 LANDFILL}

For waste characterization, approval, andlor assistance, contact Solid Waste Operation (SWO) at 5-7898.

\section{REQUIRED: WASTE GENERATOR INFORMATION}

(This form is for rolloffs, dump trucks, and other onsite disposal of materials.)

Waste Generator: MCL Efoyp

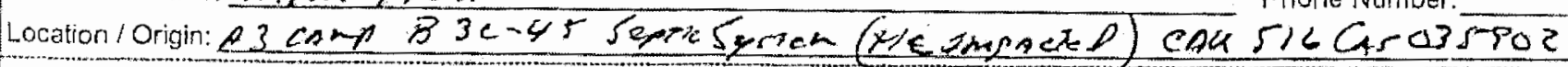

Waste Category: (check one) $\square$ commercial $\triangle$ Industrial

Waste Type: $\square$ NTS $\square$ Putrescible $\square$ FFACO-onsite $\square$ WAC Exception

(check one) $\square$ Non-Putroscible $\square$ Asbeslos Conlaining Malerial $\square$ FFACO-offsite $\square$ Historic DOE/NV

Pollution Prevention Category: (check one) $\not$ Environmental management $\square$ Defense Projects

Pollution Prevention Category: (check one) $\triangle$ Clean-Up $\square$ Routine

Melhod of Characterization: (check one) $\quad$ Sampling \& Analysis $\square$ Process Knowledge $\square$ Contenls

Prohibited Waste Radioactive waste; RCRA waste; Hazardous waste, Free liqulds, PCBs above TSCA regulatory levels-, and Medicai at all three NTS landfills: wastes (needles, sharps, bloody clothing).

Additional Prohibited Waste Sewage Sludge; Animal carcasses-, Wet garbage (food waste); and Friable asbestos at the Area 9 U10c Landfill:

\section{REQUIRED: WASTE CONTENTS ALLOWABLE WASTES}

Check all allowable wastes that are contained within this load:

NOTE: Waste disposed at the Area 6 Hydrocarbon Landfll must have come into conlact with petroleum hydrocarbons or coolants such as: gasoline (no benzene, lead); jel fuel; diesel fuel; lubricants and hydraulics; kerosene; asphaltic pelroleurn hydrocarbon; and elhylene glycol.

Acceptabli: waste at any NTS landfill: $\square$ Paper $\square$ Rocks / unaltered geologic materials $\square$ Empty containers

D. Asphali $\square$ Metal $\square$ Wood $\sum$ Soil $\square$ Rubber (excluding tires) $\square$ Demolition debris

W 45 Plastic $\square$ Wire $\square$ Cable $\square$ cloth $\square$ Insulation (non-Asbestosform)

I Vanufactured items: (swamp coolers, furniture, rugs, carpet, electronic components, PPE, elc.)

Additional waste accepted at the Area 23 Mercury Landfill: $\square$ Office waste $\square$ Food Waste $\square$ Animai Carcasses

$\square$ Asbestos: $\square$ Friable $\square$ Non-Friable (contact SWo if regulated load) Quantity:

Additional waste accepted at the Area 9 U10c Landfill:
ENon-friable asbeslos
$\square$ Drained automobiles and military vehicles
Solid fractions from sand/oil/water separators
Thight ballasts (contact SwO)
Drained fuel filters (gas \& diesel)
Deconned Underground and Above Ground
[] Hydrocarbons (contact SWO)
Tanks

Additional waste accepted at the Area 6 Hydrocarbon Landfil:
[ Septic sludge $\square$ Rags
$\square$ Drained fuel filters (gas \& diesel)
Crushed non-terne plated oil filters
DPlants
$\square$ Sludge from sand/oil/water separators:
PCBs below 50 parts per milition

initials:

\section{REQUIRED: WASTE GENERATOR SIGNATURE}

The above mentioned waste was generated outside of a Controlled Waste Manage knowledge, does not contain radiological materials.'

To the best of my knowledge, the waste described above contains only those mat site. I have verified this through the waste characterization method identified abo prohibited and allowable waste items.

rolo 106

Print Name: $\not h, 6 / 640$ (रit) $->$

Signature:

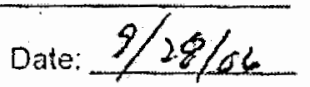

Radiological Survey Release for Waste Disposal RCT Initials

This containerlload meets the criteria for no added man-made radloactivo material This containerload meets the criterla for Radcon Manual Tole 4.2 release limits. This container/lag t's exempt from survey due to phocess kíwledge and origin. SIGNATURE: DATE: $10,2 \times 6$ BN.0.646 (10105)

Note: Food waste, office trash and/or animal carcasses are considered not to contain added radioactivity, and therefore do noi require a radiological clearance.

SWO USE ONLY:

Load Weight (net from scale or estimate) 


SWO USE (Circle One Area) AREA $23 \quad$ (6) 9 . 9 LANDFILL

For wasle characterization, approval, andlor assistance, contact Solid Waste Operation (SWO) at 5-7898.

\section{REQUIRED: WASTE GENERATOR INFORMATION}

(This form is for rolloffs, dump trucks, and other onsite disposal of materiais.)

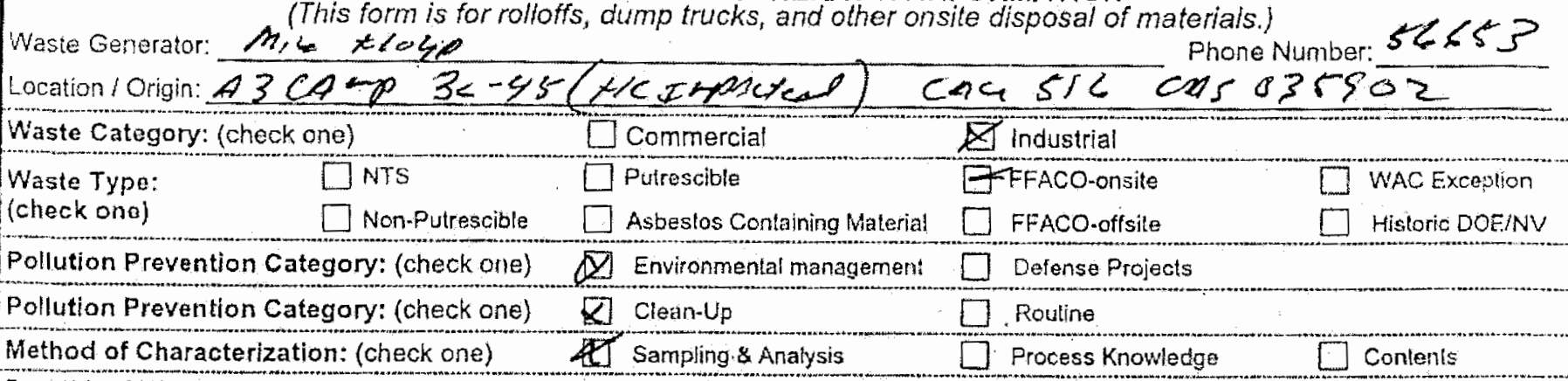

Prohibited Waste Radioactive waste; RCRA waste; Hazardous waste: Free liquids, PCBs above TSCA regulatory levels-, and Medical at all three NTS landfills: wastes (needles, sharps, bloody clothing).

Additional Prohibited Waste Sewage Sludge; Animal carcasses-, Wel garbage (food waste); and Friable asbesios at the Area 9 บ10c Landfill:

\section{REQUIRED: WASTE CONTENTS ALLOWABLE WASTES}

Check all allowable wastes that are contained within this load:

NOTE: Waste disposed at the Area 6 Hydrocarbon Landfill musl have come into contact with petroleum hydrocarbons or coolants such as: gzsoline (no benzene, lead); jel fuel; diesel fuel; lubricants and hydraulics; Kerosene; asphatic petroleum hydrocarbori: and ethylene glycol

Acceptable waste at any NTS landfill: $\square$ Paper $\square$ Rocks / unaltered geologic materials $\square$ Emply containers
[ Aspinal
$\square$ Metal
$\square$ Wood
IS Soil
$\square$ Rubber (excluding tires)
[] Demolition debris
[Q Plastic $\square$ Wire
$\square$ Cable $\square$ Cloth
$\square$ Insulation (non-Asbestosform)
3 Cement \& concrete

$\square$ Menufactured items: (swamp coolers, furniture, rugs, carpet, electronic components, PPE, etc.)

Additional waste accepted at the Area 23 Mercury Landfill: $\square$ Office waste $\square$ Food Waste $\square$ Animal Carcasses

$\square$ Asbestos: $\square$ Friabie $\square$ Non-Friable (contact SWO if regulated load) Quantity:

Additional waste accepted at the Area 9 U10c Landfif:
Unori-friable asbestos
$\square$ Drained automobiles and military vehicles
Solid fractions from sandiollwater separators
Light Dallasts (coritact SWO)
$\square$ Drained fuel fitters (gas \& diesel)
[ Deconned Underground and Above Ground
Hydrocarbons (contact SWO) Tanks

Additional waste accepted at the Area 6 Hydrocarbon Landfill:
$\square$ Septic sludge $\square$ Rags
$\square$ Drained fuel filters (gas \& diesel)
Crushed non-terne plated oil fitters
[Dlants
$\square$ sludge from sandloll/water separators
D PCBs below 50 parts per million

Initials:

REQUIRED: WASTE GENERATOR SIGNATURE

The above mentioned waste was generated outside of a Controlled Waste Management Area (CWMA) and to the best of my knowledge, does not contain radiolog/cal materials.

To the best of my knowledge, the waste described above contains only those mat site. I have verified this through the waste characterization method identified abov prohibited and allowable waste items.

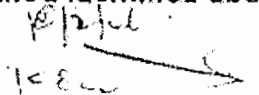

Print Name: $N_{2}, k$

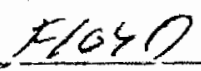

Signature:

Date:

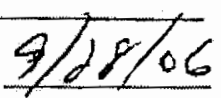

Radiological Survey Release for Waste Disposal RCT Inltials

This containeriload meots the criteria for no

added man-made radloactive material

cin This contalnerfload meats the criteria for Radcon Manual Tablo 4.2 release Jimits.

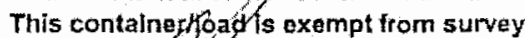
due in niocessk kowledge and origin.

SIGNATURE: DATE: 10.3

Note: Fcod waste, office trash andior animal carcasses are considered not to contain acded radioactivity, and therefore do not require a radiological clearance.

SWO USE ONLY

Load Weight (nel from scale of stimate) 14000 , signatire of Certifier: BN.0645(1005) 


\section{Bechtel Nevada NTS Landfill Load Verification}

(Waste definitions are avallable on page 2)

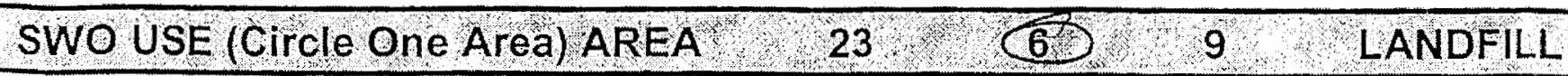

For waste characterization, approval, andlor assistance, contact Solid Waste Operation (SWO) at 5-7898.

REQUIRED; WASTE GENERATOR INFORMATION

(This form is for rolloffs, dump trucks, and other onsite disposal of materials.)

Waste Generator: $M 1, \angle$ EOS

Phone Number:

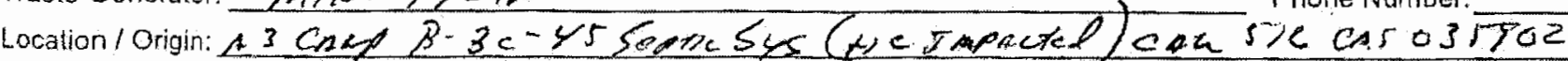

Waste Category: (check one) $\square$ Commercial $\square$ industrial

Waste Type: $\square$ NTS $\square$ Putrescible $\$$ GFACO-onsite WAC Exceplion

(check one) $\square$ Non-Putrescible $\square$ Asbestos Containing Material $\square$ FFACO-otfsite

Hisloric DOENV

Pollution Prevention Category: (check one) \&] Environmenlai management $\square$ Defense Projects

Pollution Prevention Category: (check one) \& Clean-Up. $\square$ Routina

Method of Characterization: (check one) $\quad Z$ Sampling \& Analysis $\square$ Process Knowledge $\square$ Contenls

Prohibited Waste Radioactive waste; RCRA waste; Hazardous waste; Freo liquids pCBs pbove TSCA regulatory levels-, and Medical at all three NTS landfills: wastes (needles, sharps, bloody clothing).

Additional Prohibited Waste Sewage Sludge; Animal carcasses-; Wet garbage (food waste); and Friable asbeslos at the Area 9 U10c Landfill:

REQUIRED: WASTE CONTENTS ALLOWABLE WASTES

Check all allowable wastes that are contained within this load:

NOTE; Wasle disposed at the Area 6 Hydrocarbon Landfill must have come into contacl with petroleum hydrocarbons or coolants such as: gasoline (no benzene, lead); jet fuel; diesel fuel; lubricants and hydraulics; kerosene; asphaltic petroleum hydrocarbon; and ethylene glycol.

Acceptable waste at any NTS landfill: $\square$ Paper $\square$ Rocks / unaltered geologic materials $\square$ Empty containers

GAsphall $\square$ Metal $\square$ Wood $\square$ soil $\square$ Rubber (excluding tires) Demolition debris

W. Plastic $\square$. Wire $\square$ Cable $\square$ cioth $\square$ Insulation (non-Asbestosform)

Cement \& concrete

Manufactured items: (swamp coolers, furniture, rugs, carpet, electronic components, PPE, etc.)

Additional waste accepted at the Area 23 Mercury Landfill: $\square$ office waste $\square$ Food Waste $\square$ Animal Carcasses

$\square$ Asbestos: $\square$ Friable $\square$ Non-Friable (contact SWO if regulated load) Quantity:

Additional waste accepted at the Area $910 \mathrm{c}$ Landfill:

$\square$ Non-friable asbestos $\quad \square$ Drained automobiles and military vehicles

Light ballasts (contact SWO) $\square$ Drained fuel filters (gas \& diesel)

Solid fractions from sandioilwater separators

Hydrocarbons (contact SWO)

Deconned Underground and Above Ground

Tanks

Additional waste accepted at the Area 6 Hydrocarbon Landfill:
$\square$ septic sludge $\square$ Rags
$\square$ Drained fuel filters (gas \& diesel)
Crushed non-terne plated oil filters
Plants
$\square$ Sludge from sand/oil/water separators
PCBs below 50 parts per million

Initials: REQUIRED: WASTE GENERATOR SIGNATURE

The above mentioned waste was generated outside of a Controlled Waste Managema

knowledge, does not contain radiological materials.

To the best of my knowledge, the waste described above contains only those mal site. I have verified this through the waste characterization method identified abo prohibited and allowable waste items. Kow

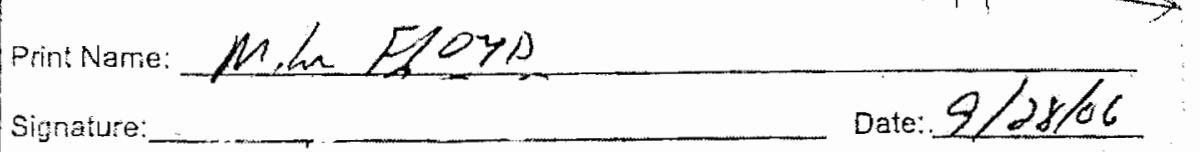

Radiological Survey Releaso for Waste Disposal RCT initlals

This containerlioad meets the criteria for no

This containerlload meets the criteria for Radcon Manual Tafle 4.2 release limits. This contalnerifoad is exempt from survey due to phacess krowlerige and origin.

SIGNATURE. DATE: $1032 \times$

Note: Food waste, oftice trash and/or animal carcasses are considered not to contain added radioactivity, and therefore do not require a radiological clearance.

SWO USE ONLY

Load Weight (net from scale or estimate) 


\section{Bechtel Nevada NTS Landfill Load Verification}

(Waste definitions are avallable on page 2)

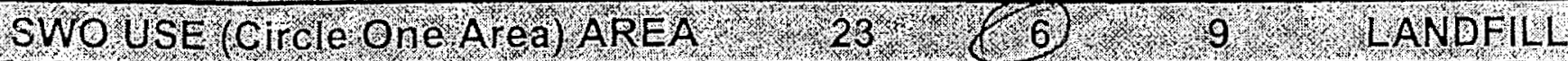

For waste characterization, approval, andlor assistance, contact Solid Waste Operation (SWO) at 5-7898.

REQUIRED: WASTE GENERATOR INFORMATION

Waste Generator: Sufuctis BuRvison

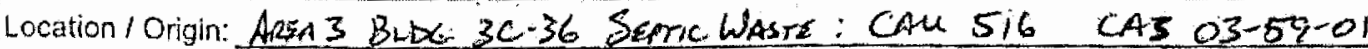

Waste Category: (check one) $\square$ Commercial $\square$ Industria

Waste Type: $\square$ NTS $\square$ Putrescible [R FFACO-onsito $\square$ WAC Exception

(check one)

Non-Pulrescible

$\square$ Asbestos Confaining Material

[] FFACO-offsite

[. Historic DOE/NV

Pollution Prevention Category: (check one) $\mathbb{E}$ Environmental management $\square$ Defense Projects

Pollution Prevention Category: (check one) $\quad$ Q Clean-Up Routine

Method of Characterization: (check one) $\quad \&$ Sampling \& Analysis $\quad \square$ Process Knowledge $\square$ Contents

Prohibited Waste

at all three NTS landfills:

Radioactive wasle; RCRA waste; Hazardous wasle; Free liquids, PCBs above TSCA regulatory levels-, and Medical wastes (needies, sharps, bloody clothing).

Additional Prohibited Waste Sewage Sludge; Animal carcasses, Wet garbage (food wasle); and Friablo asbeslos at the Area 9 U10c Landfill:

REQUIRED: WASTE CONTENTS ALLOWABLE WASTES

Check all aliowable wastes that are contained within this load.

NOTE: Waste disposad at the Area 6 Hyurocarbon Landfill must have come into contact with petroleum hydrocarbons or coolants such as gasoline (no benzena, lead); jel fuel; diesel luel; Jubricanis and hydraufics; kerosene; asphaltic petroleum hydrocarbon; and ethylene gycol
Acceptable waste at any NTS landfill:
EAsphalt $\square$ Metal $\square$ Wood $[$ S Soil
Dable
$\square$ Paper
¿ Rocks / unaltered geologic materials
[. Empty containers
Trlastic
$\square$ Wire
Cloth
$\square$ Rubber (excluding tires)
$\square$ Demolition debris
Gement \& concrete

Z Manufactured items: (swamp coolers, furniture, rigs, carpet, electronic components, PPE, etc.)

Additional waste accepted at the Area 23 Mercury Landfill: $\square$ Office waste $\square$ Food Waste $\square$ Animal Carcasses

I. Asbestos: $\square$ Friable $\square$ Non-Friable (contact 5 Wo if regulated load) Quantity:

Additional waste accepted at the Area 9 U10c Landfill:
$\square$ Non-friable asbestos
$\square$ Drained automobiles and military vehicles
Solid fractions from sand/oil/water separators
$\square$ Light ballasts (contact SwO)
Drained fuel filters (gas $\&$ diesel)
$\square$ Deconned Underground and Above Ground
$\square$ Hydrocarbons (contact SWO)
Tanks

Additional waste accepted at the Area 6 Hydrocarbon Landfill:
$\square$ Septic sludge $\square$ Rags
$\square$ Drained fuel filters (gas \& diesel)
Crushed non-terne plated oil filters
[J Plants
$\square$ Siudge from sand/oil/water separators
[ PCBs below 50 parts per million

Initials: $S B$ REQUIRED: WASTE GENERATOR SIGNATURE

The above mentioned waste was generated outside of a Controlled Waste Management Area (CWMA) and to the best of my knowledge, does not contain radiological materials.

To the best of my knowledge, the waste described above contains only those materials that are allowed for disposal at this site. I have verified this through the waste characterization method identified above and a review of the above-mentioned orohibited and allowable waste items.

rint Name: SHaugun Bucurson

signature

$$
\text { Date: } 10 / 3 / 26
$$

If applicable, place BN-0646, "Radiological Release Sticker" here. Onsite use only.

lote: Food waste, office trash andor animal carcasses are considered not to contain added radioactivity, and therefore do not require a radiological clearance. 


\section{Bechtel Nevada NTS Landfill Load Verification \\ (Waste definitions are available on page 2).

SWO USE (Gircle One Area) AREA 23 . 6 LANDFILL

For waste characterization, approval, andlor assistance, contact Solid Waste Operation (SWO) at 5-7898.

REQUIRED: WASTE GENERATOR INFORMATION

(This form is for rolloffs, dump trucks, and other onsite disposal of materials,)

Waste Generator: SHawgitn Bunetsont

Phone Number: $5-9328$

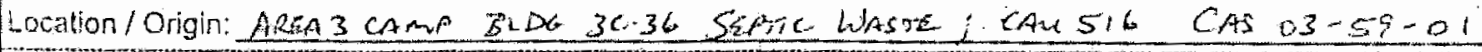

\begin{tabular}{|c|c|c|c|c|}
\hline \multicolumn{2}{|c|}{ Waste Category: (check one) } & Q commercial & (x) Industrial & \\
\hline \multirow{2}{*}{$\begin{array}{l}\text { Waste Type: } \\
\text { (check one) }\end{array}$} & $\square$ NTS & $\square$ Pulrescible & D. FFACO-onsite & $\square$ WAC Exception \\
\hline & $\square$ Non-Putréscible & $\square$ Asbestos Conlaining Material & $\square$ FFACO-oifsite & Historic DOEINV \\
\hline \multicolumn{2}{|c|}{ Pollution Prevention Category: (check one) } & Environmental management & [ Defense Projects & \\
\hline \multicolumn{2}{|c|}{ Pollution Prevention Category: (cheok one) } & D Clean-up & $\square$ Routine & \\
\hline \multicolumn{2}{|c|}{ We thod of Characterization: (check one) } & A Sampling \& Analysis & Process Knowledge & Contents. \\
\hline
\end{tabular}

Prohibited Waste Radioactive waste; RCRA waste; Hazardous wasle; Free liquids, PCBs above TSCA regulatory levels-, and Medical at all three NTS landfilis: Wastes (needles, sharps, bloddy clothing).

Additional Prohibited Waste Sewage Sludge: Animal carcasses-, Wal garbage (lood Waste); and Frable asbeslos at the Area 9 U10c Landfill:

\section{REQUIRED: WASTE CONTENTS ALLOWABLE WASTES}

Check all allowable wastes that are contained within this foad:

NOTE: Waste disposed at the Aroa 6 Hydrocarbon Landfil must have come into contacl with petroleum hydrocarbons or coolants such as: gasoline (no benzene, laad); jet fuel; diesel fuel: lubricants and hydraulics; Korosene; asphattic petroleum tydrocarbon; and ethylene glycol.

Acceptable waste at any NTS landfill: $\square$ Paper $\square$ Rocks / unaltered geologic materials
$\square$ Asphall
[Matal
$\square$ Wood
$\$$ Soil
$\square$ Rubber (excluding tires)
$\square$ Demolition debiis

$\square$ Plastic $\square$ Wire $\square$ Cable $\square$ Clath $\square$ insulation (non-Asbestosform)

$\square$ Plastic $\square$ Wire $\square$ Cable $\square$ Clath $\square$ insulation (non-Asbestosform)

Diastic $\square$ Wire $\square$ Cable $\square$ Cloth $\square$ Insulation (non-Asbestosform)

[. Emply containers

Additional waste accepted at the Area 23 Mercury Landfill: $\square$ Office waste [] Food Waste $\square$ Animal Carcasses

[ Asbsstos: $\square$ Friable $\square$ Non-Friable (contact SWO if regulated load) Quantity:

Additiomal waste accepted at the Area 9 U10c Landfill:
G Norrifiable asbestos
Drained aulomobiles and military vehicles
Solid fractions from sand/oil/water separators
Dight ballasts (contact SWO)
$\square$ Drained fuel filters (gas \& diesel)
[.] Hydrocarbons (contact SWO)
Deconned Underground and Above Ground

Additional waste accepted at the Area 6 Hydrocarbon Landfill:
[ Septic sludge $\square$ Rags
D Drained fuel filters (gas \& diesel)
Ilpiants
[D sludge from sand/oil/water soparators
Crushed non-terme plated oil filters REQUIRED: WASTE GENERATOR SIGNATURE

Iritials: $S R$ (If initialod, no radlological clearance is necessary.

The above mentioned waste was generated outside of a Controlled Waste Manarromant Aras (riWMAl anri to tha hacf af mi knowledge, does not contain radiological materiais.

To the best of my knowlodge, the waste described above contains only those $n$ site. I have verified this through the waste characterization mathod identified al rohibitod and allowable waste items.

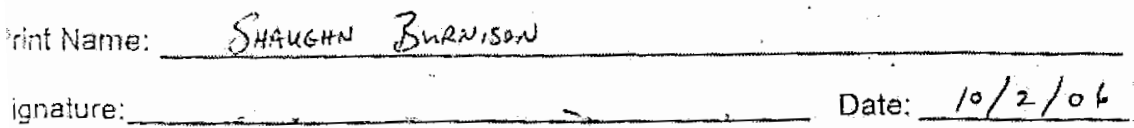

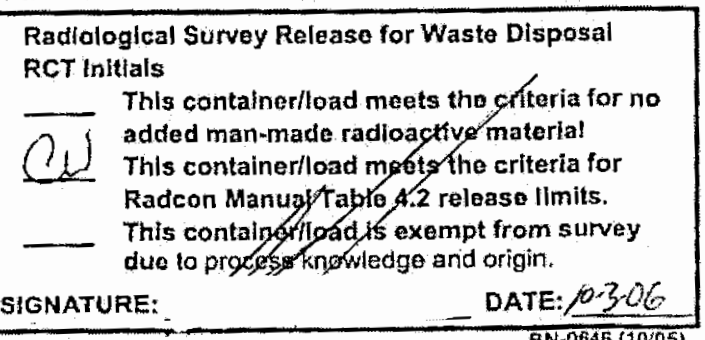

ote: Food waste, office trash andor animal carcasses are considered not to contain added radioactivity, and therefore do not require a rafliological clearance.

WOUSEONLY

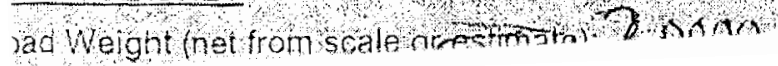




\section{Bechtel Nevada NTS Landfill Load Verification}

(Waste definitions are available on page 2)

SWO USE (Circle One Area) AREA $\quad 23,76)$ LANDFILL

For waste characterization, approval, andlor assistance, contact Solid Waste Operation (SWO) at 5-7898.

\section{REQUIRED: WASTE GENERATOR INFORMATION}

Waste Generator: Sthis form is for rollofin Burwison

(This form is for rolloffs, dump trucks, and other onsite disposal of materials.)

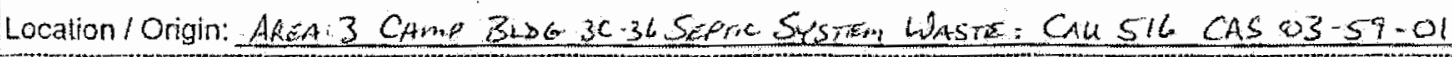

\begin{tabular}{|c|c|c|c|}
\hline Waste Category: (check one) & $\square$ commercial & Andustrial & \\
\hline \multirow{2}{*}{$\begin{array}{l}\text { Waste Type: } \\
\text { (check one) }\end{array}$} & $D$ Pulrescible & [1] FFACO-onsite & WAC Exception \\
\hline & [ Asbestos Conlaining Material & $\square$ FFACO-olfsite & $\square$ Historic DOENV \\
\hline Pollution Prevention Category: (check one) & $D$ Clean-Up & Rouline & \\
\hline Method of Characterization: (check one) & (1) Sampling \& Analysis & $\square$ Process Knowledge & Contents \\
\hline
\end{tabular}

Prohibited Waste Radioaclive wasle: RCRA waste; Hazardous waste; Freellquids, PCBs above TSCA regulatory levets-, and Medical

at all three NTS landfills: wastes (needles, sharps, bloody clothing).

Additional Prohibited Waste Sewage Sludge; Animal carcasses. Wel garbage (food waste); and Friable asbestos

at the Area 9 U10c Landfill:

REQUIRED: WASTE CONTENTS ALLOWABLE WASTES
Check all allowable wastes that are contained within this load:

NOTE: Waste disposed at the Area 6 Hydrocarbon Landifl must have come into contact with petroleum hydrocarbons or coolants such as: gasoline (no benzene, lead); jet fuel; diesel fuel; lubricants and bydraulics; kerosene; asphaltic pelroleum hydrocarbon; and ethylene giycol.

Acceptable waste at any NTS landfill: $\square$ Paper $\square$ Rocks / unaltered geologic materials $\square$ Emply containers
[ Asphalt
$\square$ Metal
$\square$ Wood
DAsoil
$\square$ Wire
$\square$ Cable
$\square$ Cloth
$\square$ Rubber (excluding tires)
['] Insulation (non-Asbestosform)
$\square$ Demolition debris
[X] Plastic

lers, furnifure, rugs, carpet, electronic components, PPE, etc.)

Additional waste accepted at the Area 23 Mercury Landfill: $\square$ Office waste $\square$ Food Waste $\square$ Arimal Carcasses

$\square$ Asbestos: $\square$ Friable $\square$ Non-Friable (contact $\$$ WO if regulated load) Quantity:

Additional waste accepted at the Area 9 U10c Landfill:
प Non-triable asbestos
$\square$ Drained automobiles and military vehlcles
$\square$ Light ballasts (contact SWO)
$\square$ Drained fuel filters (gas \& diesel)
Solid fractions from sand/oilwater separators
Hydrocarbons (contact SWO)
Deconned Underground and Above Ground Tanks

Additional waste accepted at the Area 6 Hydrocarbon Landfill:
$\square$ Septic sludge $\square$ Rags
$\square$ Drained fuel fitters (gas \& diesel)
$\square$ Sludge from sand/oil/water separators
Crushed non-terne plated ail filters
$\square$ Plants REQUIRED: WASTE GENERATOR SIGNATURE

Initials: (If initialed, no radiological ciearance is necessary.)

The above mentioned waste was generated outside of a Controlled Waste Manag knowledge, does not contain radiological materials.

To the best of my knowledge, the waste described above contains only those ma site. I have verlfied this through the waste characterization methodidentified abc prohibited and allowable waste items.

Print Name: SHAUE:N BuRN /SOA

Signature: Date: $10 / 2 / 06$ Radiological Survey Release for Waste Disposal RCT Initlals

_L Thls container/load moets the critorfa for no

Q I added man-made radioactive maferial

C1 This containerload meetsy be criteria for Radcon Manual Table 4 frelease limits. This containgrt 10 d d exempt from survey due to proesas kgowledge and origin. SIGNATURE: DATE: 10.346

Note: Food waste, office trash and/or animal carcasses are considered not to contain added radioactivity, and therefore do not require a radiological clearance. 


\section{SWO USE (Gircle One Area) AREA}

For waste characterization, approval, andior assistance, contact Solid Waste Operation (SWO) at 5-7898.

$$
\text { REQUIRED: WASTE GENERATOR INFORMATION }
$$

(This form is for rolloffs, dump trucks, and other onsite disposal of materials.)

Waste Generator: SHAiefen Bunnison

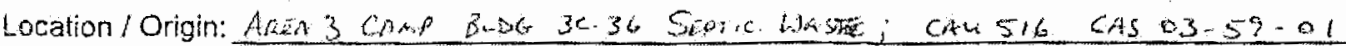

Waste Category: (check one)

Waste Type:

(check one)

$\square$ NTS

$\square$ Non-Putrescible

Pollution Prevention Category: (check one)

Pollution Prevention Category: (check one)

Method of Characterization: (check one)

[Q] Industrial

$\square$ Commercial

A FFACO-onsite

$\square$ Putrescible

[.] Asbestos Containing Material

[1] Environmental management

Q Clean-Up

(d) Sampling \& Analysis

[ FFACO-offsite

D Defense Projects

D Routine

Prohibited Waste

Radioactive wasfe; RCRA waste; Hazardo
wastes (needles, sharps, bloody clothing).

at all three NTS landilils:

Additional Prohibited Waste Sewage Sludge; Animal carcasses. Wel garbage (food waste); and Friable asbestos at the Area 9 U toc Landfill:

\section{REQUIRED: WASTE CONTENTS ALLOWABLE WASTES}

Check all allowable wastes that are contained within this load:

NOTE: Waste disposed at the Area 6 Hydrocarbon Landfill must have come into contact with petroleum hydrocarbons or coolants such as: gasoline (no benzene, lead); jet fuel; diesel fuel; lubricants and hydraulics; kerosene; asphaltic petroleum hydrocarbon; and ethylene glycol.

Acceptable waste at any NTS landfill: $\square$ Paper $\square$ Rocks/ unaltered geologic materiais $\square$ Empty containers

$\square$ Asphalt $\square$ Metal $\square$ Wood $\square$ Soil

$\square$ Plastic $\square$ Wire $\square$ Ćable $\square$ Cloth

$\square$ Rubber (excluding tires)

D Demolition debris

[] Insulation (non-Asbestosform)

$\square$ Cement \& concrete

$\square$ Manufactured items: (swamp coolers, furniture, rugs, carpet, electronic components, PPE, etc.)

Additional waste accepted at the Area 23 Mercury Landfill: $\square$ Office waste $\square$ Food Waste $\square$ Animal Carcasses

G Asbestos: $\square$ Friable $\square$ Non-Friable (contact SWO if regulated load) Quantity:

Additional waste accepted at the Area 9 U10c Landfill:

$\square$ Non-friable asbestos $\square$ Drained automobiles and military vehicles

$\square$ Light ballasts (contact Swo)

Drained fuel filters (gas \& diesel)

Solid fractions from sandlollwwater separators

7 Hydrocarbons (contact SWO)

$\square$ Deconned Underground and Above Ground

Additional waste accepted at the Area 6 Hydrocarbon Landfill:
$\square$ septic sludge $\square$ Rags
$\square$ Drained fuel filters (gas \& diesel)
DPlants
$\square$ Sludge from sand/oilwater separators
Crushed non-terne plated oil fiters

Tanks

REQUIRED: WASTE GENERATOR SIGNATURE

Initials: (If inilialed, no radiological clearance is necessary.)

The above mentioned waste was generated outside of a Controlled Waste Manar knowledge, does not contain radiological materials.

To the best of my knowledge, the waste described above contains only those $m$ site. I have verified this through the waste characterization method identified ab prohibited and allowable waste items.

Print Name: SHaughin Buruison

Signabure: Date: $, 0 / 2,06$

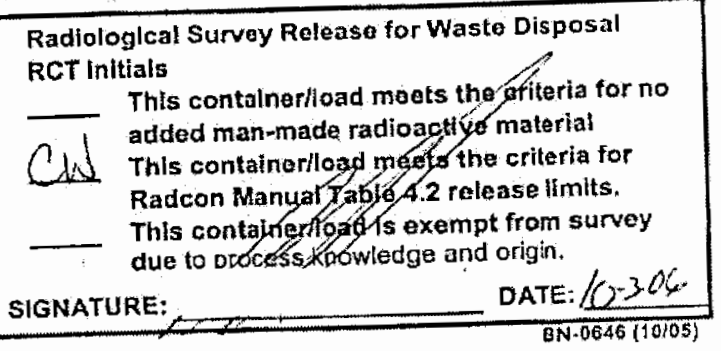

Radiologlcal Survey Release for Waste Disposal RCT Initials This containeriload moets the ofiteria for no added man-mada radioagtíy material Radcon Manual yabje, 4.2 release ilmits. This contaureufior is exempt from survey due to orocess knowledge and origin. DATE: $/ 0+3.06$

Note: Food waste, office trash andior animal carcasses are considered not to contain added radioactivity, and therefore do not require a radiological clearance.

SWO USE ONLY

Load Weight (net from scale of estmate) 15000 Signalure of Cetifier 1

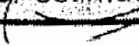




\section{BechteL Nevada NTS Landfill Load Verification}

(Waste definitions are avallable on page 2)

SWO USE (Circle One Area) AREA 23,6 , 9 , LANDFILL

For waste characterization, approval, andlor assistance, contact Solid Waste Operation (SWO) at $5-7898$.

REQUIRED: WASTE GENERATOR INFORMATION

Waste Generator: SHAkghn BuRNison

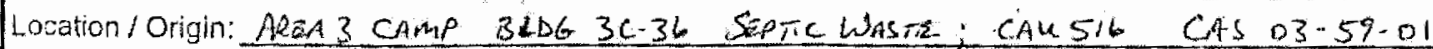

Waste Category: (check one) $\square$ Commercial $\square$ industrial

Waste Type: $\square$ NTS $\square$ Putrescible DFFCO-nsite $\square$ WAC Exception

(check one) $\square$ Non-Putrescible $\square$ Asbestos Containing Material $\square$ FFACO-offsite Historic DOENV

Pollution Prevention Category: (check one) [Q] Environmental management $\square$ Defense Projects

Pollution Prevention Category: (check one) $\quad[\mathrm{Q}$ Clean-Up $\square$ Rouline

Method of Characterization: (check one) $\square$ Sampling \& Aralysis $\square$ Process Knowedge $\square]$ Contents

Prohibited Waste Radioactive waste; RCRA waste; Hazardous waste; Free liquids, PCBs abovo TSCA regulatory levels-, and Mledical

at all three NTS landfills: wastes (needles, sharps, bloody clothing?.

Additional Prohibited Waste Sewage Sludge; Animal carcasser-, Wet garbage (food waste); and Friable asbestos at the Area 9 U10c Landfill:

\section{REQUIRED: WASTE CONTENTS ALLOWABLE WASTES}

Check all allowable wastes that are contained within this load:

NOTE: Wasto disposed at the Area 6 Hydrucarbon Landfil must have come into canlact with petroleum hydrocarbons or coolants such as: gasoline (no benzene, leadl; jet fuel; diesel fuel; lubricants and hydraulics; Kerosene; asphaltic petroleuni hydrocarbon; and ethylene glycol.

Acceptable waste at any NTS landfill: $\square$ Paper $\square$ Rocks/ unaltered geologic materials $\square$ Emply containers
$\square$ Asphalt
[ Meta!
$\square$ Wood
Q Soil
$\square$ Rubber (excluding ires)
$\square$ Demolition debris

J Plastic

D. Wire

[Cable [] Cloth

$\square$ Insulation (non-Asbestosform)

Cement \& concrete

Manufactured ifems: (swamp coolars, furniture, rugs, carpet, electronic components, PPE, elc.)

Additional waste accepted at the Arca 23 Mercury Landfill: $[$ Office waste $\square$ Food Waste $\square$ Animal Carcasses

G Asbestos: $\square$ Friable $\square$ Non-Friable (contact Swo if regulated load) Quantity:

Additional waste accepted at the Area 9 U10c Landfill:
[Non-friable asbestos
[] Drained automobiles and military vehictes
Solid ractions from send/oil/water separators
Wight ballasts (contact SwO)
Drained fuel filters (gas \& diesel)
[] Deconned Underground and Above Ground
Hydrocarbons (contact SWO)
Tanks

Additional waste accepted at the Area 6 Hydrocarbon Landfitl:
$\square$ septic sludge $\square$ Ragis
Orained fuel filters (gas \& diesél)
Crushed non-terne plated oil filters
7 Plants
Siudge from sand/oilwater separators
PCBs below 50 parts per million

Initials: SB (If initialed. no radiological clearance /s necessary.)

\section{REQUIRED: WASTE GENERATOR SIGNATURE}

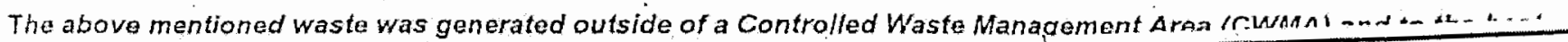
knowledge, does not contain radiological materials.

To the best of my knowledge, the waste described above contains only those mi site. I have verified this through the waste characterization method identified ab. orohibited and allowable waste items.

Print Name: SHAUGNN RURNison

ignature:

Date: $10 / 2 / 06$

Radiological Survey Release for Waste Disposal RCT Inltials

This containeriload meots thecriteria tor no

added man-made radioactive material

Q. This container/load megts the criteria for

Radcon Manual Tabjo 4.2 release llmits. Radcon Manual containetroat is exempt from survey

due to process thowledge and origin.

SIGNATURE DATE: $\angle 2 \alpha$

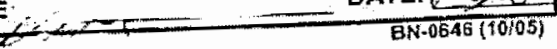

lote: Food waste, office trash andior animal carcasses are considered not to contain added radioactivity, and therefore do not require a radiclogica! clearance.

WO USE ONLY

oad Weight (net from scale or (stimate) 20,0 t

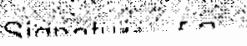


For waste characterization, approval, andlor assistance, contact Solid Waste Operation (SWO) at 5-7898.

$$
\text { REQUIRED: WASTE GENERATOR INFORMATION }
$$

(This form is for rolloffs, dump trucks, and other onsite disposal of materials.)

Waste Generator: Sithugut BuR Buisow

Location /Origin: AREA 3 MANCA4AP BDC $3 C$.

CAn 516 cas $03.59-01$

HC IMPACTED SEMTC WASTE

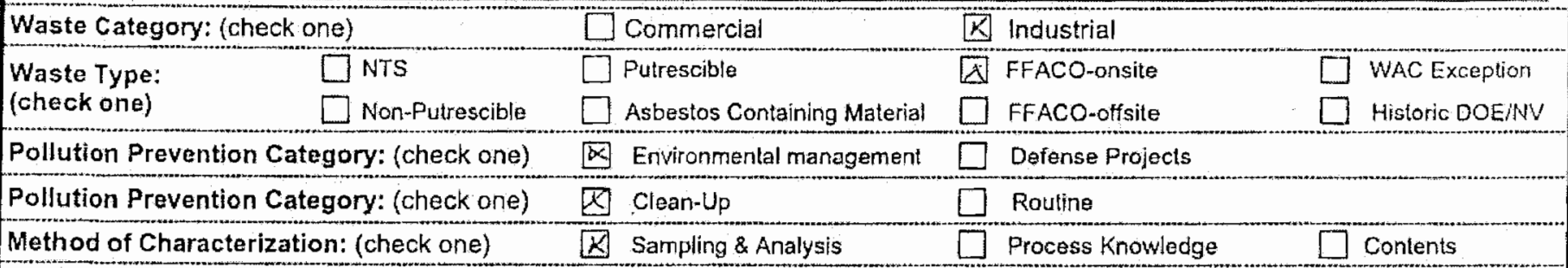

Prohibited Waste Radioaclive waste; RCRA waste; Hazardous waste; Free liquids, PCBs above TSCA regulatory levels-, and Medical at all three NTS landfills: wastes (needles, sharps, bloody clothing).

Additional Prohibited Waste Sewage Sludge; Animal carcasses-, Wet garbage (food waste); and Friable asbestos at the Area 9 U10c Landfill:

\section{REQUIRED: WASTE CONTENTS ALLOWABLE WASTES}

Check all allowable wastes that are contained within this load:

NOTE: Waste disposed at the Area 6 Hydrocarbon Landfill must have come into contact with petroleum hydrocarbons or coolants such as: gasoline (no benzene, lead); jet fuel; diesel fuel; lubricants and hydraulics; kerosene; asphaltic petroleum hydrocarbon; and ethylene glycol.
Acceptable waste at any NTS landfill:
Asphalt $\square$ Metal
$\square$ Paper
$\square$ Rocks / unaltered geologic materials
Emply containers
Br Plastic
$\square$ Wire
$\square$ Wood
[Dol
$\square$ Rubber (excluding tires)
$\square$ Cable $\square$ Cloth
$\square$ insulation (non-Asbestosform)
$\square$ Demolition debris
$\square$ Manufactured items: (swamp coolers, furniture, rugs, carpet, electronic components, PPE, etc.)
Additional waste accepted at the Area 23 Mercury Landfill: $\square$ Office waste $\square$ Food Waste $\square$ Animal Carcasses
$\square$ Asbestos: $\square$ Friable $\square$ Non-Friable (contact SWO if regulated load) Quantity:
Additional waste accepted at the Area 9 U10c Landfill:
$\square$ Non-friable asbestos
$\square$ Drained automobiles and military vehicles
Solid fractions from sand/oil/water separators
$\square$ Light ballasts (contact SWO)
Drained fuel fillers (gas \& diesel)
Deconned Underground and Above Ground
[ Hydrocarbons (contact SwO) Tanks

Additional waste accepted at the Area 6 Hydrocarbon Landfill:
$\square$ Septic sludge $\square$ Rags
$\square$ Drained fuel filters (gas \& diesel)
Crushed non-terne plated oil filters
$\square$ Plants
[ Sludge from sand/oil/water separators
PCBs below 50 parts per million

\section{Q KCW 10/2106 REQUIRED: WASTE GENERATOR SIGNATURE \\ Initials: $S B$ (II initialed, no radiological clearance is necessary.)}

The above mentioned waste was generated autside of a Controlled Waste Managem knowledge, does not contain radiological materials.

To the best of my knowledge, the waste described above contains only those mat site. I have verified this through the waste characterization method identified abol prohibited and allowable waste items.

Print Name: SHAUGHA BuENison

Signature: Date: $9 / 2,7 / 06$

Radiological Survey Release for Waste Disposal RCT Inttials

This contalner/load meets the criteria for no added man-made radioactive material

Cl This container/load meets the criteria for Radcon Manual Table 4.2 release limits. This containerlload is exempt from survey due to process knowledge and origin.

SIGNATURE: DATE: $10 \cdot 300$ BN.0646(10/05)

Note: Food waste, office trash and/or animal carcasses are considered not to contain added radioactivity, and therefore do not require a radiological clearance. 


\section{Bechtel Nevada NTS Landfill Load Verification}

(Waste definitions are avallable on page 2)

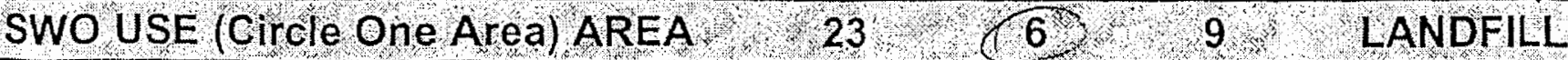

For waste characterization, approval, andior assistance, contact Solid Waste Operation (SWO) at 5-7898.

\section{REQUIRED: WASTE GENERATOR INFORMATION}

(This form is for rolloffs, dump trucks, and other onsite disposal of materials.)

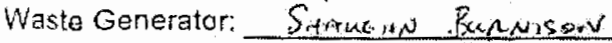

Phone Number: $5-9324$

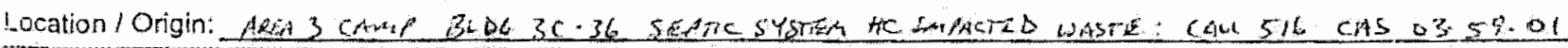

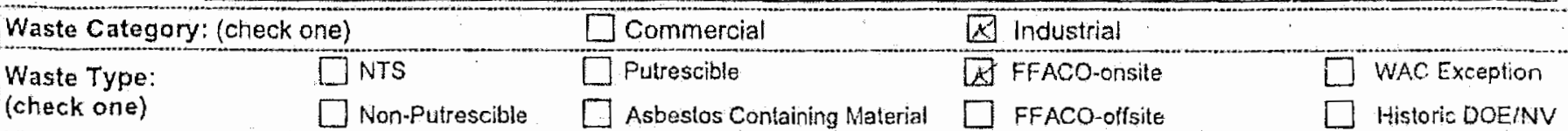

Pollution Prevention Category: (check one) $[\chi$ Environmental management $\square$ Defense Projects

Pollution Prevention Category: (check one) $\square$ Clean-Up $\square$ Routine

Method of Characterization: (check one) $\quad[$ Sampling \& Analysis $\square$ process knowledge $\square$ Contests

Prohibited Waste Radioactive waste: RCRA waste; Hazardous wasle; Free hiquids, PCBs above TSCA regulalory levels-; and Medical

at all three NTS landfills: . wastes (needles, sharps, bloody ciothing)

Additional Prohibited Waste Sewage Sludge; Animal carcassos-, Wet garbage (food waste); and Friable asbestos

at the Area $9 \cup 10 \mathrm{c}$ Landfill:

REQUIRED: WASTE CONTENTS ALLOWABLE WASTES

Check all allowable wastes that are contained within this load:

NOTE: Wasle disposed at the Area 6 Hydrocarbon Landfill must have come into contact with petroleum hydrocarbons or coolants such as: gasoline (no benzene, lead) jet fuel; diesel fuel lubricants and hydraulics; kerosene; asphallic pelroleurn hydrocarbon; and ethylene glycol.

Acceptable waste at any NTS landfill: [] Paper $\square$ Rocks / unaltered geologic materials [] . Empty containers

Eífshalt $\square$ Metal Wood $\square$ Soil $\square$ Rubber (excluding tires)

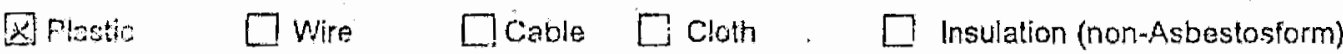

[] Denolition debris

[.] Manufactured items: (swamp coolers, furniture, rugs, carpet, electronic components, PPE, etc.)

Additional waste accepted at the Area 23 Mercury Landifi: $\square$ Office waste $\square$ Food Waste $\square$ Animal Carcasses

1 Asbestos: $\square$ Friable $\square$ Non-Friable (contact Swo if regulated load) Quantity:

Additional waste accepted at the Area 9 U10c Landill:
DNon-friable asbestos
Drained automobiles and military vehicles
Solid fractions from sand/oil/water separators
[.] Light ballasts (contact SwO)
$\square$ Drained fuel filiers (gas \& diesel)
Deconned Underground and Above Ground
[] Hydrocarbons (contact SWO)
Tanks

Additional waste accepted at the Area 6 Hydrocarbon Landfill:
$\square$ septic sludge $\square$ Rags
Drained fuel filters (gas \& diesel)
Crushed non-terne plated oil filters
EPlants lo do
Sludge from sand/oil/water separators
PCBs below 50 parts per million

Kin tom

Initials 52

)

\section{REQUIRED: WASTE GENERATOR SIGNATURE}

(_Larice is necessary.)

The above mentioned waste was generated outside of a Controlled Waste Management Area (CWMAl and to the best of miv knowledge, does not contain radiological materials.

To the best of my knowledge, the waste described above contains only those mat site. I have verified this through the waste characterization method identified abov prohibited and allowable waste items.

Print Name: Shavgho Burnisons

Signature: Date: $9 / 28 / 06$ Radiological Survey Release for Waste Disposal RCT inltials

This container/load meets the criteria for no added man-made radioactlve material

CW This containeriload meets the critoria for Radcon Manual Tole 4.2 release ilmits. This containerllbad is exempt from survey due to process knowledge and origin.

SIGNATURE. DATE: $\angle 4-3 \cdot C 4$

Note: Food waste, office trash and/or animal carcasses are considered not to contain added radioectivity, and therefore do not require a radiological clearance. 
For waste characterization, approval, andlor assistance, contact Solid Waste Operation (SWO) at 5-7898.

$$
\text { REQUIRED: WASTE GENERATOR INFORMATION }
$$

(This form is for rolloffs, dump trucks, and other onsite disposal of materials.)

Waste Generator: SHAwghn RuRNiSON Phone Number: 5-9328

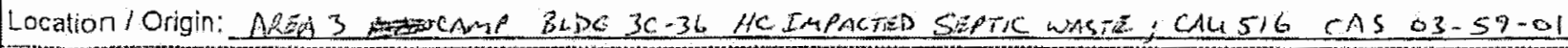

Waste Category: (check one)

Waste Type:

(check one)

$\square$ NTS

$\square$ Non-Putrescible

Pollution Prevention Category: (check one)

Pollution Prevention Category: (check one)

Method of Characterization: (check one)

$\begin{array}{lll}\square \text { Commercial } & \square \text { Industrial } & \\ \square \text { Putrescible } & \square \text { FFACO-onsite } & \square \text { WAC Exception } \\ \square \text { Asbestos Containing Material } & \square \text { FFACO-offsite } & \square \text { Historic DOENNV } \\ \square] \text { Environmental management } & \square \text { Defense Projects } & \\ \square \text { Clean-Up } & \square \text { Routine } & \\ \square \text { Sampling \& Analysis } & \square \text { Process Knowladge } & \square \text { Contenis }\end{array}$

Prohibited Waste

Radioactive wasle; RCRA waste; Hazardous waste; Free liquids, PCBs above TSCA regulatory levels-, and Medical

at all three NTS landfills: wastes (needles, sharps, bloody clothing).

Additional Prohibited Waste Sewage Sludge; Animal carcasses-, Wel garbage (food waste); and Friable asbestos at the Area 9 U10c Landfill:

\section{REQUIRED: WASTE CONTENTS ALLOWABLE WASTES}

Check all allowable wastes that are contained within this load:

NOTE: Waste dispesed at the Area 6 tyydrocarbon Landfill must have come into contact with pelroleum hydrocarbons or coolants such as: gasoline ine benzene, lead); jel fuel; diesel fuel; lubricants and hydraulies; kerosene; asphallic petroleurm hydrocarbon; and ethylene giycol

Acceptable wasie at any NTS landfill: $\square$ Paper $\square$ Rocks / unaltered geologic materials $\square$ Emply containers
E Asphalt
Xetal
$\square$ Wood
[A] Soll
$\square$ Rubber (excluding tires)
Ij Wirs
$\square$ Cable
[.] Cloth
Insulation (nion-Asbestosform)
Demolition debris
W] Plastic

D. Manteattired itern: (swam; coolers, furniture, rugs, carpet, electronic components, PPE, etc.)

Additional wastu accepted at the Area 23 Mercury Landfill: $\square$ Office waste $\square$ Food Waste $\square$ Animal Carcasses

[] Asbestos: D Friable [] Non-Friable (contact SWo if regulated load) .Quantity:

Additional waste accepted at the Area 9 U10c Landfill:
$\square$ Non-friatile asbestos
$\square$ Drained automobiles and military vehicles
Solid fractions from sand/oil/water separators
[.] Light baliasts (contact SWO)
$\square$ Drained fuel filters (gas \& diesel)
Deconned Underground and Above Ground
C. Hydrocarbons (conlact SWO)
Tanks

sdditional waste accepted at the Area 6 Hydrocarbon Landfill:
$\square$ septic sludge $\square$ Rags
$\square$ Drained fuel filters (gas \& diesel)
Crushed non-terne plated oil filters
$\frac{\square \text { plants }}{\text { Initials: } 15 B \text { / }}$
Sludge from sand/oil/water separators
$\square$ PCBs below 50 parts per million
Initials: $3 B$ / (If intialed, no radiological clearance is necessary.)

The above mentioned waste was generated outside of a Controlled Waste Management Area (CWMA) and to the best of mV knowledge, does not contain radiological materials.

To the best of my knowledge, the waste described above contains only those mat site. I have verified this through the waste characterization method identifled abol probibited and allowable waste items.

Print Name: Shavenn Burnesuen

Signature: Date: $1 / 27 / 06$

Radiological Survey Release for Waste Disposal RCT Initials

This containerload meets the critorla for no added man-made radloactive material c. This containeriload meets the criterla for Rad con Manual Table 4.2 release limits. Radcon Manual Table 4.2 release limits. This containerioge is exempt origin.

SIGNATURE: DATE: $\angle 0 \cdot \dot{10} 0$

Note: Food waste, office trash and/or animal carcasses are considered not to contain added radioactivity, and therefore do not require a radiological clearance. 


\section{Bechtel Nevada NTS Landfill Load Verification}

(Waste definitions are available on page 2)

\section{SWO USE (Circle One Area) AREA 23 \\ 6 \\ 9 \\ LANDFILL}

For waste characterization, approval, andlor assistance, contact Solid Waste Operation (SWO) at 5-7898.

\section{REQUIRED: WASTE GENERATOR INFORMATION}

(This form is for rolloffs, dump trucks, and other onsite disposal of materials.)

Waste Generator: SHAuGi+N BuRNison

Phone Number: $5-9328$

Location/Origin: AREA 3 MANCALP BLDG $3 C-36$ CAW 516 CAS O3-59-01 SEDTC LMSTE

Waste Category: (check one)

Waste Type: $\square$ NTS $\square$ Putrescible $\$$ FFACO-onsile

(check one)

$\square$ Non-Putrescible

Asbeslos Contajning Materia!

D. FACO-onsile

WAC Exception

Polfution Prevention Category: (check one)

Q Environmental management

$\square$ FFACO-offsile

Historic DOE/NV

Pollution Prevention Category: (check one)

Method of Characterization: (check one)

(X) Clean-Up

[X] Sampling \& Analysis

$\square$ Defense Projects

$\square$ Routine

Prohibited Waste Radioactive waste: RCRA waste; Hazardous waste; Free líquids, PCBs above TSCA regulatory levels-, and Medical at all three NTS landfills: wastes (needles, sharps, bloody clolhing).

Additional Prohibited Waste Sewage Sludge; Animal carcasses-, Wel garbage (food waste); and Friable asbestos

at the Area 9 U10c Landfill:

\section{REQUIRED: WASTE CONTENTS ALLOWABLE WASTES}

Check all allowable wastes that are contained within this load:

NOTE: Waste disposed at the Area 6 Hydrocarbon Landfill must have come into contact with petroleum hydrocarbons or coolants such as: gasoline (no benzene, lead); jet fuel; diesel fuel; lubricants and hydraulics; kerosene; asphaltic pelroleum hydrocarbon; and ethylene glycol.
Acceptable waste at any NTS landfill:
$\square$ Paper
[A Rocks / unaltered geologic materials
$\square$ Empty containers
$\square$ Asphalt $\square$ Metal $\square$ wood $\square$ Soil
Q. Plastic
$\square$ Wire
Cable
$\square$ Cloth
$\square$ Rubber (excluding tires)
$\square$ Insulation (non-Asbestosform)
$\square$ Demolition debris

$\square$ Manufactured items: (swamp coolers, furniture, rugs, carpet, electronic components, PPE, etc.)

Additional waste accepted at the Area 23 Mercury Landfill: $\square$ Office waste $\square$ Food Waste $\square$ Animal Carcasses

$\square$ Asbestos: $\square$ Friable $\square$ Non-Friable (contact SWO if regulated load) Quantity:

Additional waste accepted at the Area 9 U10c Landfill:
$\square$ Non-friable asbestos
$\square$ Drained automobiles and military vehicies
Solid fractions from sand/oil/water separators
$\square$ Light ballasts (contact SWO)
$\square$ Drained fuel filters (gas \& diesel)
Deconned Underground and Above Ground Tanks
$\square$ Hydrocarbons (contact SWO)

Additional waste accepted at the Area 6 Hydrocarbon Landfill:

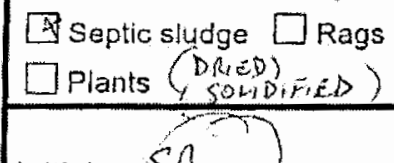

$\square$ Drained fuel filters \{gas \& diesel\}

Crushed non-terne plaled oil filters

Initials: $S \Omega$ (If initialed, no radiological clearance is necessary.)

The above mentioned waste was generated outside of a Controlled Waste Management Area (CWMA) and to the best of my knowledge, does not contain radiological materials.

To the best of my knowledige, the waste described above contains only those mat site. I have verified this through the waste characterization method identified abo prohibited and allowable waste items.

Print Name: Sitatigneu Bupanison

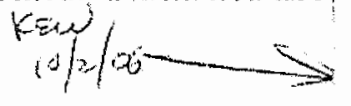

Radlological Sunvey Release for Waste Disposal RCT Initlals
- This container/load meets the criteria for no added man-made radloactive material
Gr This containerlload meets the criterla for Radcon Manual Table 4.2 release limits. This containerlogd is exampt from survey duo to process krowledge and origin.

Signature: Date: $9 / 1 / 06$ SIGNATURE: DATE: $10-2 \cdot 0$. BN-0646 (10105)

Note: Food waste, office trash and/or animal carcasses are considered not to contain added radioactivity, and therelore do hot require a radiological ciearance.

\section{SWO USE ONLY}

Load Weight (net from scale or estimate), , $C Q O O)$ Signature of Certifier: 


\section{Bechtel Nevada}

SWO USE (Circle One Area) AREA
NTS Landfill Load Verification

(Waste definitions are available on page 2)

For waste characterization, approval, andlor assistance, contact Solid Waste Operation (SWO) at 5-7898.

\section{REQUIRED: WASTE GENERATOR INFORMATION}

(This form is for rolloffs, dump trucks, and other onsite disposal of materials.)

Waste Generator: SHALCifas Bunonsow

Phone Number: 5.9328

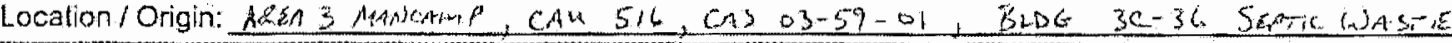

Waste Category: (check one) $\square$ Commercial $\square$ Industrial

(check one) $\square$ Non-Putrescible

$\square$ Asbestos Containing Material

$\square$ FFACO-oifsile

WAC Exception

Pollution Prevention Catogory: (check one)

Q Environnental management

Pollution Prevention Category: (check one)

Method of Characterization: (check one)

X Clean-Up

Prohibited Waste

[C. Sampling \& Analysis

$\square$ Defense Projects

at all three NTS landfills: $\quad$ wastes (needles, sharps, bloody clothing)

$\square$ Routine

Additional Prohibited Waste Sewage Sludge; Animal carcasses-, Wet garbage (food waste); and Friable asbeslos at the Area 9 U10c Landfill:

\section{REQUIRED: WASTE CONTENTS ALLOWABLE WASTES}

Check all allowable wastes that are contained within this load:

NOTE: Waste disposed at the Area 6 Hydrocarbon Landfil must have come into contact with petroleum hydrocarbons or coolants such as: gasoline (no benzene, lead); jet fuel; diesel fuel; lubricants and hydraulics; kerosene; asphaltic petroleum hydrocarbon; and ethylene glycol.

Acceptable waste at any NTS landfill: $\square$ Paper $\square$ Rocks / unaltered geologic materials $\square$ Empty containers
$\square$ Asphalt
$\square$ Metal
$\square$ Wood
[x] Soil
$\square$ Rubber (excluding tires)
$\square$ Demolition debris
Q Plastic
$\square$ Wire
$\square$ Cable $\square$ Cloth
$\square$ Insulation (non-Asbestosform)
[x Cement \& concrete

$\square$ Manufactured items: (swamp coolers, furniture, rugs, carpet, electronic components, PPE, etc.)

Additional waste accepted at the Area 23 Mercury Landfill: $\square$ Office waste $\square$ Food Waste $\square$ Animal Carcasses

$\square$ Asbestos: $\square$ Friable $\square$ Non-Friable (contact SWO if regulated load) Quantity:

Additional waste accepted at the Area 9 U10c Landfill:
$\square$ Non-friable asbestos
Drained automobiles and military vehicles
Solid fractions from sand/oil/water separators
Light ballasts (contact SWO)
Drained fuel filters (gas \& diesel)
Deconned Underground and Above Ground
$\square$ Hydrocarbons (contact SWO)
Tanks

Additional waste accepted at the Area 6 Hydrocarbon Landfill:

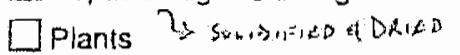

Sludge from sand/oll/water separators

Crushed non-terne plated oil filters

REQUIRED: WASTE GENERATOR SIGNATURE

Initials: $S B$ (If initialed, no radiological clearance is necessary.)

The above mentioned waste was generated outside of a Controlled Waste Management Area (CWMA) and to the best of my

knowledge, does not contain radiological materials.

To the best of my knowledge, the waste described above contains only those mat site. I have verified this through the waste characterization method ldentified abov prohibited and allowable waste itemis.

Print Name: SHAUEN BuRNSSON

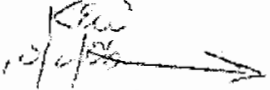

Signature: Date: $9 / n / 06$ Radlologlcal Survey Rolease for Waste Disposal RCT Initials

Thls contalnerlload meets the criteria for no

added man-made radioactive material

Can This containorlload meets the criteria for Radcon Manual Table 4.2 release limits. This containerflead is exempt from survey due to procésan knowedge and origin.

SIGNATURE: DATE: $/ 0 \cdot 2+C$ BN-0646 (10/05)

Note: Food waste, office trash and/or animal carcasses are considered not to contain added radioactivity, and therefore do not require a radiological clearance.

SWO USE ONLY

Load Weight (net from scale or estimate):

Signature of Certifier: 
THIS PAGE INTENTIONALLY LEFT BLANK 


\section{APPENDIX D}

\section{FIELD PHOTOGRAPHS}


CAU 516 Closure Report Section: Appendix D

Revision: 0

Date: April 2007

THIS PAGE INTENTIONALLY LEFT BLANK 


\section{Photographic Log}

\begin{tabular}{|c|c|c|l|}
\hline $\begin{array}{c}\text { IMAGE } \\
\text { NUMBER }\end{array}$ & DATE & $\begin{array}{c}\text { CORRECTIVE } \\
\text { ACTION SITE }\end{array}$ & \multicolumn{1}{c|}{ DESCRIPTION } \\
\hline 1 & $02 / 08 / 2006$ & CAS 03-59-01 & Septic tank location prior to corrective action \\
\hline 2 & $09 / 28 / 2006$ & CAS 03-59-01 & Septic tank location during corrective action \\
\hline 3 & $12 / 14 / 2006$ & CAS 03-59-01 & Septic tank location after corrective action \\
\hline 4 & $02 / 08 / 2006$ & CAS 03-59-02 & Septic tank location prior to corrective action \\
\hline 5 & $09 / 28 / 2006$ & CAS 03-59-02 & Septic tank location during corrective action \\
\hline 6 & $12 / 14 / 2006$ & CAS 03-59-02 & Septic tank location after corrective action \\
\hline 7 & $02 / 08 / 2006$ & CAS 06-51-01 & Pipe segment location prior to corrective action \\
\hline 8 & $09 / 28 / 2006$ & CAS 06-51-01 & Pipe segment location during corrective action \\
\hline 9 & $12 / 14 / 2006$ & CAS 06-51-01 & Pipe segment location after corrective action \\
\hline 10 & $02 / 08 / 2006$ & CAS 06-51-03 & Clean out box location prior to corrective action \\
\hline 11 & $12 / 14 / 2006$ & CAS 06-51-03 & Clean out box location during corrective action \\
\hline 12 & $12 / 14 / 2006$ & CAS 06-51-03 & Clean out box location after corrective action \\
\hline
\end{tabular}


CAU 516 Closure Report Section: Appendix E

Revision: 0

Date: April 2007

THIS PAGE INTENTIONALLY LEFT BLANK 


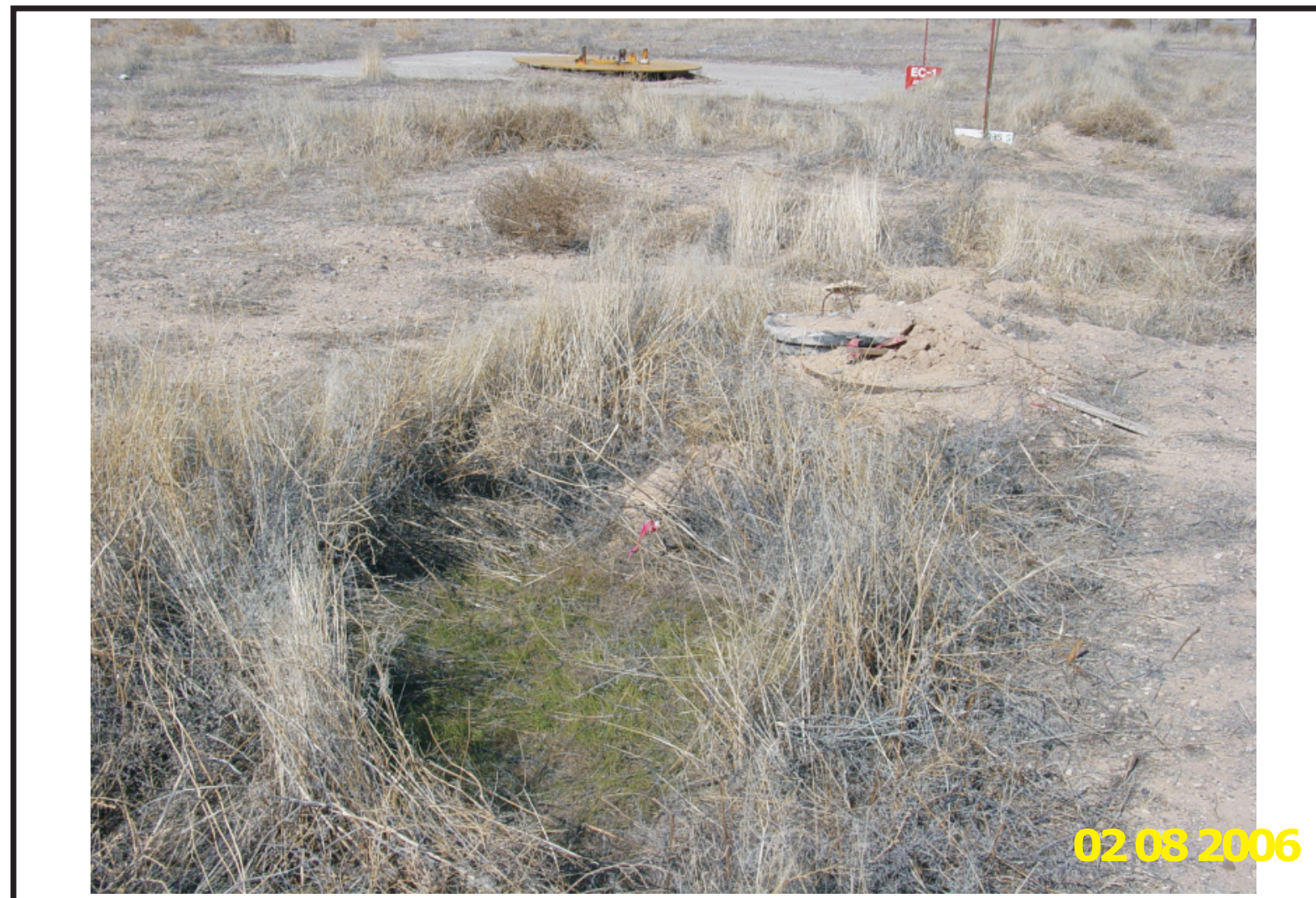

Photograph 1: CAS 03-59-01, Septic tank location prior to corrective action (02/08/2006)

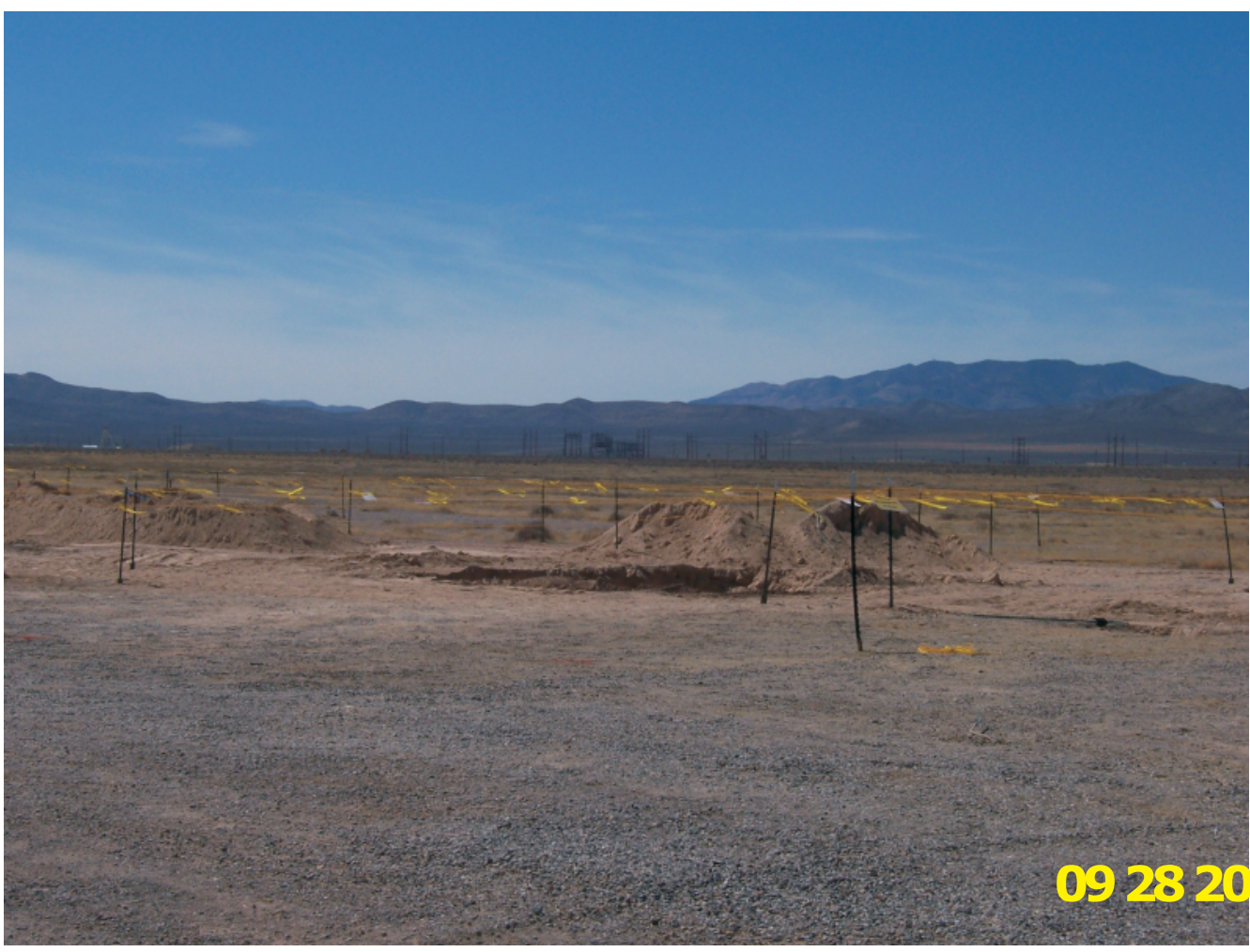

Photograph 2: CAS 03-59-01, Septic tank location during corrective action (09/28/2006) 


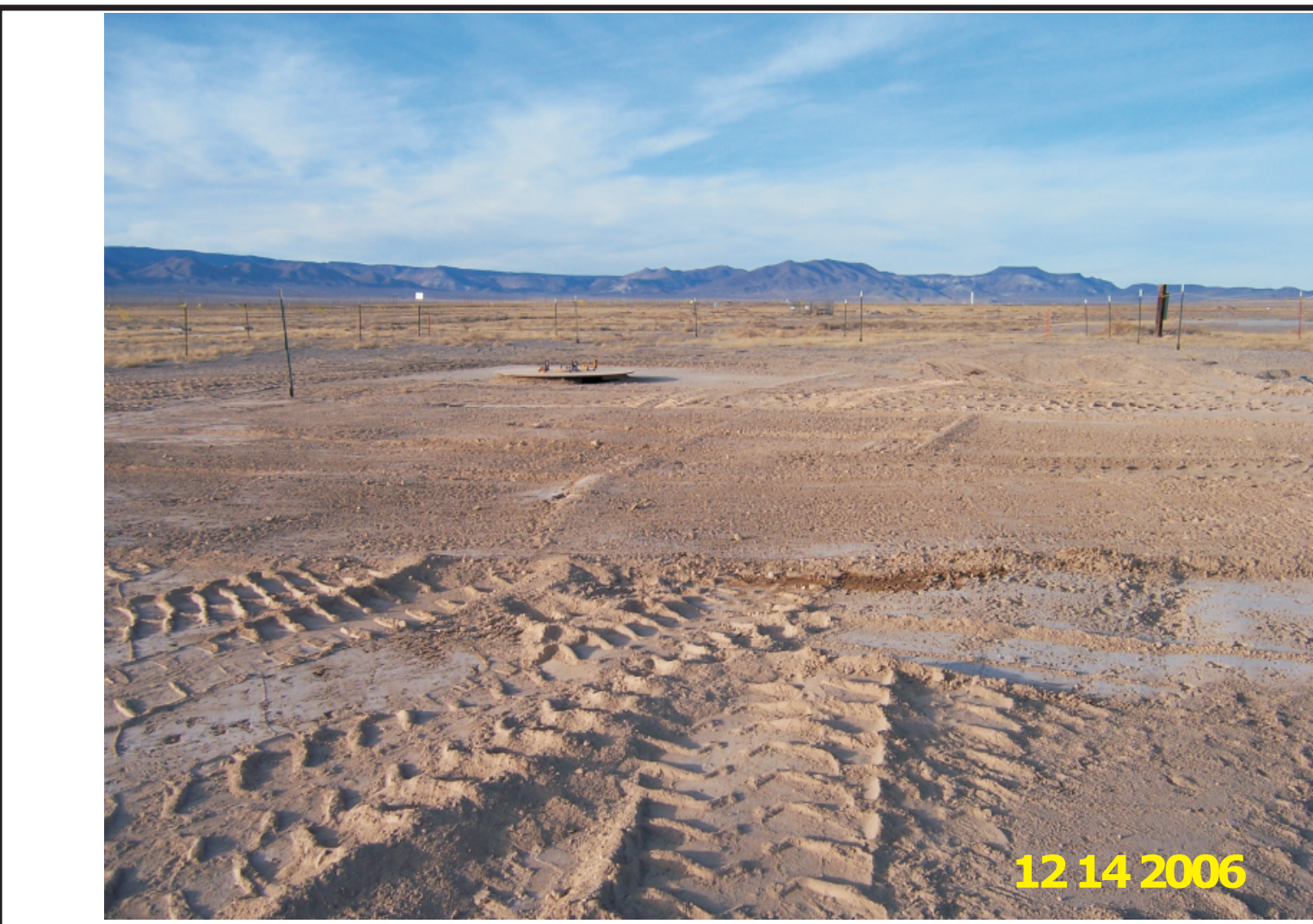

Photograph 3: CAS 03-59-01, Septic tank location after corrective action (12/14/2006)

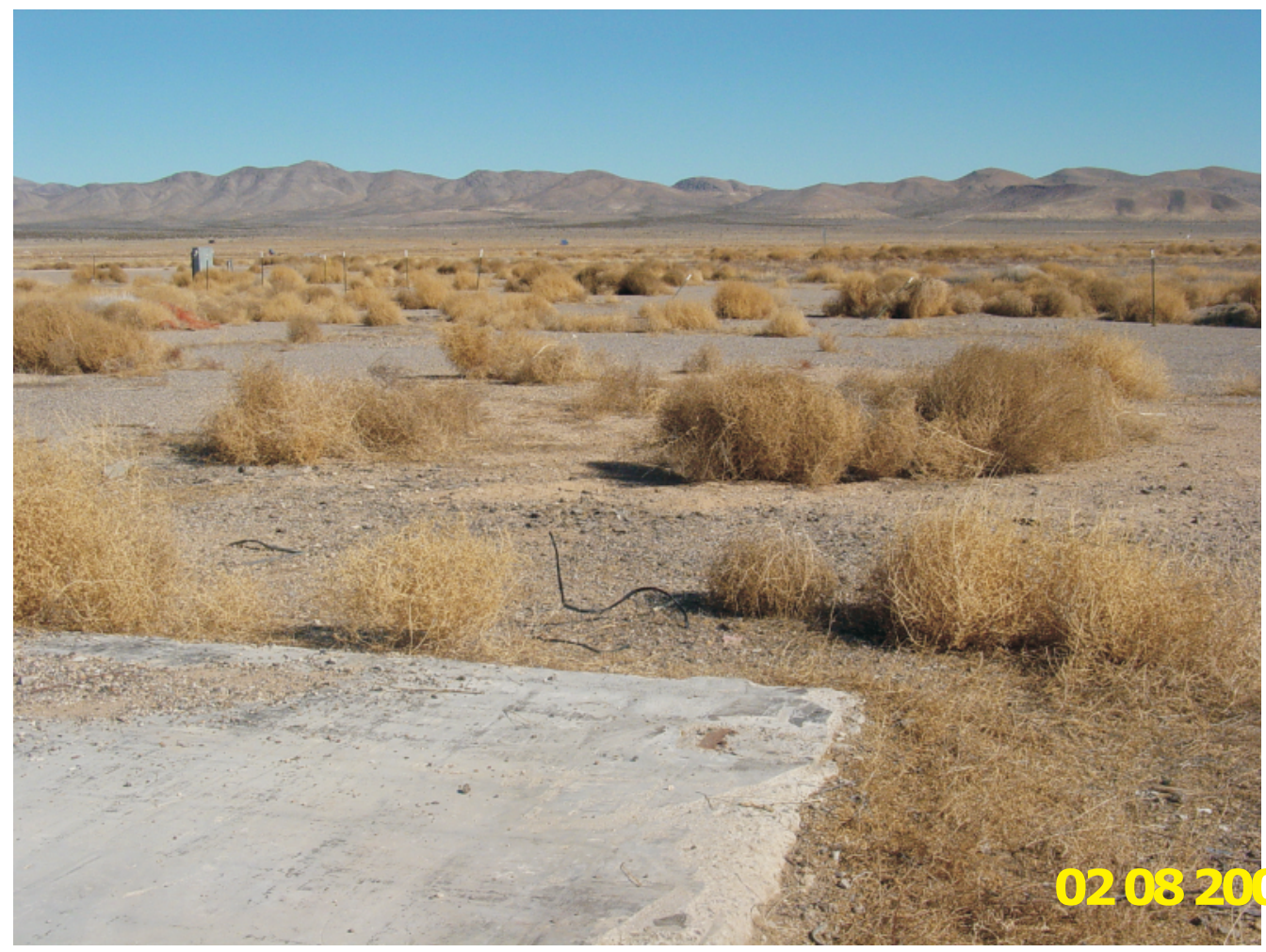

Photograph 4: CAS 03-59-02, Septic tank location prior to corrective action (02/08/2006) 


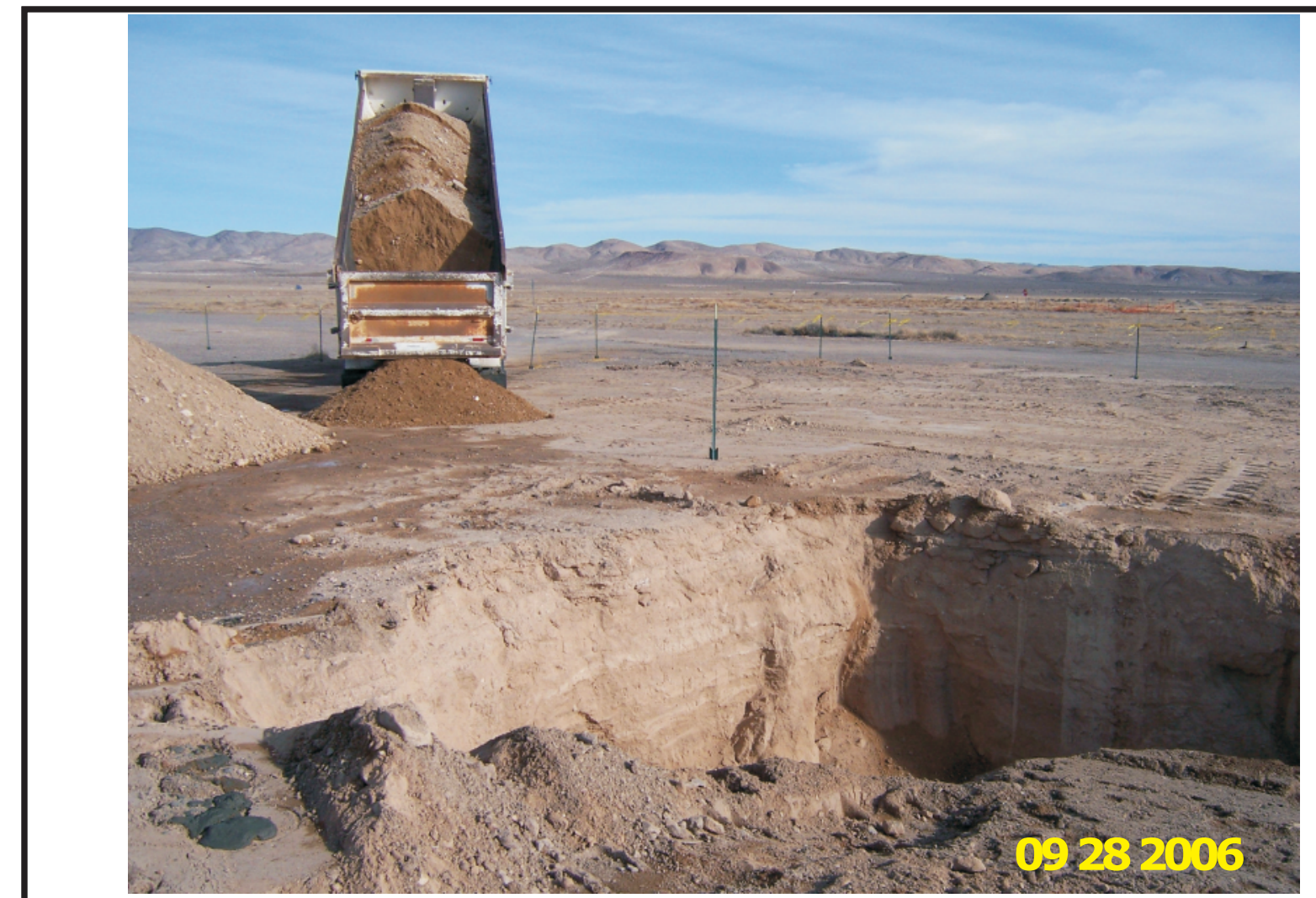

Photograph 5: CAS 03-59-02, Septic tank location during corrective action (09/28/2006)

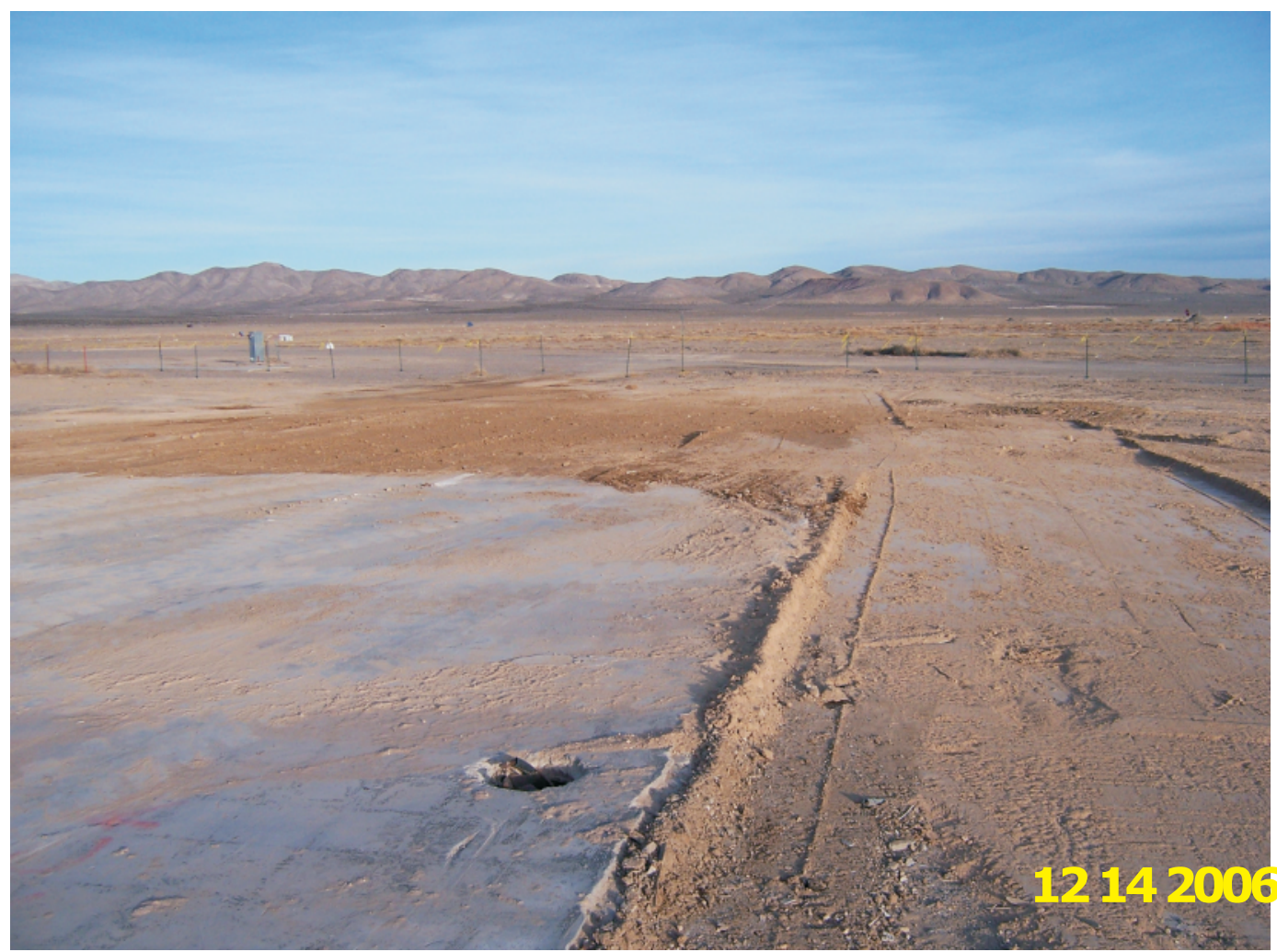

Photograph 6: CAS 03-59-02, Septic tank location after corrective action (12/14/2006) 


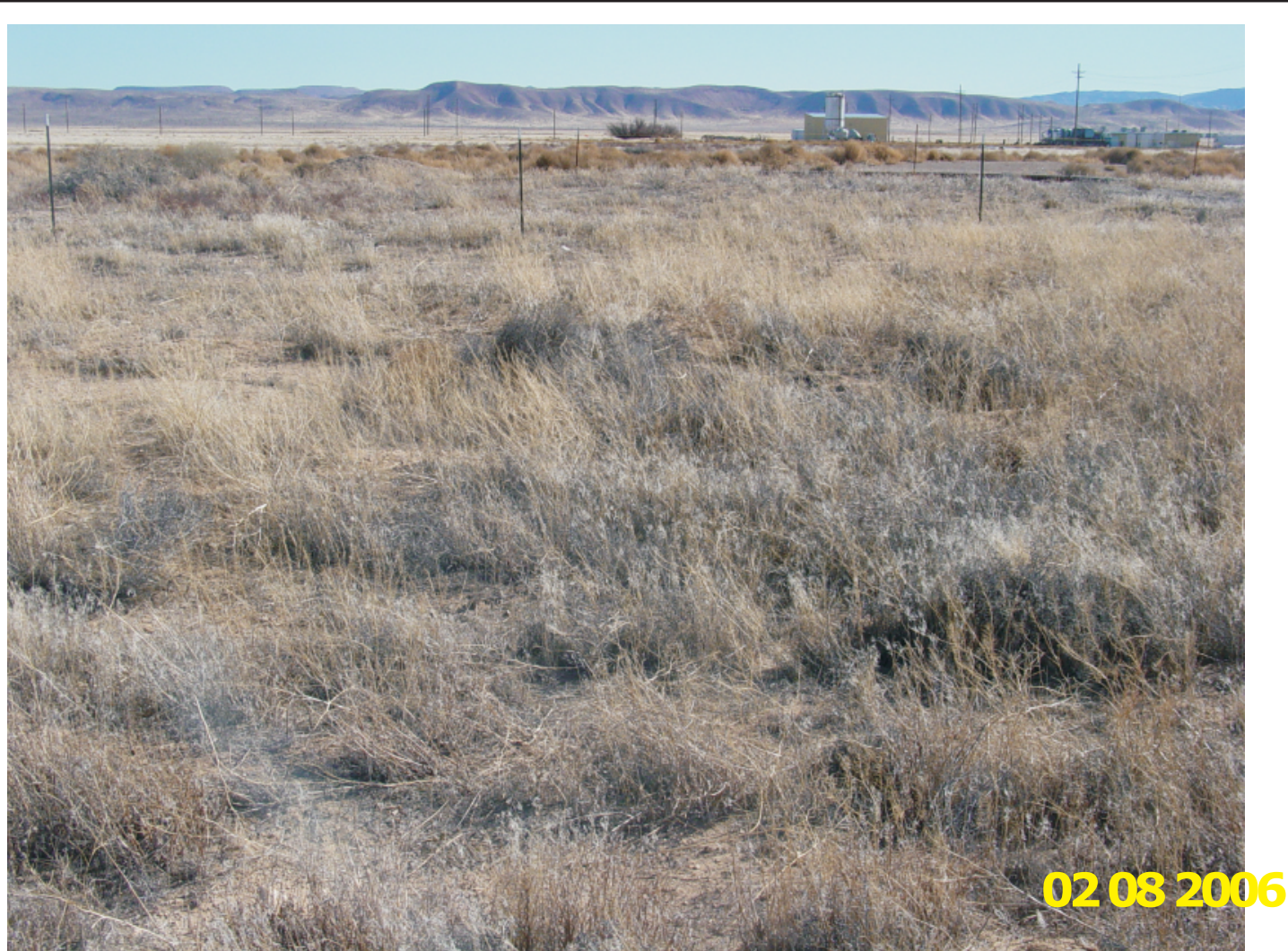

Photograph 7: CAS 06-51-01, Pipe segment location prior to corrective action (02/08/2006)

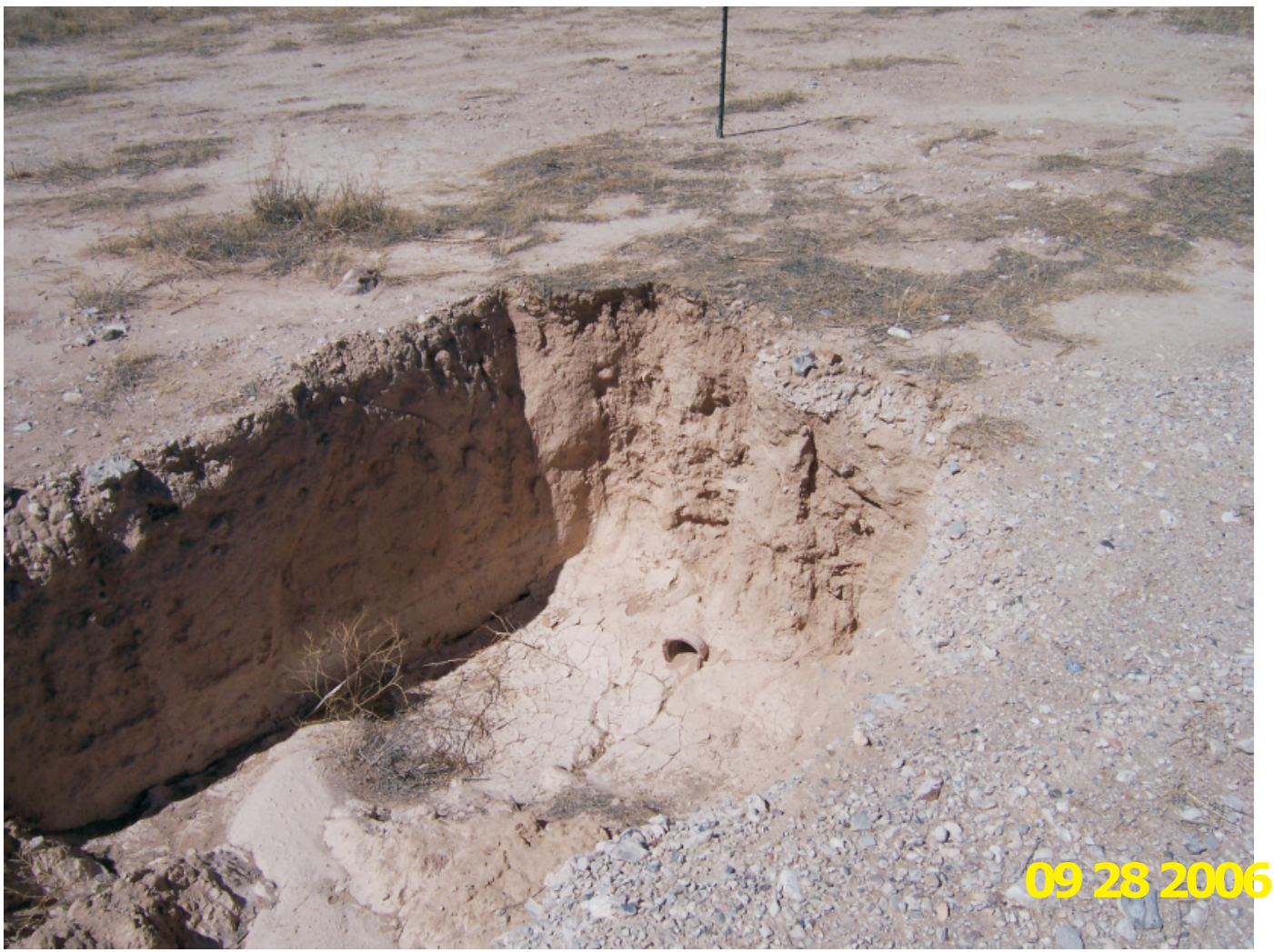

Photograph 8: CAS 06-51-01, Pipe segment location during corrective action (09/28/2006) 


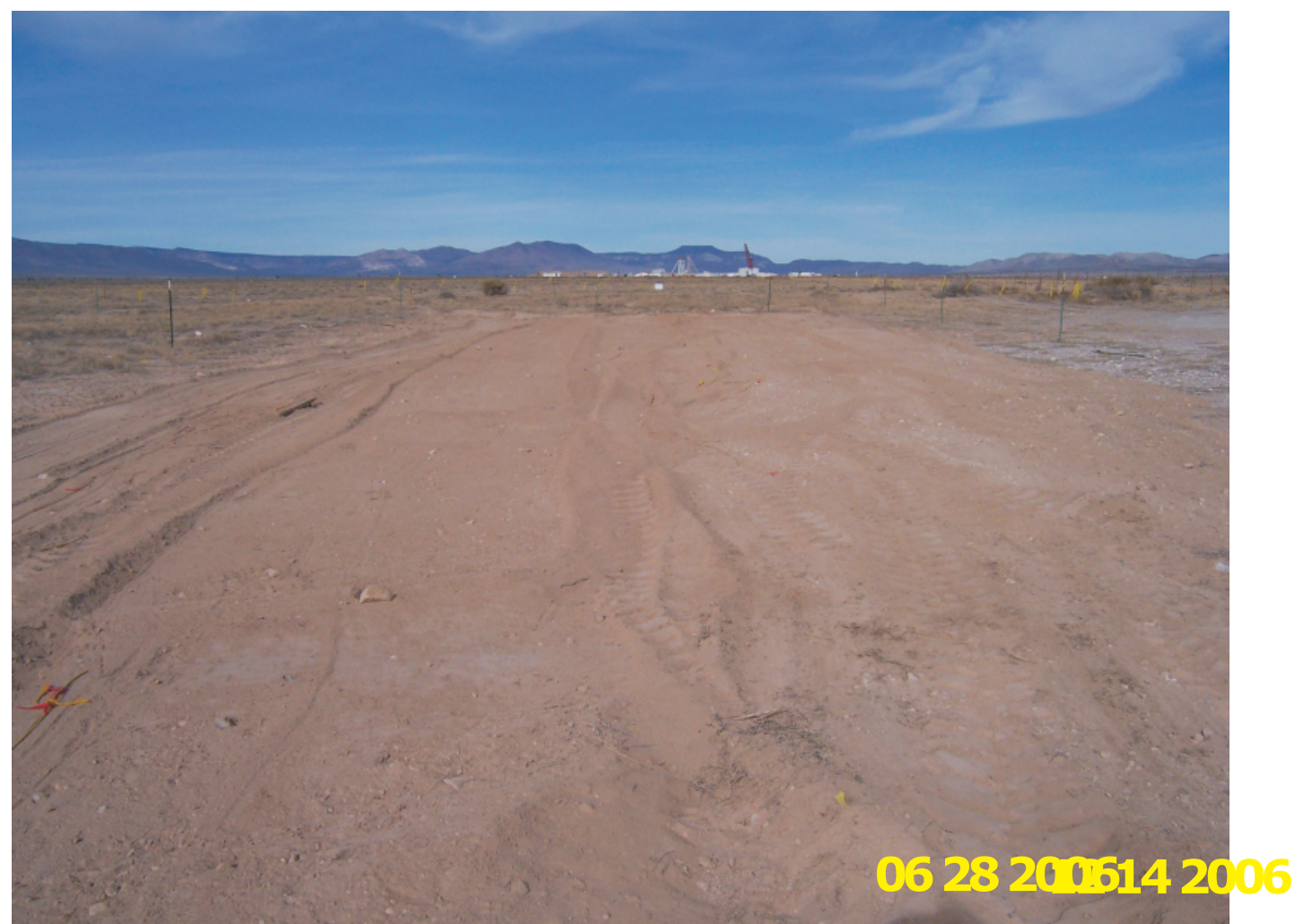

Photograph 9: CAS 06-51-01, Pipe segment location after corrective action (12/14/2006)

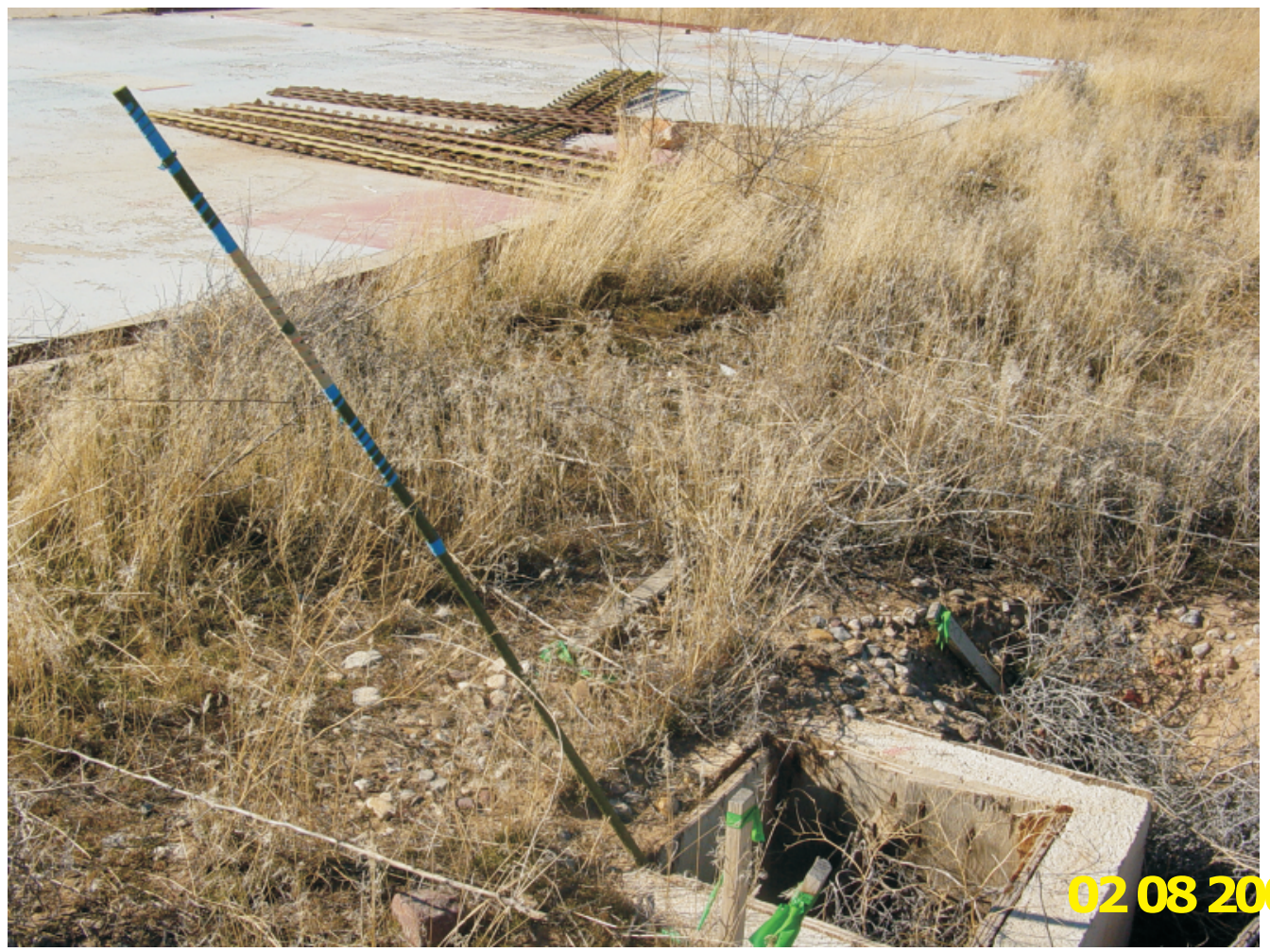

Photograph 10: CAS 06-51-03, Clean Out box location prior to corrective action (02/08/2006) 


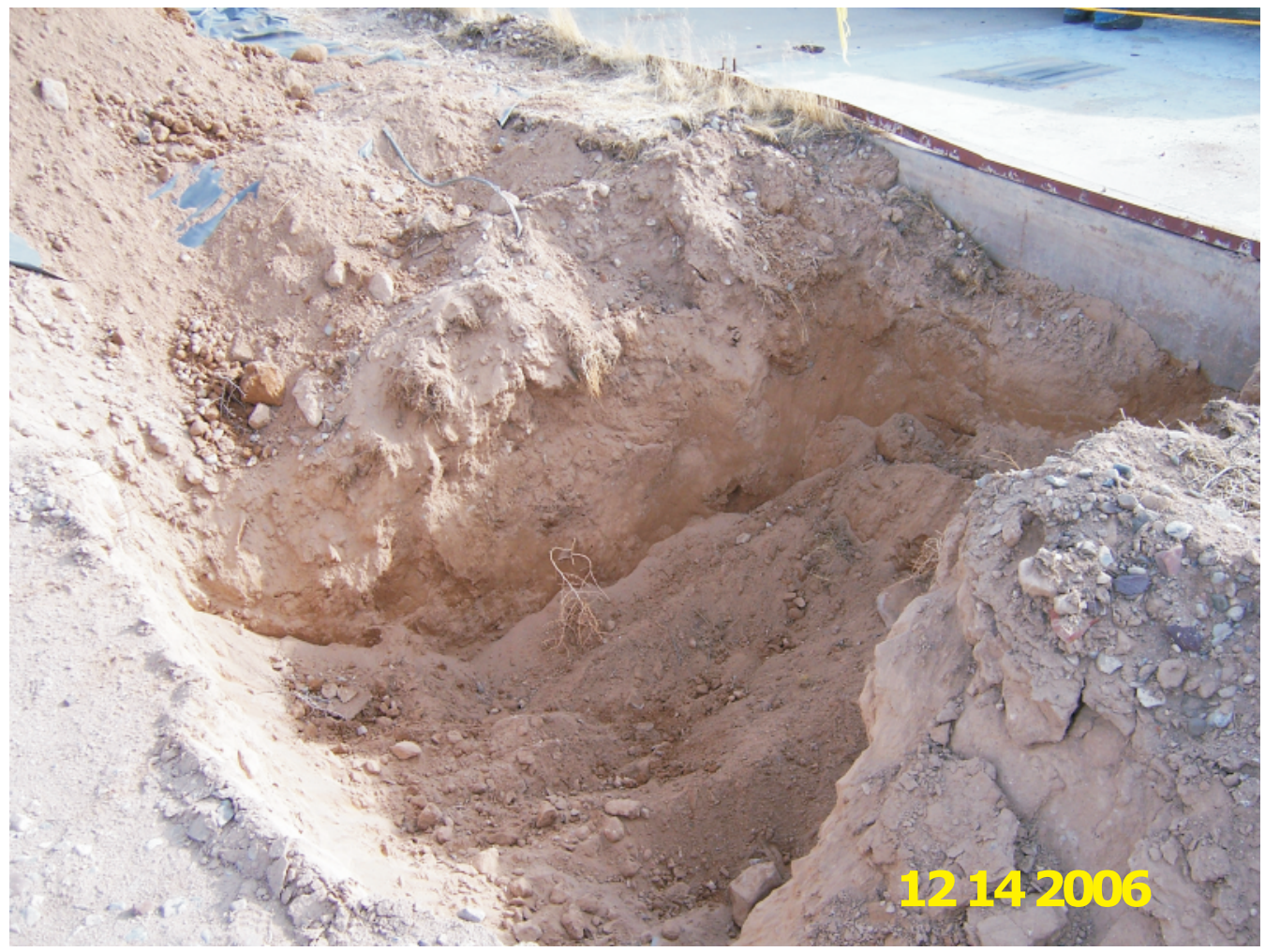

Photograph 11: CAS 06-51-03, Clean Out box location during corrective action (12/14/2006)

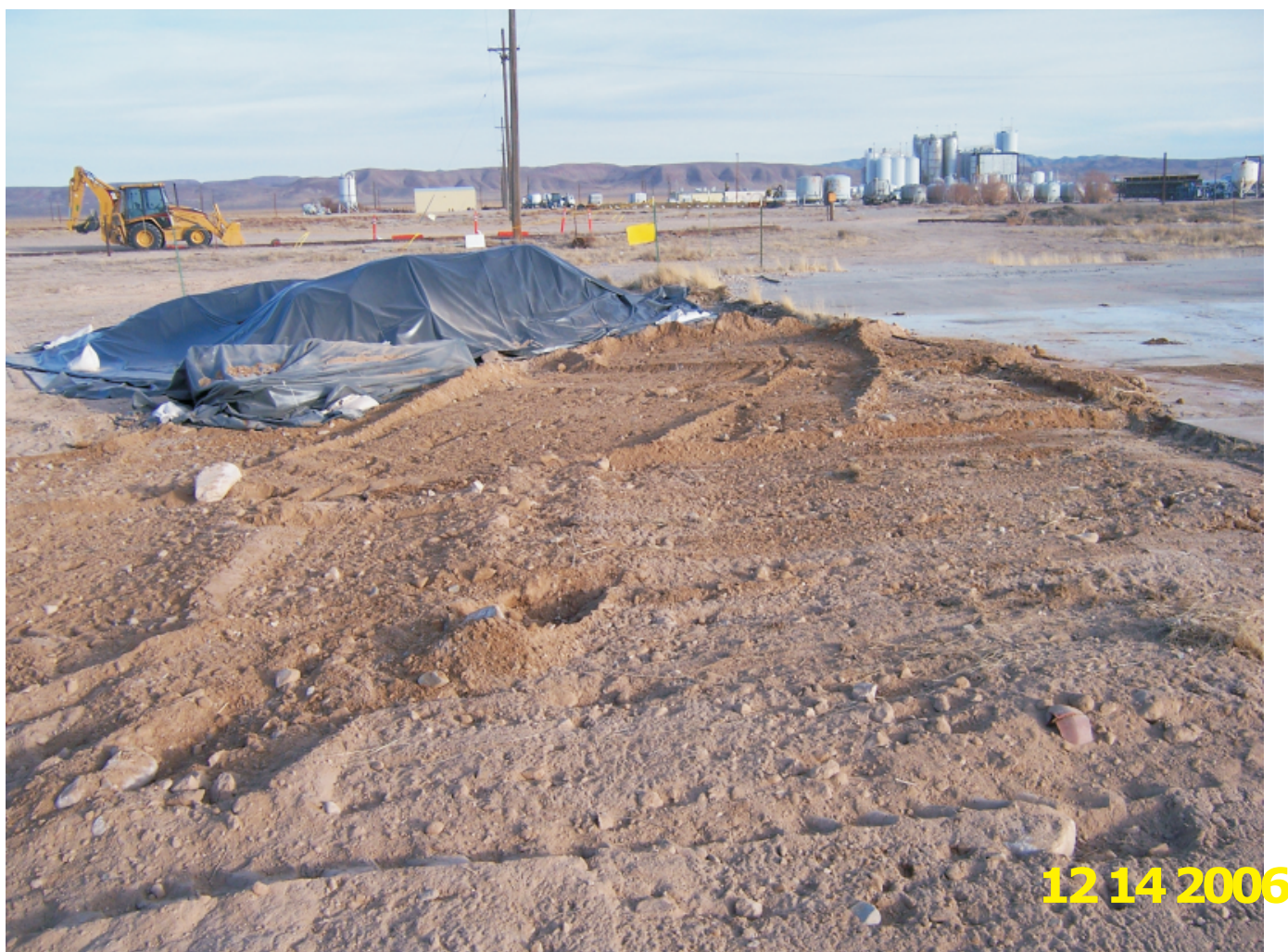

Photograph 12: CAS 06-51-03, Clean Out box location after corrective action (12/14/2006) 


\section{APPENDIX E}

\section{NATIONAL ENVIRONMENTAL POLICY ACT ENVIRONMENTAL EVALUATION CHECKLIST}


CAU 516 Closure Report Section: Appendix E

Revision: 0

Date: April 2007

THIS PAGE INTENTIONALLY LEFT BLANK 


\section{Project Location}

NTS - Areas 3 and 6

NNSAINSO Line Management Organization
Proposed By (if other than NNSANSO)

\section{NNSANSO Project/Program Manager} Janet Appenzeller-Wing

ENVIRONMENTAL CONSIDERATIONS: If any phase of the project/activity involves any of the following considerations, check yes and explain in project description. See NV-16A for consideration quidelines and examples.

\begin{tabular}{|c|c|c|c|c|c|c|c|}
\hline CONSIDERATION & YES & NO & UNK & CONSIDERATION & YES & NO & UNK \\
\hline WASTE & & & & AIR EMISSIONS & & & \\
\hline 1 Non-Rad Solid Waste & $\bar{x}$ & & & 1 Biological Material/Chemical Release & & $x$ & \\
\hline 2 Hazardous Waste & $\mathrm{x}$ & & & 2 Dust/Particulate Matter & $\mathrm{x}$ & & \\
\hline 3 Low-level Rad Waste & $\mathrm{x}$ & & & 3 Explosives & & $\bar{x}$ & \\
\hline 4 Mixed Waste & & & $x$ & 4 Diesel Generators & & $\mathrm{x}$ & \\
\hline 5 TRU/Mixed TRU Waste & & $\mathbf{x}$ & & 5 Open Burning & & $\bar{x}$ & \\
\hline 6 Wastewater (domestic/industrial) & $x$ & & & & & & \\
\hline & & & & SITE LOCATION/OTHER & & & \\
\hline HAZARDOUS MATERIALS & & & & 1 Environmental Restoration Site (CAU) & $\mathbf{x}$ & & \\
\hline 1 Petroleum/Fuel (storage/use) & $\mathbf{x}$ & & & 2 Excavation/Land Surface Disturbance & $x$ & & \\
\hline 2 Underground Storage Tanks & & $\mathrm{x}$ & & 3 Off road travel & & $\mathbf{x}$ & \\
\hline 3 Aboveground Storage Tanks & & $x$ & & 4 Biological/Tortoise Resource Area & & $x$ & \\
\hline 4 PCBs/Asbestos & & $\mathbf{x}$ & & 5 Cultural/Historic Resource Area & & $\mathbf{x}$ & \\
\hline 5 Pesticides/Herbicides & & $x$ & & 6 Change in Existing Drainage Pattern & & $\mathrm{x}$ & \\
\hline 6 Radioactive Materials & $x$ & & & 7 Impact to Environmental Monitoring System & & $\mathrm{x}$ & \\
\hline 7 Biological Materials/Símulants & & $\mathbf{x}$ & & 8 Unexploded Ordnance Area & & & $x$ \\
\hline 8 Beryllium & & $\mathrm{x}$ & & 9 Noise & $\mathrm{x}$ & & \\
\hline 9 Chemical storage/use & & $\mathbf{x}$ & & 10 Radiation controlled area & & $x$ & \\
\hline 10 Use of explosives/firearms & & $x$ & & 11 Drinking water system involvement & & $x$ & \\
\hline
\end{tabular}

DO NOT TYPE OR WRITE BELOW THIS LINE. FOR ESHD USE ONLY.

B. Is the project/activity included in the final NTS EIS and the ROD or other NEPA document? Yes $\mathrm{X}$ (complete Sections $C, D$, and $E)$ No __ (complete Sections D, E, and F)

C. This project/activity is included in the NTS EIS/ROD (or other NEPA document) under the following section and page no.: NTS/EIS Volume 1, Appendix A, A.3.1.3 - Environmental Restoration Program - Industrial Sites Project

D. Does the proposed project/activity require any local, siate, or federal permits or notifications? Yes $\mathrm{X}$ No

E. If, based on the project description and the preliminary environmental considerations noted above, the proposed action fits within a class of action listed in Subpart D of 10 CFR 1021, write in the space below, the paragraph number and short title from the appropriate table of contents of Subpart D, Appendix B, C. or D, for a CX, EA, or EIS. If the proposed action does not fit within any class of action, write "Not Listed" below.

F. NEPA COMPLIANCE OFFICER DETERMINATION OR RECOMMENDATION:

I have determined that the proposed activity as described in item $A$ above, has been adequately addressed in the document cited in item $C$ for the purpose of NEPA. No further analysis or documentation is required pursuant to NEPA.

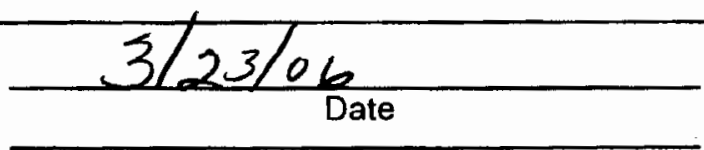




\section{CAU 516: CLOSURE/CLEANUP ACTIVITIES}

\section{Project Description}

Corrective Action Unit (CAU) 516 consists of six Corrective Action Sites (CASs). Closure activities will be conducted at four of the CASs. Activities will include solidifying septic tank contents and removing septic tanks, associated components, and piping. Each CAS is briefly described below.

\section{CAS 03-59-01 - Building 3C-36 Septic System}

This site is located in the former Area 3 Camp south of Road 3-01. The site includes a 3,000-gallon concrete septic tank containing approximately 1,430 gallons of liquid and solid waste, a distribution box, a leachfield, and associated piping. TPH is present in the septic tank at concentrations up to 7,800 milligrams/kilogram.

The liquid contents of the septic tank will be solidified. The septic tank and its contents will be removed and disposed as hydrocarbon waste. The distribution box and a 10 -foot section of associated piping will be removed and disposed as construction debris. The ends of any remaining piping will be sealed. The excavations will be backfilled. This CAS is not in a posted area.

\section{CAS 03-59-02, Building 3C-45 Septic System}

This site is located in Area 3 north of Road 3-01 and west of Angle Road. The site includes a 1,200-gallon concrete septic tank containing approximately 714 gallons of liquid and solid waste, a distribution box, a leachfield, two dry wells, and associated piping. TPH at concentrations of up to 28,000 milligrams/kilogram, VOCs at concentrations above the TCLP regulatory levels for hazardous waste, and elevated levels of gross alpha and beta radiation are present in the septic tank.

The liquid and solid contents of the septic tank will be sampled for hazardous and radioactive constituents for waste handling determination. The septic tank and its contents will be removed and properly disposed depending on waste characterization sample results. If the contents are determined to be hazardous or mixed waste, they will be removed from the tank and disposed. If the contents are below regulatory limits for hazardous waste, they will be solidified either in a solidification basin or in the septic tank. The distribution box will be removed and disposed as construction debris, and the ends of any remaining piping will be sealed. The dry well north of the leachfield will be excavated to 12 feet below ground surface, and the dry well east of the building foundation will be excavated to 10 feet below ground surface. Material removed from the dry well will be disposed as sanitary waste. The excavations will be backfilled. This CAS is not in a posted area.

\section{CAS 06-51-01, Sump and Piping}

This site is located in the Area 6 Well 3 Yard. The site includes a sump and associated piping running to a collection box. TPH is present in the pipe running between the collection box and the sump at concentrations up to 220 milligrams/kilogram.

Approximately 82 feet of piping and the sump will be removed and disposed as hydrocarbon waste. The ends of any remaining piping will be sealed. The excavation will be backfilled. This CAS is not in a posted area. 


\section{CAS 06-51-03, Clean-Out Box and Piping}

This site is located in the Area 6 Well 3 Yard. The site includes a clean-out box and piping. TPH is present in the soil in the clean-out box at concentrations up to 180 milligrams/kilogram.

The clean-out box, approximately 0.5 cubic yards of soil from the clean-out box, and approximately 25 feet of piping will be removed and disposed as hydrocarbon waste. The ends of any remaining piping will be sealed. The excavation will be backfilled. This CAS is not in a posted area.

\section{Environmental Considerations}

\section{Waste}

1. Non-Rad Solid Waste: Non-Rad Solid Waste (e.g., non-impacted personal protective equipment and general trash) and construction debris (e.g., non-impacted septic system components) removed from sites will be screened for free release and disposed in an onsite landfill. Hydrocarbon waste will be transported to the Area 6 Hydrocarbon Landfill for disposal.

2. Hazardous Waste: Hazardous Waste may be generated at CAS 03-59-02 in the form of VOCcontaminated septic tank contents. The hazardous waste will be managed and disposed according to all applicable BN procedures and state and federal regulations. Upon generation, the waste shall be containerized and stored in a satellite accumulation area or a 90-Day Hazardous Waste Accumulation Area depending on the amount of waste generated. After an approved waste profile is generated, the waste will be shipped to an appropriate offsite facility.

3. Low-Level Rad Waste: Low-Level Rad Waste may be generated at CAS 03-59-02. Characterization samples indicated that the septic tank contents contain gross alpha and gross beta radioactive contamination. If waste characterization results indicate that the septic system contents at this site should be handled as low-level rad waste, the waste will be disposed according to all applicable $\mathrm{BN}$ procedures and state and federal regulations.

4. Mixed Waste: Mixed Waste may be generated at CAS 03-59-02. Characterization samples indicated that the septic tank contents contain levels of VOCs and alpha and beta contamination that are above landfill limits. If waste characterization results indicate that the septic system contents at this site should be handled as mixed waste, the waste will be disposed according to all applicable $\mathrm{BN}$ procedures and state and federal regulations.

6. Wastewater: Heavy equipment will be decontaminated, as necessary, prior to release from the site. A decontamination pad will be constructed by lining a bermed area large enough to hold the equipment. The equipment will be cleaned on the pad using a pressure washer/steam cleaner or rinsed. Rinsate will be mixed with clean fill and solidified or allowed to evaporate. All rinsate, after solidification, will be characterized by sampling, and properly disposed. The liner will be disposed in the appropriate disposal facility.

\section{Hazardous Materials}

1. Petroleum/Fuel (storage/use): Heavy equipment onsite will use petroleum fuel. No fuel will be stored onsite outside of the equipment. Absorbent pads will be used if equipment appears to be leaking petroleum.

6. Radioactive Materials: Characterization samples at CAS 03-59-02 indicated elevated levels of alpha and beta radiation present in septic tank contents. The soil will be managed as mixed waste until a waste profile is generated. 


\section{Air Emissions}

2. Dust/Particulate Matter: Dust/Particulate Matter will be controlled during soil excavation by the use of water sprays.

\section{Site Location/Other}

1. Environmental Restoration Site: These sites are included in the Federal Facility Agreement and Consent Order between the Department of Energy and the state of Nevada as part of CAU 516.

2. Excavation/Land Surface Disturbance: Excavation will occur at the four CASs to remove septic systems. A utility survey and blind penetration/excavation permit will be completed prior to excavation. All excavations will be backfilled with clean fill from an approved borrow source and contoured to the surrounding grade.

8. Unexploded Ordnance Area: UXO may be encountered at the sites in CAU 516. If UXO is encountered, the appropriate notifications will be made, and all BN procedures will be followed.

9. Noise: Elevated noise levels may result from the operation of backhoe and/or loader equipment. Personnel not directly involved with operation of this equipment will be kept back at least 15 feet while equipment is in use. The equipment operator will follow the instructions as directed in the Site Specific Health and Safety Plan. 
Revision: 0

Date: April 2007

\section{LIBRARY DISTRIBUTION LIST}


CAU 516 Closure Report

Section: Library Distribution List

Revision: 0

Date: April 2007

THIS PAGE INTENTIONALLY LEFT BLANK 


\section{LIBRARY DISTRIBUTION LIST}

U.S. Department of Energy

National Nuclear Security Administration

Nevada Site Office

Technical Library

P.O. Box 98518, M/S 505

Las Vegas, NV 89193-8518

U.S. Department of Energy

National Nuclear Security Administration

Nevada Site Office

Public Reading Facility

c/o Nuclear Testing Archive

P.O. Box 98521, M/S 400

Las Vegas, NV 89193-8521

U.S. Department of Energy

Office of Scientific and Technical Information

P.O. Box 62

Oak Ridge, TN 37831-0062
$1 \mathrm{CD}$ (uncontrolled)

1 CD (uncontrolled)

1 electronic copy (uncontrolled) 
CAU 516 Closure Report

Section: Library Distribution List

Revision: 0

Date: April 2007

THIS PAGE INTENTIONALLY LEFT BLANK 